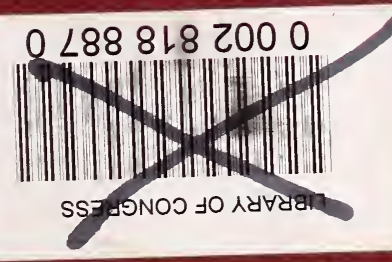




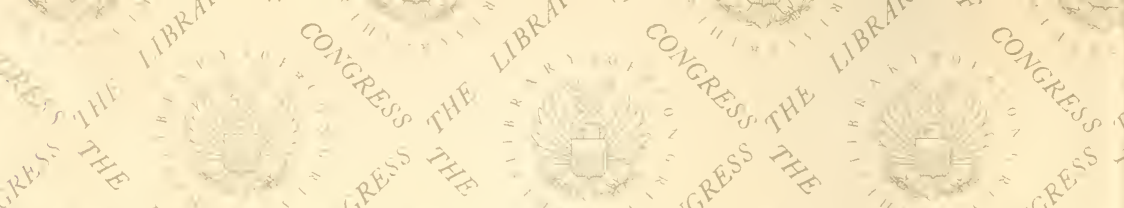

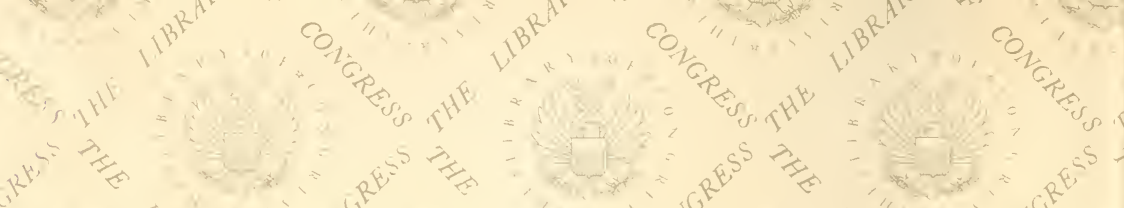

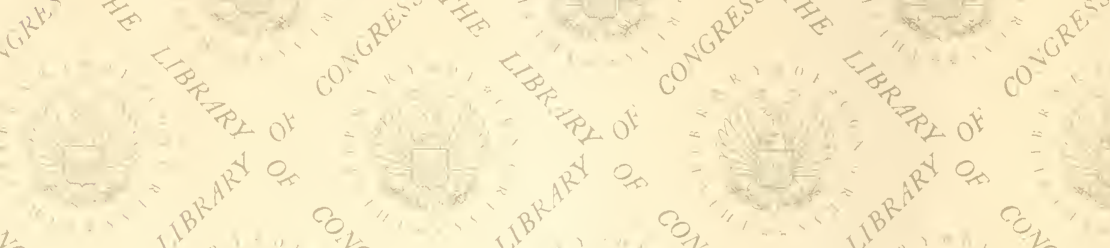
$\hat{P}_{p_{0}}$

(ut)<smiles>c1ccccc1</smiles><smiles>C1CC1C1CC1</smiles>

$=-\pi_{2}, 0$

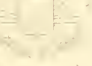

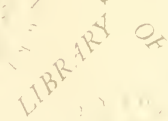

cos

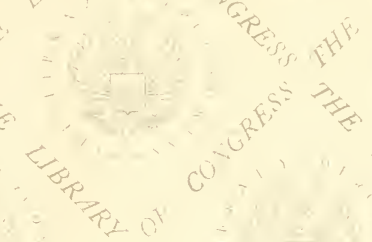

to

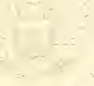<smiles>C1#CCC=C1</smiles>

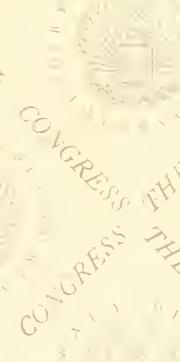

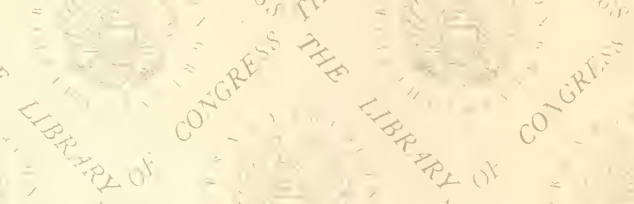
$\mathrm{CO}^{\mathrm{O}^{-}}$

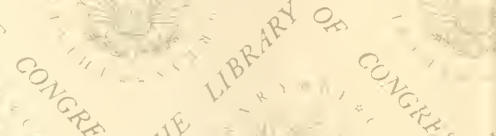<smiles>[CH]1CC1</smiles>

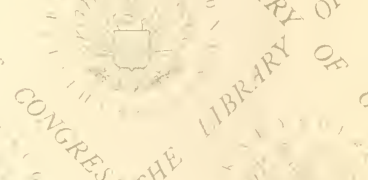
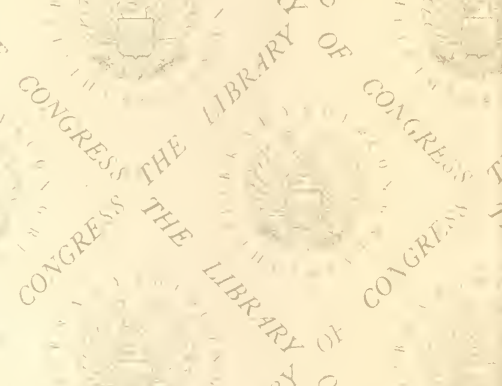

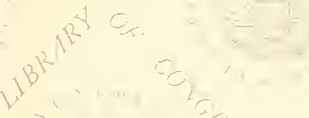
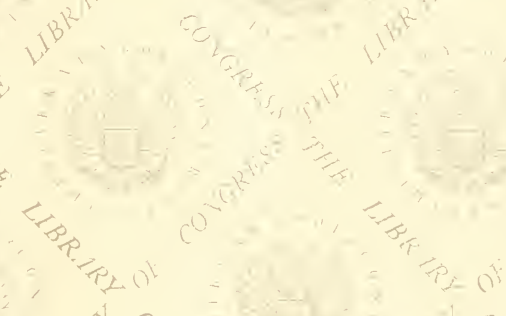

is

W 20

(18)<smiles>C1CC2C3CCC(C3)[C@H]2C1</smiles><smiles>CC1CCCC1</smiles><smiles>[CH]1CCCC1</smiles>

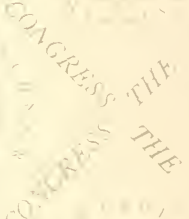<smiles>C1CC1</smiles><smiles>[C]1[CH]CC1</smiles>

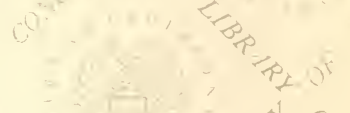<smiles>CCCC1(CC)CCCC1</smiles>

is

$p_{p}$

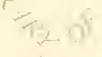<smiles>C1CCCC1</smiles> 


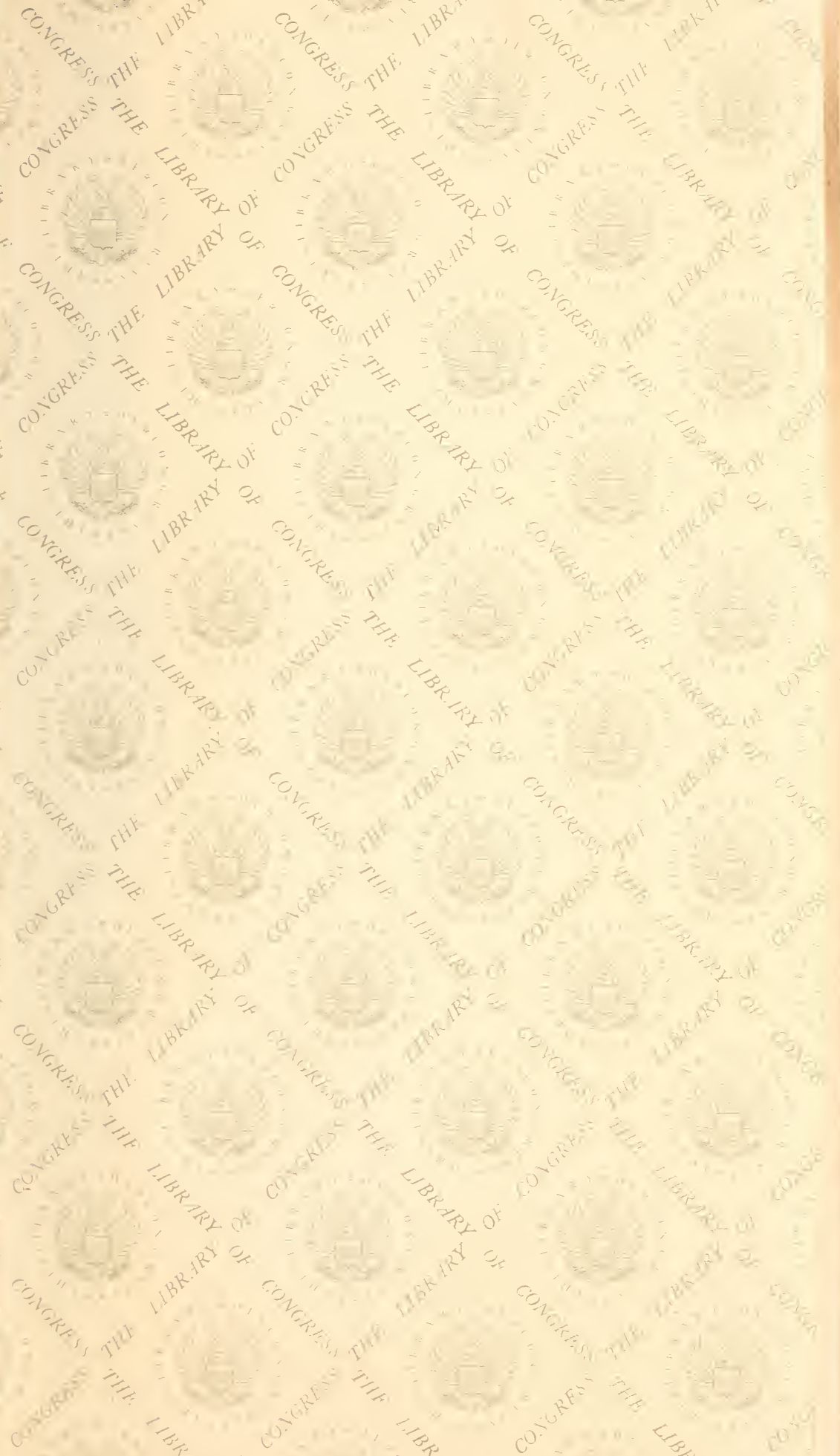








\section{S Y L VA N S E T CHES;}

OR,

\section{A COMPANION}

To

\section{THE PARK AND THE SHRUBBERY :}

W 1 T H

ILLUSTRATIONS FROM THE WORKS OF THE POETS.

BY THE AUTHOR OF THE

\section{FLOR A DOMESTICA.}

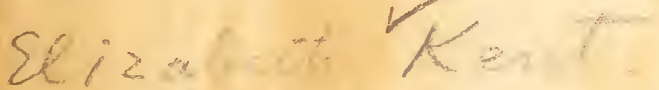

if

"And he spake of Trees, from the cedar-tree that is in Lebanon, even unto the hyssop that springeth up out of the wall."

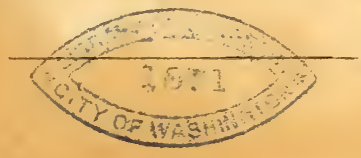

\section{O N D O N :}

PRINTED FOR WHITTAKER, TREACHER, AND CO. A VE-MARIA-LANE. 


$$
5 x^{38^{2}}+3
$$




\section{HER ABSENT SISTER,}

\section{THIS VOLUME}

IS AFFECTIONATELY INSCRIBED

- BY

THE WRITER. 



\section{IS'T OF THE PLA N T}

DESCRIBED IN THIS WORK.

A.

Acacia ............ Gledítsia Triacánthos..... see Robinia ..................... 347 Agnus Castus ......... Vítex Agnus Castus ...... 4

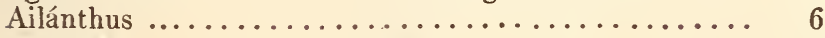
Alaternus . . . . . . . . . Rhámnus Alatérnus...... 7 Alder .............. Alnus ........... 8 Alder Buckthorn ........ Rhámnus Frángula ....... 13 Alexandrian Laurel ...... Rúscus Racemósus ....... 14 A'rbutus .......................... 15 Ash-tree .......... Fráxinus ........... 20 Aspen ........... Pópulus Trémula....... 30

B.

Barberry-bush.........érberis .......... 35

Beech-tree ......... Fágus Sylváticus....... 38

Birch-tree .......... Bétula ........... 45

Bird Cherry .......... Prúnus ........... 51

Boxthorn .......... Lýcium ........... 53

Bladdernut-tree ....... Staphyléa .......... 54

Bramble ........... Rúbus ............. 56

Butcher's Brooin ...... Rúscus............ 61

Button-wood ......... Cephalánthus ....... 63

C.

Carob-tree ......... Ceratónia Silíqua....... 64 Carolina Allspice ...... Calycánthus Flóridus ..... 66 


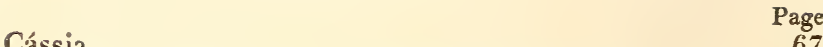

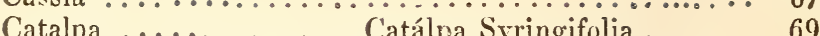

C'edar ............ Pinus Cédrus ........ 70

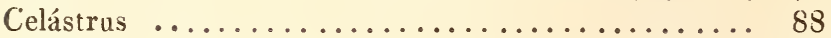

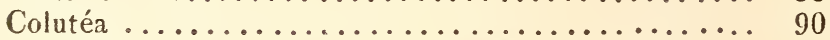

Chestnut-tree ........ Castánea Vésca ....... 92

Cornel-tree .......... Córnus ............ 104

Cypress ........... Cupréssus .......... 109

E.

Elder-tree ........... Sambúcus .......... 124

Elm-tree ............ U'Imus . . . . . . . . . . 129

F.

Fir-tree .......... Pinus ........... 141

(;.

Glýcine ...................... 149

H.

Hare's-ear .......... Bupléurum ......... 150

Hawthorn.......... Cratæ'gus .......... 151

Hazel Nut-tree........ Córylus ........... 156

Holly-bush ......... I'lex ............ 164

Hornbeain-tree........ Carpínus ......... 170

Horse Chestuut-tree..... E'sculus .......... 175

I.

I'tea............. I'tea Virgínica ........ 180

Iry-bush .......... Hédera Hélix ........ 181

Judas-tree .......... Cércis ............. 190

Juniper-bush ........Juníperus........... 192

L.

Larch-tree . . . . . . . Pínus Lárix . . . . . . . 201

Laurel ............. Prúnus Laurocérasus ..... 210

Laurustinus . . . . . . . Vibúrnum T'́nus . . . . . . 213

Lime-tree.......... Tília ............. 216

Liquidamber-tree...... Liquidámbar......... 224

M.

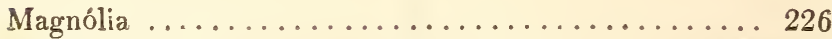

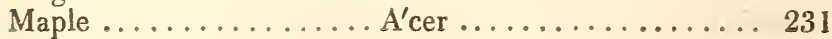

Medlar ............. Méspilus .......... 245 
Page

Mountain Ash ........ Pýrus Aucupária ........ 248

Mulberry-tree ......... Mórus ............. 254

Myríca.............................264

N.

Nettle-tree ...........éltis ............. 268

New Jersey Tea-tree ... Ceanóthus Americánus... . 273

O.

Oak-tree ........... Quércus ........... 274

P.

Phillyréa ............................ 303

Pine-tree ........... Pínus ............. 304

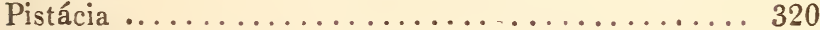

Plane tree ........... Plátanus ............ 327

Pomegranate-tree ....... Púnica Granátum ....... 333

Poplar-tree .......... Pópulus ............ 338

Pseudo Acacia ......... Robínia ............. 347

Pyracantha .......... Cratæ'yus Pyracántha ..... 349

S.

Service-tree .......... Sórbus ........... . 350

Shrubby Syrian Mallow .. Hibíscus Syríacus ....... 352

Spindle-tree......... Euónymus ......... 35.3

Sumach ........... Rhus ............ 355

T.

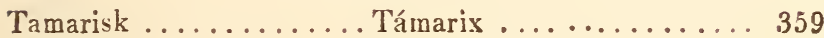

Trumpet-flower ........ Bignónia ........... 361

Tulip-tree .......... Liriodéndrum ........ 366

Tupelo-tree ........ Nýssa . . . . . . . . . . 369

W.

Walnut-tree ......... Júglans ........... 371

Wayfaring-tree. . . . . . . . Vibúrnum Lantána . . . . . . 391

Whitebeam-tree ... . . . Fýrus A'ria .......... . 382

Widow-wail .......... Cneórum 'Tricóccum ..... 383

Wild Cherry-tree ....... Prúnus A'rium ... . . . . . 384

Willow-tree .......... Sálix ............ 386

Y.

Yew-tree ......... Táxus Baccáta........ 396 



\section{PREFACE.}

As the intention of this volume is to give an unceremonious introduction of certain trees and shrubs to our readers, who are occasionally in the habit of meeting them without being acquainted, in many instances, even with their names, botanical language has been carefully avoided; for although it would often have saved many words, it was considered that such terms would be intelligible only to the botanist, and that the botanist was precisely the last person to whom a description of common trees or shrubs would be likely to be of any use. One word only, as far as the writer remembers, has been introduced from the botanical vocabulary - the word pirnate; and this occurs so often, and requires so much circumlocution to 
aroid, that it has been used: but an explanation has been giren of this term, for those to whom it is not familiar, in the rery first article in the rolume, the Acacia.

It has been obserred, and objected against the mriter, that, in a former publication, of a similar nature to the present, there was wanting a spirit of religion, and that frequency of grateful reference to the Creator, which would seem naturally to flow from a contemplation of the ronders and beauties of creation. As some conjectures, likely to be injurious to her, hare been formed with regard to the cause of this omission, and as the same remark may, with equal justice, be made upon the present rolume, she feels it necessary to say a few words upon this subject.

That she has not introduced the subject of religion, is certainly true: but she thinks it can scarcely be said with justice, that any book is wanting in a spirit of religion which treats of the beauties of nature and of the pleasures to be derired from them. It is natural to us all to feel grateful towards those by whose means we enjoy any portion 
of comfort or pleasure. The infant who receives its first sustenance from the bosom of its mother will smile in her face, and hold out its little arms towards her with the most ecstatic delight, when it has ceased to expect that nourishment. Children will always regard those kindly who are kind to them; and is it to be supposed that the great and manifold blessings of heaven should fail to excite the gratitude of man? In speaking of the beauties and properties of created things, we speak of the beneficence of the Creator; and in recalling to the minds of men the pleasures to be derived from them, we awaken a grateful sense of the source from whence they flow. However men differ in the forms of religion, its essence is still the same; and many who would listen without emotion to volumes of religious admonition, will feel their hearts glow with grateful admiration when they walk abroad in the sunshine.

If a man stand upon a rising ground, and look abroad upon a fertile country, must he be told the source of all that beauty? must he be reminded what he ought to feel before his heart will swell 
with a fulness of gratitude and love? Oh! surely not; for

"What he finds

Of flavour or of scent in fruit or flower, Or what he views of beautiful or grand In nature, from the broad majestic oak To the green blade that twinkles in the sun, Prompts with remembrance of a present God."

CowPER.

Tell a child that he should love and be grateful to a kind mother for her care of him, and he will understand it to be right and just; but if she amuse him, and make him happy in health, or soothe and nurse him tenderly in sickness, he will feel it to be inevitable.

It has been observed, that no one can pursue the study of anatomy without being struck with admiration of the design and infinite variety of purpose displayed in the construction of the human frame: the same may be said of the humblest weed.

Of all the productions of nature, the vegetable world is surely the most important to the wellbeing of man, and the source of his purest pleasures. 
Some trees appear to supply every necessary of life to the inhabitants of the countries where they grow; such are the Birch and the Fir to the inhabitants of Lapland, Sweden, and Norway; the Lime to the peasants of Russia ; such is the Aloe in America, the Palm in Asia.

"The more we study vegetable chemistry in the torrid zone," says Humboldt, " the more we shall discover in some remote spot, but attainable by the trade of Europe, and half-prepared in the organs of plants, products that we believe belong only to the animal kingdom, or which we obtain by processes of art, which, though sure, are often tedious and difficult*."

He instances the wax afforded by one of the Palms, silk by another, and the nourishing milk of the Palo de vaca, the Butter-tree of Africa. Wax is obtained from other plants, as some species of the Myrica; and tallow from the Tallow-tree (Croton sebiferum). Many others might be mentioned. Some authors have spoken facetiously of Shirt-trees, and Cap-trees. "We saw on the slope

* Humboldt's Personal Narrative, vol. v. p. 286. 
of the Cerra Duida," says Humboldt, "Shirt-trees fifty feet high. The Indians cut off cylindrical pieces two feet in diameter, from which they peel the red and fibrous bark, without making any longitudinal incision. This bark affords them a sort of garment, which resembles sacks of a very coarse texture, and without a seam. The upper opening admits the head, and two lateral holes are cut to admit the arms*." The Cap-tree is a species of Palm-tree, of which the spathe furnishes a kind of pointed cap, resembling coarse net-work $\uparrow$. Strabo observes of the Cocoa Palm, that it is fit for three hundred and sixty uses. "It affords wine," says Evelyn, "bread, milk, oil, sugar, vinegar, thread, cloth, caps, dishes, spoons, and other vessels and utensils, baskets, mats, umbrellas, paper, brooms, ropes, sails, and almost all that belongs to the rigging of ships + ."

Humboldt remarks, that "it is curious to observe, in the lowest degree of human civilization, the existence of a whole tribe depending on a

\footnotetext{
* Humboldt's Personal Narrative, vol. v. p. 546.

+ Ibid. vol. iv. p. 226

‡ Evelyn's Sylva.
} 
single species of Palm-tree, similar to those insects which feed on one and the same flower, or on one and the same part of a plant*."

To attempt to enumerate the uses of vegetable productions were to enter upon an endless theme indeed; as vain would it be to attempt to describe their beauties; but there is something beyond mere use, something beyond mere beauty, in their influence upon the human mind;-there is something in flowers and trees which excites our kindest sympathies, which soothes our keenest sorrows. "All intelligent persons have embraced the solace of shady groves," says Evelyn; " and all devout persons have found how naturally they dispose our spirits to religious contemplation."

The animal, or the mineral, can no more compare with the vegetable kingdom in the pleasure it affords to man, than in its importance in supplying him with the necessaries of life. Minerals are, no doubt, of great and important service to mankind; and animals afford them pleasure, though it is to be feared the greatest is the delight they take in

* Evelỵn's Sylva, vol. v. p. 729. 
seeking their destruction, as in hunting, shooting, fishing, \&c.

A man may, indeed, love his horse or his dog, his monkey or his cat; may fondle a young tiger, or make a companion of a pet bear; but he will not lounge in a menagerie with his book, take a walk to Exeter Change to relieve his melancholy, or retire to his stable, or his dog-kennel, at twilight, to indulge in tranquil meditation. If he be weary, he will love to repose in the shade, upon the soft green grass ; if he be sad, he will love to wander in groves and woods; and, at the approach of sunset, he will doubly enjoy his book, his own thoughts, or the conversation of his friend, if he be seated under his favourite tree.

"Our groves were planted to console at noon The pensive wanderer in their shades."

Cowper.

Mrs. Radcliffe gives a natural picture of the pleasure a thoughtful and domestic man takes in his garden, and of the forcible manner (scarcely inferior to the power of music itself) in which old associations are revived by the sight of trees. The poet might with equal truth have written: 
"Should some tiee we used to love

In days of childhood meet our eye," \&c.

"Here, under the ample shade of a Plane-tree, that spread its majestic canopy towards the river, St. Aubert loved to sit, in the fine evenings of summer, with his wife and children, watching beneath its foliage the setting sun; the mild splendour of its light fading from the distant landscape till the shadows of twilight melted its various features into one tint of sober gray. Here, too, he loved to read and to converse with Madame St. Aubert, or to play with his children; resigning himself to the influence of those sweet affections which are ever attendant on simplicity and nature*."

His daughter is afterwards described as visiting this tree alone, for the first time, after an absence of some months, during which she had lost her father.

"Emily, wandering on, came to St. Aubert's favourite Plane-tree, where so often at this hour they had sat beneath the shade together, and, with her dear mother, so often had conversed on the

* Mysteries of Udolpho, vol. i. 
subject of a future state. How often, too, had her father expressed the comfort he derived from believing that they should meet in another world! Emily, overcome by these recollections, left the Plane-tree*."

There are several other passages on this subject, in the course of the same work.

Cowper speaks with great interest of the trees he remembered when a boy, though they were then already old: had he watched the progress of their growth from their first springing, they would have been yet dearer to him.

Claudian says of the old man of Verona,

" A neighbouring wood, born with himself, he sees, And loves his old cotemporary trees."

In old times, it was a custom with parents to plant a tree at the birth of a son, and to judge by the growth and thriving of the tree of the prosperity of the child. It is said in the life of Virgil, that the Poplar, planted on his birthday, far outstripped all its contemporariest.

* Mysteries of Udolpho, vol. i.

+ Evelyn's Sylva. 
Wordsworth speaks somewhere of the tenderness of feeling excited by trees and flowers, a tenderness which, in the absence of those we love, is often wasted on the senseless weed. It is a conviction of this kindly influence of nature that has emboldened the writer to bring the most opposite parties together amid these woody scenes; not hesitating even to place Mr. Southey by the side of Lord Byron, without fear of the consequences, but rather indulging a faint hope that they may shake hands and be friends before they return to the irritating bustle of towns and cities.

" The spleen is seldom felt where Flora reigns."

Who does not feel the truth of these beautiful lines of Coleridge?

"A green and silent spot, amid the hills, A small and silent dell! o'er stiller place No singing sky-lark ever poised himself. The hills are heathy, save that swelling slope, Which hath a gay and gorgeous covering on, All golden with the never bloomless furze, Which now blooms most profusely; but the dell, Bathed by the mist, is fresh and delicate As vernal corn-field, or the unripe flax, When, through its half-transparent stalks at eve, The level sunshine glimmers with green light.

b 2 
Oh! 'tis a quiet, spirit-healing nook! Which all, methinks, would lore; but chieft he, The humble man, who, in his youthful rears, Knew just so much of foll? as had made His early manhood more securely wise. Here he might lie on fern or withered heath, While from the singing lark (that sings unseen The minstrelsy that solitude lores best), And from the sun, and from the breez? air, Sweet influences trembled o'er his frame; And he, with many feelings, many thoughts, Made up a meditative jor, and found Religious meanings in the forms of nature! And so, his senses graduall! wrapt In a half sleep, he dreams of better worlds, And, dreaming, hears thee still, O singing lark, That singest like an angel in the clouds."

Cowley, who was an enthusiastic lover of the country, and took great delight in his garden, exclaims :

"Who that has reason and his smell,

Would not among roses and jasmine dwell,

Rather than all his spirits choke

With exhalations of dirt and smoke, And all th' uncleanness which does drown In pestilential clouds a populous town?"

Spenser has pictured some spots so lorely, that nature herself could scarcely excel them : we must indulge in one or two of them: will the reader have any objection to accompany us? 
"Fresh shadows, fit to shroud from sunny ray;

Fair lawnds, to take the sun in season due;

Sweet springs in which a thousand nymphs did play;

Soft rumbling brooks that gentle slumber drew;

High-reared mounts, the lands about to view ;

Low-looking dales, disloigned from common gaze;

Delightful bowers, to solace lovers true ;

False labyrinths fond runners' eyes to daze :

All which by Nature made, did Nature's self amaze.

And all without were walks and alleys dight

With divers trees, enranged in even ranks;

And here and there were pleasant arbors pight,

And shady seats, and sundry flow'ring banks,

To sit and rest the walker's weary shanks."

If the reader feel at all fatigued, we will leave him here to rest his "weary shanks," while we proceed a little further with the poet.

How beautiful is that passage beginning -

" There the most dainty paradise on ground

Itself doth offer to his sober eye,

In which all pleasures plenteously abound,

And none does other's happiness envy:

The painted flowers, the trees upshooting high, The dales for shade, the hills for breathing space, The trembling groves, the crystal running by;

And that which all fair works doth most aggrace, The art which all that wrought appeared in no place." 
We should be tempted to dwell longer here, but as we have further to go, we will not linger, but set sail for yon little island:

"It was a chosen plot of fertile land Emongst wide waves set like a little nest, As if it had by Nature's cunning hand Been choicely picked out from all the rest, And laid forth for ensample of the best:

No dainty flower or herb that grows on ground, No arboret with painted blossoms dress'd, And smelling sweet, but there it might be found To bud out fair, and throw her sweet smells all around.

No tree whose branches did not bravely spring;

No branch whereon a fine bird did not sit;

No bird but did her shrill notes sweetly sing;

No song but did contain a lovely dit."

A wood or a grove would seem imperfectly represented if it were not loud with music: the cheerful notes of birds joying in the sunshine are always enlivening, and they have been repaid by the poets with immortal honours. Spenser conveys the wounded squire to such a charming place, that he could scarcely need any other cure than to dwell there:

"Into that forest far they thence him led, Where was their dwelling, in a pleasant glade, 
With mountains round about environed, And mighty woods, which did the valley shade, And like a stately theatre it made, Spreading itself into a spacious plain ; And in the midst a little river played Emongst the pumy stones, which seemed to 'plain With gentle murmur that his course they did restrain.

Beside the same a dainty place there lay, Planted with myrtle-trees, and laurels green, In which the birds sung many a lovely lay Of God's high praise, and of their love's sweet teen, As it an earthly paradise had been:

In whose enclosed shadow there was pight A fair pavilion, scarcely to be seen, The which was all within most richly dight, That greatest princes living it mote well delight.

Thither they brought that wounded squire, and laid In easy couch, his feeble limbs to rest."

Tasso has some beautiful passages of this kind in his Jerusalem Delivered :

"V'è l'aura molle, e'l ciel sereno, e lieti

Gli alberi e i prati, e pure e dolci l'onde, Ove fra gli amenissimi mirteti

Sorge una fonte, e un fiumicel diffonde.

Piovono in grembo all' erbe i sonni queti

Con un soave mormorio di fronde;

Cantan gli augelli : i marmi io taccio e l'oro, Maravigliosi d'arte e di lavoro."

Canto $\mathrm{x}$. 
"For there, in thickest shade of myrtles fair, A crystal spring pour'd out a silver flood Amid the herbs, the grass, and flowers rare; The falling leares down patter'd from the wood; The birds sang hymins of love ; ret speak I nought Of gold and marble rich, and richly wrought." Farrfax's Translation.

Another charming passage there is in this poem, which Spenser has imitated in the twelfth canto of his second book:

"Vezzosi angelli, infra le verdi fronde, Temprano a prova lascirette note;

Normora l'aura, e fa le foglie e l'onde Garrir, che variamente ella percote Quando taccion gli augelli, alto risponde; Quando cantan gli augei, piu lieve scote. Sia caso o d'arte, or accompagna, ed ora Alterna i versi lor la musica ora."

Canto xvi.

"The joyous birds, hid under greenwood shade, Sung merry notes on every branch and bough; The wind, that in the leares and waters played, With murmurs sweet now sung, and whistled now ; Ceased the birds, the winds loud answer made, And while they sang, it rumbled soft and low; Thus, were it hap or cunning, chance or art, The wind in this strange music bore its part."

Farrfax's Translation.

The beauties of the different seasons, particularly 
of the spring and autumn, have frequently employed the poet's pen :

" MIoist, bright, and green, the landscape laughs around.

Full swell the woods; their every music wakes,

Mix'd in wild concert, with the warbling brooks

Increased, the distant bleatings of the hills,

And hollow lows responsive from the vales;

Whence, blending all, the sweeten'd zephyr sings.

Then spring the living herbs, profusely wild, O'er all the deep green earth, beyond the power Of botanist to number up their tribes: Whether he steals along the lonely dale In silent search, or through the forest, rank With what the dull incurious weeds account, Bursts his blind way; or climbs the mountain-rock, Fired by the nodding verdure of its brow : With such a liberal hand has nature flung Their seeds abroad, blown them about in winds Innumerous, mix'd them with the nursing mould, The moistening current, and prolific rain."

Thomson.

Gawin Douglas has a lively description of the spring, which has been modernized by $\mathrm{Mr}$. Fawkes. It is addressed to May, upon whom the beauties of spring are frequently lavished by the English poet. The poets of France and Italy more frequently bestow them upon April, who 
shows a more pleasant aspect and amiable disposition towards them than she does in this country.

The young and joyous spirit of spring sheds its sweet influence upon every thing: the streams sparkle and ripple in the noon-day sun, and the birds carol tipseyly their merriest ditties. It is surely the loveliest season of the year! Yet, hold! summer follows; and how beautiful is summer! the trees are heavy with fruit and foliage; the sun is bright and cheering in the morning; the shade of broad and leafy boughs is refreshing at noon; and the calm breezes of the evening whisper gently through the leaves, which reflect the liquid light of the moon, when she is seen

' lifting her silver rim

Above a cloud, and with a gradual swim

Coming into the blue with all her light."

And autumn-some will not hesitate to say that spring itself must yield to russet autumn. Yet one advantage has spring, in being the herald of the year's ripe beauties; whereas autumn is daily warning us of the approach of the chill blasts of winter; and winter, it must be confessed, is the 
least beauteous of the seasons, though for many of our home-loving countrymen, it has, perhaps, more comfort: than any other season. Philips expatiates warmly upon the fantastic freaks of winter's frost, in his Letter from Copenhagen :

"And yet but lately have I seen, even here, The winter in a lovely dress appear.

Ere yet the clouds let fall the treasured snow, Or winds began through hazy skies to blow, At ev'ning a keen eastern breeze arose, And the descending rain unsullied froze.

Soon as the silent shades of night withdrew, The ruddy morn disclosed at once to view The face of nature in a rich disguise, And brightened every object to my eyes : For every shrub, and every blade of grass, And every pointed thorn, seemed wrought in glass; In pearls and rubies rich the hawthorns show, While through the ice the crimson berries glow; The thick-sprung reeds which watery marshes yield Seem polished lances in a hostile field; The stag, in limpid currents, with surprise, Sees crystal branches on his forehead rise; The spreading oak, the beech, and towering pine, Glazed over, in the freezing æther shine; The frighted birds the rattling branches shun, Which wave and glitter in the distant sun: When if a sudden gust of wind arise, The brittle forest into atoms flies; The crackling wood beneath the tempest bends, And in a spangled shower the prospect ends." 
The following lines upon winter, addressed to the memory of Mr. Thomas Philips, would apply to the writer of this celebrated winter-piece:

"Nor were his pleasures unimproved by thee: Pleasures he has, though horribly deform'd: The silver'd hill, the polish'd lake, we see, Is by thy genius fix'd, preserved, and warm'd."

Chatterton.

The foliage of the wood begins in early summer to exhibit a variety of hues; greens infinitely varied; but the rich though sober dress of autumn is diversified also with yellow, brown, and red.

" But see, the fading many-coloured woods, Shade deepening over shade, the country round Imbrown; a crowded umbrage, dusk and dun, Of every hue from wan declining green To sooty dark. These now the lonesome Muse, Low-whispering, lead into their leaf-strown walks, And give the season in its latest view.

* * * * * * *

Now the leaf

Incessant rustles from the mournful grove; Oft startling such as, studious, walk below, And slowly circles through the waving air."

Thomson's Autumn.

"So when derne Autumn, wyth hys sallowe hande, Tares the green mantle from the lymed trees, The leaves bespringed on the yellow strande Flie in whole armies from the blataunte breeze."

Chatterton. 


\section{Chatterton poetically describes autumn as}

"Wyth hys goulde honde guylteynge the falleynge lefe."

Many writers have touched upon the difference in the colours of trees:

"Nor less attractive is the woodland scene, Diversified with trees of every growth, Alike, yet various. Here the gray smooth trunks Of ash, or lime, or beech, distinctly shine Within the twilight of their distant shades; 'There, lost behind a rising ground, the wood Seems sunk, and shortened to its topmost boughs. No tree in all the grove but has its charms, Though each its hue peculiar, paler some, And of a wannish gray; the willow such, And poplar that with silver lines his leaf, And ash, far-stretching his umbrageous arm ; Of deeper green the elm; and deeper still, Lord of the woods, the long-surviving oak. Some glossy leaved, and shining in the sun, The maple, and the beech of oily nuts Prolific, and the lime at dewy eve Diffusing odours: nor unnoted pass The sycamore, capricious in attire, Now green, now tawny, and ere autumn yet Have changed the woods, in scarlet honours bright."

Cowper.

Surely the poet takes some licence, in calling the Poplar blue:

"Below me trees unnumber'd rise, Beautiful in various dyes : 
The gloomy pine, the poplar blue, 'The yellow beech, the sable yew, The slender fir that taper grows, The sturdy oak with broad-spread boughs."

\section{DYeR's Grongar Hill.}

"Here rise no cliffs the vale to shade, But, skirting every sunny glade, In fair variety of green, The woodland lends its sylvan screen. Hoary, yet haughty, frowns the oak, Its boughs by weight of ages broke; And towers erect in sable spire The pine-tree, scathed by lightning fire ; The drooping ash and birch between Hang their fair tresses o'er the green ; And all beneath at random grow Each coppice dwarf of varied show; Or round the stems profusely twin'd, Fling summer odours on the wind."

Prior represents Solomon seeking knowledge of the learned, at once confessing his ignorance on subjects he is supposed to understand, and expressing his desire to be informed :

"The vegetable world, each plant and tree, Its seed, its name, its nature, its degree, I am allowed, as Fame reports, to know, From the fair cedar on the craggy brow Of Lebanon, nodding supremely tall, To creeping moss, and hyssop on the wall: Yet, just and conscious to myself, I find A thousand doubts oppose the searching mind. 
I know not why the beech delights the glade With boughs extended, and a rounder shade, Whilst towering hirs in conic forms arise, And with a pointed spear divide the skies; Nor why again the changing oak should shed The yearly honour of his stately head; Whilst the distinguish'd yew is ever seen, Unchanged his branch, and permanent his green. Wanting the sun, why does the caltha fade? Why does the cypress flourish in the shade? The tig, and date, why love they to remain In middle station, and an even plain, While in the lower marsh the gourd is found, And while the hill with olive shade is crown'd ? Why does one climate and one soil endue The blushing poppy with a crimson hue, Yet leave the lily pale, and tinge the violet blue? Why does the fond carnation love to shoot

$A$ various colour from one parent root; While the fantastic tulip strives to break In twofold beauty and a parted streak; The twining jasmine, and the blushing rose, With lavish grace their morning scents disclose; The smelling tuberose and jonquil declare The stronger impulse of an evening air? Whence has the tree (resolve me), or the flower, $A$ various instinct, or a different power?

Why should one earth, one clime, one stream, one breath, Raise this to strength, and sicken that to death?

Whence dces it happen that the plant which well We name the sensitive, should move and feel?

Whence know her leaves to answer her command, And with quick horror fly the approaching hand ?" 
The learned could not answer these inquiries; neither could they have explained why certain plants are so choice in the selection of their friends, that they will turn from such as do not please them. We cannot suppose this to be without reason: plants are too amiable to indulge in causeless antipathies.

"On pretend encore," says the Abbé Barthelemy, "que certains arbres ont une influence marquée sur d'autres arbres; que les oliviers se plaisent dans le voisinage des grenadiers sauvages, et les grenadiers des jardins dans celui des myrtes *."

"They say, too, that certain trees have a marked influence on others; that olive trees delight in the neighbourhood of the wild pomegranate, and that garden pomegranates delight in that of myrtles."

\section{"Everlasting hate}

The vine to ivy bears, nor less abhors

The colewort's rankness; but with amorous twine

Clasps the tall elm: the Postan rose unfolds

Her bud more lovely near the fetid leek

(Crest of stout Britons), and enhances thence

The price of her celestial scent: the gourd

And thirsty cucumber, when they perceive

'Th' approaching olive, with resentment fiy

Her fatty fibres, and with tendrils creep

Diverse, detesting contact; whilst the fig

* Voyage d'Anacharsis, vol. v. p. 30. 
Contemns not rue, nor sage's humble leaf, Close neighbouring: th' Herefordian plant Caresses freely the contiguous peach, Hazel, and weight-resisting palm, and likes ' $\mathrm{I}$ ' approach the quince, and the elder's pithy stem; Uneasy, seated by funereal yew, Or walnut (whose malignant touch impairs All generous fruits), or near the bitter dews Of cherries."

J. Philips.

It is less a matter of surprise that men should not be able to explain these things, than that they should know so much as they do on these subjects; and that they should be able, in some instances, to improve upon nature herself.

"Et sæpe alterius ramos impune videmus

Vertere in alterius, mutatamque insita mala

Ferre pyrum, et prunis lapidosa rubescere corna.

* * * * * * * *

Inseritur verò ex fœetu nucis arbutus horrida, Et steriles platani malos gessere valentes, Castanea fagos, ornusque incanuit albo Flore pyri, glandemque sues fregere sub ulmis.

Nec modus inserere, atque oculos imponere simplex. Nam quà se medio tradunt de cortice gemmæ, Et tenues rumpunt tunicas, angustus in ipso Fit nodo sinus: huc aliena ex arbore germen Includunt, udóque docent inolescere libro. Aut rursum enodes trunci resecantur, et altè Finditur in solidum cuneis via; deinde feraces Plantæ immittuntur: nec longum tempus, et ingens 
Exiit ad cœlum ramis felicibus arbos, Miraturque novas frondes, et non sua poma."

VIrgil, Georgic ii.

"'Tis usual now an inmate graft to see With insolence invade a foreign tree:

Thus pears and quinces from the crab-tree come, And thus the ruddy cornel bears the plum.

* * * * * * *

The thin-leaved *arbute hazel-graffs receives, And planes huge apples bear, that bore but leaves. Thus mastful beech the bristly chestnut bears, And the wild ash is white with blooming pears, And greedy swine from grafted elms are fed With falling acorns, that on oaks are bred.

But various are the ways to change the state Of plants, to bud, to graff, t' inoculate. For where the tender rinds of trees disclose Their shooting gems, a swelling knot there grows; Just in that place a narrow slit we make, Then other buds from bearing trees we take; Inserted thus, the wounded rind we close, In whose moist womb th' admitted infant grows. But when the smoother bole from knots is free, We make a deep incision in the tree, And in the solid wood the slip enclose, The batt'ning bastard shoots again:and grows; And in short space the laden boughs arise, With happy fruit advancing to the skies.

* It is not easy to conjecture why the poet translates arbuta horrida, the thin-leaved arbutus: the leaves are not in themselves thin, neither is the tree scantily furnished with them. Martyn supposes the word horrida to signify the ruggedness of the bark. 
The mother plant admires the leaves unknown Of alien trees, and apples not her own."

Dryden's Translation.

The progress of the growth of plants is a very interesting subject, which Cowper has touched upon in an impressive manner in his Yardley Oak.

Milton has been uncivil enough to trace the intellect of man to vegetables.

"So from the roots

Springs lighter the green stalk, from thence the leaves

More airy, last the bright consummate flower

Spirits odorous breathes: flowers and their fruit,

Man's nourishment, by gradual scale sublimed,

To vital spirits aspire, to animal,

To intellectual; give both life and sense,

Fancy and understanding; whence the soul

Reason receives, and reason is her being,

Discursive or intuitive."

We have some individual trees of extraordinary magnitude, particularly Oak and Elm trees; but generally, the size of our trees bears no comparison with some described by travellers. The Palm trees are not in general remarkable for breadth, but some of them are of an extraordinary height : That which is called the Cabbage Palm, though scarcely two feet in diameter, will grow two hundred and fifty or three hundred feet high. On 
another, (which he calls the Seje Palm, Humboldt says he estimated the number of flowers on one raceme only, at forty-four thousand; and of the fruit produced thereby, at eight thousand. From this fruit, a beverage is obtained which tastes like milk of almonds, and is exceedingly nourishing. The Indian jugglers, he tells us, are paid by the people to go into the forests and sound the botuto, or sacred trumpet, under these trees, "to force the tree," as they say, "to yield an ample produce the following year*."

The Fan Palm, or Talipot tree, although the trunk is not particularly large, bears a leaf large enough to cover-twenty men. It will fold like a fan, and is then no bigger than a man's arm. The whole leaf, when spread out, is round; but, for use, it is cut into sections; these the people lay upon their heads, when they travel, with the point foremost, to cut their way through thickets. Soldiers carry them, not only to shade them from the sun, or keep them dry, in case of rain; but also to make tents to sleep under.

* Humboldt's Personal Narrative, vol. v. p. 152. 
A tree has been described as growing in China, of a size so prodigious, that one branch of it only will so completely cover two hundred sheep, that they cannot be perceived by those who approach the tree; and another so enormous, that eighty persons can scarcely embrace the trunk.

What a magnificent tree is the Banyan, or Indian Fig tree, or more properly we should say, forest! A tree of this kind has been described as 370 feet in diameter, the circumference of its shadow at noon measuring 1116 feet; and that of the several stems, of which there were fifty or sixty, 921 feet. There is a celebrated Banyan near Gombroon, on the Persian Gulf, and another near Fort St. David's, in the East Indies, which is computed to cover near $1 \% 00$ yards. "The Gentoos," says Martyn, "are almost as sensibly hurt if any one cuts or lops any of the branches, as if he had mutilated or destroyed a cow, which they hold in so much veneration." Thevenot speaks of it by the title of Var tree; he says it is also called Ber tree, and Arbre des racines (tree of roots,) and that it is held sacred by the Gentiles of India*. 
One of the species, under which it is said the god Vishnu was born, and which is thence held sacred to him, is named by Linnæus, religiosa.

The reader will remember Milton's celebrated description of the Indian Fig:

" The fig-tree, not that kind for fruit renowned, But such as at this day, to Indians known, In Malabar, or Deccan, spreads her arms, Branching so broad and long, that in the ground The bending twigs take root, and daughters grow About the mother tree, a pillared shade High over-arched, and echoing walks between."

The trunk of the Vine tree, which, as Evelyn observes, is "more like rope than timber, is, in a favourable soil, found as big as a man's body. A Vine furnished the doors of the cathedral at Ravenna, some of the planks of which measured twelve feet in length, and fifteen inches in breadth.

The Adansonia, or Ethiopian Sour Gourd, though not remarkably high, is of amazing bulk. The traveller from whom it takes its name measured several from sixty-five to seventy-eight feet in circumference, and describes the branches as from forty-five to fifty-five feet in length, and each branch large enough for a monstrous tree. The Bombax, or Silk Cotton tree, is one of the tallest 
trees of both Indies; the trunks are immense, and are hollowed into canoes. In the first voyage of Columbus, it is related that a canoe made of one of these trees, was seen at the island of Cuba, which was ninety-five palms in length, wide in proportion, and capable of containing one hundred and fifty men. It has been affirmed that some of these trees in the West Indies are too large to be embraced by sixteen men, and so high that an arrow cannot be shot to their top. Another traveller, speaking of some that he sav in Africa, asserts that twenty thousand men closely armed might, without inconvenience to one another, stand under the branches of one of them. Thevenot speaks of a tree in the island of Stanchio, of which he says, it has such a prodigious extent of shade, that it would easily cover two thousand men; that its branches are supported by stone columns and pillars of wood; that there are under it several shops, and benches to sit upon; and that the tree is like the Sycamore, except that the fruit resembles the chestnut, and serves to tan leather*.

* Thevenot's Voyage de Levant, Part I. p. 210. 
Asia, Africa, and America, abound with a variety of curious and interesting trees, not remarkable for size. Among others may be mentioned the Breadfruit tree, the fruit of which supplies the people with bread eight months in the year, only for the trouble of gathering it. The best kind is that which grows in Otaheite.

The Berticolletia excelsa, or Juvia of the Indians, which Humboldt describes as "one of the most majestic trees of the forests of the New World," is remarkable from the short space of time in which its fruit is formed. This fruit is known by a variety of names; as Nuts of the Amazon, Almonds of Peru, Almonds, or Chestnuts of Brazil, \&c. but their most usual name in this country is, Brazil Nuts. The nuts were known in Europe as early as the sixteenth century; but were supposed to grow on separate stalks. The tree which produces them is now better known, and it has been discovered that they grow, twenty or more together, in a shell as large as the human head. The nut itself is enclosed in a tolerably hard covering, yet the drupe or shell which contains them is half an inch thick, of very hard 
wood; and this fruit is formed in the space of fifty or sixty days.

The fruit falls to the ground, when ripe, with a prodigious noise; and it is thought dangerous to walk in the forests at that time, from the weight with which they fall from a height of fifty or sixty feet. A writer of the seventeenth century says, that no one could venture near them without corering his head and shoulders with a buckler of rery hard rood. Humboldt says these bucklers are not worn by the natives of Esmeralda, but that they spoke of the danger they incurred. The Indians celebrate the harvest of this fruit with dancing and excessive drinking*.

Mr. Humboldt did not see this fine tree in blossom, but understood that the blossoms were violetcoloured, and not produced till the tree was fifteen years old. The trunk is generally two or three feet in diameter, and the tree an hundred or an hundred and twenty feet high.

Independently of their own beauty, and of the pleasure men take in walking or sitting in their

* Humboldt's Personal Narrative, vol. v. p. 532, \&c. 
shade, trees may claim an interest with men of all tastes and professions. If a man be a soldier, he may remember trees which have sustained whole armies during a siege, which have concealed them from the observation of the enemy, and which have furnished them with fires when they had no snug chimney-corner at hand; if he be a lawyer, how many pounds have been poured into his pocket by litigation concerning woods, parks, and plantations; if he be a physician, he will know that much of his power to remove disease, and to restore health to man, is obtained from trees, from their roots, their bark, their gum, their leaves, their blossoms, their fruit, and their seeds.

Philosophers, and men of letters, will remember Plato's lectures to his disciples; the divine will think of the Olive branch, and will consider that Christ himself loved his garden, and sought the neighbourhood of trees, for meditation; and even the mere man of commerce will not think without pleasure of the profits of solid timber. As to poets, they always did love trees, and always will. " They thought of no other heaven," says Evelyn, 
speaking of the poets of ancient times, "on earth, or elsewhere ; for when Anchises was setting forth the felicity of the other life to his son, the most lively description he could make of it was to tell him

_L "Lucis habitamus opacis."

VIRGIL, Æin. vi.

"We dwell in shady groves."

And when Eneas had travelled far to find those happy abodes-

"Derenere locos lætos, et amœna vireta Fortunatum nemorum, sedesque beatas."

VirgiL, Æn. vi.

"They came to groves, of happy souls the rest, To evergreens, the dwellings of the blest."

The ancients would frequently sleep upon the leaves of some particular trees, which they supposed to have powers of inspiration; the Agnus-Castus was thought to compose the mind, and to bring true visions to the sleeper; and the Laurel was particularly efficacious in inspiring poetic fury. It might be well for some of our modern writers to 
sleep on such a bed. Not that any uncivil insinuations are intended: perhaps Apollo has, in the present age, a greater number of legitimate children than erer were known to live at the same time: but if already we have fine poets, such inspiration might produce Shakspeares. 


\section{SYLVAN SKETCHES.}

\section{A C A C I A.}

\section{GLEDITSIA.}

LEGUMINOS.x.

POLYGAMIA DIECIA.

The tree commonly called in this country the Acacia, is the Robinia, or Pseudo-acacia; but that here meant is the threethorned Acacia, or Honey-locust tree, botanically called Gleditsia triacanthos.-French, fevier.

The Gleditsia triacanthos, or Honey-locust tree, is a native of North America, remarkable for its brilliant green; the leaves are what the botanists term doubly pinnate, or bipinnate, having nine or ten pairs of small leaves, or leaflets, placed opposite, at certain distances, upon a common stalk, which forms the pinnate leaf: of these four or five pairs are placed, in the same regular manner, upon a second stalk, or midrib, - the whole, in botanical language, forming a bipinnate leaf. The flowers are small, and too nearly of the colour of the leaves to make any show; but the pod or legume which succeeds, being a foot or a foot and a half long, and of a dark brown colour, has a curious effect contrasted with the cheerful colour of the foliage.

The trunk is guarded with thorns three or four inches in length, having smaller ones coming out from their sides nearly at right angles; these are red, and have a very singular appearance. The branches also are armed with red thorns, proportionably smaller. 
The leaves of this tree, which spread open in fine weather, will droop at the approach of bad weather, and their upper surfaces nearly join, as though in a sleeping state. In this country the leares do not appear till June, and the flowers not till the end of July. It does not produce any blossom until it has acquired a considerable height and size.

There is a variety with fewer spines, smaller leaves, and oval pods, which is, not very accurately, named the Gleditsia inermis, the unarmed Gleditsia. The name was more accurately given by Linnæus to one of the Acacias of the genus Mimosa, now called Mimosa Houstoni, which has no thorns. The Acacias mentioned by travellers are generally those of the Mimosa genus.

Sir Archibald Edmondstone speaks of the Acacia as reminding him of English scenery; the kind mentioned seems to be that called the Egyptian Acacia:

" Having explained to the inhabitants that our object was old buildings, they informed us there were some in the neighbourhood. Accordingly, in the evening, we rode to see them; and, in our way, passed through a beautiful wood of acacias, the foliage of which, at a little distance, brought English scenery to my recollection. The trees far exceeded in size any I had ever seen of the kind; and upon measuring the trunk of one, it proved to be seventeen feet three inches in circumference*".

Thevenot, speaking of the plain called the Desert of Sin (the place where the Israelites regretted the onions of Egypt, and murmured against God, and where the manna was sent them), says, "In this plain we saw several Acacia trees, from which is obtained the gum, also called Akakia by the Arabs. It is necessary to ob-

* Journey to two of the Oases of Upper Egypt, page 44. 
serve, that the Acacia-trees now so common in France were brought to us from America, and do not afford this gum; and that which is called Acacia in the shops is the inspissated juice of the Prumus spinosa, and comes to us from Germany. These trees are neither higher nor larger than our common willows, but they have very thin leaves, and thorns. The Arabs gather the gum in the autumn, without wounding the trees, for it flows spontaneously*."

This account of their size is rather at variance with the mention made of these trees by most travellers; for they are generally described as of a gigantic height and prodigious bulk. The kind mentioned by Sir Archibald Edmondstone is the Egyptian Acacia, or true Mimosa, Mimosa vera, which is the species from which the gum is obtained. Maximilian, and some other writers, speak of the Acacia or Mimosa in general, without noting the species. Probably the trees described by Thevenot were young, or in a soil not favourable to their growth. The Acacias he speaks of as having been brought to France from America, are, doubtless, the Gleditsia, or Locusttrees afore-mentioned.

Dr. Shaw describes the Acacia vera as the largest and most common tree in the deserts of Arabia; and supposes it to be the shittim wood, or shittah tree of the scriptures. Mr. Bruce describes it as the tree of all deserts from the northernmost parts of Arabia to the extremity of Ethiopia. He says the gum is obtained by making incisions with an axe. Some authors compare the size of this tree with that of a large mulberry tree. The acacice verce succus of the ancients is supposed to have been expressed from the unripe pods $\uparrow$.

* Thevenot's Voyage du Levant, Part I. p. 318.

+ See Dr. Harris's Natural History of the Bible, p. 345. 


\section{AGNUS CASTUS.}

\section{VITEX AGNUS-CASTUS.}

Named Vitex from the flexibility of the twigs: the word Agnus in Greek has the same signification as Castus in Latin, chaste in English. The name refers to the celebrity the seeds of this shrub enjoyed in old times, for promoting chastity; wherefore, in the festivals in honour of Ceres, the Athenian matrons strewed them on their couches. From the same notion, and from the aromatic pungency of the seeds, it has been also called monk's-pepper; and hemp tree, from the form of the leaves.-French, gattilier.Italian, agno casto, vitice.

THis shrub grows eight or ten feet high, branched all the way; the leaves grow seven together at the end of a long footstalk, something in the manner of lupine leaves; gradually diminishing from the middle one to those on the outside: they are dark green on the upper side, hoary beneath. The flowers grow in spikes, a foot or more in length, at the ends of the branches; they are white or blue, and set in whorls at regular distances. They blow late in the year; the shrub is often in full blossom in the middle of October. In warm seasons when the flowers open freely, their odour is very pleasant.

The Agnus castus is a native of Sicily, Naples, Egypt, Tunis, Aleppo, Virginia, and the islands of the Archipelago. It was cultivated in this country as early as the year $15 \%$, but does not produce seeds here. It is recorded that Juno was brought into the world under a shrub of Agnus castus, on the banks of the Imbrasus, 
in the Isle of Samos; and that particular shrub was long preserved and venerated in the temple of that goddess, in Samos*.

Chaucer represents Diana as wearing a chaplet of Agnus castus, and bearing a branch of it in her hand.

"See ye not her that crowned is," (quoth she)

"All in white?"-"Madame," (quoth I) "yes :"

"That is Diane, goddesse of chastite ;

And for because that she a maiden is,

In her hand the braunch she beareth this,

That agnus castus men call properly."

Flower and the Leaf.

* See Tournefort's Voyage du Levant, vol. ii. p. 121; and Voyage d'Anacharsis, vol. vi. p. 295. 


\section{AILANTHUS.}

TEREBINTTACE.E.

FOLIGAMIA MONCCIA.

From the Amboyna name, aylanto, which signifies the tree of hearen.-French, langit.

THE Ailanthus grows forty or fifty feet high, with a straight trunk, covered with a gray bark; the leaves are large and smooth; the blossoms are numerous, but not of a pleasant odour. This is a quick-growing tree in our climate, is handsome, and very proper for ornamental plantations. The wood is hard, heary, glossy, and susceptible of a very fine polish. From the bark, when wounded, flows a resinous juice, which hardens in a few davs.

The Ailanthus is a native of China, and was first raised in England by Mr. Miller, and Philip Carteret Webb, Esq., about the year 1751. It does not produce fruit in this country.

This tree was formerly considered as a species of Rhus, and "is memorable among us," observes Mr. Martyn, "for the dispute it occasioned between Mr. Ellis and Mr. Miller, which is recorded in the Philosophical Transactions. The latter contended that it was the Fasino-ki tree, or spurious Varnish-tree of the Japanese; but it is clear that he was mistaken, for the leares of that tree are entire, and have none of the singular glands which are found in this; nor does the Ailanthus rield any juice."

In the last remark, Mr. Martyn himself appears mistaken: since it seems, and by his own account, that the bark when wounded does yield a juice. more or less. 


\section{ALATERNUS.}

\section{RHAMNUS ALATERNUS.}

RHAMNE王。

PENTANDRIA MONOGYNIA.

French, alaterne; Italian, alaterno.

The Alaternus is an evergreen shrub, with fine glossy leaves: the honey-breathing blossoms, as Evelyn terms them, come out in May; they are numerous, but very small, and are very grateful to bees.

It is a native of the south of Europe and Barbary, and was introduced into this country in 1629. "I have had the honour," observes the amiable Evelyn, " to be the first who brought it into use and reputation in this kingdom, for the most beautiful and useful of hedges and verdure in the world (the swiftness of the growth considered), and propagated it from Cornwall even to Cumberland."

Parkinson speaks of it as a rare plant in his time. "The beauty and the verdure of the leaves," says he, " abiding so fresh all the year, doth cause it to be of the greater respect; and, therefore, findeth place in their gardens only that are curious conservers of all Nature's beauties."

The fresh young shoots will give a fine yellow colour to wool; and the fishermen in Portugal dye their nets red with a decoction of the bark.

There is a variety called the Gold and Silver Alaternus; the leaves being striped with yellow and white; but the variations of colour in the foliage of shrubs usually proceed from want of strength. 


\section{ALDER TREE.}

ALNUS.

BETULIDE

MONECIA TETRANDRIA.

Alder, aller, oller, owler; French, aune, vergne; Italian, alno, ontano.

Tue common Alder, Alnus glutinosa, may, in the marshy soil it loves, be reared to a height of forty feet : the leaves are nearly circular, and of a dark green; the nerves on the lower side have white spongy tufts at the angles of their ramifications, like the leaves of the lime-tree. The bark is of a blackish hue, and, in old trees, full of clefts :

"As Alders, in the spring, their boles extend, And heave so fiercely that the bark they rend."

DRyden's Virgil. Eclogue 10.

This tree is not only a native of our island, but of Europe, from Lapland to Gibraltar; and of Asia, from the White Sea to Mount Caucasus. With us, it flowers in March and April.

The wood is valuable from its property of remaining sound a long time under water; on this account it is used for piles driven into the ground for the support of buildings in marshy places, and is said to have been used under the Rialto at Venice: in Flanders and Holland it is raised in abundance for such purposes. It also makes excellent water-pipes; and serves for various domestic purposes, as spinning-wheels, milk-vessels, bowls, spoons, 
\&c. The roots and knots furnish a beautiful veined wood to the cabinet-maker. Alder-wood is generally red; but when it has lain in bogs, it becomes black. In the Highlands, chairs are made of it, which are very handsome.

The branches make good charcoal, and the bark is used by tanners and leather-dressers. Mr. Hall says, that the country-people of Scotland often make their own shoes; and, following the example of their forefathers, to avoid the tax upon leather, privately $\tan$ hides with the bark of birch and alder*.

The bark of Alder is also used by fishermen for their nets; and the fresh wood and the young shoots, according to the season in which they are taken, and the manner in which they are prepared, furnish dye of various colours: the young shoots dye yellow, and with a little copperas, a yellowish-gray; when cut in March, they give a cinnamon colour; if dried and powdered, a fine tawny. The fresh wood dyes a rappee-snuff colour, the catkins, green ; and the bark dried, powdered, and mixed with logwood, bismuth, \&c., yields the colour called boue de Paris. It is said that the Laplanders masticate the bark, and, with the saliva so coloured, stain their leathern garments red.

The Alder makes good hedges in boggy ground, improves the soil, and tends to keep up the banks: the shade does not injure the growth of grass; some say that it cherishes it :

"The Alder, whose fat shadow nourisheth;

Each plant set neere to him long flourisheth."

W. BROWNE。

* Hall's 'Travels in Scotland, vol. ii.p. 101. 
The boughs cut in summer, and left to decay during the winter, serve the purpose of manure.

The Hoary, or Silver-leaved Alder, Alnus incana, is of smaller growth than the common Alder; the leaves are not so round, and are quite white on the under side; the wood is white, and of a closer texture. This is a native of Switzerland, Dauphiné, Siberia, the islands beyond Kamtchatka, \&c.-In direct opposition to the common Alder, it flourishes in a dry, sandy soil. It was first brought into England in the year 1780, by Mr. John Bush.

The Alder is said to have afforded the first material for boats :

"Tunc alnos primum fluvii sensere cavatas."

Virgil. Georgic I.

"Then did the rivers first feel the hollow'd alders."

Martres's Translation.

Referring to this passage, Martyn observes, that the Alder may also have given the first idea of navigation. It grows commonly on the banks of rivers; and he supposes that one of these trees, hollowed by age, may have fallen into the water, and so given the first idea of a boat to the spectators. Evelyn remarks, that the Alder is of all others the most faithful lover of watery and boggy places, $-\cdots$ a taste to which Virgil frequently alludes:

"Fluminibus salices, crassisque paludibus alni Nascuntur."

Georgic. II.

"Willows grow about rivers, and Alders in muddy marshes."

MARTyn's Translation.

Homer also more than once mentions it as growing near the water: 
" from out the caverned rock,

In living rills, a gushing fountain broke :

Around it and above, for ever green,

The bushing alders formed a shady scene."

Odysser, bookix.

" they journey down

The caverned way descending from the town, Where from the rock, with liquid lapse, distils A limpid fount, that, spread in parting rills, Its current thence to serve the city brings:

A useful work, adorned by ancient kings, Neritus, Ithacus, Polyctor, there

In sculptured stone immortalized their care:

In marble urns received it from above, And shaded with a green surrounding grove, Where silver alders in high arches twined, Drink the cool stream, and tremble to the wind."

ODyssey, book xvii.

In the second Georgic, the Roman poet again refers to its use in boats :

"Necnon et torrentem undam levis innatat alnus Missa Pado;"

"The light alder swims also on the rough flood, when it is launched on the Po."

\section{Martyn's Translation.}

Fairfax, in his translation of Tasso, enlarging upon the original in so inviting a passage, describes

"The Alder, owner of all waterish ground."

Lucan designates it as

"The floating Alder by the current borne."

Pharsalia, book iii.

Spenser, in his "Colin Clout's come home again," speaks of the Alders on the banks of the Mulla, where it is probable he may have reposed under their shade: 
"One day, quoth he, I sate, as was my trade, Under the foot of Mole, that mountain hore, Keeping my sheep among the cooly shade Of the green Alders on the Mulla's shore."

The Heliades, fabled by the ancients to have been transformed into poplars, have been said by some writers to have been changed to Alders : others will have it to be larches. Porcacchi, in his explanatory notes to the Arcadia of Sannazaro, apparently unconscious of the contradiction, ascribes this origin both to the Alder and the poplar*. It is probable, says Dr. Hunter, that the poets chose such aquatics as best suited their purpose $†$.

* Venetian edition, 1583, pp. 24, 259.

+ See Poplar. 


\title{
ALDER BUCKTHORN.
}

\author{
RHAMNUS FRANGULA.
}

RHAMNEE.

PENTANDRIA MONOGYNIA.

Black berry-bearing Alder. Black dogwood.-French, burgene.Italian, alno nero.

Thrs is one of the unarmed species of the Rhamnus; it is a black-looking shrub, growing in the woods: the leaves are about two inches long, and one broad in the middle; the flowers make but little show, being very small, and of an herbaceous colour; and these are succeeded by black berries.

In its wild state this shrub seldom exceeds four feet in height, but by cultivation may be reared to ten or twelve feet. It is a native of the greater part of Europe, and of Siberia. From the bark and the berries are prepared dyes of various colours, blue, green, yellow, and black. The blossoms are particularly grateful to bees, and the leaves are voraciously devoured by goats.

The wood is very light, and the charcoal formed from it is much prized by the manufacturers of gunpowder, who buy up all they can procure of it, and use it only for the very best gunpowder.

The juice expressed from the berries being boiled down with some gum arabic and a little alum, and then poured into bladders to grow hard, is the colour called sap green. 


\section{ALEXANDRIAN LAUREL.}

\section{RUSCUS RACEMOSUS.}

According to Miller, this genus is named Ruscus, from Rusticus, because the countrymen in old times, "used to lay the leaves on their bacon and hams to defend them from mice" It is called Alexandrian Laurel, continues he, (for rather a curious reason) because it is fit for making Laurel garlands; and from one of the species growing in Alexandria.

THIs is an elegant shrub, as Rousseau justly terms it, a beautiful evergreen; and is, at full growth, about four feet high : the leaves are of a lucid green, ending in acute points, and placed alternately upon the branches, without any foot-stalk. The flowers, of a greenish yellow, grow in bunches at the ends of the branches, and are succeeded by small red berries.

It is a native of Portugal, and of the islands of the Archipelago; and was cultivated in the Chelsea Botanic Garden, in the year 1739 .

It has been supposed to be the plant with which the ancients crowned their victors; the same notion prevailed of some other species of this genus, before this was so well known,- equally without foundation in both cases. It is now well ascertained that the bay of the ancients was the sweet bay, Laurus nobilis. 


\section{ARBUTUS.}

ERICINEA.

DECANDRIA MONOGYNIA.

The common English name is the Strawberry-tree, the fruit being very like the strawberry. Pliny gave the name of Unedo to the fruit of the common Arbutus, because it was so bitter that only one could be eaten at a time.-French, le fraisier en arbre, arbousier; the fruit, arbouse, arboise, or arboust: Italian, albatro, albaro, arbuto, rovo, corbezzolo; the fruit, corbezzola.

The Common Arbutus, Arbutus Unedo, grows to the height of twenty or thirty feet, and bears branches very near to the earth; the leaves, which are very similar to those of the bay-tree, remain on all the year, the old ones being driven off in the spring by the shooting of new. The fruit, which is called Unedo, takes a whole year in coming to perfection; so that in October and November, when the tree is adorned with a profusion of rosy blossoms, it is also loaded with ripe fruit from the blossoms of the former year.

The variety with red flowers makes a pretty appearance, when intermingled with others; the outside of these flowers being on their first appearance of a bright red, which, before they fall, turns to purple. The doubleflowered variety is not so handsome as the single, for it has only a double row of petals, and bears but little fruit.

The Common Arbutus is a native of the South of Europe, Greece, Palestine, and many parts of Asia; and of the west of Ireland, where, as well as in Spain and Italy, the country people eat the fruit. At Padua it is sold in the markets; and in the earlier ages was a common 
article of food. Virgil recommends the young twigs as a food for goats, and celebrates their use in basket-work.

The Laurel-leaved Arbutus, Arbutus laurifolia, is a native of North America: it is rery like the Common Arbutus; one of the chief distinctions is in the flowers of this turning all the same way.

The Oriental Arbutus, Arbutus Andrachne, sometimes called simply the Andrachne, is also very similar to the common species: the bark is smoother, and the leares are larger. It grows naturally in the East, particularly about Magnesia, where it is so plentiful as to be the principal fuel of the inhabitants : it grows to a middle size, with irregular branches; the blossoms are like those of the Common Arbutus, only not so numerous; the fruit, also, is of the same colour and consistence.

Wheeler obserred this tree near Athens, and saw the fruit sold at the market in Smyrna.

Evelyn complains of the neglect shown to the Arbutus in his time:- to the Arbutus, "which grows such a goodly tree, patient of our clime, unless the weather be very severe: it may be contrived into beautiful palisades, and is ever verdant. I am told this tree grows to a large size on Mount Atlas, and other countries."

Sibthorpe, trarelling in the Isle of Athos, says, in his way to the monastery of St. Paul, he passed " through a beautiful shrubbery of Kermes oaks, mixed with Arbutus and Andrachne: those trees, now laden with ripe fruit, made a beautiful appearance, and, with the smooth polished bark and shining laurel leares of the Andrachne, were highly ornamental *."

* See Travels in the East, edited by R. Walpole, M. A., being a continuation of Memoirs relating to European and Asiatic Turkey; Sibthorpe's Journal, page 64 . 
Franklin, in his Journey to the Shores of the Polar Sea, speaks of the Arbutus alpina, of which, he says, the fruit was ripe and plenty; the natives gave it the name of magpie-berry; and the traveller and his companions made a supper of it*.

Barthelemy speaks of the height of these trees in ascending Mount Ida:- " Nous étions frappés de la grosseur des cyprès, de la hauteur des Arbousiers et des Andrachnés $\uparrow$."

"We were struck with the size of the cypress, and the height of the Arbutus and Andrachne trees."

Mrs. Barbauld speaks of this tree as an inhabitant of Corsica :

"Thy swelling mountains, brown with solemn shade

Of rarious trees, that wave their giant arms

O'er the rough sons of freedom; lofty pines, And hardy fir, and ilex ever green,

And spreading chestnut, with each humbler plant And shrub of fragrant leaf, that clothes their sides With living verdure; whence the clustering bee Extracts her golden dews: the shining box, And sweet-leaved myrtle, aromatic thyme, The prickly juniper, and the green leaf Which feeds the spinning-worm; while glowing bright

Beneath the various foliage, wildly spreads The arbutus, and rears his scarlet fruit Luxuriant, mantling o'er the craggy steeps : And thy own native laurel crowns the scene."

Mrs. Barbauld's Corsica. Written in 1769 .

According to Barthelemy, very extraordinary powers

- Pages 380-394.

+ Travels of Anacharsis the Younger, vol. vi. p. 298. 
have been attributed to the fruit of the trees on Mount Helicon, of which the Andrachne is one:

"Nous étions alors sur l'Hélicon, sur cette montagne si renommée pour la pureté de l'air, l'abondance des eaux, la fertilité des vallées, la fraîcheur des ombrages, et la beauté des arbres antiques dont elle est couverte. Les paysans des environs nous assuraient que les plantes y sont tellement salutaires, qu'après s'en être nourris, les serpents n'ont plus de venin. Ils trouvaient une douceur exquise dans le fruit de leurs arbres, et surtout dans celui de l'Andrachné."

"We were then on Helicon, on that mountain so renowned for the purity of the air, the abundance of the waters, the freshness of the shades, and the beauty of the old trees with which it is covered. The neighbouring peasants assured us, that the plants there are so healthful, that serpents ceased to be venomous after feeding on them. They consider the fruit of their trees exquisitely sweet, particularly that of the Andrachne."

If it may be allowed to explain this figuratively, it may not be so extravagant a notion as at first it appears: we can believe that the productions of the Muses who preside over Mount Helicon should tend to destroy the venom of human passions, for-

"Music hath charms to soothe the savage breast :"

and surely less cannot be said for poetry, of the beauty of which music is but a part.

Sannazaro describes the Arbutus as employed in the celebration of the festival in honour of Pales, the goddess of the Roman shepherds and pastures:

_ "Si tosto come il sole apparve in oriente, e i vaghi 
uccelli sopra li verdi rami cantarono, dando segno della vicina luce, ciascuna parimente levatosi, cominciò adornar la sua mandra di rami verdissimi di Quercie, e di Corbezzoli, ponendo i su la porta una lunga corona di frondi, e di fiori di ginestre, e d'altri."

- ${ }^{66}$ As soon as the sun appeared in the east, and the charming birds began to sing on the green boughs, giving sign of approaching day, the shepherds also arose, and began to adorn their flocks with green branches of the oak, and of the Arbutus ; putting over the door a long wreath of leaves, of broom-blossoms, and other fiowers."

The Arbutus was found by Dallaway near Miletus : he speaks of that part of the country as abounding with it ; and adds, that the fruit resembles a scarlet strawberry both in size and flavour*. He describes it, too, as growing with myrtles and roses at Belgrade, a place described by Lady M. W. Montagu as a perfect paradise. "The village of Belgrade," says Mr. Dallaway, "6 is embosomed on all sides in a thick grove, and is now so much less than the paradise described by Lady M. W. Montagu, that it is only one of the finest forests in the world. The site of her former residence is now shown in a desolated field $\uparrow . "$

Toumefort tells us that brandy is distilled from the fruit of the Arbutus trees, with which the mountains of Andros in many parts are covered + .

* Dallaway's Constantinople, p. 246. † Ibid. p. 146.

+. Tournefort's Travels, vol. ii. p. 36. 


\section{ASH TREE.}

\section{FRAXINUS.}

OLEINE.

FOLYGAMIA DIOECIA.

The English name Ash, from the Saxon Esc, is said to have been given to this tree from the colour of its bark.-French, Frêne; formerly Frai, Fraysse.Italian, Frassino; on the Brescia, Uza.

The common Ash, Fraxinus excelsior, takes its specific name from the loftiness of its trunk: the leaves are pinnate, usually composed of five pair of leaflets; the blossoms grow at the sides of the branches, in loose spikes; they commonly open in March or April, but in cold seasons are sometimes as late as May. Toward the end of April, or the beginning of May, the leaves come out, and fall early in the autumn.

The fruit of the Ash is like the tongues of some birds, therefore they have been called Lingua avis and Lingua passerina by the old apothecaries, who used them in medicine, and Ornithoglossum by others. Our country people usually call them Ash keyes, but others name them Kite keyes. The botanists, from their similarity to the Samera of Columella, or the fruit of the elm, designate them by the name of Samara, and sometimes by that of Pterides, from their winged edges.

A well grown Ash is an elegant object; the bark is smooth and pale coloured; the foliage of a fine dark green, light and graceful. When the branches are pendulous, as is frequently the case, more especially with trees growing by the water-side, it is termed the Weeping Ash. 
The Ash is frequently found in old walls and rocks, in the crevices of which it insinuates its roots, and covers the surface with verdure. It is supposed that the seeds are carried into these crevices by the winds.

"The Ash asks not a depth of fruitful mould, But, like frugality, on little means It thrives, and high o'er creviced ruins spreads Its ample shade, or in the naked rock, That nods in air, with graceful limbs depends."

Bidlake's Year.

"Here amid the brook,

Gray as the stone to which it clung, half root, Half trunk, the young Ash rises from the rock, And there its parent lifts a lofty head, And spreads its graceful boughs ; the passing wind With twinkling motion lifts the silent leaves, And shakes its rattling tufts."

SOUTHEy's ROderick.

The oak itself scarcely serves a greater variety of purposes than does this tree; its wood is hard and tough, and in great request with the coachmaker and wheelwright; it is cut into palisades, hop-poles, and toolhandles:-_" in sum," says Evelyn, " the husbandman cannot be without it for his carts, ladders, and other tackling, from the pike to the plow, spear and bow."

\section{"Tough-bending Ash}

Gives to the humble swain his useful plough, And for the pecr his prouder chariot builds."

Dodsley.

Evelyn commends the Ash for fuel :- " it is," says he, "of all other the sweetest of our forest fuelling, and the fittest for ladies' chambers." Ash pollards are reckoned very serviceable where fuel is scarce, because the 
loppings burn well whether green or dry, and make excellent fires. The ashes of the wood make good potash, and the bark is used for tanning nets and calfskin.

In the north of Lancashire, when grass is upon the decline, Ash-trees are lopped as fodder for the cattle. The leaves have been used to mix with tea; and Miller tells us that in some places the poor people have made great advantage by collecting them. Whether by saving expense to themselves in lessening their consumption of foreign tea, or whether they were employed to collect these leaves for others, is not clear. Common as the use of foreign tea now is, even among the poorest of our peasantry, who, notwithstanding the little nourishment it affords them, obtain it at a great expense, it is said that many persons in China give the preference to our English herbs for the same purpose;-such is the disposition of mankind to prefer those things least easy of attainment.

Medicines have been prepared from the leaves, the bark, the seeds, and the saw-dust :- " but whether the cure be performed by the power of magic or nature," says Evelyn, "I determine not." This author tells us that " the seeds pickled tender make a delicate salading."

The Ash has, with some persons, a bad character, as a spoiler of butter. It has been observed, that in those parts of Surrey where the ash grows abundantly, the butter is rank; and this fault is supposed to proceed from the cows eating the young shoots of the tree. "So that in good dairy counties," says Miller, "they will not let an Ash-tree grow." Martyn remarks upon this, that the Romans recommended the Ash for fodder;-and, continues he, "I have passed much time in a country where Ash was almost the only tree in the hedge-rows, and never observed this rankness in the butter. Cream 
is apt to turn bitter at the fall of the leaf, and the reason is supposed to be, that the cattle then pick up decayed leaves, particularly those of the Ash; but it is the same in large low pastures where there are no trees, as in upland enclosures which abound in them."

In some respects the Ash is certainly a mischievous neighbour: the numerous shoots from the root spread so widely abroad near the surface of the earth, that they will not permit any thing else to grow near it; it also impoverishes the land, and the drip of its branches is injurious to grass and corn. It will however grow in the most barren soil, and the most exposed situations, and will bear the beating of the bleak sea-winds, so that it is a good tree to plant near the coast, where few trees flourish.

In the early ages, when the island was overrun with wood, our ancestors very naturally valued trees rather for their fruit than for their timber, and when an oak or a beech sold for ten shillings, the Ash, because it furnished no food, was valued but at fourpence.

"The Edda of Woden, however, holds the Ash in high veneration, and describes man as being formed from it. Hesiod, in like manner, deduces his brazen race of men from the Ash"."

Evelyn mentions, as some remains of the superstitious veneration paid to this tree, that the country people, in some parts of England, split young Ashes, and pass diseased children through the chasm, as a means of curing them. They have another custom equally strange;that of boring a hole in an Ash-tree, and imprisoning in it a shrewmouse: a few strokes given with a branch of 
the tree is then considered a sovereign remedy for cramps and lameness in cattle, which are ignorantly imagined to be caused by that harmless little creature.

Lightfoot says that, in the Highlands of Scotland, at the birth of an infant, the nurse takes a green stick of Ash, one end of which she puts into the fire, and, while it is burning, receives in a spoon the sap that oozes from the other, which she administers to the child as its first food.

Ash-wood is sometimes curiously veined, and is then highly valued by the cabinet-makers, who give it the name of green ebony. "The woodman who lights upon it," says Evelyn, "may make what money he will of it." Many persons have told strange stories of the curious figures to be found in Ash-wood. It has been said, that in the house of a gentleman in Oxfordshire, a diningtable, made of an old Ash, represented many figures of men, beasts, and fish; and that in Holland, an Ash, being cleft, discovered, in the several slivers, the forms of a chalice, a priest's albe, his stole, and several other pontifical vestments.

Fancy may play endless vagaries in this way, as it does in a burning fire, or in the ever-changing clouds; twenty different observers may form twenty different ideas of the same object in such speculations; although it may require the aid of a little courtly acquiescence, for one person, at the same minute, to see in the same object a camel, a weasel, and a whale.

Ash-trees do not usually grow very large; but there have been many instances of enormous growth among them. Miller mentions several: we will notice a few of the more remarkable.

"Near Kennety church, in the King's County, is an 
Ash, the trunk of which is twenty-one feet ten inches round, and serenteen feet high before the branches break out, which are of enormous bulk. When a funeral of the lower class passes by, they lay the body down a few minutes, say a praver, and then throw a stone to increase the heap which has been accumulating round the roots.

"At Doniray, near Clare Castle, in the county of Galway, is another that, at four feet from the ground, measures forty-four feet in girth; and at six feet high, thirtythree feet. The trunk has been long quite hollow, a little school having been kept in it: there are very few branches remaining, but those few are fresh and vigorous.

"Lastly, in the church-yard of Lochaber, in Scotland, Dr. Walker measured a dead Ash, the trunk of which, at five feet from the ground, was fifty-eight feet in circumference."

"Consider the value, sir, of such a piece of timber."

There is an old superstition relative to the Ash-tree, that a serpent will rather creep into the fire than over a twig of it. "This is an old imposture of Pliny's," says Evelyn, "who either took it up upon trust, or we mistake the tree."

Cowley, enumerating rarious prodigies, says-

"On the wild Ash's tops, the bats and owls, With all night, ominous, and baleful fowls, Sate brooding, while the screeches of these droves Profaned and riolated all the groves.

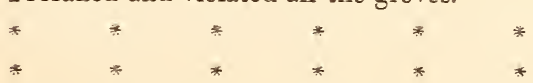

But that which gave more wonder than the rest, Within an Ash a serpent built her nest, And laid her eggrs; when once to come beneath The very shadow of an $A$ sh was death; 
Rather, if chance should force, she through the fire From its fallen leaves, so baneful, would retire."

Cowley on Plants, Book vi.

This passage is given rather for the allusion than for any beauty that is to be found in the poetry. Cowley, too, or his translator, gives a fling at Pliny: 66 For the truth hereof, take Pliny's word."

Sannazaro mentions the same notion:

"' Dell' ombra di quest' albero sempre fuggono i serpi, in modo che se dentro a un cerchio serrato da foglie di frassino, sia posto il fuoco, ed un serpe; il serpe per non dar nel frassino piu tosto si getta nel fuoco*."

"Serpents always avoid the shade of the Ash; so that if a fire and a serpent be placed within a circle of Ashleaves, the serpent, to avoid the Ash, will even run into the midst of the fire."

By the heroes of old, the Ash was used for spears, and is still in use for pike staves. Pliny says it is preferable for that purpose to either the cornel or the myrtle. Sannazaro says, also, that it is better than the hazel, lighter than the cornel, and more supple than the Service-tree.

It is recorded that the lance with which Hector was killed by Achilles, was of this wood. Sannazaro remarks that the Ash is ennobled by this circumstance:

" Molto è nobilitato per la lancia d'Achille."

Rapin also alludes to it:

"But on fair levels and a gentle soil

The noble Ash rewards the planter's toil;

Noble, since great Achilles from her side

Took the dire spear by which brave Hector died."

Rapin on Trees. 
Ovid speaks of it as useful for spears :

"Fraxirus utilis hastis."

The Ash is poetically termed warlike, from this circumstance :

"The warlike Ash, that reeks with human blood."

Garcilasso speaks of this tree in high terms :

"All know that in the woods the Ash reigns queen, In graceful beauty soaring to the sky."

Spenser designates it as "The Ash for nothing ill."

Sir Walter Scott, to express the great strength of Bertram, says,

"Like reeds he snapp'd the tough 1 sh wood."

The American Ashes, Fraxinus Americana, and pubescens, serve to increase the varieties in large plantations, but they are considered as inferior in every respect to the common Ash.

There are two other species which, on botanical grounds, have been made into a new genus, by the favourers of the natural system; and even the later writers on the Linnean artificial system have agreed in this separation, although it has also obliged them to place this new genus, Ornus, in the order diandria monogynia, at the other extremity of their system.

The Manna Ash, Fraxinus or Ornus rotundifolic, was first cultivated in this country by the Duchess of Beaufort, in 169\%. It is of humble growth, seldom exceeding fifteen or sixteen feet in height: the flowers are purple, and appear in the spring before the leaves. 
The lower part of the mountains of Calabria abound with the Manna Ash, which grows spontaneously: the woodman cuts down all the strong stems that grow above the thickness of a man's leg, which is the only care they bestow upon it. Towards the end of July, the gatherers of the manna make an horizontal gash, inclining upwards, in the bole of the tree. As it never flows the first day, another cut is made on the second, and the gatherer fixes the stalk of a maple-leaf in the upper wound, and the end of the leaf in the lower one, so as to form a sort of cup to receive the gum distilling from these gashes. The season for gathering the manna continues about a month. It is more valued when gathered in tubular pieces; to effect which they apply a straw, or a small bit of a shrub to the incision, upon which the manna runs as it oozes out; thus forming regular tubes.

The Flowering Ash, Fraxinus Ornus, or Ornus Europca, was raised at Enfield, by Dr. Uvedale, early in the eighteenth century, from seeds which were brought from Italy by Dr. William Sherrard. This is generally planted for ornament; being, in the flowering season, well covered with blossoms, which are conspicuous at a considerable distance. This tree also exudes manna, but in less quantity than the former.

The manna thus exuded from the Ash must not be confounded with the manna which makes so great a figure in the old Hebrew poetry, although it is in some respects similar. The Arabian manna, as we have been lately informed by that adventurous and intelligent traveller, Burckhardt, is exuded in June from a species of tamarix which grows in the deserts. This species of manna is very scarce, and not to be met with but in 
rainy years; it can also be collected only at early dawn, as the heat of the day melts it, and it runs into the sand. It is quite solid if kept in a cool place, but melts even by the heat of the hand: its taste is sweet and aromatic*.

* Literary Gazette。 


\section{ASPEN.}

POPULUS TREMULA.

AMENTACEE.

DIÆCIA OCTANDRIA.

This tree, called the Trembling Poplar, from the continual quivering of the leaves, is more commonly known by the name of Asp, or Aspen; derived from the German, Espe; which, in its original, signifies a Poplar of any kind.-Frrench, la Tremble.-Italian, la Tremola, Alberella, Alberetto.

THE Aspen is a native of many parts of Europe, in moist woods and marshes: in the little islands of the Lake of Cachemire, too, it is said to grow abundantly. It has a smooth green bark; the leaves are nearly heartshaped, and being very white on the under side, have a good effect when blown about by the wind, and contrasted with trees of darker foliage.

The trembling of the Aspen leaf is proverbial: by some, it is supposed to proceed from the leaf-stalks being flattened at the end; but that is common to other poplars, whose leaves are not so restless. Dr. Stokes ascribes it to the plane of the long leaf-stalk being at right angles with that of the leaf; thus allowing a freer motion than they could have had if the planes had been parallel. Dr. Aikin attributes it to the length and slenderness of the leaf-stalks; but the Highlanders set the question at rest at once; they believe that the cross of Christ was made of this tree, and that therefore the tree can never rest. They can scarcely be conscience-stricken, for the cross could not have been made of the leaves; perhaps 
they struggle to escape from the wicked wood on which they grow.

The tree is of speedy growth, but impoverishes the land, and destroys the grass in its immediate neighbourhood. The wood is light, smooth, soft, and durable in the air. It is used for hoops, milk-pails, clogs, packsaddles, \&c., and for fire-wood. Spenser calls it, "the Aspen good for staves." The bark is the favourite food of beavers. In some countries the bark of the younger trees serves for torch-wood. Evelyn, comparing this tree with the Black Poplar, says, it " thrusts down a more searching foot, and in this, likewise, differs, that he takes it ill to have his head cut off."

It has been maliciously affirmed that of the leaves of the Aspen were made women's tongues, "which seldom cease wagging*."

Sir Walter Scott describes its appearance in comparing it to a countenance of varying expression :

"With every change his features played, As Aspens show the light and shade."

Again, speaking of superstition, he says,

" Hearts firm as steel, as marble hard, 'Gainst faith, and love, and pity barred, Have quaked like Aspen leaves in May, Beneath its universal sway."

Spenser compares it to a person under the influence of fear :

"His hand did quake, And tremble like a leaf of Aspen green."

* See Gerarde's Herbal. 
The lightest breeze, though it stir no other leaf of the forest, will set the Aspen tree in busy motion:

"And the wind, full of wantonness, woos like a lover The young Aspen trees, till they tremble all over."

T. MOORE.

Thomson says, in describing

- - A perfect calm; that not a breath

Is heard to quiver through the closing woods,

Or rustling turn the many-twinkling leaves

Of Aspen tall."

It may one day be discovered by some poetic woodman that the Aspen was formerly a beautiful, or an unfortunate nymph; perhaps the most timid of the sisters of Phaeton; for trees of such origin are, it is said, apt to tremble when any one approaches them.

"Long time they thus together travelled, Till, weary of their way, they came at last Where grew two goodly trees, that fair did spred Their arms abroad, with gray moss overcast; And their green leaves, trembling with every blast, Made a calm shadow far in compass round:

The fearful shepherd often there aghast

Under them never sate, ne wont there sound His merry oten pipe, but shunn'd the unlucky ground.

"But this good knight, soon as he them 'gan spy,

For the cool shade him thither hast'ly got;

For golden Phœbus now, that mounted high,

From fiery wheels of his fair chariot

Hurled his beam, so scorching cruel hot,

That living creature mote it not abide ;

And his new lady it endured not.

There they alight, in hope themselves to hide

From the fierce heat, and rest their weary limbs a tide 
"Fair seemly pleasaunce each to other makes,

With goodly purposes there as they sit;

And in his falsed fancy he her takes

To be the fairest wight that lived yet;

Which to express he bends his gentle wit,

And thinking of those branches green to frame

A garland for her dainty forehead fit,

He plucked a bough; out of whose rift there came

Small drops of gory blood, that trickled down the same.

"Therewith a piteous yelling voice was heard, Crying, ' $\mathrm{O}$ spare with guilty hands to tear My tender sides, in this rough rind embard;

But fly, ah fly far hence away, for fear

Lest to you hap that happened to me here,

And to this wretched lady, my dear love;

O too dear love, love boughi with death too dear !'

Aston'd he stood, and up his hair did hove,

And with that sudden horror could no member move.

"At last, when as the dreadful passion

Was overpast, and manhood well awake,

Yet musing at the strange occasion,

And doubting much his sense, he thus bespake:

'What voice of damned ghost from Limbo lake,

Or guileful spright, wand'ring in empty air,

Both which frail men do oftentimes mistake,

Sends to my doubtful ears these speeches rare,

And rueful plaints, me bidding guiltless blood to spare?"

"Then, groaning deep :-' Nor damned ghost,' quoth he,

' Nor guileful spright to thee these words doth speak;

But once a man, Fradubio-now a tree:

Wretched man! wretched tree! whose nature weak,

A cruel witch, her cursed will to wreak,

Hath thus transform'd, and placed in open plains,

Where Boreas doth blow full bitter bleak,

And scorching sun does dry my secret veins;

For though a tree I seem, yet cold and heat me pains.'" 
Should the reader desire to be further acquainted with the mournful adventures of these sylvan lovers, let him turn to the second canto of the first book of Spenser's "Faerie Queene." 


\section{BARBERRY BUSH.}

\section{BERBERIS.}

BERBERIDEE.

HEXANDRIA MONOGYNIA.

Barberry, Berberry, or Pipperidge-bush. Berberis is said to be the Arabic name. French, épine vinette; Italian, crespino.

The Common Barberry, Berberis vulgaris, is a shrub eight or ten feet in height; the stems are upright and branched; both stems and branches being armed with sharp thorns, which commonly grow by threes. Linnæus affirms that the first leaves of the present year change into thorns the next; but other botanists differ from him in this opinion. The flowers grow in pendulous racemes towards the end of the branches; they are yellow, with orange-coloured dots at their kase. The berry is green when first formed; when ripe, of a bright red.

This fruit is made into jellies and other preserves, and an essential salt is obtained from them: they are sometimes pickled. Their acidity is unpleasant to birds; but insects of various kinds are remarkably fond of them. The leaf has an agreeable acid taste, and is a pleasant ingredient in salads.

Though pleasant at a short distance, the flowers when near have an offensive odour; therefore, these shrubs are seldoin planted many together, or very near to walks which are much frequented. There is a heavy charge against this shrub; - that it will not suffer corn to thrive near it : it is said, the ears will not fill, and that this influence extends to a distance of three or four hundred 
yards. This is ascribed to the aptness of the Barberry to afford a lodgment for the growth of a small species of mildew fungus, which, according to Sir Joseph Banks and others, may be transferred to the corn; but this is certainly an erroneous notion, for the two plants are of very different structure, and of different genera; the one being the Rostelia berberidis, and the other the Ustilago segetum, of Gray's " Natural Arrangement of British Plants." Some who say they have made experiments are convinced of the truth of this observation; others are incredulous; and a third party, in their zeal against modern innovations, as they term them, although totally ignorant of the subject, are ready to exclaim, "Mallem cum Banksio vel Smithio errare quam cum aliis recte sentire:"- "I had rather be in the wrong along with Banks or Smith than in the right with their opponents."

The Barberry is a native of most parts of Europe, in woods, coppices, and hedges. In England, it is found chiefly in a chalky soil. The flowers appear in May, and the berries ripen in September.

The other species are mostly of lower growth than the Common Barberry : the box-leaved kind is rather tender while young. The wood of the holly-leaved Barberry, Berberis ilicifolia, is, on account of its great elasticity, used by the inhabitants of Terra del Fuego for bows.

This plant most admirably illustrates the irritability that some vegetables are possessed of, and which may almost be said to come near to voluntary motion of animals; for if the base of the thread which supports the anther be irritated by a straw, by an electric shock, or by the focus of a burning glass, the anther will be raised up by a sudden jerk, so as to touch the end of the style in the centre of the flower; this effect appears to take place 
naturally by the irritation produced by flies and other insects coming to get the honey which is secreted by two oblong glands, placed at the base of each of the threads, or filaments of the stamen. Nearly the same fact is exhibited by the common stinging-nettle; and this last is still more easily procured for trial. 


\section{BEECH TREE.}

\section{FAGUS SYLVATICUS.}

Fagus is from the Greek, and signifies to eat; the nuts of the Beech having been a common article of food in the early ages. French, betre, hetre; Italian, faggio.

THE Beech sometimes grows to an enormous size; and in its usual growth, is a fine, lofty and spreading tree:

"The Beech that scales the welkin with his top."

The trunk is straight, and covered with a whitish bark ; the leaves are about three inches long, and nearly as wide ; smooth and glossy; they remain on the tree until driven off by the shooting of new ones in the spring. The fruit is composed of two nuts joined at the base, and covered with an almost globular involucre, which has soft spines on the outside; but within, is delicately smooth and silky :

\section{"The Beech, of oily nuts \\ Prolific."}

The Beech is a Briton, and a native of most of the countries of Europe; but not in very high or cold situations. It does not thrive well in light lands, and of all exposures, least likes the west: it grows well in a rocky, chalky soil. In some parts of Hertfordshire, where the soil is a strong clay full of flints, it grows very large and beautiful. In the course of the last century, large plantations of Beech have been made both in England and Scotland. 
Mr. White speaks of the Beech as one of the most grand and lovely of all the forest-irees :- " Whether we consider its stately trunk," said he, "its smooth, silvery rind, its glossy foliage, or its graceful, spreading, and pendulous boughs."

It is considered as a handsome tree to stand alone, on account of the regular growth of its branches. Gilpin says it is not picturesque; and in landscape, perhaps, it is less so than many. To appreciate the beauty of the Beech, we should walk in a wood of them; they continue green as long as any of the deciduous trees, and a young Beech has a sunny green that seems almost to contain its own light; it looks as if it were independent of sunshine, and would preserve its colour in the deepest darkness of midnight. In winter, the leaves become brown or orangecoloured; and it has been observed, that some of the finest oppositions of tint have been produced by the union of this tree with the oak at that season. Its smooth, gray bark, too, is usually scattered with mosses and lichens of various hues, which form beautiful contrasts.

Beech-wood is used for purposes innumerable; among others, for the sounding-boards of musical instruments : "The soft Beech

And close-grained Box employ the turner's wheel; And with a thousand implements supply Mechanic skill."

Dodsley.

In some places, the leaves are used instead of straw, for mattresses. The nuts, or mast, are greedily devoured by mice, birds, and squirrels ; they are said, when fresh, to occasion giddiness and headach; but when dried and powdered, to make wholesome bread. Roasted, they have been substituted for coffee. In Siberia, the poor use 
the expressed oil instead of butter. In northern countries, however, they do not yield much oil; Linnæus informs us, scarcely any, in Sweden.

It is certain that Henry Fielding, the author of those exact pictures of English society in the beginning of the last century, "Tom Jones" and "Joseph Andrews," once speculated largely on the manufacture of beech oil: and the expression of it by a joint stock company was also one of the bubbles, as they are emphatically and justly called, of the South Sea year, or 1721. It is said that a project was once formed for paying off the national debt with the oil of beech nuts.

The wood, the leaves, the bark, the ashes,-every part of this tree is useful. Cowley rather quaintly enumerates some of its uses in housewifery:

"Hence in the world's best years, the humble shed Was happily and fully furnished;

Beech made their chests, their beds, and their join'd-stools;

Beech made the board, the platters, and the bowls."

Beechen bowls are often mentioned in ancient pastorals, and appear to have been much prized by the shepherds: but that was in the golden age:

\footnotetext{
"Nec bella fuerunt,

Faginus adstabat cum scyphus ante dapes."

Tibullus.

"No wars did men molest,

When only beechen bowls were in request."
}

In Virgil's third Eclogue, the two shepherds, Menalcas and Damætas, boast of their beechen bowls wrought by the hand of Alcimedon.

Milton, speaking of poets, says that the writers of elegy may be allowed wine and good cheer, but that 
such as treat of heroes and of gods must live more frugally :

"Let herbs to them a bloodless banquet give, In beechen goblets let their bev'rage shine, Cool from the crystal spring their sober wine."

Milton.

The Beech has been particularly celebrated for its shade:

"Tityre, tu patulæ recubans sub tegmine fagi Sylvestrem tenui Musam meditaris avena."

Eclogue i.

"Beneath the shade which beechen boughs diffuse, You, Tityrus, entertain your sylvan muse."

It seems to have had the honour of shading the sylvan god himself. In the Faithful Shepherdess, the satyr who brings fruit to Clorin says-

"Till when humbly leave I take,

Lest the great Pan do awake, That sleeping lies in a deep glade, Under a broad Beech's shade."

\section{Beaumont and Fletcher.}

"There, at the foot of yonder nodding Beech That rears its old fantastic roots so high, His listless length at noontide would he stretch,

And pore upon the brook that bubbles by."

Gray.

Garcilasso has some delightful lines upon this subject:

"The sun, from rosy billows risen, had rayed With gold the mountain tops, when at the foot Of a tall Beech romantic, whose green shade Fell on a brook, that, sweet=voiced as a lute, Through lively pastures wound its sparkling way, Sad on the daisied turf Salicio lay; And with a voice in concord to the sound 
Of all the many winds and waters round, As o'er the mossy stones they swiftly stole, Poured forth in melancholy song his soul

Of sorrow; with a fall

So sweet, and aye so wildly musical,

None could have thought that she, whose seeming guile Had caused his anguish, absent was the while, But that in very deed the unhappy youth Did, face to face, upbraid her questioned truth."

WIFFen's Garcilasso.

"Under the branches of this Beech we flung

Our limbs at ease, and our bent bows unstrung. Thus idly lying, we inspired with zest

The sweet fresh spirit breathing from the west. The fowers with which the mosses were inlaid A rich diversity of hues displayed, And yielded scents as various; in the sun, Lucid as glass, this clear shrill fountain shone, Revealing in its depth the sands like gold, And smooth white pebbles whence its waters rolled."

"I ran to meet you, as the traveller

The same.

Gets from the sun under a shady Beech."

Hunt, from Theocritus.

The Beech has been celebrated more, perhaps, than any other tree, as the lover's tablet. Shepherds, in old times, carved the stories of their loves, their songs, their mistresses' names, and their tender lamentations, on the bark of the living tree, or on strips of bark, which served them for paper :

"Immo hæc in viridi nuper quæ cortice fagi

Carmina descripsi, et modulans alterna notavi, Experiar." VIRGIL, Eclogue v.

" Or shall I rather the sad verse repeat, Which on the Beech's bark I lately writ; I writ, and sang betwixt?" Dryden's Translation. 
They had a superstitious notion that with the words, which increased in size with the growth of the tree, their hopes would grow in proportion:

_— " tenerisque meos incidere amores Arboribus ; crescent illæ, crescetis amores."

Virgil, Eclogie x.

"The rind of every plant her name shall know, And as the rind extends the love shall grow."

"At length, a tender calm

Hushed by degrees the tumult of her soul;

And on the spreading Beech, that o'er the stream

Incumbent hung, she with the sylvan pen

Of rural lovers this confession carved,

Which soon her Damon kissed with weeping joy."

THONSON.

“Mentre Ergasto canto la pietosa canzone, Fronimo, sopra tutti i pastori ingegnosissimo, la scrisse in una verde corteccia di Faggio, e quella di molte ghirlande investita appico ad un albero, che sopra la bianca sepoltura stendevasi rami suoi."-Arcadia di Saxwazaro, Prosa 6.

"While Ergasto sung this mournful song, Fronimo, the most ingenious of all the shepherds, wrote it upon a piece of green Beech-bark, and adorning it with garlands, hung it upon a tree that stretched its boughs over the white sepulchre."

"Not a Beech but bears some cipher,

Tender word, or amorous text;

If one vale sounds Angelina,

Angelina sounds the next."

Don Luis de Gongora.

The meanest of our peasantry would be ill pleased in the present age to feed on Beech-nuts; but formerly they 
were the food of man, as also were acorns. Hence it has been aptly termed"The foodful Beech."

Evelyn mentions a Roman consul, Passienus Crispus, "6 who fell in love with a prodigious Beech, of a wonderful age and stature, which he used to sleep under, and would sometimes refresh it by pouring wine at the roots."

Wordsworth gives an agreeable picture of a Beechtree :

"A single Beech-tree grew

Within this grove of firs, and in the fork

Of that one Beech appeared a thrush's nest;

A last year's nest, conspicuously built

At such small elevation from the ground, As gave sure sign that they who in that house Of nature and of love had made their home, Amid the fir-trees all the summer long Dwelt in a tranquil spot."

The abundance of coal in this country renders us indifferent to the characters of wood as fuel; but on the continent; beech wood is preferred before all others for chamber fires, as it kindles easily, and gives a clear lively fire. The bois d'Andelle burnt in the genteelest houses in Paris is almost entirely beech. 


\title{
BIRCH TREE.
}

\author{
BETULA.
}

BETULIDEE.

MONECIA TETRANDRIA。

French, bouleau ; Italian, maio, maiella, betula, or betulla. The latter name is common also to the Spanish and Portuguese.

The Birch, Betula alba, is a native of Asia, chiefly in mountainous situations; and of Europe, from Lapland to the subalpine parts of Italy, so that it is no stranger to this country. This tree may be immediately distinguished by its bark, which is of a silver colour, or sometimes approaching to a flesh colour; by the airy appearance of its small leaves, in summer, and in winter by the elegant drooping of its bare boughs. There are few tiees so ornamental in a leafless state as the Birch-tree, which some have compared to an elegant woman, from the peculiar grace of its appearance. Mr. Coleridge terms it the

\section{" most beautiful}

Of forest teees, the Lady of the woods."

Keats speaks of

\section{Of delicate Birch-trees."}

- It is happily described by Wilson, in his Isle of Palms, \&c. :

" on the green slope

Of a romantic glade we sat us down, Amid the fragrance of the yellow broom, While o'er our heads the weeping Birch-tree streamed Its branches, arching like a fountain shower." 
Evelyn denominates the Birch wood the very worst of timber; yet it is useful for many purposes. "It claims a memory too," says he, "for arrows, bolt-shafts (our old English artillery); also for bowls, dishes, ladles, and other domestic utensils, in the good old days of more simplicity, yet of better and truer hospitality."

Spenser calls it " the Birch for shafts."

The natives of New England make canoes and many other articles of Birch wood, which they join very curiously with a sort of thread made of cedar roots. Martyn says, "they make pinnaces of Birch, ribbing them with white cedar, and, covering them with Birch bark, sew them with thread of spruce roots, and pitch them; as it seems we did even here in Britain."

In Lancashire a great number of besoms are made of Birch twigs, for exportation. The bark will dye yellow, and is used to fix fugacious colours. The Highlanders of Scotland use it for tanning leather; and the outer rind they burn instead of candles. It is used for tanning in Norway also; and with it the Norwegian fisherman dyes his nets and sails of a deep red colour, which is said to render them more durable. Small fragments of the bark are braided by the Laplanders into shoes and baskets, and they use large and thick pieces, by way of surtout, to keep off rain ; making a hole in the middle to admit the neck. The Swedes frequently make the inner sole of their shoes of a piece of Birch-bark, which is said to be preferable to leather for that purpose, its oily nature so well resisting wet.

There is no part of this tree but is useful, but the bark appears to be the most valuable part of it. Before the invention of paper, the epidermis, and the inner white 
cuticle, were used as writing tablets. Mr. Coleridge describes-

"A curious picture, with a master's haste Sketched on a strip of pinky-silver skin peeled from the birchen bark!"

The Kamschatkadales make hats and drinking-cups of Birch-bark. The Russians, Poles, Norwegians, and Swedes, cover the roofs of their houses with it. Sometimes the bark is the outward covering; sometimes it is covered with turf three or four inches thick; these roofs are considered very durable, and even though the water should penetrate the turf, it is thrown off by the bark. The Swedes sometimes cover the bark with a thatch thickly scattered with grass-seeds, which produce a plentiful crop; and these roofs have a very pleasing appearance. Mr. Brooke says, that he has seen fir-trees of tolerable size growing on the roofs of these cottages.

To the northern peasant the Birch is indeed of the utmost importance-almost indispensable: he uses it not only in building, but for many articles of household furniture. It furnishes him also with fuel; and, in times of scarcity, even with food. The Swedes are often reduced to hard and scanty fare, or rather they seldom have any other, and the inner bark of the Birch, or firtree, is dried, ground, and made into bread, sometimes mixed with corn, sometimes alone. The peasants of Norway and Lapland also eat of this bark bread. Dr. Clarke, in speaking of a family of Laplanders, says, " The bread of the family was full of chaff and the bark of the Birch, and it was only when stewed in butter that we were able to swallow it, and even then with difficulty*. 
A wine is made from the sap of the Birch-tree, from which a spirit is extracted. The notable English housewife was formerly skilled in making Birch wine:

"And though she boasts no charms dirine, Yet she can carre, and make Birch wine."

T. WARTON. "eren afflictive Birch,

Cursed by unlettered idle youth, distils

A limpid current from her wounded bark, Profuse of nursing sap."

Thus it appears that the Birch-tree supplies to the northern peasant his house; his bread, his wine, and the vessels to put them in; and some part of his clothing; the seeds too are the food of the ptarmigan, upon which, in a great measure, he subsists; and the leares sometimes furnish his bed. From the Birch, also, is prepared the Moxa, which he considers an efficacious remedy in all painful diseases.

"Even its leares," says Mr. Drummond, "are not unimportant, being employed by the Finland women in forming a soft elastic couch for the cradle of infancy. Acerbi has given a specimen of a wild lullaby song in which this is alluded to, and which seems to have been copied in these lines of Leyden :

"Sweet bird of the meadow, soft be thy rest!

Thy mother will wake thee at morn from thy nest;

She has made a soft nest, little red-breast, for thee,

Of the leaves of the Birch, and the moss of the tree*."

Birch-wood is thought to make the best charcoal, and its soot is a good lamp-black for printers' ink. The leaves are good fodder for horses, kine, sheep, and goats ;

* Drummond's First Steps to Botany, p. 328. 
and the seeds are the favourite food of the Siskin, or Averdevine.

The Birch delights in a moist soil, but is not confined to the water-side. Cowley is severe upon this gentle and amiable-looking tree, for its proneness to revenge, and to punish petty crimes, to the great terror of boys at school. The same allusion is made by Shenstone, in his Schoolmistress :

"And all in sight doth rise a Birchen tree, Which Learning, near her little dome, did stowe; Whilom a twig of small regard to see, Though now so wide its waving branches flow, And work the simple vassals mickle woe;

For not a wind might curl the leaves that blew But their limbs shuddered, and their pulse beat low;

And as they looked they found their horror grow, And shaped it into rods, and tingled at the view."

He represents the dame, too, as wielding in her hand, for a sceptre, "tway Birchen sprays."

It is said that some Birch-trees are so curiously veined as to represent birds, beasts, trees, \&c. - "6 to say nothing," says Evelyn, "of the magisterial fasces, for which, anciently, the cudgels were used by the lictors for lighter faults, as now the gentler rod by our tyrannical pedagogues."

The pensive drooping of the branches of this tree harmonizes well with the plaintive tones usually considered as the residence of the nightingale:

"And to yon bower of Birch

I 'll meanwhile pass, in search

Of the sweet nightingale's secreted nest; 
And beautiful Gravina, it shall be

Thine for one rosy kiss-I know the ivied tree."

WifFen's Garcilasso.

Mr. Brooke remarks that it is curious, in travelling northward, to observe the gradual diminution in the size of the Birch-tree, "till from a tree, it assumes, in the higher latitudes, the appearance of a dwarf shrub, seldom rising higher than a few feet above it*."

The Birch, nevertheless, bears a degree of cold in which few other trees will grow : that and the fir tree are among the most hardy,-and happy is it for the peasants of Sweden, Norway, \&c., that they are so. Browne justly terms this tree "The cold-place loving Birch."

The Canada Birch, Betula lenta, will grow sixty feet high or more. A liquor flows from it, when wounded, which is drunk in Kamtschatka without fermentation: with the wood they build sledges and canoes, and convert the bark into food by stripping it off when green, cutting it into long narrow pieces, drying it, and stewing it with their caviar.

Very pretty baskets are made of the twigs; the bark serves to write upon, and may be made into books.

The Black Virginian Birch, Betula nigra, is as large of growth as the Canada species.

* Brooke's Sweden, p. 56. 


\section{BIRD CHERRY.}

\section{PRUNUS.}

Also Fowl-Cherry, Cluster-Cherry ; in Scotland Hagberry.

The Common Bird Cherry, Prunus padus, is a Briton, and also a native of the greater part of Europe, and even of the severe climate of Siberia. It will thrive either in woods, groves, or fields, hills or dales, provided the soil be not moist; and it is very frequently planted in ornamental grounds. It grows about twelve feet high, and is well clothed with leaves: the blossom is not so handsome as that of the Common or Wild Cherry, being much smaller; the scent is very strong, and, to many persons, unpleasant. The fruit changes from green to red; and, when ripe, to black. The fresh berries are considered nauseous, but being bruised and infused in wine or brandy, they give it an agreeable flavour. The infusion in brandy is frequently drunk in Scotland. Dr. Clarke says the Swedes flavour their distilled spirits with the blossoms. The birds take great delight in these berries; and the name of Bird-cherry was probably given to this fruit because seldom eaten but by birds.

The wood, being smooth and tough, is made into knife and whip handles; it is used also in cabinet-work.

The Red Bird-Cherry, or Cornish Cherry, Prunus rubra, grows twice the height of the former; the fruit is larger, and red when ripe.

The American Bird-cherry, Prunus serotina, is a $\mathrm{E} \%$ 
native of Virginia. This tree is thirty feet high; the fruit is larger than the preceding, and is black when ripe; but it has scarcely time to ripen before it is devoured by birds.

The wood is beautifully veined with black and white; and, as it takes a fine polish, is frequently used in cabinetwork. Parkinson calls this tree the Virginia CherryBay. It was cultivated here in 1629 .

The Evergreen Bird-cherry, Prumus Caroliniana, as the English name implies, retains its verdure all the year. In this country it seldom exceeds three feet in height, but sends out branches on every side: the leaves are of a fine lucid green. This species was brought from South Carolina, under the title of Bastard Mahogany; so called from the colour of its wood. It was cultivated by Miller in 1759 .

The Perfumed Bird-cherry, Prunus Mahaleb, has a fine veined wood; which, as the tree grows in great abundance about the village of St. Lucie in Lorrain, the inhabitants have been induced to use in turnery, and their manufactures supply in France the place of our Tunbridge ware. It is called St. Lucia wood, whence it has been supposed to be a West Indian wood; the name St. Lucie being confounded with that of one of the isles. The fresh wood having a fine scent, which it communicates to warm water, the foreign barbers use an infusion of it to make the lather for shaving. 


\title{
BOXTHORN.
}

\author{
LYCIUM.
}

French, Liciet; Italian, Licio.

The European Boxthorn, Lycium Europaum, is a native of the South of Europe; it grows about ten feet high; the flowers are of a dull purple; the leaves are spear-shaped, and the berries dark red. Ray found it about Montpelier, flowering both in March and autumn.

Clusius says, the Spaniards eat the young shoots with oil and vinegar.

In Tuscany, this shrub is used for hedges, and is generally known by the name of Spina di Crucifisso, being one of the many thorny shrubs supposed to have afforded the crown of thorns which was put upon the head of Christ before the crucifixion. Some pains, however, have been taken to show that the crown was used in mere derision, and not with an intention to inflict bodily pain. 'The plant now called Christ's Thorn is an unarmed species of Rhamnus.

The Tartarian Boxthorn, Lycium Tataricum, has an elegant appearance on account of the whiteness of the branches; it is armed with awl-shaped spines, surrounded at their base with leaves and flowers. The flower is white, with a purple border, and is succeeded by a black and succulent berry, about the size of a currant. 


\title{
BLADDER-NU'T 'TREE.
}

\author{
STAPHYLEA.
}

CELASTRINA.

PENTANDRIA TRIGYNIA.

Staphylea, from its bladder-like seed-vessels. In French, $\boldsymbol{B} a$ guenaudes à patemostres, from the friars using the seeds to make their beads of; by the Italians, pistacia salnisticke; and by our own country people, St. Antony's Nut, Wild Pistacia, or Bladdernuts, from the form of the case which covers the seeds.

The Common Bladder-Nut Tree, Staphylaa pinnata, is a small low tree, somewhat like an elder, which is found in hedges, especially in the North of England; but there is some doubt if it was originally a native; and it has apparently been introduced from Asia Minor, Italy, or France, in all which countries it is not uncommon.

The wood of this tree is very hard and white; but the plant is most remarkable for its fruit, which consists of two or three bladders, like the calyces of the winter cherries, only of a pale green colour, which are joined together on a stem; each containing one or two very hard seeds, about the size of a small hazel-nut, covered with a woody, as it were, varnished coat of a reddish colour, and containing a greenish kernel, which is at first sweet to the taste, but at length becomes nauseous, and often provokes sickness.

The chief use of this tree, which appears to be the Staphylodendron of Pliny, is to form hedges, for which purpose it answers very well, and makes a very pleasing 
variety, on account of its peculiar and very showy fruit, which remains on the tree for a considerable time. This fruit is now nearly useless, being no longer required for the purposes whence it obtained a name. 


\title{
BRAMBLE.
}

\author{
RUBUS.
}

POTENTILLEK.

ICOSANDRIA POLYGYNIA.

Rubus, from the redness of the twigs, or of the juice of the fruit. French, ronce; Italian, rogo.

Tнг Common Bramble, Rubus fruticosus, so well known in our hedges, by every child in the country, as the mother of the blackberry, is sometimes found very useful to defend whitethorn or other hedges from sheep, cattle, \&c. The green twigs yield a black dye; and, where mulberry-leaves are not to be had, these are often substituted as a food for silkworms. The berries, in addition to their common name of blackberry, are, in some places, called bumblekites; in others scaldberries, from their supposed quality of giving scald-heads to children who eat profusely of them.

Cowper used to feed upon them, as he tells us, when he played truant from school:

"For I have loved the rural walk through lanes Of grassy swarth, close cropp'd by nibbling, sheep, And skirted thick with intertexture firm Of thorny boughs; have loved the rural walk O'er hills, through valleys, and by rivers' brink, E'er since a truant boy I passed my bounds, To enjoy a ramble on the banks of Thames: And still remember, nor without regret, Of hours that sorrow since has much endeared, How oft, my slice of pocket-store consumed, Still hungering, pennyless and far from home, 
I fed on scarlet hips and stony haws, Or blushing crabs, or berries that emboss The Bramble, black as jet, or sloes austereHard fare! but such as boyish appetite Disdains not; nor the palate, undepraved By culinary arts, unsavoury deems."

The double-flowered variety of the Bramble makes a good figure in ornamental plantations.

To this genus belong's another very ornamental shrub, the Virginian Flowering Raspberry, Rubus odoratus: it does not ripen its fruit here, but is esteemed for the beauty of the blossoms, which it produces plentifully, and in constant succession throughout the summer, and for the large and elegantly formed leaves, which also are delightfully fragrant.

Linnæus mentions a Bramble, called the Arctic, or the Dwarf Crimson Bramble, Rubus Arcticus, of which the fruit is nearly as large as a mulberry; purple, fragrant, and very pleasant. 'He speaks of it with gratitude, as he says, for the benefit he received from it in his Lapland journey; the vinous nectar of its berries having often recruited his spirits when he was almost sinking with hunger and fatigue. He tells us these are more highly valued than any other of the Swedish wild berries, and that, in the province of Norland, the principal families make a jelly, a syrup, and a wine from them; part of which they consume themselves, and send a part to their friends in Stockholm, as a dainty of the finest and rarest kind.

Dr. Clarke says, "the flavour of its berries is finer than that of the hautboy strawberry, which perhaps it more resembles than any other kind of fruit. These berries are of a dark red colour, equal in size to those of our common raspberry trees; but the plant is so diminutive, 
that an entire tree, with all its branches, leaves, and fruit, was placed within a phial, holding about six ounces of alcohol, in which state it has been preserved even with its colour unaltered, and may be so for any length of time, provided it be kept as free from the external air as if it were hermetically sealed. The smell of the fruit, when fresh gathered, is delicious *."

Dr. Clarke speaks no less gratefully of another Swedish plant of this genus than Linnæus does of the Arctic Raspberry. He considered it, indeed, the preserver of his life; a circumstance which gives an interest to this plant, sufficient to authorise our citing his own words, though at some length :

"In the evening Mr. Grape's children came into the room, bringing with them two or three gallons of the fruit of the Cloudberry, or Rubus chamcemorus. This plant grows so abundantly near the river, that it is easy to gather bushels of the fruit. As the large berry ripens, which is as big as the top of a man's thumb, its colour, at first scarlet, becomes yellow. When eaten with sugar and cream, it is cooling and delicious, and tastes like the large American hautboy strawberries. Little did the author dream of the blessed effects he was to experience by tasting of the offering brought by these little children, who, proud of having their gifts accepted, would gladly run and gather daily a fresh supply, which was as often blended with cream and sugar by the hands of their mother; until at last he perceived that his fever rapidiy abated, his spirits and his appetite were restored, and when sinking under a disorder so obstinate that it seemed to be incurable, the blessings of health were 
restored to him, where he had reason to believe he should have found his grave. The symptoms of amendment were almost instantaneous after eating of these berries*."

In another passage he says: "A kind of jelly, made of the fruit of the Cloudberry, was served with cream for our dinner. Our benevolent host, finding the salutary change produced in the author's health by eating of this fruit, caused it to be sent to table in all the various ways of cooking it known in Sweden. The Lapps make a jelly of it, by boiling it with fish. At this time, the bogs near the water-side were covered with the fruit in a ripe state. Our Swedish interpreter gathered half a bushel of the berries in an hour and a half. In its natural state, no fruit looks more beautiful. We endeavoured to preserve a small cask of it to send to England; but wanting a sufficient quantity of sugar, the acetous fermentation took place, and the whole was spoiled. Whenever we walked near the river, we found whole acres covered with its blushing berries, hanging so thick, that we could not avoid treading upon them. As they ripen, they lose their crimson hue, and turn yellow ; the flavour of the fruit is not then so refreshing to the palate. They are always most delicious when they have been cooked. In their unripe state, they resemble in taste those diminutive stunted apples gathered from codlin-trees, which boys call crumplings. Although they flourish most in marshy places, their roots do not strike into the swamp, but are found covering the hard and dry mounds of earth which rise above it + ."

Linnæus believed the Rubus Arcticus, and the Rubus

* Clarke's 'Travels, vol. iii. p. 3 i6.

+ Ibid. p. 417 . 
chamcemorus, to grow only in Sweden, and even there not in the southern provinces. The fruit of both these species is sent in casks to Stockholm, annually; where it is used in soup, and as a sauce with meat; as well as for making vinegar, and other culinary purposes. The Cloudberry is much more plentiful than the other, and is eaten by the Lapps with the milk of the rein-deer. During the winter, they preserve it in snow.

Dr. Clarke was not ignorant that the Cloudberry grows in this country, but he took pains to bring some of the fruit from Sweden, because it grows there in greater perfection than it does here. It is a native of some of our northern counties, and is not uncommon on the mountains of Scotland and Wales. The name of Cloudberry is supposed to have reference to its growth in mountainous situations. It is also called Knot, or Knout-berry.

Dr. Clarke mentions this fruit many times in the course of the volume, and is never weary of praising it. "This singular fruit," says Mr. Brooke, "which deservedly maintains so high a reputation, is found in the greatest plenty all over the North; a providential circumstance for the inhabitants, from the salubrious qualities it possesses *."

* Brooke's Sweden, p. 197. 


\section{BUTCHER'S BROOM.}

\section{RUSCUS.}

Botanists are doubtful of the origin of the word Ruscus: Miller supposes it to be from Rusticus-a rustic plant, because, says he, the countrymen, in old times, used to lay it on their meat to defend it from mice.-French, le Houx frelon, Buis piquant, Fragon piquant.-Italian, Rusco, Pontogopi.-English, Knee-holm, Kneehulven, or Knee-holly, Wild Myrtle, and Prickly Pettigree.

The Prickly Butcher's-Broom, Ruscus aculeatus, is a native of the south of Europe, of Asia, and Africa; in England, it is not uncommon in the woods and thickets, but does not grow in the northern counties. The leaves are very like those of the myrtle, but stiff, and ending in sharp prickly points. These leaves are very singular in their construction, and as the flowers are borne upon their face, it is a disputed point amongst botanists whether they are truly leaves; as some consider the plant to be, like dodder and a few others, leafless, and the apparent leaves to be winged footstalks of the flowers, or else expanded branches. It is, in fact, one of those singular cases on which as much may be said on one side as on the other. The flower is of a yellow green, or sometimes tinged with purple; it blossoms in March and April, and the seeds ripen in winter.

The green shoots tied up in bundles are sold to the butchers for sweeping their blocks: hence their familiar appellation. In Italy, they are made into besoms; and the hucksters there place the boughs round their bacon 
and cheese, to defend them from mice. The young shoots gathered in spring are sometimes eaten by the poor, in the manner of asparagus.

When planted under trees and shrubs, it spreads into large clumps, and retaining the leaves all the winter, has a good effect.

The thick leaved species, Ruscus hypophyllus, is a native of Italy and of Africa; it flowers in May and June: the double leaved, Ruscus hypoglossus, with pale yellow flowers, is in blossom a month earlier; it grows naturally in Italy, Hungary, and Africa.

The branches of these shrubs in winter, when laden with the ripe red berries, are very handsome; they keep fresh a long time in water, and were formerly much used to adorn chimney-pieces, \&c. 


\section{BUTTON WOOD.}

\section{CEPHALAN'THUS.}

RUBIACEE.

TETRANDRIA MONOGYNIA.

The botanical name of this tree is derived from two Greek words, and signifies Head-flower, Button-wood, Button-tree, Pond-dogwood.-French, bois à boutons; Italian, cefalanto.

The American Button-wood was introduced here in 1735, by Peter Collinson, Esq. In this country it grows six or seven feet high; the leaves are nearly three inches long, and about an inch and a quarter wide, having a strong vein longitudinally through the middle, and several smaller veins running from thence to the borders; they are of a light green, and the footstalks near the branches are frequently tinged with red. The ends of the branches are terminated by loose spikes of spherical heads, about the size of a marble, which are composed of many small pale yellow flowers, fastened to an axis in the middle; these appear in July, and in warm seasons are succeeded by seeds, which sometimes ripen in England. 


\section{CAROB TREE.}

\section{CERATONIA SILIQUA.}

Also called St. John's Bread, and by some old writers, Beantree.-French, caroubier; Italian, carubbo.

The Carob-tree grows to a considerable size, with many branches; the leaves are pinnate, composed of thick stiff leaflets, nearly round, two or three inches in diameter. The blossoms grow in little red clusters with yellow stalks; these are succeeded by legumes an inch and a half broad, and from four to fourteen inches in length, which contain several flat seeds; the husks are filled with a sweet juice.

In Palestine, Greece, Italy, Barbary, \&c., where this tree is very common, the fruit is suffered to ripen and grow dry upon the trees. The poor in those countries feed upon it, and it is also used to fatten cattle.

Many persons have supposed the locusts eaten by St. John the Baptist to have been the fruit of this tree, and that the wild honey was the pulpy juice contained in the husk; whence the tree has obtained the name of St. John's Bread. This notion, however, is generally considered as fabulous; but many writers agree that there is great reason to believe these to be the husks of which the Prodigal Son desired to partake with the swine. Columella, and other authors, speak of them as a common food for swine, and as being frequently eaten by the poor. 
The Carob-tree has been cultivated in England since $15 \% 0$; it endures our ordinary winters very well, but requires some little protection in severe seasons. Gerarde speaks of it as newly sown in his garden, and promising well. 


\section{CAROLINA ALILSPICE.}

\section{CALYCANTHUS FLORIDUS.}

Calycanthus is derived from two Greek words, signifying calyx and flower; some persons considering the petals of the blossom as mere calycine leafiets. - French, calycanth, le pampadour.-Italian, pampadurra.

In its native country this shrub will grow nine or ten feet high, but in England its height seldom exceeds four feet. It divides near the ground into many slender branches, covered with a brown aromatic bark, with $t$ leaves placed opposite at every joint. The flowers grow on short footstalks at the ends of the branches; their colour is a dingy purple, and their scent by no means agreeable: they blow in May.

The inhabitants of Carolina gave it the name of Carolina Allspice, from the aromatic scent of its bark. It was introduced here by Mr. Catesby, in 1726, but was very scarce till the year $175 \%$.

There are two varieties, the long-leaved, and the round-leaved. 


\section{CASSIA.}

The derivation of the word is uncertain.

Most of these plants require artificial heat in this country, but the Maryland Cassia, Cassia Marilandica, in a dry soil and not too much exposed, will live abroad. It grows four or five feet high, the blossoms are of a pale yellow, and grow in loose spikes. It is a native of North America.

The senna of the apothecaries is obtained from an Egyptian plant belonging to this genus.

The poets' Cassia is of another genus, (Osyris alba): it has been asked why the epithet alba has been given to this plant, the flowers being yellow, and the berries red. The Cassia is described by the poets as white :-

" A dimpled hand,

Fair as some wonder out of fairy-land, Hung from his shoulder: like the drooping flowers Of whitest Cassia, fresh from summer showers."

Keats's Poems, p. 24

Some have supposed the true Cassia to be the Cneorum, but that also has yellow blossoms; others have believed that the Romans had two sorts of Cassia, one of which was the Cneorum, and the other a species of wild cinnamon. In this case, the white blossom is understood, but not the reason for calling the Usyris alba. 
Mr. Keats expressly contrasts the blossom of the Cassia with that of the Laburnum:

"Where the dark-leaved laburnum's drooping clusters Reflect athwart the stream their yellow lustres; And, intertwined, the Cassia's arms unite With its own drooping buds, but very white." Keats's Early Poems, p. 55. 


\section{CA'TALPA.}

CATALPA SYRINGIFOLIA.

BIGNONIEE.

DIDYNAMIA ANGIOSPERMIA.

This genus was named Bignonia by Tournefort, in compliment to Abbé Bignon, librarian to Louis the Fourteenth.-French, catalpe; Italian, catalpa.

The Catalpa is a deciduous tree, rising with an upright stem to the height of forty feet; it has many lateral branches, on which the leaves are placed opposite, at every joint: they are heart-shaped. The flowers grow in large branching panicles, towards the ends of the branches; they are of a dingy white, with a few purple spots, and faint stripes of yellow on the inside: these open in August, and are succeeded by long taper pods; but it does not produce the fruit in this country.

This tree was found by Mr. Catesby, in South Carolina, at a great distance from the English settlements; and brought to England in the year 1726. It is now not uncommon in our nurseries and plantations. In this climate the leaves come out very late; which, before the tree was well understood, has often led persons to think them dead, and even to cut them down on that supposition.

The branches dye wool a kind of cinnamon colour. Thunberg says, the Japonese consider the leaves as beneficial to the nerves, and lay them on any part of the body affected with pain, as a cure for it. 


\section{CEDAR TREE.}

PINUS CEDRUS.

French, cedre; Italian, cedro.

THis tree was formerly placed with the larch, with which it agrees in foliation; now both are included in the pine genus, with which the Cedar agrees in being an evergreen.

"6 That noble tree, the Cedar of Lebanon," says Martyn, in his edition of Miller, "has a general striking character of growth so peculiar to itself, that no other tree can possibly be mistaken for it."

"T Those which seem of the greatest antiquity," observes Evelyn, "are indeed majestical. The sturdy arms grow in time so weighty as often to bend the very stem and main-shaft. The leaves much resemble those of the larch, but are somewhat longer, and closer set, erect, and perpetually green; which those of the larch are not, but hanging down, dropping off, and deserting the tree in winter. The cones are tacked and ranged between the branch-leaves, in such order as nothing appears more curious and artificial, and at a little distance exceedingly beautiful; these cones have the bases rounder, shorter, or rather, thicker, and with blunter points; the whole circumzoned as it were, with pretty broad thick scales, which adhere together in exact series to the very summit, where they are somewhat smaller; but the entire lori- 
cation smoother couched than those of the fir; within these repositories, under the scales, nestle the small nutting seeds, of a pear shape. These cones grow upon the upper part of the branches, and stand erect, having a strong, woody, central style, by which they are firmly annexed to the branch, so as with difficulty to be taken off; which central style remains upon the branch after the cone is fallen to pieces, for it never drops off whole, as those of the pines do."

Many wonderful properties are ascribed to the wood of this celebrated tree; such as its resisting putrefaction, destroying noxiousinsects, \&c.; continuing one, or, as some say, two thousand years sound; yielding an oil famous for preserving writings; purifying the air by its effluvia; and, when used in wainsceting churches or chapels, inspiring the worshippers with a solemn awe. It was formerly used in embalming the dead.

Evelyn, speaking of the timber, which, he says, is proof against all putrefaction, above all other ingredients or compositions of embalmers; adds " and ihat by a pretty contradiction, giving life as it were to the dead, and destroying the worms which are living; and, as it does where any goods are kept in chests or presses of the wood, excepting woollen cloth and furs, which it is observed they corrupt. Whatever other property this noble tree is deservedly famous for, it is said to yield an oil, which, above all other, best preserves the monuments of the learned,--books and writings."

Many things are recorded of this wood, with regard to its length of duration; it is said, that in the Temple of Apollo, at Utica, some was found that was two thousand years old; and at Legunti, in Spain, a beam was discovered in an oratory consecrated to Diana, which was 
brought to Zante two centuries before the destruction of Troy; that Sesostris built a vessel of Cedar of two hundred and eighty cubits; and that the statue of the goddess in the famous Ephesian temple, as well as most of the wood-work of that glorious structure, was of that material.

Gerarde remarks, that "the Gentiles were wont to make their devils or images of this kind of wood, that they might last the longer."

Martyn observes, that there has been great confusion of the Cedar of Lebanon with other trees also bearing the name of Cedar ; and that, as to the material used in the heathen temples, it is very uncertain. But in building the sumptuous temple and palace of Solomon at Jerusalem, we have, as he says, better authority:-

"And Solomon sent unto Hiram, saying,

"Now therefore command thou that they hew me cedar trees out of Lebanon.

"And Hiram sent to Solomon, saying,

"I will do all thy desire concerning timber of cedar, and concerning timber of fir. My servants shall bring them down from Lebanon unto the sea.

"And I will convey them by sea, in floats, unto the place that thou shalt appoint me, and will cause them to be discharged there, and thou shalt receive them.

"And thou shalt accomplish my desire in giving food for my household. So Hiram gave Solomon cedar-trees, and fir-trees, according to all his desire *."

"And King Solomon raised a levy out of all Israel; and the levy was thirty thousand men.

"And he sent them to Iebanon, ten thousand a month, by courses; a month they were in Lebanon, and two months at home. 
"And Solomon had threescore and ten thousand that bare burdens, and fourscore thousand hewers in the mountains *."

"So he built the house and finished it, and covered the house with beams and boards of cedar.

"And then he built chambers against all the house, five cubits high; and they rested on the house with timber of cedar $\uparrow . "$

"And the cedar of the house within was carved with knops and open flowers : all was cedar, there was no stone seen.

"And he built the inner court with three rows of hewed stone, and a row of cedar beams \$."

"Solomon built also the house of the Forest of Lebanon, . . . . upon four rows of cedar pillars, with cedar beams upon the pillars.

"And the porch of judgment was covered with cedar from one side of the fioor to the other $\S . "$

"What we find mentioned in the Scriptures, of the lofty cedar," says Miller, " can be no ways applicable to the stature of this tree, since, from the experience we have of those now growing in England, as also from the testimony of several travellers who have visited those few remaining trees on Mount Libanus, they are not inclined to grow very lofty, but, on the contrary, extend their branches very far: to which the allusion made by the Psalmist agrees very well, when he is describing the flourishing state of a people, and says, they shall spread their branches like the cedar-tree."

Martyn, referring to this passage, says, "the allusion of the Psalmist, of spreading abroad like a Cedar in Lebanon, shows that he was well acquainted with this tree, which is remarkable for the wide spread of its branches,

* 1 Kings, chap. v. verses $13-15$.

$+\quad$ Chap. vi. verses 9 and 10 .

$\ddagger \quad$ Verses 18 and 36 .

$\S \quad$ Chap. vii. verses 2 and 7. 
rather than for its height. Had Milton known it as well, he would not have used the expression of the

"Insuperable height of loftiest shade-"

in speaking of the cedar."

But do the trees here described by Milton necessarily stand on level ground? does he not rather appear to describe a steep rising ground, well clothed with trees, showing their heads in ranks? -

"So on he fares, and to the border comes Of Eden, where delicious Paradise, Now nearer, crowns with her enclosure green, As with a rural mound, the champain head Of a steep wilderness, whose hairy sides With thicket overgrown, grotesque and wild, Access denied; and over head up-grew Insuperable height of loftiest shade, Cedar, and pine, and fir, and branching palmA sylvan scene: and, as the ranks ascend Shade above shade, a woody theatre Of stateliest view. Yet higher than their tops The verdurous wall of Paradise up-sprung: Which to our general sire gave prospect large Into his nether empire neighbouring round. And higher than that wall, a circling row Of goodliest trees, loaden with fairest fruit, Blossoms and fruits at once of golden hue Appeared, with gay enamelled colours mixed: On which the sun more glad impressed his beams Than in fair evening cloud, or humid bow, When God hath showered the earth; so lovely seemed That landskip."

Paradise Lost, book iv.

In another passage, too, he describes " the garden of God, with cedars crowned Above all hills.' 
There are various passages in Scripture which bear allusion to the luxuriant growth of the Cedar. The Psalmist, likening the church to a fair spreading vine, says-

"The hills were covered with the shadow of it, and the boughs thereof were like the goodly cedars.

"She sent out her boughs unto the sea, and her branches unto the river *."

\section{Again :--}

"The righteous shall flourish like the palm-tree; he shall grow like a cedar in Lebanon.

"Those that be planted in the house of the Lord shall flourish in the courts of our God. They shall still bring forth fruit in old age; they shall be fat and flourishing.$+ "$

"The trees of the Lord are full of sap, the cedars of Lebanon which he hath planted $\ddagger . "$

In Ezekiel, where the power of God to raise the humble and to lower those in power is described by a parable, is the following passage:-

"Thus saith the Lord God, I will also take of the highest branch of the high cedar, and will set it; I will crop off from the top of his young twigs a tender one, and will plant it upon an high mountain and eminent.

"In the mountain of the height of Israel will I plant it, and it shall bring forth boughs, and bear fruit, and be a goodly cedar §."

This last passage particularly bears reference to the height of the cedar; as does also the following:

"Yet destroyed I the Amorite before them; whose height was like the height of the cedars, and he was strong as the oaks II."

* Psalm lxxx. 10, 11.

† Psalm civ. 16 .

II Amos, chap. ii. verse 9.
† Psalm xcii. 12, 13, 14.

§ Ezekiel, xvii. 22, 23. 
Again, mention is made of

"The cedars of Lebanon, that are high and lifted up*."

Miller observes, that it is remarkable that, as far as has come to our knowledge, the Cedar should not be found as a native of any other part of the world than Mount Lebanon; but Martyn, in a later edition of Miller's Dictionary, says, "it is not only found on Mount Lebanon, but Belon observed it on the mountains of Amanus and Taurus."

Few of the trees now remain on Mount Lebanon; nor is it likely there should remain many, after the industrious felling of fourscore thousand hewers employed there.

"The spreading Cedar that an age had stood, Supreme of trees, and mistress of the wood, Cut down and carved, my shining roof adorns :

And Lebanon his ruined honour mourns."

\section{Prior's Solomon.}

Ranwolff, in 15\%5, saw cnly twenty-four sound trees, and two which were old and decayed. "We found ourselves," says he, "upon the highest point of the mountain, and saw nothing higher, but only a small hill before us all covered with snow, at the bottom whereof the high Cedar-trees were standing. And though this hill hath in former ages been quite covered with Cedar-trees, yet they are since so decreased, that I could tell no more but twentyfour that stood round about in a circle; and two others, the branches whereof are quite decayed for age. I also went about in this place to look for some young ones, but could find none at all. These trees are green all the year long, have strong stems that are several fathoms about, and are as high as our fir-trees."

* Isaiah, chap. ii. verse 13. 
A hundred and twenty-one years after the time of which this traveller speaks, Maundrell reckons only sixteen large trees, but mentions sereral small ones. $\mathrm{He}$ says, that having proceeded for three hours across the plain of Tripoli, he arrived at the foot of Libanus, which continually ascending, with some fatigue, he came, in four hours and a half, to a small village called Eden; and in two hours and a half more to the Cedars. "These noble trees," continues he, "grow amongst the snow, near the highest part of Libanus, and are remarkable, as well for their own age and largeness, as for the frequent allusions made to them in the Word of God. Here are some very old, and of a prodigious bulk, and others younger, of a smaller size. Of the former, I could reckon up only sixteen; the latter are very numerous. I measured one of the largest, and found it tweive yards six inches in girth, and yet sound; and thirty-seven yards in the spread of its boughs. At about five or six yards from the ground, it was divided into five limbs, each of which was equal to a great tree*."

The traveller Le Bruyn reckons about five or six-andthirty trees remaining on Mount Libanus when he was there, and would insinuate that it is not easy to count them; as it has been said of the stones at Stonehenge.

"It is a folly," says Thevenot, " to say, that when the cedars of Mount Lebanon are counted several times, their number is found each time to vary; for there are in all but twenty-three, great and small $\uparrow$."

This author went there about eighty years after Ranwolff, who counted six-and-twenty ; and forty years

* Maundrell's Journey from Aleppo to Jerusalem, page 142

+ Thevenot's Voyage du Levant, in 1655 ; part i. p. 443 ; edition 1664 . 
before Maundrell, who reckoned sixteen, besides a few small ones.

The few trees yet left on Mount Lebanon are preserved with a religious strictness. On the day of the Transfiguration, the patriarch repairs in procession to these trees, and celebrates the festival called the Feast of Cedars.

There is little doubt but these trees are now far more numerous in England than in their native place. Miller expresses surprise that the cultivation of the Cedar was so long neglected in this country, when it would be so ornamental on barren and bleak mountains; where few others would flourish so well as this, which is a native of the colder parts of Mount Libanus, where the snow lies nearly all the year. "That these trees are of quick growth," continues he, "is evident from four of them in the Botanic Garden at Chelsea, which, as I have been credibly informed, were planted there in the year 1683, and at that time were not above three feet high. Two of these trees were, in 1\%66, upwards of twelve feet and a half in girth, at two feet above the ground, and their branches extended more than twenty feet on every side their trunks; which branches, though they were produced twelve or fourteen feet above the surface, did, at every termination, hang very near the ground, and thereby afford a goodly shade in the hottest season of the year."

In another passage, he describes the character of their growth in a more particular manner :- " These trees are by many people kept as pyramids, and sheared as yews, \&c., in which form they lose their greatest beauty; for the extension of the branches is very singular in this tree-the ends of the shoots for the most part declining, and thereby showing their upper surface; which is constantly clothed with green leaves in so regular a manner, 
as to appear at some distance like a green carpet, and there waving about with the winds, make one of the most agreeable prospects that can be to terminate a vista, especially if planted on a rising ground."

When once the Cedar-tree has left the nursery, no knife or hatchet must be suffered to touch it; even the lopping of the lowest branches is injurious, both retarding the growth and diminishing the beauty.

The trees just mentioned as growing in the Botanic Garden at Chelsea were planted in a lean hungry sand mixed with gravel, to the depth of about two feet; beyond which, the soil is a hard rocky gravel. They stood at the four corners of a pond, bricked up within two feet of their trunks, so that their roots having no room to spread on one side, were cramped in their growth; but it is supposed they were as much benefited by their vicinity to the water, as injured by the confinement of the roots.

Mr. Martyn observes upon this, that probably the roots, finding themselves stopped by the brick walls, tended downwards, and spread themselves in the moist earth under the water, which greatly promoted the growth of the trees; for, upon this pond being filled up, these noble trees decayed, and were quickly ruined for want of their accustomed beverage.

In the Scriptures the Cedar is spoken of as flourishing near the water, where the greatness and glory of Assyria is likened unto a Cedar-tree. It is thus described :

"Behold the Assyrian was a cedar in Lebanon, with fair branches, and with a shadowing shroud, and of an high stature; and his top was among the thick boughs.

"The waters made him great, the deep set him up on high, with her rivers running round about his plants, and sent out her little rivers unto all the trees of the field. 
"Therefore his height was exalted above all the trees of the field, and his boughs were multiplied, and his branches became long, because of the multitude of the waters when he shot forth."

"All the fowls of heaven made their nests in his boughs, and under his branches did all the beasts of the field bring forth their young, and under his shadow dwelt all great nations.

"Thus was he fair in his greatness, in the length of his branches, for his root was by great waters.

"The cedars in the garden of God could not hide him; the fir trees were not like his boughs, and the chestnut trees were not like his branches; nor any tree in the garden of God was like unto him in his beauty.

"I have made him fair by the multitude of his branches, so that all the trees of Eden that were in the garden of God envied him*."

Neither Turner, Parkinson, nor Gerarde, speak of the Cedar as growing here. Mr. Evelyn says, it was not cultivated here in 1664; he expresses himself warmly on the subject, and probably may have assisted in turning the planter's attention to it. He says he received cones and seeds of the few remaining trees on Lebanon; "and why they should not thrive in Old England," continues he, "I know not, save for want of industry and trial."

In the gardens of the old manor-house at Enfield in $16 \%$, when it was cccupied by Robert Uvedale, LL.D. who kept a flourishing school there, among other curious trees he planted a Cedar. In the year 1788, an account of this tree was published in the Gentleman's Magazine; where it is described as being forty-five feet nine inches in height, eight feet having been broken from the top by the hurricane in 1703; and at the largest part, it measured fourteen feet six inches in circumference.

Many other Cedars of considerable size have been scattered about in different parts of the kingdom. Some of the finest were planted by Archibald Duke of Argyle;

* Ezekiel, chap. xxxi, verses 3, 4, 5, 6, 7, 8, 9. 
of which one of the most remarkable was destroyed by a hurricane on the 1st of January 17\%9. It grew on the north side of Hendon-place, in Middlesex; its height was seventy feet; the diameter of the horizontal extent of the branches was one hundred feet; the circumference of the trunk, at the largest part, twenty-one feet. It began to branch about twelve feet from the ground; and the limbs, of which there were ten, measured from six feet to twelve in circumference. This tree is supposed to have been two hundred years old, and tradition says, it was planted by Elizabeth herself: but as Martyn justly observes, "tradition is seldom to be depended upon, and Queen Elizabeth is a great favourite with traditionmongers. Is it probable," continues he, "if such a tree had existed in 15\%9, that Gerarde, Parkinson, and Evelyn should know nothing of it? When blown down it was perfectly sound, and seemed as if not grown to maturity ; it is probable therefore that it was not two hundred years old, for the Cedars at Chelsea attained their full size, and decayed, in less than a century."

There is little strength in this argument, for it has just been observed, that the growth of those trees was accelerated by their vicinity to a pond, and their decay by the filling up of the pond.

Dr. Hunter describes a fine Cedar growing at Hillington, near Uxbridge, supposed at that time to be aged one hundred and sixteen years.

"The only relic of Dr. James Sherard's famous botanic garden at Eltham," observes Martyn, "so elegantly displayed by Dillenius, is a Cedar of Lebanon, which girts nine feet at three feet from the ground."

Mortimer, in his Art of Husbandry (1708), affirms, that he had raised several Cedars from cones which he 
had from Lebanon, and that he then had a walk planted with them. It was not until 1730 that the seeds ripened in England, which they do now in a manner to leave no fear of supply, without having cones from Lebanon. It has been observed, that they ripen better in severe seasons than in mild ones.

The Cedar-wood, commonly known by that name in England, is not from this tree, but is that of the Bermudas Cedar, or Bermudas Juniper, Juniperus Bermudiana.

Notwithstanding the objections made against Milton, on that head, the Cedar has been generally characterized by the poets as a lofty tree:-

" So when Jove's bird on some tall cedar's head Has a new race of generous eaglets bred, While yet unplumed within the nest they lie, Wary she turns them to the eastern sky:

Then if, unequal to the god of day,

Abashed they shrink and shun the potent ray, She spurns them forth and casts them quite away;

But if with daring eyes unmoved they gaze, Withstand the light and bear the golden blaze, Tender she broods them with a parent's love The future servants of her master Jove."

Rowe's Lucan, book ix.

"No tree that is of count in greenwood grows, From lowest juniper to cedar tall, No flower in field that dainty odour throws And decks his branch with blossoms over all, But there was planted, or grew natural."

Spenser.

Spenser, in his Visions of the World's Vanity, supposes one of these noble Cedars destroyed by a little worm:

"High on a hill a goodly cedar grew,

Of wondrous length and straight proportion, 
That far abroad her ciainty odours threw ;

'Mongst all the daughters of proud Lebanon,

Her match in beauty was not any one.

Shortly, within her inmost pith there bred

A little wicked worm

Solomon makes this honest confession :

"The vegetable world, each plant and tree,

Its seed, its name, its nature, its degree,

I am allowed, as Fame reports, to know ;

From the fair cedar, on the craggy brow

Of Lebanon, nodding supremely tall,

To creeping moss and hyssop on the wall-

Yet, just and conscious to myself, I find

A thousand doubts oppose the searching mind.'

PRIOR.

The Cedar is usually described either as lofty, farspreading, straight, or as a sacred tree :

"Cedars here,

Coeval with the sky-crowned mountain's self, Spread wide their giant arms."

Mason.

"The cedar, whose top mates the highest cloud, Whilst his old father Lebanon grows proud Of such a child, and his vast body laid Out many a mile, enjoys the filial shade."

Churchill.

"Bear me, Pomona! to thy citron groves; To where the lemon and the piercing lime, With the deep orange, glowing through the green, Their lighter glories blend. Lay me reclined Beneath the spreading tamarind, that shakes, Fanned by the breeze, its fever-cooling fruit. Deep in the night the massy locust sheds, 
Quench my hot limbs; or lead me through the maze, Embowering endless, of the Indian fig.

Or thrown at gayer ease, on some fair brow, Let me behold, by breezy murmurs cooled, Broad o'er my head the verdant cedar wave, And high palmettos lift their graceful shade."

Thomson: Summer.

Shakespeare makes Cranmer say of King James, in anticipation of his birth-

" he shall flourish,

And like a mountain cedar, reach his branches

To all the plains about him :"

But this passage, which occurs in the last scene of Henry the Eighth, is by some persons supposed to have been added by Ben Jonson after the accession of James.

"On high the cedar

Stoops, like a monarch to his people bending,

And casts his sweets around him."

B. Corvwall.

Armstrong, speaking of the cooling fruits and generous shades afforded to the inhabitants of hot climates, says -

"The breeze, eternal breathing round their limbs,

Supports in else intolerable air ;

While the cool palm, the plantain, and the grove

That waves on gloomy Lebanon, assuage

The torrid hell that beams upon their heads."

The idea of Lebanon is ever connected with that of the Cedar, for which it is celebrated :

"Long have they viewed from far with wishing eyes

Our fruitful vales, our fig-trees, olives, vines,

Our cedars, palms, and all the verdant wealth

That crowns fair Lebanon's aspiring brow." 
" Now upon Syria's land of roses Softly the light of eve reposes, And, like a glory, the broad sun Hangs over sainted Lebanon ; Whose head in wintry grandeur towers, And whitens with eternal sleet, While summer, in a vale of flowers, Is sleeping rosy at his feet."

Moore's Paradise and the Peri.

"Down in a vale where lucid waters strayed And mountain-cedars stretched their downward shade."

Montgomery.

Moore, in his Lallah Rookh, quotes a passage from Dandini, in which he says that the rivulet of Mount Lebanon is called the Holy River, from the "cedarsaints" among which it rises-

"One of that ancient hero line

Along whose glorious current shine

Names that have sanctified their blood;

As Lebanon's small mountain-flood

Is rendered holy by the ranks

Of sainted cedars on its banks!"

But in a note at the end of the volume, the poet tells us a different cause has been assigned for giving this stream the epithet Holy: "In these are deep caverns, which formerly served as so many cells for a great number of recluses, who had chosen these retreats as the only witnesses upon earth of the severity of their penance. The tears of these pious penitents gave the river of which we have just treated the name of the Holy River." (See Chateaubriand's Beauties of Christianity.)

Sir Philip Sidney compares the Cedar to a lady of dignified carriage- 
"But to the cedar, Queene of woods, when I lift my be-teared eyes,

Then do I shape to myselfe that forme which raigns so within me,

And thinke there she doth dwell, and heare what plaints I do utter :

When that noble top doth nod, I believe she salutes me;

When by the wind it maketh a noyse I doe think she doth answer."

Book 1st.

The passage is too long, to give the whole of it; for the rerses of that illustrious man are not the most poetica parts of his writings. In another part of this rolume, he alludes to the proverbial straightness of the Cedar:

"As sweet as riolets, faire as a lilly is, Streight as a cedar

Book 2d.

This passage also has reference to the person of the lady the singer celebrates. Shakespeare makes a similar comparison, in Lore's Labour Lost, where Dumain comes in praising his mistress: "the wonder of a mortal eye :" he says she is "as upright as the cedar."

Shakespeare frequently mentions the Cedar : in Henry the Sixth, the $2 d$ part, Warwick says, in answer to Clifford-

"This day I'll wear aloft my burgonet

(As on a mountain-top the cedar shews

That keeps its leaves in spite of any storm),

E'en to affright thee with the view thereof."

According to Massinger, howerer, it is not so tenacious of its roots :

"Cedars, once shaken with a storm, their own Weight grubs their roots out."

ITaid of Honour, Act $3 \mathrm{~d}$, Scene 1st. 
Fairfax designates the Cedar as proud, in reference, probably, to its erect growth:

"Proud cedar ; oak, the king of forests crowned."

Spenser, too, names it, "The cedar proud and tall." Drayton terms it, " The tufted Cedar." 


\section{CELAS'TRUS.}

French, bourreau des arbres; Italian, celastre. It is sometimes familiarly called Staff-tree; being called Celastrus from an evergreen shrub so named by Theophrastus, and described by him as fit for no use but to make staves for old men*.

The Celastrus bullatus in many parts of North America, where it grows naturally, rises to a height of nine or ten feet, but in this country it seldom exceeds five. Several stems grow from one root, and these again divide into many branches, covered with a brown bark, and clothed with leaves about three inches long, and two broad: the flowers grow in loose spikes at the ends of the branches; they are white, and blow in July. This shrub rarely ripens seed in England.

The Celastrus scandens, or Climbing Staff-tree, has very flexible stalks, which wind round each other, or round any tree or shrub that happens to be near, to the height of fourteen feet, or more; binding the trees to which it clings so tight as sometimes to destroy them. The leaves are of a lively green on the upper surface, but much paler beneath; the flowers make little show, but the fruit is, when ripe, very ornamental, being then of a bright red. It flowers in June, and the seeds ripen in autumn.

* Johnson, the editor of Gerarde's Herbal, supposes the Celastrus of Theophrastus to have been the evergreen privet, and therefore gives it as onc of the names of that shrub. 
Thunberg observed a species of the Celastrus in Japan, which for the singular appearance of its winged branches, he named the Celastrus alatus; he describes it as a handsome shrub, and observes, that it is commonly cultivated in the gardens of the Japonese. The young men hang branches of the flowers over the doors of a house, when they would signify their desire to pay addresses to a young woman within*.

* Thunberg's Travels, vol. iii. p. 84 . 


\section{COLUTEA.}

LEGUMINOSA.

DIADELPHIA DECANDRIA.

The derivation of the name is uncertain: it is sometimes called Bladder Senna French, baguenaudier; Italian, colutea.

The common Colutea, Coluter arborescens, has several stems, which grow twelve or fourteen feet high, and divide into many branches clothed with leaves, four or five lobed on each side, with an odd one at the end, each lobe indented in the form of a heart; they are of a grayish colour. 'The flowers are pea-shaped, or as the botanists term it papilionaceous, butterfly-shaped; they are yellow, and grow two or three together, on a footstalk two inches long, rising from the axils of the leaves.

It is a native of Italy, Carniola, the south of France, and the warmer parts of Switzerland; it has been found on Mount Vesuvius, even in the ascent to the crater, where were few other plants: with us it flowers from June to August. The leaves have been used as a substitute for those of senna; which, with the form of the seed-vessel, has obtained it the name of Bladder Senna. It is said to afford a food grateful to cattle; it was cultivated in England in the year 15\%0. Mr. Curtis observes, that a wet soil is fatal to it. Miller recommends gardeners to suspend lobsters' claws or the bowls of tobacco-pipes on different parts of these sirubs to entice the earwigs, which are apt to nestle within the bladders and destroy the seeds. 
Gerarde says, if any of the branches be carelessly broken off, and as negligently stuck into the ground, it will take root and prosper, at whatever time of the year it be done.

The Oriental Bladder Senna, Colutea cruenta, is not more than half the height of the former, the flowers are smaller, of a red colour, marked with yellow; they blow in June. This was discovered in the Levant, by Tournefort, and cultivated by Miller in 1731 .

Pococke's Colutea, Colutea Pococki, is also from the Levant-the seeds were first brought to England by Dr. Pococke; it was cultivated by Miller in 1752. The height of this is similar to the last-mentioned shrub; the flowers are yellow, and appear a month earlier than the other sorts; there is also a constant succession of them till late in the autumn.

These shrubs make a pretty variety among other flowering shrubs, from the singular appearance of the pods and flowers; but unless sheltered by other trees, the branches are apt to be to torn, and disfigured by the wind. 


\title{
CHESTNUT TREE.
}

\author{
CASTANEA VESCA.
}

CORYLIDEÆ.

MONCCIA POLYANDRIA.

The old botanical name for this tree was Castanea, from a town in Thessaly about which it grew in great abundance; Linnæus placed it in the same genus with the beech, but later botanists have restored its ancient name, and separated it from the beech.French, chataignier; Italian, castagno.

The Chestnut, where it has room, will grow to an enormous size, and spread its branches freely to a great distance on every side; but where it is confined, it runs up to a considerable height, and is of much smaller bulk. The leaves are large, of a lucid green, four or five inches long, and two in width; somewhat wrinkled, and marked with several transverse veins, proceeding from a strong midrib. The blossoms grow in little balls, without any foot-stalk, and the calyx becomes the capsule or case which contains the nuts.

"6 The Chestnut in maturity," says Mr. Gilpin, 66 is a noble tree, and grows not unlike the oak."

" Being planted in hedge-rows," says Evelyn; " or for avenues to our country-houses, they are a magnificent and royal ornament."

It is commonly called the Spanish Chestnut in this country; either because it came to us from Spain, or because the fruit, which grows to great perfection in that warm climate, is brought from thence. The nuts are 
but small that grow in England, and are generally left for the hogs and squirrels.

Some say that the Chestnut is indigenous of this country. Evelyn strongly supports this opinion; he says, he had once a large barn near London, formed entirely of its timber, "and certainly," continues he, "the trees grew not far off, probably in some wood near the town, for in that description of London written by FitzStephens, in the reign of Henry the Second, he speaks of a very noble and large forest which grew to the north of it. And yet some will not allow the Chestnut to be a free-born of this island, but of that I have little doubt."

Dr. Ducarel is of the same opinion; in support of which, he appeals to the ancient records, among which he finds a deed of gift from Henry the Second to Flexley Abbey, of the tithe of all his Chestnuts in the Forest of Dean.

Miller remarks, that it was formerly in greater plenty in England than of late years: " as may be proved," says he, " by the old buildings, which were for the most part of this timber ; and there are decayed old Chestnuts in the woods and chases about London, particularly Enfield Chase."

Martyn does not support these claims, but doubts whether the timber in our old buildings, supposed by Miller and others to be Chestnut, be not oak of an inferior quality.

This tree is a native of many parts of Asia, China, Cochin China, Japan, \&c. and is naturalized in most countries of the south of Europe. It is said that Tiberius Cæsar first brought it from Sardis in Lydia to Italy, whence it was carried to other parts of Europe.

It has been observed, that the Chestnut makes a 
frequent and a handsome figure in the landscapes of Salvator Rosa.

It is a very long-lived tree, and there are several individuals remarkable for their large growth. The famous Castagno di cento Cavalli on Mount Etna, as measured by $\mathrm{Mr}$. Brydone in $\mathbf{1 7 \% 0}$, is two hundred and four feet in circumference: some indeed have doubted whether this be really one tree, and Brydone himself thought there might have been, from the appearance, five trees; but he was assured the space had formerly been filled with solid timber, and there was certainly no bark on the inside. One person professed to have dug the earth from the roots, and ascertained by them that there was one tree only. "I alleged," says the author, "that so extraordinary an object must have been mentioned by riany of their writers : he told me that it had, and produced several examples." He says that Massa, one of their most esteemed authors, says of a Chestnut-tree, which may probably be the tree in question, that the hollow of it contained three hundred sheep, and thirty people on horseback had often been in it at a time. Brydone quotes the following lines on this subject from Bogolini :

"Supremos inter montes monstrosior omni

Monstrosi fœtum stipitis $\mathbb{E}$ tna dedit,

Castaneam genuit, cujus modo concava cortex

Turmam equitum haud parvum continet, atque greges *."

Il Castagno del Galea measured serenty-six feet round, at two feet from the ground. "It rises from one solid stem to a considerable height, after which it branches out, and is a much finer object than the other." He mentions a third, of nearly the same size, called Il Castagno del

* Brydone's 'Tour through Sicily and Malta, letter 6 . 
Nava. The extraordinary size of these trees may be in some measure owing to the rich soil formed from the ashes of the rolcano. Dr. Clarke, in his Travels in Sweden, observes, that some plants will grow and thrive in an extraordinary manner, in those parts of the forests where the trees have been consumed by fire.

Captain Smith, who visited Mount Etna eight or ten years since, says, "That father of the forest, the renerable Castagno di cento Cavalli, supposed to be the oldest tree in the world, appears to consist of five large and two smaller trees; which, from the circumstance of the bark and boughs being all outside, are considered to have been one trunk originally. Some say the two smaller ones are saplings, planted purposely to complete the circle: the peasants strongly affirmed that the roots, having been inspected, were found to be in common, but not having had the means or permission myself of examining further into the fact, I could not form a decided opinion. The largest trunk is thirty-eight feet in circumference, and the circuit of the whole five, measured just above the ground, is one hundred and sixty-three feet. It still bears rich foliage, and much small fruit, though the heart of the trunks is decayed, and a public road leads through them. Some other trees of the same species, and of a very large size, are spread over the adjacent grounds *."

There is a great difference in the measurement of Captain Smith and Mr. Brydone's; no less than fortyone feet: yet it is not likely that Mr. Brydone should have been mistaken in his calculation, as his friend Mr. Glover, who was with him, measured it also, and

* Sicily and its Islands, by Captain Smith, R. N. p. 148. 
found the size the same, two hundred and four feet. Can decay have decreased its size so much?

There are many fine Chestnuts on the banks of the river Tamer in Cornwall, and at Beckworth Castle, in Surrey. At Wimley, in Herts, a Chestnut in the year 1789 measured above fourteen yards round, at five feet from the ground: the trunk was hollow, but the vegetation still vigorous.

There was an old decayed tree in Gloucestershire, which contained within it a pretty wainscoted room, enlightened with windows, and furnished with seats.

The most remarkable tree of this kind in England is the celebrated one at Tortworth, the seat of Lord Ducie, in Gloucestershire: even in the year 1150, it was called the Great, or the Old Chestnut of Tortworth. It fixes the boundary of the manor, and is supposed to be upwards of a thousand years old. In 1790 it measured fifty-one feet in girth, at six feet from the ground; it divided at the crown into three limbs, one of which measured twentyeight feet and a half in girth, five feet above the crown.

" Lord Ducie," says Martyn, " has a beautiful painting of this ancient tree. I have, by the favour of his lordship an etching of it, made in $17 \% 2$, with this inscription : ' The east view of the ancient Chestnut-tree at Tortworth, in the county of Gloucester, which measures nineteen yards in circumference; and is mentioned by Sir Robert Atkins, in his history of that county, as a famous tree in KKing John's time; and by Mr. Evelyn, in his Sylva, to have been so remarkable for its magnitude in the reign of King Stephen, as then to be called the Great Chestnut of Tortworth; from which it may reasonably be supposed to have been standing before the Conquest.' When this etching was made, it was barely included 
within the garden wall, which bore hard upon it; but the present Lord Dacie removed the incumbrance, and at the same time applied fresh earth to the roots, which seems to have enlivened it. So late as the year 1788 it produced great quantities of fruit, which, though small, was sweet and well-flavoured.

Mr. Lysons, who has etched two views of this famous tree, contradicts most of the former accounts: he speaks of it in the year 1791 as measuring but forty-four feet four inches round at the thickest part; - says there is no authority but vague tradition to show at what period it became remarkable for its size, and affirms that it could never have been the boundary of the manor, for that it stands in the middle of it.

Sir Robert Atkins, too, who gives the circumference at nineteen yards, at an earlier period, thinks that originally there were several trees: and Mr. Marshall supposes that there are two trees joined together.

The largest Chestnut, therefore, of which we have any knowledge, and of which there have been no doubts as to individuality, is Il Castagno del Galea, before mentioned.

The leaves of the Chestnut remain on late in the autumn, when they are of a rich golden colour. Martyn remarks, that the nuts are a favourite food of the deer. It has been observed, that when many of these trees are planted together near a house, the odour, which to many persons is very offensive, is apt to be too powerful. Nothing will thrive under its shade.

The soundness of the timber has been much questioned by some; but it has proved, on some occasions, superior to the oak itself. It is particularly adapted 
for casks and water-pipes, not being liable to shrink after it is once seasoned.

\section{"_- Staves that nor shrink nor swell}

The cooper's close-wrought cask to chestnut owes."

Dodsley.

In Italy it is planted for stakes for vines; and with us for hop-poles. Some of the timber is finely variegated; and a colour being given to it by the use of alumwater, logwood, and Brazil-wood, it has been taken for mahogany.

Among the lower orders of the people in the Apennines, in Savoy, and some parts of the south of France, the nuts are a common article of food; not only boiled or roasted, but also made into flour, and formed into bread, cakes, and puddings. They are considered hard of digestion; yet there are instances in Italy of men living to the age of ninety or a hundred years, who have fed wholly on Chestnuts. They are eaten in Italy with orange or lemon juice and sugar, and are sold in the streets, roasted on a portable furnace; and were brought to fashionable tables in desserts, long before they were known as an article of luxury in England. These nuts are sometimes used for whitening linen, and for making starch.

Mr. Martyn deeply laments the neglect shown to this tree, and is earnest to encourage its cultivation. "Let us hope, however," says he, " to see it rear its head again as a timber-tree among us. A decree of the Council of Paris was published in May 1720, ordering that all the great roads should be planted with Chestnut, or other such fruit or forest trees as were suitable to the nature of the 
ground, at thirty feet distance from each other, and six feet from the top of the ditch."

Miller remarks, that considerable plantations of Chestnut have been made in the north of Great Britain. 'The Earl of Fife planted above sixty thousand trees in the county of Murray. In England, Mr. Windham's plantations in Norfolk, made in $1 \% \%$; upwards of 3,000 by Mr. J. Mace, at Ashford, in Kent; 8,000 by John Sneyd, Esq. at Belmont, in Staffordshire, planted about the year 1785; and six acres in Carlton Forest, by $\mathrm{Mr}$. J. Cowlishaw, planted with above 1,800 of these trees, with larch, ash, \&c.

Evelyn, speaking of the fruit, observes, that "We give that fruit to our swine in England which is among the delicacies of princes in other countries; and being of the large nut kind, is a lusty and masculine food for rustics at all times, and of better nourishment for husbandmen than cole and rusty bacon, yea or beans to boot, instead of which, they boil them in Italy with their bacon; and in Virgil's time they ate them with milk and cheese:

Sunt nobis mitia poma,

Castaneæ molles, et pressi copia lactis.'

Eclogue i.

' Chestnuts, and curds and cream shall be our fare.'

"Again: in the second pastoral, he says-

'Ipse ego cana legam tenerâ lanugine mala, Castaneasque nuces, mea quas Amaryllis amabat, Addam cerea pruna; et honos erit huic quoque pomo.'

"6 Rendered by Dryden-

' Myself will search our planted grounds at home,

For downy peaches and the glossy plum;

And thrash the chestnuts in the neighbouring grove,

Such as my Amaryllis used to love.' 
" Our swine do not perhaps often feed on Chestnuts now, though those of British growth are still at their mercy sometimes; but more Irequentily of deer. Ben Jonson speaks of

'A chestnut, whilk hath larded many a swine.'

"6 The best tables in France and Italy make them a service, eating them with salt, in wine or juice of lemon and sugar, being first roasted in the embers; and doubtless we might propagate their use among our common people, being a food so cheap and so lasting. In Italy they boil them in wine, and then smoke them a little; these they call anseri or geese, I know not why: those of Piedmont add fennel and nutmeg to their wine, but first they peel them. Others macerate them in rosewater. Bread of the flour is exceedingly nutritive; it is a robust food, and makes women well-complexioned, as I have read in a good author. They also make fritters of Chestnut flour, which they wet with rose-water, and sprinkle with grated parmigiano, and so fry them in fresh butter for a delicate. How we here use Chestnuts, in stewed meats and beatille pies, our French cooks teach us; and this is in truth their very best use, and very commendable."

Thunberg tells us, that at the Cape of Good Hope they are eaten by way of dessert, roasted with butter*.

Eaten raw, or in bread, they are not considered very easy of digestion. The best way to preserve them is in earthen vessels, in a cold place, or in dry sand.

The leaves are a good litter for cattle, and make good mattresses to lie on; but they make a crackling noise when a person turns upon them, whence they are called in

* 'Thunberg's Travels, vol. ii. p. 131. 
France lits de parliament. It is said that a decoction of the rind of this tree will dye hair of a beautiful golden colour.

The Chestnut being so beautiful a tree, would probably be much noticed by the Spanish poets, in whose country it grows so abundantly: it is but slightly mentioned in the poems of Garcilasso, lately produced in an English dress, by Mr. Wiffen :

"O fleet-foot Oreads of the hills! who go

Chasing through chestnut groves the hart and roe, Leave wounding animals, draw near and scan The last convulsions of a wounded man."

P. 217.

Dallaway, in his "Constantinople," speaks of its effect in landscape; in speaking of the view from Brusa, he says"This view is peculiar and beautiful, from the sudden eleration of the back-ground, the variety of situation in which the houses are clustered, and the rich verdure of the Chestnut groves, and enclosures of white mulberry for the silk-worms, which embellish the environs for a certain distance with most luxuriant regetation."

The author of a popular modern novel more than once adverts to the beautiful foliage of the Chestnut, especially as contrasted with trees of different hues:

"The delicate Chestnut woods, which last dare encounter the blasts of spring, whose tender leaves do not expand until they may become a shelter for the swallow, and which first hear the roice of the tyrant Libeccio, as he comes all conquering from the west, had already changed their hues, and shone yellow and red amidst the sea-green foliage of the olive, the darker but light boughs of the cork-trees, and the deep and heary masses of ilexes and pines." 
Chestnuts are mostly grafted, when cultivated for the sake of their fruit. There is a passage on this subject in Virgil, which has occasioned much dispute among the learned:-

"Et steriles platani malos gessere valentes;

Castaneæ fagus, ornusque incanuit albo Flore piri."

Georg. ii.

Some suppose this passage to signify that the beech has been grafted on the Chestnut: others considering it an absurdity to graft a tree upon one of superior value, read it differently, and believe it to mean, that the Chestnut was grafted on the beech. Upon which Martyn observes, that he sees no reason to reject the first, which is the common reading, since the fruit of the Chestnut-tree was very little esteemed in Virgil's time. Pliny wonders that nature should take such care of them as to defend them with a prickly husk, whereas the mast of the beech was reckoned a sweet nut; and men are said to have been sustained by it on a siege. The tree itself, too, was held in high veneration, and vessels made of it were used in the Roman sacrifices*.

In another passage the Roman poet alludes to its lofty growth. In speaking of the different manner in which trees are raised, he says-

"Pars autem posito surgunt de semine: ut altæ Castaneæ, nemorumque Jovi quæ maxima frondet Asculus-"

Georgic ii.

"Some are produced by seeds; as the lofty chestnuts, and the esculus, which has the largest leaves of all the groves of Jupiter."

Martyn's Translation. 
Roasted Chestnuts formerly accompanied the wassailbowl in the celebration of Christmas festivals.

"Remember us in cups full crowned, And let our city health go round, Quite through the young maids and the men, To the ninth number, if not ten; Until the fired chestnuts leap For joy to see the fruits ye reap From the plump chalice, and the cup That tempts till it be tossed up."

HERRICK.

Milton, writing on the death of his friend Deodati, says-

"In whom shall I confide? whose counsel find A balmy medicine for my troubled mind? Or whose discourse, with innocent delight Shall fill me now, and cheat the wintry nightWhile hisses on my hearth the pulpy pear, And blackening chestnuts start and crackle there, While storms abroad the dreary meaclows whelm, And the wind thunders through the neighbouring elm?" 


\section{CORNEL TREE.}

CORNUS.

CAPRIFOLIACEE.

TETRANDRIA MONOGXNIA.

Cornus, from cornu, a horn, on account of the horny hardness of the fruit : it is familiarly called Cornel-tree, and Dogwood-treeFrench, cornouiller ; Italian, corniolo, the fruit cornole.

The Cornus mascula, or male Cornel, familiarly called the Cornelian Cherry, in its wild state seldom exceeds five feet in stature; but when cultivated, will grow as high as eighteen or twenty feet. It has yellow blossoms, which appear before the leaves, growing in umbels. The leaves grow opposite in pairs ; the fruit is of the size and form of a small olive, and of a bright scarlet colour ; but the greater part of the flowers drop off without producing fruit.

In mild seasons, the blossoms will begin to open early in February ; they are not handsome, but as they appear early, are abundant, and produce a handsome fruit, the tree deserves a place in the shrubbery. Formerly it was cultivated for the use of its fruit, which was used for tarts, and kept in the form of a conserve in the apothecaries' shops. " "The preserved and pickled cherries," says Evelyn, "are most refreshing, an excellent condiment, and do also well in tarts." He likewise observes, that the wood is much commended for its durableness in wheel work, for pins and wedges, \&c. in which it exceeds the hardest iron; and relates what he very justly terms an odd notion of another author: "' Though Matthiolus 
affirms it, upon his own knowledge and experience, that one who has been bitten by a mad dog, if in a year after he handle the wood of this tree till it grow warm, relapses again into his former distemper.'

Such a tale may probably have originated in the notion that no one having been bitten by a mad dog could survive a year: just as nurses will tell children that they may catch a swallow if they can put a iittle salt upon its tail ; or as a sailor will jocosely observe of a desolate and barren shore, that it is death by law to fell a tree there, simply because there are none to fell.

This Cornel is a native of France, Switzerland, Carniola, Piedmont, Germany, Russia, \&c. Tournefort found both this and the female Cornel in the Levant. It was cultivated by Gerarde in 1596. He says, " It groweth not wild in England, but yet there be sundry trees of them growing in the gardens of such as love rare and dainty plaints: whereof I have a tree or two in my garden."

It was formerly called the Cornelia, or Long Cherrytree, but these names are now seldom used.

The Cornus sanguinea, or Common Dogwood, by some called the female. Cornel-tree, grows in the hedges, in most parts of Europe, especially where the soil is chalky. It flowers in June, and the berries ripen in August. This bears a variety of names in different parts of our country; as Hound's-tree, Hound's-berry tree, Dog-berry tree; Prickwood, from its use in making skewers; and Gaten, Gatten, or Gater tree. Chaucer speaks of the fruit by the name of Gaitres-berries.

It takes the specific name sunguinea from the vivid red colour of the young shoots. By old authors it is termed Virga sanguinea, Bloody-rod. The French 
call it Cornouiller Sauvage, or Sanguin; the Italians, Sanguine, or Sanguinello.

This Cornel is about the same height as the former species, when that grows wild: the blossoms are of a greenish white colour; the fruit dark purple.

The fruit of this tree is very similar to the buckthornberries sold in the markets, and has been sometimes purchased in mistake. It may be easily distinguished by opening one of the berries; that of the Cornel containing but one stone, the buckthorn-berry four. The latter, too, gives a green stain to paper, and the juice of the dogberry stains purple.

The wood, like that of the male Cornel, is noted for compactness, and is used for various rustic instruments. Cornel wood is considered the best for butchers' skewers. In some countries, an oil for lamps is obtained from the berries, by boiling them in water and pressing them.

The Cornus fiorida, or Great-flowered Dogwood, seldom exceeds eight feet in height. It does not produce fruit in this country, and blossoms but sparely; it is nevertheless very hardy, and well-clothed with large leaves.

There is a variety with rose-coloured blossoms, which was found in Virginia, of which it is said, that when the blossom first breaks forth, which is early in March, it is not so wide as a sixpence, but that it gradually increases to the size of a man's hand; being six weeks in coming to its full size. The berries are bright red, the size of large haws, and grow four or five together in a cluster: they are very bitter, and birds will not eat them but in times of dearth. The wood is white, close and hard like that of box.

This Cornel is a great ornament to the woods in America, flowering very early in the spring, and keeping the 
berries on (thanks to their bitterness!) all the winter. There are several other American species, among which, the handsomest is the Blue-berried, Cornus sericea, which was cultivated by Mr. Miller, in 1759. The shoots are of a fine red colour in the winter; and in summer, the large leaves, white on the under side, and the bunches of white flowers which terminate every branch, are very handsome. In the autumn, it is adorned with bunches of ripe blue berries.

There is a small species, commonly called the Herbaceous Dogwood, Cornus Suecica, by some the Dwarf Honeysuckle, which is a very elegant plant, not more than six inches high; the berries are eatable, and have a sweet watery taste, very agreeable to children. 'The Highlanders suppose them to create an appetite, whence the Erse name of Lus-a-chrasis, Plant of Gluttony.

It is comizon by the sides of rivulets in the Highlands of Scotland, in the north of England, and many of the northern parts of Europe, but is rery difficult to preserve in gardens.

Cornel wood was formerly used for javelins :

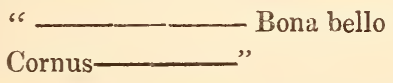

Georg. ii.

Says Virgil__" Cornel, good in war."

"Three henchmen were for every knight assigned, All in rich livery clad, and of a kind;

White velvet, but unshorn, for cloaks they wore, And each within his hand a truncheon bore;

The foremost held a helm of rare device, A prince's ransom would not pay the price ; The second bore the buckler of his knight; The third of cornel wood, a spear upright, Headed with piercing steel, and polished bright." DRYDEN's Flower and Leaf. 
A writer of our own time represents “ Faunus fast asleep ;

Upon whose outstretched arm, whose hand Loosely touched his cornel spear, His cheek was pillowed; flushed, and tanned With sports of sylvan cheer."

Amarinthus.

Homer mentions the Cornel as affording a coarse food, scattered to the companions of Ulysses, by Circe, after she had transformed them into hogs:-

"Meantime the goddess in dislain bestows The mast and acorn, (brutal food!) and strows The fruit of cornel, as they feast around."

ODYSSEY, book $\mathrm{x}$.

Virgil, also, speaks of the Cornel-berry : Achæmenides, one of the followers of Ulysses, whom the poet (in contradiction of Homer) supposes to have been left on the coast of Sicily, in the hurry of escape from the Cyclops, relating his adventures to Eneas and Anchises, says--

"Victum infelicem, baccas, lapidosaque corna Dant rami, et vulsis pascunt radicibus herbæ."

Æneirl. iii.

"Cornels, and savage berries of the wood, And roots and herbs, have been my meagre food."

Captain Franklin informs us that bears eat the Cornel berries, and fatten on them; whence they are named by the Crees Musqua muna, Bear-berries*.

* Journey to the Polar Shores. 


\section{CYPRESS TREE.}

\section{CUPRESSUS.}

French, cypres ; Italian, cipresso.

The Deciduous Cypress, Cupressus disticha, is a native of America, where it grows in watery places to a prodigious height and bulk. It is very hardy with respect to cold, but if planted in too dry a soil, will neither grow freely nor produce much fruit. John Tradescant, who first introduced this tree from Virginia, had one in his garden at South Lambeth, which is thirty feet high, and in good health and vigour, although it was not only neglected, but a number of nails had been driven into the trunk to fasten lines for drying linen.

Mr. Drummond, in his First Steps to Botany, lately published, gives this tree as an instance of a curious freak of nature. He quotes the following passage from Bartram's Travels :-

"It stands" (this tree, which in America is called the White Cedar) " in the first order of North American trees. Its majestic stature is surprising; we are struck with a kind of awe at beholding the stateliness of the trunk, lifting its cumbrous top towards the skies, and casting a wide shade upon the ground,--as a dark intervening cloud which for a time obscures the rays of the sun. The delicacy of its colour, and texture of its leaves, exceed every thing in vegetation. It generally grows in the water, or in low flat lands, near the banks of great 
rivers and lakes, that are covered great part of the year with two or three feet depth of water; and four or five feet higher up, is greatly enlarged by prodigious buttresses or pilasters, which in full grown trees project on every side to such a distance, that several men might easily hide themselves in the hollows between. Each pilaster terminates under ground in a very large strong serpentine root, which strikes off, and branches every way just under the surface of the earth." From the top of the buttresses, the tree, "6 as it were, takes another beginning, forming a grand straight column, eighty or ninety feet high; when it divides every way around into an extensive flat horizontal top like an umbrella, where the eagles have their secure nests, and cranes and storks their temporary resting places : and what adds to the magnificence of their appearance, is the streams of long moss that hang from the lofty limbs, and float in the winds. This is their majestic appearance when standing alone in large rice plantations, or thinly planted on the banks of great rivers."

The Arbor Vitæ-leaved Cypress (Cypressus thyoides), or as some call it, the White Cedar, is also an American, and grows to a considerable size, though with us it seldom exceeds fifteen feet; or if raised from cuttings, ten feet. Loureiro says, that in China or Cochin China, although a native of those places, it does not grow higher than eight feet. The branches are numerous, and stand two ways, naturally forming themselves into regular heads ; the leaves are evergreen, flat, sharp, very short, and imbricated: the fruit is blue, and not larger than that of the juniper.

This tree requires eighty years' growth from the seed, before it is fit for timber; and as the number of these 
trees has been much reduced, Miller observes, that posterity will probably feel the want of this useful tree in America. It makes good canoes, hoops, and other coopers' ware; it is much esteemed for shingles, and many houses are built with it.

The Cypress, the Evergreen Cypress, Cupressus sempervirens, is a native of the Levant, Candia, Rhodes, Malta, Apulia, some parts of the Russian empire, China, \&c.-It was cultivated in this country in 1551: Gerarde mentions it as growing "at Sion, a place near London, sometime a house of nuns ;" at Greenwich, and at Hampstead, in the garden of Mr. Waide, one of the clerks of his Majesty's privy council.

It is said there are still growing, in the gardens of a palace in Granada, several fine lofty Cypresses, that were large trees in the reign of Andeli the last Moorish king, three centuries ago. 'These trees are called Los Cypresses de la Regua Sultana, the Cypresses of the reigning Sultana, from that princess having been falsely accused of entertaining her lover Abencerrage under their shadow.

Pliny says, that in his time there were trees of this kind in Rome more ancient than Rome itself. There are still many fine Cypresses in modern Rome, though not of such high antiquity; and it has been observed, that no tree blends so well with stone buildings.

" This tree," says Miller, "6 is recommended by many learned authors for the improvement of the air, and as a specific for the lungs, as sending forth quantities of aromatic and balsamic scents; wherefore many of the ancient physicians of the Eastern countries used to send their patients who were troubled with weak lungs to the island of Candia, which at that time abounded with these trees." 
"However that may be," observes Martyn, "the Cypress is valuable on account of its wood, which is of a dusky or brownish red colour; has a sweet smell, and, on account of its hardness, is fit for a variety of purposes."

On account of its durability, Plato had the laws engraved on Cypress tablets, in preference to brass itself; and Pliny relates, that the statue of Jupiter in the Capitol, made of this wood in the year of Rome 661, was sound in his time.

"What the uses of this timber are," says Evelyn, " for chests and other utensils, harps, and divers other musical instruments (it being a sonorous wood, and therefore employed for organ-pipes, as heretofore for supporters of vines, poles and planks, resisting the worm, moth, and all putrefaction, to eternity), the Venetians sufficiently understood, who did every twentieth year, and oftener (the Romans every thirteenth), make a considerable revenue of it out of Candy: and certainly a very gainful commodity it was, when the fell of a $\mathrm{Cu}-$ pressetum (plantation of Cypresses) was heretofore reputed a good daughter's portion, and the plantation itself called Dos filice. But there was in Candy a vast wood of these trees belonging to the republic, by malice or accident (or perhaps by solar heat, as were many woods seventy-four years after, even here in England) set on fire : which beginning anno 1400, continued burning for seven years before it could be extinguished, being fed for so long a space by the unctuous nature of the timber, of which there were to be seen at Venice planks of above four feet in breadth. And formerly the valves of St. Peter's Church were formed of this material, which lasted from the great Constantine to Pope Eugenius the Fourth's 
time (eleven hundred years), and then were found as fresh and entire as if they had been new. But this pope would needs change them for gates of brass, which were cast by the famous Antonio Philarete; not, in my opinion, so venerable as those of Cypress. It was in coffins of this material that (as Thucydides tells us) the Athenians used to bury their heroes; and the mummy-chests brought with those condited bodies out of Egypt are made of this material, which it is probable may have lain in those dry and sandy cryptæe many thousand years."

The bridge built by Semiramis over the Euphrates was of Cypress-wood, and it is still used in Candia and Malta for building.

Evelyn remarks, that the very chips are frequently used to flavour rich wines; that the cones or chips, burned, will destroy or drive away moths, gnats, and flies; and that it yields a gum not much inferior to mastick. He desires his readers not to " despair of the resurrection of a Cypress subverted by the wind, for some have redressed themselves, and one (as Tiphilinus mentions) rose the very next day; which happening about the reign of the Emperor Vespasian, was esteemed an happy omen."

"The mountain-cypress thus, that firmly stood

From age to age, the empress of the wood,

By some strong whirlwind's sudden blast declined,

Bends arching down, and nods before the wind:

The deep roots tremble till the gust blows o'er,

And then she rises stately as before."

Harte's Statius.

This author observes, that the durability of this timber has been celebrated by Vitruvius and Martial, and that it is considered no less beautiful than durable, 
" especially the roots of the wilder sort: incomparable for its crisped undulations."

The wild Cypress here mentioned was used among the great in Rome for beds and tables: it was esteemed for the spots and figures in the wood, from which the tables were called Mensa Tigrina et Pantherince. With them it bore the name of Citron; and is mentioned by that name in Lucan's Pharsalia:

" On every side proud palaces arise, And lavish gold each common use supplies. Their father's frugal tables stand abhorred, And Asia now and Afric are explored, For high-priced dainties, and the citron board."

Rowe's Lucan, book i.

In old times the Cypress was held sacred to Pluto and Proserpine; and was used at funerals, especially of persons of fashion:

"Et non plebeios luctus testata cupressus-"

Book iii.

says Lucan;-which Rowe thus translates:

"The eypress by the noble mourner worn."

It was either placed before the house, or in the restibule, that no person about to perform any sacred rites might enter a place polluted with a dead body. It has been said that the Cypress was selected on these melancholy occasions, because this tree, being once cut down, never springs up again. Evelyn justly remarks, that in this view it would be an improper emblem in a Christian country. "The use of evergreens," says he, " is yet not uncommon among us; but they are supposed to be significant of immortality, at the same time that their 
balsamic scent guards the attendants against the infection to be apprehended from a putrid body."

And it is worthy of notice, that most of the trees and plants more particularly used on these occasions are fragrant; as the tree in question, the wood of which has a sweet and powerful scent; rosemary, basil, vervain, asphodel, \&c.-The yew has a powerful scent rather than a sweet one.

The Cypress is often praised for its sweet odour: " And a brook

Flowing from out a little gravelly nook Keeps green the laurel and the myrtle trees And odorous cypresses."

Hunt, from Theocritus.

Homer speaks of its fragrance in his description of the cave of Calypso, in the fifth book of the Odyssey.

Virgil repeatedly introduces the Cypress at the funeral rites of his heroes; as at that of Misenus :

"Ingentem struxere pyram : cui frondibus atris Intexunt latera, et ferales ante cupressos

Constituunt, decorantque super fulgentibus armis."

ENEID, book vi.

"First from the groun a lofty pile they rear Of pitch-trees, oaks, and pines, and unctuous fir ; The fabrick's front with cypress-twigs they strew, And stick the sides with boughs of baleful yew. The topmost part his glittering arms adorn-"

DRYDEN's Translation.

Tasso uses it on a similar occasion :

"Sorse a pari col sole, ed egli stessu Seguir la pompa funeral poi volle

A Dudon d'odorifero cipresso

Composto hanno un sepolcro a piè d'un colle 
Non lunge agli steccati, e sovra ad esso Un’ altissima palma i rami estolle.

Or qui fu posto; e i sacerdoti intanto Quiete all' alma gli pregar col canto."

Canto iii. st. 72.

Fairfax's translation of this stanza is rather free:

"Up with the lark the sorrowing Duke arose,

A mourner-chief at Dudon's burial:

Of cypress sad a pile his friends compose

Under a hill o'ergrown with cedars tall:

Beside the hearse a fruitful palm-tree grows

(Ennobled since by this great funeral),

Where Dudon's corpse they softly laid in ground.

The priests sang hymns, the soldiers wept around."

Statius makes the same use of it $*$

In the Italian Arcadia, the shepherd says to his friend-

"Voi userete in me il pietoso ufficio, E fra cipressi mi farete un tumulo."

You shall perform for me the last pious office, and shall make me a tomb among cypresses.

Spenser describes it as emblematical of death :

"And the sweet cypress, sign of deadly bale."

Virgil's Gnat.

Again, in his lamentation for the death of Sir Philip Sidney :

"Instead of girlond, wear sad cypress now, And bitter elder, broken from the bough."

It is doubtless this tree to which the poet refers in another passage in the same poem :

"The tree that coffins doth adorn,

With stately height threatening the sky."

* See the Sixth Book, translated by Harte. 
He places it in the garden of Proserpine:

"There mournful cypress grew in greatest store, And trees of bitter gall, and heben sad."

Fairie Queene, book ii.

The Earl of Suffolk, in calling down curses on his enemies, would have-

"Their sweetest shade a grove of cypress-trees."

King Henry the Sixth, Part II.

It is designated by Tasso as

"The funeral cypress."

Sir Walter Scott's song is well known:

"O lady, twine no wreath for me,

Or twine it of the cypress-tree."

Melancholy and death seem to be associated with the Cypress-tree in all countries; Thunberg says-

"The churches of all the different religious sects are in general built upon the most eligible spots, both in the villages and in the towns; the roads leading to them likewise are frequently adorned with alleys of cypress-trees*:"

Dallaway, in his "Constantinople," observes, that the entrance into Smyrna is through spacious cemeteries and luxuriant cypress-groves.

But here the Roman custom seems to be reversed; for the author remarks that

_ the humbler graves are marked by cypresses at the head and feet, from which custom extensive groves have grown, and are seen in every stage of vegetation."

The tombs of persons of distinction are marked by ornamented stones, and flowers of the choicest kinds. 
Dallaway represents the Seraglio of Constantinople as " encircled with embattled walls, with its domes and kiosques clustered in splendid confusion, and intermixed with gigantic Cypresses, rising in the sea from an elevation which nature seems to have intended for the seat of dominion over the whole world."

Lord Byron describes

"The cypress saddening by the sacred mosque."

Corsair.

Again, he says, speaking of the Simoom:

"Beneath whose widely wasting breath

The very cypress droops to death;

Dark tree! still sad when others' grief is fled,

The only constant mourner o'er the dead."

Giaour.

Browne, it seems, was of a different opinion :

"'Tis not a cypresse bough, a count'nance sad, A mourning garment, wailing elegie,

A standing herse in sable vesture clad,

A toombe built to his name's eternitie,

Although the shepherds all should strive

By yearly obsequies,

And vow to keep thy fame alive

In spight of destinies;

That can suppresse my griefe .

All these and more may be,

Yet all in vain to recompence

My greatest loss of thee.

Cypresse may fade, the countenarice be changed,

$\Lambda$ garment rot, an elegie forgotten,

A herse 'mongst irreligious rites be ranged,

$A$ toombe pluakt down, or els through age be rotte11: 
All things th' unpartial hand of fate

Can rase out with a thought:

These have a several fixed date,

Which ended, turne to nought.

Yet shall my truest cause

Of sorrow firmly stay,

When these effects the wings of time

Shall fanne and sweepe away."

W. Browne's Shepherd's Pipe.

Montgomery would rather associate more pleasing ideas with the memory of a departed friend :

"To some warm heart the poorest dust was dear,

From some kind eye the meanest claimed a tear ;

And oft' the living, by affection led,

Were wont to walk in spirit with their dead, Where no dark cypress cast a doleful gloom, No blighting yew shed poison o'er the tomb, But, white and red with intermingling flowers :

Green myrtle fenced it, and beyond their bound, Ran the clear rill with ever murmuring sound. 'Twas not a scene for grief to nourish care,

It breathed of hope, and moved the heart to prayer."

World before the Flood.

The origin of the Cypress-tree, and the reason of its association with ideas of gloom and death, is mentioned by Ovid:

"Dear to the god, who awes, yet charms the throng, Who strings the bow for war, the harp for song, Thither, a youth of yore, but now a shade, small by degrees, the mournful cypress strayed.

A giant-stag once coursed Carthœa's glades, Admired, nay worshipped, by the sylvan maids : Antlers of gold rose glittering on his head, Round his sleek throat a chain of jewels spread Fell on his shoulder: fixed by leathern ties, $\Lambda$ ball of silver played between his eyes, 
And brazen drops, suspended from the ear, Beamed on the hollow temples of the deer.

His timorous nature cast aside, he ran Oft, fond and fearless, to the haunts of man; And proffered oft, with not a doubt to check, E'en to a stranger's patting hand, his neck. Beloved of all, he roamed: but whose soft care, Fond Cyparissus, could with thine compare? Loveliest of Cea's sons, 'twas thine to lead The stag, light-bounding, to some greener mead, Or clearer spring; delighted, to adorn With wreaths of blooming flowers each polished horn; Or mount his back, and guide, with purple rein Now here, now there, thy playmate o'er the plain.

It chanced that Sol in Cancer's hot embrace, Blazed in meridian fervor o'er the place:

Down lay the stag beneath a cooling shade, Supine and panting on the grassy glade.

Thither young Cyparissus strays; his spear Is hurled, it flies, it strikes the unknown deer; But when he views his darling weltering there, How longs the boy the death he dealt to share The radiant god thus strives to yield relief :

' The loss is trivial, trivial be the grief;

For what thou hast done thy tears have well atoned ; Then groan no more :' yet still the stripling groaned; And prayed of Heaven, his last request, to doom His life to waste in everlasting gloom.

When, lost in tears, the blood his veins forsakes; His every limb a grassy hue partakes;

His flowing tresses, stiff and bushy grown, Point to the stars, and taper to a cone. Now Phœbus thus: 'Ah! youth, beloved in vain, Long shall thy boughs the gloom I feel retain: Henceforth, when mourners grieve, their grief to share, Emblem of woe, the cypress shall be there."

Dr. ORGER's Translation. 
Cowley refers to this poetical origin of the tree, in his lines on the death of Mrs. Hervey :

"Instead of bays, crown with sad cypress me,

Cypress which tombs doth beautify:

Not Phœbus grieved so much as I,

For him who first was made that mournful tree."

\section{Sannazaro alludes to it also :}

" Ma fra tutti nel mezzo, presso un chiaro fonte, sorge" verso il cielo un dritto cipresso, veracissimo imitatore delle alte mete, nel quale non che Ciparisso, ma (se dir conviensi) esso Apollo non si sdegnarebbe essere trasfigurato."

Arcadia.

But in the midst of all, near a clear fountain, rose towards heaven a straight cypress, lofty, pyramidal ; to such a tree, not Cyparissus only, but if we so may speak, Apollo's self, need not disdain to be transformed.

Tasso describes the form of its growth :

"Alfine un largo spazio in forma scorge

D'anfiteatro, e non è pianta in esso

Salvo che nel suo mezzo altero sorge

Quasi eccelsa piramide, un cipresso."

At length a spacious valley he descried,

In which grew nothing but a cypress-tree,

That, in the centre, rose with stately pride,

Of form pyramidal :-

Mr. Shelley gives a grand and striking picture of the Cypress-tree :

"Thence to a lonely dwelling, where the shore

Is shadowed with steep rocks, and cypresses

Cleave with their dark green cones the silent skies,

And with their shadows the clear depths below." 
Dallaway, speaking of the Cypress-trees about Constantinople, observes, that no accurate judgment of them can be formed, from "the shrubs called Cypresses which the climate of England allows us to rear." $\mathrm{He}$ says, they are seldom seen there in the forests, but that in the cemeteries and the environs of palaces it is common to see them six feet in circumference, "with a height proportioned to a pyramidal form.".

This does not, however, give a very correct idea of the height, since it is not the stem of the tree, but the outline of the branches, which takes a pyramidal form. W. Browne expresses it very curiously :

"Cypresses that like piramides runne topping, And hurt the least of any by their dropping."

Homer refers to its use in building :

"Next came Ulysses lowly at the door,

A figure miserable, old, and poor,

In squalid vests, with many a gaping rent, Propt on a staff, and trembling as he went. Then resting on the threshold of the gate, Against a cypress-pillar leaned his weight, (Smoothed by the workmen to a polished plane) The thoughtful son beheld, and called his swain."

Pope's Translation of the Odyssey, book xvii.

As aiso does Virgil; speaking of the barren woods on Mount Caucasus, he says, even these afford useful timber; the pine for ships, cedars and cypresses for houses:

"Navigiis pinos, domibus cedrumque cupressosque."

Georgic ii. 
The Cypress lives to a great age, and some have grown to an enormous bulk. Evelyn speaks of one that grew in Persia, of which the stem was as large as five men could encompass: it was supposed to be two thousand five hundred years old. 


\section{ELDER.}

\section{S A M BU CUS.}

French, sureau ; Italian, sambuco.

TuE common Elder, Sambucus nigra, is a bushy tree, growing to a height of about sixteen feet, much branched, and covered with a smooth grey bark when young, which afterwards becomes rough on the trunk and older branches. The flowers are of a mellow creamy white, with a faint sweet smell, especially when dried; the berries are globular, dark purple, mawkishly sweet ; their juice watery and red. The wood is hard and tough, and will take nearly as good a polish as box.

This tree is a native of Britain, and many other parts of Europe, of Africa, of Japan, \&c. In this country it grows abundantly in damp hedges and woods ; flowering in May and June.

The whole plant has a narcotic smell, and it is not prudent to sleep under its shade, notwithstanding Thomson's recommendation :

" When the sun

Shakes from his noon-day throne the scattering clourds, $\mathbb{E}^{\prime}$ en shooting listless languor through the deeps, Then seek the bank where flowering elders crowd;

Where, scattered wild, the lily of the vale

Its balmy essence breathes, where cowslips hang

The dewy head, where purple violtis lurk,

With all the iowly children of the shade." 
The younger branches contain a great quantity of pith, which, being very light, is made into balls for electrical experiments.

It has been said, that insects in general have so great a dislike to the Elder, that if turnips, cabbages, fruit-trees, ol corn, be whipped with branches of it, or if a gate stuck full of them be drawn over the crops, no insects will attack them; and that an infusion of the leaves is useful to sprinkle over such beds as the gardener may wish to preserve from small caterpillars. It is thought even to be sufficiently powerful to drive away the mole, if laid in his subterranean domains; yet the Elder has its own aphis, and, according to Evelyn, a very troublesome one.

The flowers are considered poisonous to turkeys, and the berries to poultry in general ; cattle mostly refuse the Elder, sheep are fond of it, and it is supposed healthful for them.

The wine made by housewives from the elder-berry is well known, and by many persons esteemed, though some think it nauseous ; the juice is also used to colour raisin and other wines, and to give a flavour to vinegar. Elder-flower water is frequently used in this country as a cooling lotion for the skin. The Russians and the missionaries at the Cape use an infusion of these flowers as a sudorific in colds*.

"This tree," says Miller, "is as it were a whole magazine of physic to rustic practitioners; nor is it quite neglected by more regular ones." Evelyn says, if the medicinal properties of the Elder, " leaves, bark and berries, were thoroughly known, I cannot tell what our countryman could ail, for which he might not fetch a

* Latrobe's South Africa, p. 388. 
remedy from every hedge, either for sickness or wound. Yet," continues he, "I do not by any means commend the scent of it, which is noxious to the air ; and therefore, though I do not undertake that all things that sweeten the air are salubrious, nor all ill savours pernicious, yet, as not for its beauty, so neither for its smell, would I plant Elder near my habitation; since we learn from Biesius, that a certain house in Spain, being seated among many Elder-trees, diseased and killed almost all the inhabitants; which, when at last they were grubbed up, became a very wholesome and healthy place."

The scent is said to occasion violent head-aches to those who remain long near them.

There is a variety of the Elder, with white berries, and another of which the ripe berries are red; of this last the leaves are eaten by the red-deer, and the berries by partridges, moor-game, \&c. It is a native of Germany, Switzerland, Italy, and Siberia, and was cultivated here by Gerarde in 1596.

The Canadian Elder, Sambucus Canadensis, is smaller than the common species; the berries also are smaller, and less juicy. This flowers from June to August; it was cultivated here by Miller in 1768 .

According to Mr. Hall, the Elder is called by the lower orders in Scotland the Arn-tree: "It is a fact," says he, "that from the bark of the Elder, or Arn-tree, as the common people call it, the juice of ragweed, and a few other productions of the country, the women in the interior, even at this day, as has been done in all ages, produce in their tartans, \&c. as various and vivid colours as the dyers in England can do with their foreign drugs."

Sannazaro celebrates the scent of the Elder-flowers; he speaks of the eve preceding the festival of Pales: 
"Non ostante che i fronzuti Sambuchi, coverti di fiori odoriferi l'ampia strada quasi tutta occupassero, il lume della luna era si chiaro, che non altrimenti che se giorno stato fosse ne mostrava il camino."

Arcadia.

Notwithstanding the branching Elders, covered with odoriferous flowers, spread their shade over the whole way, the light of the moon was so clear, that we saw our road as though it had been day.

The Elder is sometimes coupled with the cypress, and other trees considered as emblematical of death or sorrow :

"The water-nymphs, that wont with her to sing and dance,

And for her girlond olive-branches bear,

Now baleful boughs of cypress done advance:

The muses that were wont green bays to wear,

Now bringen bitter elder branches sere:

The fatal sisters eke repent

Her vital thread so soon was spent.

O heavy herse!

Mourn now, my muse, now mourn with heavy cheer :

O careful verse!"

SPENSER.

The musical pipe called by the Italians Sampogna was formerly made of Elder-wood; and it is supposed that the name is corrupted from Sambuco.

The Elder-tree is very common in the hedge-rows, and by brook-sides, even in the neighbourhood of London, adorning and enlivening them with their beautiful white blossom. Happily for the housewives who make wine of the berries, the temptation to gather, offered by the beauty of the flowers, is counteracted by their unpleasant odour; and they are left to perfect their fruit. 
The elder there

Its purple berries o'er the water bent, Heavily hanging."

\section{Southey.}

The ripe berries are sometimes plucked and eaten by children, but they have a sickly flavour, which pretty generally ensures their safety.

That most imaginative of all personages, tradition, reports that Judas hung himself upon an Elder-tree*.

* See Every Man out of his Humour.-Ben Jonson's Works, vol, ii. p. 148. 


\title{
ELM TREE.
}

\author{
ULMUS.
}

ULMACE IE.

PENTANDRIA DIGYNIA.

French, orme ; Italian, ulmo, olmo.

The Common Elm, Ulmus campestris, is a native of Europe and Barbary ; it is generally supposed to be indigenous of England, though Evelyn and some others doubt whether this really be the case; all agree, however, that if not a native, it has been naturalized here even from the time of the Saxons. Dr. Hunter is convinced that it is a native of this country: "of which," he says, "there can be no stronger proof, than that there are nearly forty places in this kingdom which have their names from it; most of which are mentioned in Domesday-book. Chaucer lived at New Elm, in Oxfordshire; Dryden at Nine Elms, near Lambeth : there is also Barn-Elms, \&c."

The bark of the young trees, or of the younger branches of old trees, is smooth, and very tough, and may be stripped off from the wood to a great length without breaking. As the trees grow old and large, the bark of the body cleaves or rends apart, which makes the surface rough.

The blossoms, which are of a pale red colour, appear before the leaves, about the end of March, growing in clusters on the twigs: they are succeeded by flat seeds, of which the greater part fall away before, or immediately after, the leaves spring forth; but a few will hang on nearly all the summer. The leaves are dark green, about two inches broad, and three long; rough on 
both sides, indented about the edges; having a nerve in the middle, and many smaller nerves growing from it.

It is a quick growing tree: " in little more than forty years," says Evelyn, "it will yield a load of timber." Martyn mentions " an Elm planted by Henry the Fourth of France, which was still standing in the Luxembourg Gardens in Paris when the Revolution broke out: but whether it has survived that event," continues he, "I am unable to say. This great monarch's famous contemporary, queen Elizabeth, is said to have planted an Elm with her own hand at Chelsea, where her father had a palace, in which she was brought up when an infant. It went always by her name, and I remember it a stately flourishing tree, except that the top was decayed. It stood at the upper end of Church-lane, near where the turnpike now is, and was a boundary of the parish on the north side. It was felled, to the great regret of the neighbourhood, on the 11th of November 1745, and sold for a guinea, by Sir Hans Sloane, Bart. lord of the manor. It was thirteen feet in circumference at the bottom, and six feet six inches at the height of forty-four feet: the height was an hundred and ten, of which fifteen feet at the top were decayed ; the tree having suffered in the hard frost in 1739-40*." Another Elm was planted in its place, which bids fair, if it does not meet with any accident, to rival its predecessor.

In the middle of the last century an Elm was standing at Charlton, in Kent, about which Horn Fair was kept ; the boughs spread to a distance of eight yards on every side, although the trunk was not more than a foot in diameter: this is now cut down, and a young tree planted

* Sec Martyn's edition of Miller's Dictionary. 
in its stead. Some Elms at Fulham were planted in the time of Edward the Sixth, and one at Richmond is said to have been planted by a courtier of King Henry the Seventh, when he kept his court there: this last is still in its prime.

One of Sir Francis Bacon's trees in Gray's-Inn Walks, planted in 1600, was felled, upon a suspected decay, in 1720 or 1726 , and was then above twelve feet round.

Mr. Coxe, in his account of Monmouthshire, mentions an ancient Elm at Raglan Castle, twenty-eight feet five inches in circumference near the root. Some of the finest trees of the kind are said to grow in the Vale of Gloucester; and the finest Elm in the vale stands in the road between Cheltenham and Tewksbury, very near to the Boddington Oak. It is known by the name of Piffe's Elm, and the toll-gate is called Piffe's Elm Pike. The smallest girth of this tree, which is about five feet from the ground, was in 1783 exactly sixteen feet. At ten feet it threw out large branches, which were formerly lopped, but were then furnished with branches seventy or eighty feet high, and of proportionable extent*.

It is to be hoped that something will be done, before it be too late, to prevent the threatened destruction of the fine Elm-trees in St. James's Park †.

* See Martyn's edition of Miller's Dictionary.

+ An examination having lately been made into the state of the Elm-trees in St. James's and Hyde Parks, by desire of the Ranger, Lord Sidney, they were discovered by Mr. Macleay 'who made the examination) to be infested by a species of beetle which had already done considerable mischief, and threatened their entire destruction.

"The Elm-trees in both the parks," says Mr. Macleay, "and particularly in St. James's, are rapidly disappearing; and unless decisive measures be soon taken to resist the progress of the contagion, we must not only expect every tree of this species to be 
Evelyn commends Elm timber for a variety of purposes, on account of its toughness and long durance in

destroyed in the parks, but may have to regret the dissemination of the evil throughout the vicinity of London.

"In St. James's Park, which has more particularly been subject to my examination, there are several species of beetles to be found attacking the Elms. 'That species, however, which occasions all the havoc we have now to lament in the Mall and Bird Cage Walk is the Hylesinus destructor of Fabricius, or Scolytus destructor of Latreille; an insect of which the history is briefiy as follows :

"A small beetle, with its head rather covered with hair, having a polished black thorax, and brown wing-cases, may be seen in numbers running over the trunks of the Elms, from the end of March to the first days of July; but principally about the end of May, or commencement of June. It may then be seen entering into holes, with which the bark is perforated as though with a gimblet. It insinuates itself into these holes, or into the crevices of the bark, for the purpose of depositing its eggs. On stripping off a piece of the loose bark, we may easily, at any season, understand how the barking of trees is effected by these minute animals, for the surface of the wood thus exposed presents to the view innumerable impressions, which may be compared to impressions or cast's of large and broad scolopendræ.

"The middle or body of this singular impression marks the path of the perfect female insect, while employed in laying her eggs, which is to her, as to most winged insects, the forerunner of death. From this tubular path, however, in which she deposits her eggs, the larvæ, which are hatched from these eggs, in the shape of little white apod worms, proceed nearly at right angles, eating their way in parallel smaller tubes, which, lying close to each other, effectually serve to separate the bark from the tree. The larvæ remain feeding in the tree, generally between the bark and the wood, throughout the winter season. About the commencement of spring they assume the pupa or nymph state, and, before the end of this season, the bark of an infected tree begins to appear as if all its crevices were full of a fine saw-dust. The last change of the insect takes place; and, being now winged, it tries to arrive at the ex- 
either extreme of wet or dry. " It is proper, too," he says, " by reason of the tenor of the grain, for all those curious works of fruitages, foliages, shields, statues, and most of the ornaments appertaining to the orders of architecture."

It is frequently substituted for oak in carpenters' work of all kinds, and is liberally used in house-building. In Norway, in times of scarcity, the bark dried and powdered has been mixed with meal for bread.

The dried leaves are a good winter fodder for cattle. In some parts of Herefordshire they are gathered in sacks for that purpose. Virgil praises the tree for the quantity of leaves it yields :

"Fœcundæ frondibus ulmi."

"Fruitful in leaves, the elm."

The Elm is considered injurious, and sometimes even fatal to bees; so that where Elms grow in great numbers, they do not thrive. Dr. Hunter, in his notes to Evelyn, here takes occasion to quote a passage from Virgil descriptive of the malady so fatal to bees, supposed to be occasioned by feeding on the Elm. It may not be amiss to follow so good an example:

ternal air, for the purpose of propagating its species, and laying its eggs in other trees. Each hole, which now appears as if made with a gimblet, marks the exit of a perfect insect. In the first instance, the voracity of the larvæ, and, in the second, the endeavours of the perfect insects to liberate themselves from the wood, particularly when such attempts are made by almost infinite numbers, soon occasion the bark to fall in large pieces. The consequence is, that the new leaves only make their appearance to wither, and the tree perishes."

See W. S. Macleay, Esq. on the State of the Elm-trees in St. James's and Hyde Parks, in the Edinburgh Philosophical Journal for July 1824 . 
"But when, as human ills descend to bees, The pining nation labours with disease ; Changed is their glittering hue to ghastly pale, Roughness and leanness o'er their limbs prevail; Forth the dead citizens with grief are borne, In solemn state-the sad attendants mourn : Clung by the feet they hang the live-long day Around the door, or in their chambers stay; Hunger, and cold, and grief their toils delay. "Tis then in hoarser tones their hums resound Like hollow winds, the rustling forest round ; Or billows breaking on a distant shore, Or flames in furnaces that inly roar. Galbanean odours here I shall advise; And through a reed to pour the sweet supplies Of golden honey, to invite the taste Of the sick nation to their known repast : Bruised galls, dried roses, thyme, and centaury join, And raisins, ripened on the Psithian vine. Besides, in meads the plant amellus grows, And from one root thick stalks profusely throws, Which easily the wandering simpler knows."

WARTon's Translation.

Martyn observes, that the twigs of the Elm were formerly used as instruments of castigation; for that Plautus speaks of a rogue who had been chastised so often, that he had wasted all the Elms in the country in rods and cudgels.

"The EIm," says Gilpin, " naturally grows upright, and where it meets with a soil it loves, rises higher than the generality of trees; and after it has assumed the dignity and hoary roughness of age, few of its forest brethren, though properly speaking it is not a forester, excel it in grandeur and beauty. The character of the Elm, in its skeleton, partakes much of the oak; so much, 
that when it is rough and old, it may easily, at a little distance, be mistaken for the oak. In full foliage its character is better marked; and no tree is better adapted to receive grand masses of light ; nor is its foliage, shadowing as it is, of the heavy kind: its leaves are small, and this gives it a natural lightness; it commonly hangs loosely, and is in general very picturesque."

There is a variety of the common Elm, called the Narrow-leaved Elm, which is altogether cf smaller growth : this is called in the nurseries the English Elm, an appellation of which Miller and some others dispute the propriety.

The Cork-barked Elm, Ulmus suberosa, or, as it is commonly called, the Dutch Elm, because introduced here from Holland, is chiefly remarkable for its fungous rough bark, and its quick growth. The wood is of very inferior quality.

The Broad-leaved Elm, Ulmus montana, is also called the Wych Elm, or Wych Hazel. The trunk soon divides into long wide-spreading branches; and when at full growth, is not above a third of the height of the common Elm. It blossoms before it is thirty feet high, whereas the common Elm seldom flowers till it has attained a much greater height and age. The bark is so tough, that the boughs may be peeled from one end to the other, without its breaking: and this is often made into ropes. The leaves are twice the size of those of the common Elm, and resemble those of the hazel. This tree grows plentifully in most parts of Hampshire, where it is commonly called Witch Hazel. It will prosper in a moist or a dry soil, on high hills, or in low valleys.

The wood of this tree was used for long-bows when 
they were in fashion, and it is recommended for that purpose in the English statutes.

It is found in shady lands, and the outskirts of woods in most parts of England, and is considered indigenous. Martyn observes, that old writers always spell the name Witch, as Goodyer, Ray, Evelyn, \&c., but that the prevailing mode now seems to be Wych; and that the tree is more commonly called by that name, without the adjunct of Elm or Hazel.

Cultivation and situation make many slight differences in the Elm, which have hastily been taken for specific, but afterwards proved mere varieties, - too uncertain, or too unimportant, in many instances, to deserve attention.

The American Elm, Ulmus Americana, was cultivated in England by James Gordon, Esq. in 1752. Of this American Elm, specifically so called, there are three varieties-the Red, the White, and the Weeping Elm: the two former take their name from the colour of their branches; the latter from their pendent growth. The Red Elm is said to grow very fast in this country. Kalm says, that boats are made of the bark of the White Elm; the method of making which he particularly describes.

The Hornbeam-leaved Elm, Ulmus nemoralis, also a native of North America, was cultivated here by J. Gordon, Esq. in 1760.

The Dwarf Elm, Clmus pumila, which in sandy lands is very small, in southern Russia contends in stature with the oak. The leaves are used in some parts of Russia as a succedaneum for tea.

Chatterton compares a dying warrior to an Elm torn by a storm :- 
"Distort with peyne he laie upon the borne,

Lyke sturdie elms by stormes in uncothe wrythynges torne."

Battle of Hastings.

In another passage of the same poem, speaking of a lady's shape, he says it is

"Tapre as elmes that Goodricke's abbie shrove."

Leigh Hunt, whose poetry always dwells upon the more cheerful side of things, compares this tree to a warrior before battle :

"As I thought thus, a neighbouring wood of elms Was moved, and stirred and whispered loftily; Much like a pomp of warriors with plumed helms, When some great general whom they long to see Is heard behind them, coming in swift dignity."

Nymphs, part ii.

The Elm was in high esteem among the ancients : they preferred it to every other as a prop for vines, and this connexion is continually noticed by the poets. Spenser calls it the "Vine-prop Elm." Harte, in the translation of Statius, the "Nuptial Elm." Fairfax, in his translation from Tasso, says-

"The married elm fell with his fruitful vine."

"The lofty elm, with creeping vines o'erspread."

Orger's Ovid.

Milton, describing the innocent occupations of Adam and Eve in Paradise, says-

"___ They led the vine

To wed her elm; she, spoused, about him twines

Her marriageable arms, and with her brings

Her dower, the adopted clusters, to adorn

His barren leaves." 
"Behold at length where yonder clustering vine Her amorous arms around the elm extends."

Andreini's Adam.

"Sometimes the beauteous, marriageable vine He to the lusty bridegroom elm does join,"

says Cowley; although Horace, in the original ode, of which this is a translation, speaks of the poplar instead of the Elm :

" Ergo aut adulta vitium propagine Altas maritat populos."

Ode ii. lib. v.

The amorous vine

Did with the fair and straight-limbed elm entwine."

F. BEAUMONT.

The following passage is from Harris's Lines on the Death and Works of Fletcher :

" Singly we now consult ourselves and fame, Ambitious to twist ours with thy great name. Hence we thus bold to praise : for as a vine With subtle wreath, and close embrace, doth twine A friendly elm, by whose tall trunk it shoots, And gathers growth and moisture from its roots, About its arms the thankful clusters cling Like bracelets, and with purple ammelling The blue-cheeked grape, stuck in its verdant hair Hangs like rich jewels in a beauteous ear. So grow our praises by thy wit; we do Borrow support and strength, and lend but show *." “ The gentle myrtle

Is not engraft upon an olive's stock; Yet nature hath between them locked a secret Of sympathy, that, being planted near, 
They will, both in their branches and their roots, Einbrace each other ; twines of ivy round * The well-grown oak; the vine doth court the elm; Yet these are different plants."

Ford's Lover's Melancholy.

"Come olmo, a cui la pampinosa pianta

Cupida s'avviticchi e si marite,

Se ferro il tronca, e turbine lo schianta,

Trae seco a terra la compagna vite ;

Ed egli stesso il verde, onde s'ammanta, Le sfronda, e pesta l'uve sue gradite.

Par che sen dolga, e più che 'l proprio fato,

Di lei gl' incresca che gli muore allato."

TAsso, canto $\mathrm{xx}$.

"As the high elm, whom his dear vine hath twined Fast in her hundrel arms, and holds embraced, Bears down to earth his spouse and darling kind, If storm or cruel steel the tree down cast, And her full grapes to nought doth bruise and grind, Spoils his own leaves, faints, withers, dies at last, And seems to mourn and die, not for his own, But for her loss, with him that lies o'erthrown." Fairfax's Translation.

"The olive, that in wainscot never cleaves;

The amorous vine that in the elm still weaves."

W. BROWNE.

Instances of this union are without end: the ivy too is sometimes represented as twining around the trunk and branches of the elm: Titania says

"___ The female ivy so

Enrings the barky fingers of the elm."

We are told, too, that notwithstanding their female nature, no jealousy attends this rivalry :

* It will be observed that round is here used in the sense of surround. 
"The lusty vine, not jealous of the ivy, Because she clips the elm."

Lover's Progress; Beaumont and Fletcher.

Whatever be the cause, however, another poet tells us that

“____ Everlasting hate

The vine to ivy bears."

Philirs's Cyder.

Milton celebrates the shade of this beautiful tree:

"Nor always city-pent, or pent at home, I dwell; but when spring calls me forth to roam, Expatiate in our proud suburban shades Of branching elm, that never sun pervades."

Elegy to C. Deodati.

" Figon invites me to the bazel grove, Amyntas, on the river's bank to rove, And young Alphesibreus to a seat

Where branching elms exclude the mil-day heat." Poem on the Death of C. Deodati.

Blair gives a most shivering description of an Elm old and decayed :

"Quite round the pile, a row of reverend elms, Coeval near with that, all ragged show, Long lashed by the rude winds; some rift half down Their branchless trunks; others so thin atop, That scarce two crows could lodge in the same tree."

The Grave.

W. Browne gives it a benevolent character :

“There stood the elme, whose shade, so mildly dim, Doth nourish all that groweth under him." 


\title{
FIR TREE.
}

\author{
PINUS.
}

CONIFERE.

MONECIA MONADELPHIA.

French, sapin ; Italian, abeto.

The Silver Fir, Pinus picea, is a noble upright tree: the branches are not very numerous, the bark is smooth; the upper surface of the leaves is of a strong fine green, their under-side is marked with two white lines running lengthwise on each side of the midrib, giving a silvery appearance, from which this Fir takes its name. The cones are large, and grow erect. It is a native of Switzerland, Germany, Siberia, Mount Caucasus, \&c.

It has been observed in Ireland, that no tree grows so speedily to so large a size as the Silver Fir. It is reckoned a good timber for boat-building. A gentleman in Hampshire floored his library with Silver Fir fresh felled, and the boards did not contract in the least. A turpentine, called the Strasburg, is obtained from this tree.

The Balm of Gilead Fir, Pinus balsamea, is a beautiful tree; some consider it the handsomest of the Firs while young; it has very much the habit of the Silver Fir; the leaves are wider and blunter, and the cones are not so leng. The leaves and buds are remarkably fragrant. A very fine turpentine, called Canada Balsam, is obtained from it, which is sold for the Balm of Gilead.

This tree is a native of Virginia, where it grows to a 
large size; here, after the first eight or ten years, it makes little progress.

The Black, Pinus nigra, and the White Spruce Fir, Pinus alba, are so named from the colour of their bark; there is little difference in that of the wood; and the under-sides of the leaves are whiter in the black species than in the white. Both are natives of North America; the white, which is much the largest, on the mountains ; the black, on the low grounds, generally in bogs and swamps. From both the sorts exudes a clear resin of a strong scent, much used by the Indians to cure wounds and internal disorders; and the branches of both are indifferently used in making spruce beer.

There is a variety called the Long-coned Cornish Fir.

The Norway spruce, Pinus abies, is the loftiest of our European trees, attaining a height of one hundred and forty or one hundred and fifty feet, with a very straight trunk, and throwing out its spreading branches so as to form an elegant pyramid.

This tree is called the Norway Spruce, because its timber is chiefly imported into this country from Norway. The vast woods of Denmark, Norway, and Sweden, are principally composed of this Fir, and the Pinus sylvestris; which we call the Scotch pine, because it abounds in Scotland, and is the only tree of the genus that is indigenous there.

There are two principal varieties of the Norway Spruce Fir ; the white, and the red; supposed to be so called from the paler or deeper colour of their cones : both afford the white deals; the red deal is the timber of the Pinus sylvestris, and is of a much superior quality.

Fir was formerly used for building ships, and still is in use for masts, and some other parts, but seldom for 
entire vessels, unless in small craft. The chief consumption of deal now is for the interior work of our houses, and some articles of household furniture. It is a smooth wood to polish, and is therefore thought good for gilding: it takes black as well as the wood of the peartree, and is approved for carving, the grain being easy to work: it is thought to be more easily wrought, and to take glue better than any other wood. It yields pitch, tar, turpentine, and resin ; and from the buds and tops spruce beer is made, which is considered an excellent remedy for the scurvy. Even the fresh cones boiled in whey are considered efficacious in cases of scurvy.

The air impregnated with the exhalations of Fir-trees is by some persons considered very wholesome, especially for persons of delicate lungs.

The Abbé Barthelemy says, in speaking of Arcadia, "Ce pays produit presque tous les arbres connus. Les habitans, qui en font une étude suivie, assignent à la plupart des noms particuliers; mais il est aisé d'y distinguer le pin, le sapin, le cyprès, le thuja, l'andrachne, le peuplier, une sorte de cedre dont le fruit ne mûrit que dans le troisième année. J'en omets beaucoup autres qui sont également communs, ainsi que les arbres qui font l'ornement des jardins. Nous vîmes, dans une vallée, des sapins d'uné grosseur et d'une hauteur extraordinaires : on nous dit qu'ils devaient leur accroissement à leur heureuse position; ils ne sont exposés ni aux fureurs des vents ni aux feux du soleil."

Voyagge d'Anacharsis, ch. 52.

This country produces almost all known trees; the inhabitants, who make a constant study of them, assign particular names to 
most of them; but it is easy to distinguish the pine, the fir, the cypress, the arbor-vitæ, the andrachne, the poplar ; a sort of cedar, the fruit of which ripens every third year ; and many others equally well known, which, as well as the trees more peculiarly belonging to the garden, I omit. We saw in a valley some firs of a prodigious size and height; and were told they owed their extraordinary growth to their excellent situation, being neither exposed to the fury of the winds nor to the scorching heat of the sun.

Dr. Clarke, in his Travels in Sweden, Norway, \&c. describes the simple mode by which the tar is obtained from the roots of the Fir-tree; a mode, he says, exactly similar with that of the ancien $九$ Greeks :

" A conical cavity is made in the ground, generally in the side of a bank or sloping hill, and the roots of the Fir, together with logs or billets of the same, being neatly trussed into a stack of the same conical shape, are let into this cavity. The whole is then covered with turf, to prevent the volatile parts from being dissipated, which, by means of a heavy wooden mallet, and a wooden stamper, worked separately by two men, is beaten down, and rendered as firm as possible above the wood. The stack of billets is then kindled, and a slow combustion of the Fir takes place, without flame, as in making charcoal. During this combustion, the tar exudes; and a cast-iron pan being at the bottom of the funnel with a spout, which projects through the side of the bank, barrels are placed beneath this spout, to collect the fiuid as it comes away. As fast as the barrels are filled, they are bunged, and ready for exportation."

To the Norwegian peasants the Fir is of singular utility : Dr. Clarke observes, that " their summum bonum seems to consist in the produce of the Fir. This tree 
affords materials for building their houses, churches, and bridges, for erery article of their household furniture, for constructing sledges, carts and boats, besides fuel for their hearths. With its leares they strew their floors, and afterwards burn them, and collect the ashes for manure."

Sir William Ouseley describes the houses of the peasants in Turkey as being frequently built of pine or Fir trees; and says also, that " pieces of resinous Fir tree wood supplied the place of candles at Bedrowâs."

Hall, in his "Travels in Scotland, says, "Among the better sort of people, tallow candles, and oil lamps, as well as wax candles, are sometimes used; but, as it is not only cheaper, but gives a better light, many upon ordinary occasions use only pieces of Fir, split thin, from the roots of trees found in the mosses; which, from the great quantity of the resinous and inflammable matter they contain, give excellent light. It is the business of the young people in the house to prepare and hold these candles, one of which affording nearly as much light as a torch, generally serves all in any one roon of the house. Agreeably to this notion, when a rich man in London lately was extolling the candlesticks on the table, which were of massy silver, elegantly carved; a gentleman from Strathspey being present, said that these were not so valuable as the candlesticks in many parts of the Highlands of Scotland. A thousand guineas were immediately laid, that there were not better nor more valuable than those in all the Highlands. The gentleman who held the bet was allowed a sufficient time for the candlesticks to be brought to London for inspection, and proof that they had been used in the Highlands previously to the staking of the thousand guineas. When the evening 
of the day arrived that the Highland candlesticks were to be inspected, four uncommonly handsome young men, in elegant Highland dresses, unexpectedly entered the room with blazing torches of fir in their hands. It was universally agreed that these were the candlesticks used in the Highlands, and those referred to when the bet was laid, and also that they were the most valuable. The gentleman, therefore, who proposed it, lost the bet."

Vol. ii. p. 440.

Wordsworth notices the strong outline made by the dark Fir in the dusk of evening, which makes it one of the last objects visible :

"Unheeded night has overcome the vales :

On the dark earth the baffled vision fails;

The latest lingerer of the forest-train,

The lone black fir forsakes the faded plain."

Vol. i. p. 67.

He thus addresses an absent friend :

"And now I call the pathway by thy name, And love the fir-grove with a perfect love; Thither do I withdraw when.cloudless suns Shine hot, or wind blows troublesome and strong: And there I sit at evening, when the steep Of Silver-how and Grasmere's placid lake, And one green island, gleam between the stems Of the dark firs-a visionary scene."

Vol. ii. p. 279.

The soft murmuring of the winds in trees of this genus has been noticed repeatedly:

"While o'er my head

At every impulse of the moving breeze

The fir-grove murmurs with a sea-like sound, Alone I tread this path.

WoRDSWORTH, ii, 280. 


\section{Virgil, speaking of different soils, says}

" At sceleratum exquirere frigus

Difficile est; picex tantum, taxique nocentes Interdum, aut hederæ pandunt vestigia nigræ."

It is hard to discorer the pernicious cold; only Fir trees, and yews, and black ivy sometimes will indicate it.

Fawkes uses an epithet peculiarly applicable to its growth :

" Here spiry firs extend their lengthened ranks ;

There violets biossom on the sunny banks."

Bramham Park.

Fairfax terms it the "Weeping Fir ;" in allusion to the turpentine that flows from it when wounded: Spenser also speaks of it as

"The fir that weepeth still."

W. Browne calls it

"The firre that oftentimes doth rosin drop."

The following evidently alludes to its use in shipbuilding :

" Th' adventurous fir that sails the vast profound."

Harte's Statius, b. 6.

Drayton speaks of it as the tree of Mars:

"Fair Venus' myrtle, Mars his warlike fir, Minerva's olive, and the weeping myrrh."

Mr. Keats, with that poetic power which expresses much in a few words, describes to us the constant occupation of the Fir tree in the fruit season:

"__ - Fir trees grow around,

Aye dropping their hard fruit upon the ground." 
It cannot therefore be said of the Fir tree as Voltaire said of his trees at Ferney, when being complimented upon their quick growth, he answered that they had nothing else to do but to grow. 


\section{GLYCINE.}

Glycine is of Greek origin, and signifies sweet.-French, haricot en arbre; Italian, glicine.

THe shrubby Glycine, Glycine,frutescens, or Carolina Kidney-bean Tree, was introduced here in 1724, by Mr. Catesby; it has woody stalks which twist themselves together, and twine round any trees that grow near, and will rise to the height of fifteen feet or more. The leaves somewhat resemble those of the ash in shape; purple flowers are produced in clusters from the axils, which are succeeded by legumes shaped like those of the scarlet kidney-bean, containing several seeds; but these do not ripen in England. 


\section{HARE'S EAR.}

\section{BUPLEURUM.}

French, bupleure; Italian, bupleuro.

Shrubby Hare's Ear, or Ethiopian Hartwort, Bupleurum fruticosum, is an evergreen shrub five or six feet high, and branching into a large regular bush; the bark is of a purplish colour; the leaves are sea-green; they are about four inches long and one broad, placed alternately on the branches, oblong, smooth, stiff, and shining. The branches are terminated by umbels or bunches of flowers, first yellow, but fading to brown; these blow in July or August, but seldom produce ripe seeds in England. It is a native of the Levant, Italy, and the South of France. Gerarde cultivated it in his garden in 1596, by the name of Shrub Sesely, or Ethiopian Hart-Wort ; and compares the leaves, both for shape and substance, with those of the oleander. 


\title{
HAWTHORN.
}

\author{
CRAT EGUS.
}

ROSACEE.

ICOSANDRIA DIGYNIA.

French, neflier; Italian, lazerolo.

In addition to the common Hawthorn, or White-thorn, so deservedly admired as one of the earliest and greatest ornaments of our hedges in the spring, and one of the latest in the autumn (for the berries are perhaps even more beautiful than the blossoms; not to mention the numbers of warbling guests that sit upon the boughs, and feed on them), our plantations boast of several American species, which, though none, perhaps, can vie with our own in beauty, serve to make an agreeable variety.

The Great American, or Scarlet Fruited Hawthorn, Cratogus coccinea, grows about twenty feet high in this country; the flowers are large, come out in large clusters, and make a handsome show in the month of May: these are succeeded by a large pear-shaped fruit, of a brilliant scarlet colour, which ripens in September. The leaves in the autumn turn to a brown red. This was first cultivated in England by Mr. J. Robert in 1696.

The Great-fruited Hawthorn, Cratç introduced here in 1746, by Archibald, Duke of Argyle, Its fruit is orange-red, dotted with brown; it has no thorns.

The blossoms of the Woolly-leaved Hawthorn are 
small, and blow in June; the fruit ripens late in autumn. There is a variety of this with larger blossoms and fruit, and no thorns, called the Carolina Hawthorn.

The Cockspur Hawthorn, Cratagus crus-galli, which was cultivated in this country in 1691 , by Mr. Charles Howard, has fine blush-coloured flowers, or white tinged with blush-colour; the fruit is globular, and of a bright red. This also blows in May.

The branches of the Maple-leaved Hawthorn, Cratog'ls cordata, are spotted with white: this was raised in the Chelsea Garden in 1\%38, from seeds sent from America, by the title of New Haw. It flowers late in May, and the fruit ripens late in autumn.

The Pear-leared sort, Cratcegus pyrifolia, and Ovalleaved, Cratcegus elliptica, were introduced by Messrs. Kennedy and Lee in 1765.

The Hollow-leaved, Cratagus glandulosa, flowers in May and June: it was cultivated here in 1750. The Yellow pear-berried, which blossoms in May, was not known in this country until 1758.

The Gooseberry-leaved Hawthorn, Cratagus parvifolia, has very small leaves; the flowers come out two or three, or even one at a time; the fruit is small, and of a green yellow colour. Some of the plants were raised in Bishop Compton's garden at Fulham, from seeds sent by Mr. Banister from Virginia, at the beginning of the eighteenth century.

These are all Americans.

Quickset hedges are of great antiquity. Evelyn says, the Hawthorn, Whitethorn, or Cratagus oxyacantha, was accounted one of the fortunate trees, and used at nuptial feasts, "since the jolly shepherds carried the 
Whitethorn at the rape of the Sabines, and ever after considered propitious."

When Ulysses, on his return to his native land, went to see his father Laertes, the old man is represented alone in his garden, having sent his men to gather thorns from the woods :

"Nor aged Dolius, nor his sons were there,

Nor servants, absent on another care ;

'To search the woods for sets of flowery thorn, Their orchard bounds to strengthen and adorn"

Pope's Homer's Odyssey, book xxiv.

Goldsmith, in his Deserted Village, describes the Hawthorn in a lively manner:

"The hawthorn-bush, with seats beneath the shade,

For talking age and whispering lovers marle!

How often have 1 blessed the coming day, When toil remitting lent its turn to play, And all the village-train from labour free, Led up their sports beneath the spreading tree;

While many a pastime circled in the shade, The young contending, as the old surveyed."

The following lines describe the appearance of this tree on the first of April :

"Fringing the forest's devious edge,

Half-robed appears the hawthorn hedge;

Or to the distant eye displays

Weakly green its budding sprays."

T. WARTON.

Observe the words of a king:

"Gives not the hawthorn-bush a sweeter shade To shepherds, looking on their silly sheep, Than doth a rich embroidered canopy To kings, that fear their subjects' treachery? 
$O$ yes it doth; a thousand fold it doth; And, to conclude, - the shepherd's homely curds, His cold thin drink out of his leathern bottle, His wonted sleep under a fresh tree's shade, All which secure and sweetly he enjoys, Is far beyond a prince's delicates."

Third Part-Henry Sixth.

The Hawthorn is always associated with the idea of tranquil ease, or rural sports :

"Come, my Corinna, come, and coming, mark

How each field turns a street, each street a park, Made green, and trimmed with trees; see how

Devotion gives each house a bough

Or branch ; each porch, each door, ere this, An ark, a tabernacle is ;

Made up of Whitethorn neatly interwove."

HERRICK's Hesperides.

The beautiful blossoms of the Whitethorn very much resemble the cherry-blossom, or that of the myrtle. Sometimes indeed they are deeply tinted with rosecolour, but they are much more generally white:

"Between the leaves the silver Whitethorn shows Its dewy blossows pure as mountain snows."

KLEIS T's Spring *.

The Glastonbury Thorn, which is an early variety of the Cratagus oxyacantha, is said to have been originally the staff of Joseph of Arimathea. According to the tradition of the Abbey of Glastonbury, he came to Britain, attended by twelve companions, and founded, in honour of the Blessed Virgin, the first Christian church in this island. As a proof of his mission, he is said to

* See Time's Telescope for 1820, p. 171. 
have stuck his staff into the ground, which immediately shot forth, and blossomed. By some credulous persons, this tree was long thought to put forth its blossoms annually on Christmas day; but this deceit has now lost its credit, even with the ignorant. 


\title{
HAZEL-NUT TREE.
}

\author{
CORYLUS.
}

French, coudrier, noisetier ; Italian, nocciolo.

THE common Hazel, Corylus avellana, grows wild in many woods and coppices in England, where the fruit is gathered in great plenty by the country people, and sent tc the London markets.

The trunk of the Hazel is corered with a whitish cloven bark, which is smooth on the branches, frequently of a bay colour, and spotted with white. The leaves are alternate, serrate or wrinkled, hairy on both sides, dark green above, a paler green on the under side; on very hairy round foot-stalks, about an inch long; on the lower side of the leaf is a white hairy midrib, from which proceed several white nerves, and between these is a kind of veiny net-work.

When this shrub is allowed time for growth, it will furnish poles twenty feet in length; but it is generally cut down long before it attains that height, for walkingsticks, fishing-rods, \&c. The roots are used for inlaying or staining. When yeast is scarce, some persons twist the twigs of the Hazel, steep them in ale during its fermentation, and hang them up to dry; when they are put into the wort, either to assist, or supply the place of, the yeast. The chips are put into wine to purify it.

There are several varieties of the Hazel, the IVhite 
Filbert, the Red Filbert, the Cob, and the Clusternut. The White and Red Filbert are so named from the colour of the outer skin of the kernel. The Cob-nut is very round and large, and the Cluster-nut is produced in large bunches or clusters at the ends of the branches.

Swinburne informs us that Avellana is from Avellino, a city of Naples, in the neighbourhood of which the nuts are cultivated in great abundance; and that in favourable seasons it brings a profit of 60,000 ducats, or 11,250\%. The nuts are principally the large round filbert, which we call the Spanish Filbert. These were originally imported into Italy from Pontus, and known to the Romans by the name of Nux Pontica; which was afterwards changed to Nux Avel:ana, from the place where they had been most successfully cultivated.

Evelyn has a very singular passage concerning the Hazel : after recounting a variety of purposes for which it is well adapted, he continues---

"Lastly, for riding-switches and divinatory-rods for

, the detecting and finding out of minerals (at least, if that tradition be no imposture); it is very wonderful, by whatever occult virtue, the forked stick (so cut, and skilfully held) becomes impregnated with those invisible steams and exhalations, as by its spontaneous bending from a horizontal posture, to discover not only mines, and subterraneous treasure, and springs of water, but criminals guilty of murder, \&c.; made out so solemnly, and the effects thereof, by the attestation of magistrates, and divers other learned and credible persons (who have critically examined matters of fact), is certainly next to miracle, and requires a strong faith. Let the curious, therefore, consult that philosophical treatise of Dr. Valle- 
mont, which will at least entertain them with a world of surprising things.

"But now after all, the most signal honour it was ever employed in, and which might deservedly exalt this humble and common plant abore all the trees of the wood, is that of hurdles, - not for that it is generally used in the folding of our innocent sheep, an emblem of the church,--but for making the walls of one of the first Christian oratories in the world, and particularly in this island, that venerable and sacred fabric of Glastonbury, founded by Joseph of Arimathea; which is storied to have been first composed of a few hazel-rods interworen about certain stakes driven in the ground: and walls of this kind instead of laths and puncheons, superinduced with a coarse mortar made of loam and straw, do to this day enclose divers humble cottages, sheds, and outhouses in the country."

The first part of this quotation is certainly rather extraordinary, but the most extraordinary thing about it is, that such a man should relate it in a manner so serious : this tale might indeed have pleased the active faith of Sir Thomas Browne. It may probably remind the reader of Captain Stedman's mode of discovering theft among his negroes, informing them that the guilty person's nose would very shortly be adorned with a sprouting feather; then secretly watching their actions, and detecting the person by observing him constantly putting his hand to his nose to learn if the proof of his guilt had yet made its appearance there*.

Speaking of the nuts, Evelyn says, "They are brought

* See Stedman's Surinam, vol. ii. 
among other fruit to the best tables for dessert, and are said to fatten, but too much eaten are obnoxious to the asthmatic. In the mean time of this I have had experience, that Hazel-nuts, but the Filbert especially, being full ripe, and peeled in warm water (as they blanch almonds) make a pudding very little, if at all, inferior to that our ladies make of almonds."

The following passage is interesting to an admirer of Evelyn :

"I do not," says he, "confound the filbert Pontic, or filberd distinguished by its beard, with our foresters, or bald Hazel-nuts, which doubtless we had from abroad, and bearing the names of Avelan, Avelin; as I find in some ancient records and deeds in my custody, where my ancestor's' names were written Avelan, alias Evelin, generally."

He observes that the Hazel "srospers well where quarries of freestone lie underneath, as at Hazelbury in Wilts; Hazeling-field in Cambridgeshire; Hazlemere in Surrey, and other places." The places here mentioned are evidently named from the Hazel.

The spreading roots of the Hazel are reckoned very mischievous in a vineyard :

"Neve inter vites corylum sere."

VIRGIL, Georgic ii.

"Plant no hazels among your vines."

The goat also is an enemy to the vineyard, and on that account was sacrificed by the Romans to Bacchus; and the entrails were roasted on hazel spits. They used hazel twigs to bind the vines.

Thomsen, describing the birds preparing nests for their young, says, 
« Among the roots

Of hazel, pendent o'er the plaintive streams, They frame the first foundation of their domes:

Dry sprigs of trees, in artful fabric laid, And bound with clay together."

Spring.

Gay, in his Rural Sports, among which, however, he has not included the pleasant one of nutting, slightly mentions the Hazel (as it is generally pictured by the poets), as growing by the margin of a brook :

"O lead me, guard me, from the sultry hours, Hide me, ye forests, in your closest bowers, Where the tall oak his spreading arms entwines, And with the beech a mutual shade combines; Where flows the murmuring brook, inviting dreams : Where bordering hazel overhangs the streams, Whose rolling current, winding round and round, With frequent falls makes all the woods resound."

Thomson gives a pretty picture on this subject :

"Ye swains, now hasten to the hazel bank, Where down yon dale, the wildly winding brook Falls hoarse from steep to steep. In close array, Fit for the thickets and the tangling shrub, Ye virgins come. For you their latest song. The woodlands raise: the clustering nuts for you The lover finds amid the secret shade; And where they burnish on the topmost bough, With active vigour crushes down the tree, Or shakes them ripe from the resigning husk,A glossy shower, and of an ardent brown As are the ringlets of Melinda's hair."

Autumn.

Wordsworth speaks with great delight of the pleasures of nutting : 
66 Among the woods

And o'er the pathless rocks I forced my way, Until at length I came to one dear nook Unvisited, where not a broken bough

Drooped with its withered leaves, ungracious sign

Of devastation ! but the hazels rose

Tall and erect, with milk-white clusters hung,

A virgin scene ! - A little while I stood,

Breathing with such suppression of the heart

As joy delights in ; and with wise restraint, Voluptuous, fearless of a rival, eyed

The banquet,--or beneath the trees I sate

Among the flowers, and with the flowers 1 played:

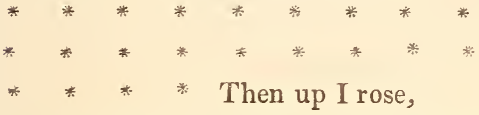

And dragged to earth each branch and bough with crash, And merciless ravage, and the shady nook Of hazels, and the green and massy bower Deformed and sullied, patiently gave up

Their quiet being; and unless I now Confound my present feelings with the past, Even then when from the bower I turned away Exulting, rich beyond the wealth of kings, I felt a sense of pain when I beheld The silent trees, and the intruding sky."

Gay, describing some of the innocent incantations of the shepherds, makes one of his ruddy damsels say -

"Two hazel nuts I threw into the flame, And to each nut I gave a sweetheart's name; This with the loudest bounce me sore amazed, That in a flame of brightest colour blazed.

As blazed the nut so may thy passion grow : For 'twas thy nut that did so brightly glow." 
Chatterton compares the colour of the Filbert to that of a lady's hair :

"Browne as the fylberte droppyng from the shelle,

Browne as the nappy ale at Hocktyde game, So browne the crokyde rynges, that featlie fell

Over the neck of the all beauteous dame."

Battle of Hastings.

The Hazel is well-known as a favourite haunt of the squirrel :

"___ Upon whose nutty top

A squirrel sits, and wants no other shade

Than what by his own spreading tail is made;

$\mathrm{He}$ culls the soundest, dext'rously picks out

The kernels sweet, and throws the shells about."

COWLEY.

We are told by Virgil, and Virgil is a great authority, that the Hazel has been more honoured than the vine, the myrtle, or the bay itself :

"Populus Alcidæ, gratissima vitis Iaccho

Formosæ myrtus Veneri, sua laurea Phœbo;

Phyllis amat corylos; illas dum Phyllis amabit,

Nec myrtus vincet corylos, nec laurea Phœbi."

Eclogue vii.

Rendered by Dryden :

"The poplar is by great Alcides worn;

The brows of Phœbus his own bays adorn;

The branching vine the jolly Bacchus loves:

The Cyprian queen delights in myrtle groves;

With hazel Phyllis crowns her flowing hair;

And while she loves that common wreath to wear,

Nor bays, nor myrtle boughs with hazel shall compare."

There is one great virtue in the Hazel-nut, which we have pleasure in making known to our readers. It is true 
that taste differs with regard to personal beauty as in all things else; and in the colour of the eye, as in other beauties of person: some authors, indeed, have lauded the grey eye; Chaucer appears to prefer this colour; but poets in general are divided between the blue and the black. We are sorry we cannot give our readers a recipe to turn the eye blue; but to those fond mothers who admire black, and have mourned over the grey eyes of their infant children, we recommend to burn to ashes the shells of hazel-nuts, and to apply them to the hinder part of the head of the grey-eyed child. Tradition, who is aged, and should have experience, affirms that they will change the eyes from grey to black. 


\section{HOLLY BUSH.}

ILEX.

ILICIDE.E.

TETRANDRIA TETRAGYNIA.

French, le houx, le grand housson, l'agron, le grand pardon, bois franc; Italian, agrifoglio, alloro spinoso; English, holly, holme, or hulver.

THE Common Holly, Ilex aquifolium, at full growth, is generally from twenty to thirty feet high; yet it is sometimes seen as high as sixty feet. The general appearance of this tree is well known. When the Holly grows naturally, and is old, the upper part of the tree is clothed with entire leares, without thorns, only ending in a sharp point. The flowers, which are of a dingy white, appear in May, in clusters of three, four, or five, and are succeeded by roundish berries, which, about Michaelmas, turn to a beautiful scarlet; and these, when not eaten by the birds, will hang on great part of the winter.

The Holly is a native of this country, and many other parts of Europe, of North America, Japan, CochinChina, \&c.

" It grows so spontaneously in this part of Surrey," says Evelyn, "that the large vale near my own dwelling was anciently called Holmesdale. In Dungeness, in Kent, it grows even among the pebbles on the beach."

The Holly should be in every shrubbery or plantation, for the beauty of its shining evergreen leaves, and of its scarlet berries, will still remain when little vegetation is to be seen: and if a few of the best varieties of variegated 
Holly be intermixed with the plain, they will add to the beauty.

This tree is excellent for a hedge or fence, and would be preferable to the hawthorn for the purpose, were it not for its slow growth while young, and the difficulty of transplanting it after infancy. "Is there under heaven," says Evelyn, " a more glorious and refreshing object of the kind than an impregnable hedge of about four hundred feet in length, nine feet high, and five in diameter ; which I can show in my now ruined gardens at Sayes Court (thanks to the Czar of Muscory*), at any time of the year, glittering with its armed and varnished leavesthe taller standards at orderly distances, blushing with their natural coral? It mocks the rude assaults of the weather, beasts, or hedge-breaker."

"A hedge of holly thieves, that woull invade, Repulses like a growing palisade:

Whose numerous leaves such orient green invest As in deep winter do the spring arrest."

\section{CoWley.}

"Seven years," says Evelyn, "we wait for a quickset hedge; it is worth staying thrice seven for this, which has no competitor."

The timber of the Holly is in great esteem with the millwright, turner, and engraver; it takes a fine polish, and is well adapted for several kinds of furniture. Miller mentions a room floored in compartments of holly and

* The Czar, Peter the Great, resided at Mr. Evelyn's house, in order to be near the dock-yard at Deptford during his stay in England. The garden appears not to have improved under his care. Indeed it is said that the Emperor took great delight in the very elegant amusement of being wheeled in a barrow through the thick holly-hodges, which were the pride of the garden. 
mahogany, which had a very pretty effect. It is much used, as well as box, yew, whitethorn, \&c. in the little toys and trinkets called Tunbridge-ware. It is also of much use in veneering, and is stained to imitate ebony.

Of the green bark, boiled and laid in the damp to ferment, bird-lime is made.

The varieties of the Common Holly are innumerable, and in the multiplicity of names, might vie with the tulip or hyacinth; but a repetition of mere names would be of little interest to the reader: the chief varieties are the gold and the silver-edged, the hedge-hog, and that with yellow berries, the painted lady, the glory of the west, Cheyne's Holly, \&c.

The Dahoon Holly, Ilex Dahoon, produces no fruit in this country, where it was introduced in 1726. There are two species of Carolina, Ilex cassine, and Ilex opaca, one of which is deciduous.

The South Sea Holly, South Sea tree, or Evergreen Cassine (Ilex vomitoria), is scarcely hardy enough for our climate, and cannot be trusted in the open air till it is several years old. The leaves of these are about the size, texture and colour of those of the small-leaved Alaternus : it is a native of West Florida, Carolina, and some parts of Virginia, particularly near the sea. These leaves are preferred, as a substitute for tea, to those of the cassine or cassioberry bush, because they are less bitter.

It is said that the Indians consider this tree as a panacea; at certain times of the year they hasten in droves to the coast, from a distance of three hundred miles; they make a fire upon the ground, and putting a kettle of water on it, they throw in a large quantity of these leaves, and, sitting round the fire, they begin to drink large draughts from a pint bowl which they have with 
them : in a short time this occasions vomiting; they repeat this for two or three days, and then every one taking a bundle of the leaves away with him, they all return to their habitations.

"This plant," says Miller, "is supposed to be the same as that which grows in Paraguay, where the Jesuits make a great revenue of the leares: an account of which is given by Mons. Frezier."

The Cape Holly (Ilex crocea), called by the natives Geelhoust, or Yellow-wood, affords excellent timber of a yellow colour, and close texture, very like boxwood. It is much used in Caffraria, as well for the beams and planks in building houses, as for various articles of household furniture*.

Southey has noticed the difference of the upper leaves in old Holly trees :

"O Reader! hast thou ever stood to see

The holly-tree?

The eye that contemplates it well perceives

Its glossy leaves,

Ordered by an Intelligence so wise,

As might confound the atheist's sophistries.

Below a circling fence its leaves are seen

Wrinkled and keen;

No grazing cattle through their prickly round

Can reach to wound;

But as they grow where nothing is to fear,

Smooth and unarmed the pointless leaves appear.

I love to view these things with curious eyes

And moralize:

And in this wisdom of the holly-tree

Can emblems see

Wherewith perchance to make a pleasant rhyme,

One which may profit in the after-time.

* 'Thunberg's Travels, vol. i. p. 109. 
Thus, though abroad perchance I might appear Harsh and austere,

To those who on my leisure would intrude

Reserved and rude,

Gentle at home amid my friends I'd be,

Like the high leaves upon the holly-tree.

And should my youth, as youth is apt I know,

Some harshness show,

All vain asperities I day by day

Would wear away,

Till the smooth temper of my age should be

Like the high leaves upon the holly-tree.

And as when all the summer trees are seen

So bright and green,

The holly leaves their fadeless hues display

Less bright than they;

But when the bare and wintry woods we see,

What then so cheerful as the holly-tree?

So serious should my youth appear among

The thoughtless throng;

So would I seem among the young and gay

More grave than they;

That in my age as cheerful I might be

As the green winter of the holly-tree."

Wordsworth also praises the Holly :

"Where leafless oaks towered high above,

I sate within an under-grove

Of tallest hollies, tall and green;

A fairer bower was never seen.

From year to year the spacious floor

With withered leaves is covered o'er,

You could not lay a hair between:

And all the year the bower is green.

But see where'er the hailstones drop

The withered leaves all skip and hop, 
There's not a breeze-no breath of air-

Yet here-and there-and everywhere-

Along the floor beneath the shade

By these embowering hollies made :

The leaves in myriads jump and spring,

As if with pipes and music rare

Some Robin Good-fellow were there!

And all those leaves in festive glee

Were dancing to the minstrelsy."

WORDSWORTH, vol. i. p. 240.

W. Browne speaks of the Holly as an enemy to the husbandman, at the same time commending it as a fence:

"Under the hollow hanging of this hill

There was a cave cut out by nature's skill,

Or else it seemed the mount did open 's breast,

That all might see what thoughts he there possest.

Whose gloomy entrance was environed round

With shrubs that cloy ill husbands' meadow ground:

The thick-growne hawthorne, and the binding bryer,

The holly that outdares cold winter's ire:

Who all intwinde, each limbe with limbe did deale

That scarce a glimpse of light could inward steale." 


\section{HORNBEAM TREE.}

\section{CARPINUS.}

Carpinus from carpere, to crop.-French, charme, charmille; Italian, carpino ; English, hornbeam, hardbeam, horse-beech, hornbeech, wych-hazel, or witch-hazel, and yoke-elm.

The leaf of the Hornbeam, Carpinus betulus, is very similar to that of the elm (in which genus old Gerarde would fain have it placed) : it begins to appear about the end of March, and by the middle of April the tree is in full leaf; towards the end of that month, it is in full blossom also. It retains the old leaves till driven off by the new.

This tree is very common in many parts of England, but is so constantly pollarded by the country people, that it is seldom suffered to attain a handsome growth. When they escape the hands of these executioners, they will grow, especially in a stiff clayey soil, to a height of seventy feet, with large noble stems, perfectly straight and sound.

Fawkes alludes to the regular growth of the Hornbeam hedge, in his Bramham Park:

" Here spiry firs extend their lengthened ranks, There violets blossom on the sunny banks;

Here hornbeam hedges regularly grow,

There hawthorn whitens, and wild roses blow."

Martyn observes, that of late years this tree has only 
been cultivated "for underwood in the country, and in the nurseries to form hedges after the French taste; for in most of their great gardens, their cabinets, \&c. are formed of these trees, as are their trellises and hedges which surround the plantations. But since these sort of ornaments have been banished from the English gardens, there has been little demand for these trees in the nurseries."

The Eastern Hornbeam, Carpinus orientalis, is of humbler growth, and has smaller leaves.

The Hop Hornbeam, so named from the form of its fruit, was first observed in Italy, is very common in Germany, and is said to grow in abundance in many parts of North America. It is of quicker growth than the common Hornbeam, and sheds its leaves with the generality of deciduous trees.

The Virginian Flowing Hornbeam, Carpinus Americana, is of quicker growth than either of the former sorts: it sheds its leaves in autumn, about the same time with the elm, and during the season of its verdure has a handsome appearance, being well clothed with leaves, which are of a deep green colour, similar to those of the longleaved elm.

The other kinds are, in this country, commonly budded on the Common Hornbeam; which, however, is the best for cultivation, as it will grow to a larger size, and also will thrive upon cold, exposed, and barren hills, and resist violent winds better than most trees. The timber is tough and flexible, and when suffered to grow large, may be converted to many useful purposes. Hitherto it has been used chiefly for turnery ware, tool-handles, yokes, \&c. It is also an excellent fuel.

Gerarde says, it was used to yoke oxen, as well by the 
Romans in old times, as in his own time and country; therefore, and from the form of the leaf, he calls it the Yoke Elm. He recommends the wood for arrows and shafts, and observes that it grows so hard and tough with age as to be more like horn than wood, and that for this reason it was called Hornbeam or Hardbeam. Evelyn says, it was termed Horse-beech, from the resemblance of the leaf to that of the beech tree; from which, however, it is very different. The beech leaf narrows, somewhat like an egg, towards the foot-stalk; whereas the leaves of the Hornbeam and of the elm are broader towards that end than the other. There is otherwise much similarity in all these leaves, as also in the birch leaf, but that it is smaller. The name of Witch-hazel is peculiar to Essex ; the tree commonly called by that name is the broad-leaved Elm, also named Wych Elm.

The German husbandman has a peculiar mode of erecting a fence of Hornbeam; he plants the young trees in such a manner as that every two may be brought to intersect each other in the form of a St. Andrew's cross ; in the part where they cross, he scrapes off the bark, and binds them closely together with straw; the two plants thus connected form a sort of indissoluble knot, and push from thence horizontal slanting shoots which form a living palisado: a rural fortification, as Dr. Hunter terms it. Thesehedges being annually and skilfully pruned, will in a few years become a fence impenetrable in every part. It is not uncommon to see high roads in Germany thus fenced for miles together.

Evelyn observes, that before the entries of many of the great towns in Germany they plant clumps of these trees, "to which they apply timber frames for the convenience of the people to sit and solace in." 
This delightful author occasionally indulges in such eloquent raptures in speaking of the works of nature, that it were difficult to forbear quoting.

"That admirable espalier hedge in the long middle walk of the Luxembourg Garden at Paris, than which there is nothing more graceful, is planted of this tree; and so is that cradle or close walk, with that perplexed canopy, which lately covered the seat in his Majesty's garden at Hampton Court, and as now I hear, they are planted in perfection at New Park, the delicious villa of the noble Earl of Rochester, belonging once to a near kinsman of mine, who parted with it to King Charles the First, of blessed memory. An oblong square palisaded with this plant or the Flemish ornus, as is that I am going to describe, and may be seen in that inexhaustible magazine at Brompton Park (cultivated by those two industrious fellow gardeners, Mr. London and Mr. Wise), affords such an umbraculum frondium, the most natural proper station and convenience for the protection of our orange trees, nyyrtles, and other rare perennials and exotics, from the scorching darts of the sun, and heat of summer : they are so ranged and disposed as to adorn a noble area of a most magnificent Paradisian dining-room, to the top of hortulan pomp and bliss, superior to all the artificial furniture of the greatest prince's court. Here are the Indian narcissus, tuberoses, Japan lilies, jasmines, jonquils, periclimena, roses, carnations, with all the pride of the parterre; intermixt between the tree cases, flowering vases, busts, and statues, entertain the eye, and breathe their redolent odours and perfumes to the smell. The golden - fruit, the apples of the Hesperides, together with the delicious ananas, gratify the taste, while the cheerful ditties of canorous birds, recording their innocent amours 
to the murmurs of the bubbling fountain, delight the ear. At the same time the charming accents of the fair and virtuous sex, preferable to all the admired composures of the most skilful musicians, join in concert with hymns and halleluiahs to the bountiful and glorious Creator, who has left none of the senses which he has not gratified at once with their most agreeable and proper objects."

The wood of the Hornbeam is very inflammable, and will burn like a candle, for which purpose it was formerly used. In the north of Europe, the inner bark is used to dye yellow. 


\title{
HORSE-CHESTNUT TREE.
}

\author{
ESCULUS.
}

HIPPOCASTINEE.

HEPTANDRIA MONOGYNIA.

Asculus, from esca, food. It was formerly named Castanea equina, from the similitude of the fruit to that of the common chestnut, and from its being eaten by horses. Hippocastanum has the same signification: this was formerly the generic name: now it is only the specific name for the common Horse-Chestnut. French, the common kind, marronier; the others, pavia: Italian, the common kind, castagno d'India; the other sorts, ippocastano.

The common Horse-Chestnut (Esculus hippocastanum) is generally considered as one of the most ornamental trees in our plantations. The branches of this tree, when it stands singly, are disposed in a beautiful form; the large palmated leaves, which are composed of seven leaflets, gradually decreasing in size from the middle one to the outer ones; and their elegant drooping: position, contrasted by the large upright pyramidal thyrsus of flowers, variegated towards the centre with yellow or red, are truly magnificent.

"For in its honour prodigal nature weaves A princely vestment, and profusely showers O'er its green masses of broad palmy leaves, Ten thousand waxen pyramidal flowers; And gay and gracefully its head it heaves Into the air, and monarch-like it towers."

Howıтr's Forest Minstrel. 
The capsule, or seed-vessel, is divided into three cells, in which lie the nuts, two of which are generally sacrificed to the welfare of their third companion; these nuts are no less beautiful, when fresh, than is the tree that bears them: many of these nuts have the appearance of the most elegantly veined and finely polished mahogany.

Martyn remarks, that this tree has not of late been so much planted in avenues and walks as formerly, on account of the early falling of the leaves, which makes a litter under them, even from July till they all have fallen; but notwithstanding this inconvenience, says he, the tree has great merit, for it affords a noble shade very early; and during the time of flowering, no tree has more beauty.

Another inconvenience attending this noble tree is, that it does not well resist violent and stormy winds; yet it looks best when standing apart, where the branches have room to spread. The blossoms appear in May, or, as the poet will have it, in June; and continue in beauty a month or more.

"In June that chestnut shot its blossomed spires Of silver upward, 'mid the foliage dark, As if some sylvan deity had hung Its dim umbrageousness with votive wreaths."

D. M. MoIr.*

Mr. Gilpin is no great admirer of this tree; indeed he rather quarrels with all large-leaved trees. "It forms its foliage," says he, "generally in a round miass, with little appearance of those breaks which contribute to give an airiness and lightness, at least a richness and variety, to the whole mass of foliage. This tree, however, is

* See Time's 'Telescope for 1825, p. 258. 
chiefly admired for its flower, which in itself is beautiful ; but the whole tree together in flower is a glaring object, totally inharmonious and unpicturesque. In some situations, indeed, and among a profusion of other wood, a single Horse-Chestnut or two in bloom may be beautiful. As it forms an admirable shade, it may be of use, too, in thickening distant scenery, or in screening an object near at hand: for there is no species of foliage, however heavy, nor any species of bloom, however glaring, which may not be brought, by some proper contrast, to produce a good effect*."

Dr. Aikin says, "its introduction here has been solely owing to its beauty; in which, at the flowering season, it certainly excels every other tree that bears our climate." Evelyn, and his editor, Dr. Hunter, speak highly of its singular beauty.

"6 I wish we did more universally cultivate the HorseChestnut," says Evelyn; "w which being easily increased from layers, grows into a goodly standard, and bears a most glorious flower, even in our cold country."

"The Horse-Chestnut," observes Dr. Hunter, "6 is a tree of singular beauty; the leaves are large, fine, and palmated, and appear very early in the spring. It is naturally uniform in its growth, always forming its head into a regular parabola. In the spring it produces long spikes of rich and beautiful flowers."

The timber is not very valuable: it is reckoned very good for subterraneous water-pipes, for fuel, and for turnery-ware, for which Dr. Hunter informs us that it is valued in the north at sixpence a foot.

Sheep, deer, and hogs feed greedily upon the nuts; and 
boiled, poultry are fed with them. In Turkey they are ground and mixed with the provender of horses; which, according to Erelyn, is the origin of their name. When these nuts decay, they turn to a kind of jelly, which has been found a good substitute for soap in washing. The bark of the tree is used in tanning leather.

The Horse-Chestnut is of rery quick growth: Martyn mentions some raised from the nut, that, at twelve or fourteen years of age, would shade sereral chairs under their branches; being also covered with flowers.

The Horse-Chestnut was brought from the northern parts of Asia into Europe, about the year 1550; about eight years later it was introduced into Vienna, from whence it migrated to France and Italy; but to us it came directly from the Levant. Gerarde, in his Herbal, speaks of it only as a foreign tree; in Johnson's edition of that work, he says, "Horse-Chestnut groweth in Italy, and in sundry places of the east countries; it is now growing with Mr. Tradescant, at South Lambeth." Parkinson says, "our Christian world first had the knowledge of it from Constantinople." He places it as a fruit-tree in his orchard, with the walnut and mulberry; and how little it was then known (1629) may be learned by his describing the fruit as sweet-flavoured, roasted and eaten as the common chestnut.

This tree is perhaps as unsightly in the winter, when destitute of leares, as it is beautiful in full verdure; the branches appear clumsy and faggot-like: at the ends of the branches, before the leares shoot out, the buds become very turgid and large; from thence they sprout forth, and in three or four weeks the shoot is full grown; after that time it increases, indeed, in size and strength, but not in length. These shoots are sometimes a foot and a 
half long, and the leaves in this space of time are fully expanded. No sooner have the flowers fallen than the buds begin to form for the succeeding year: they continue swelling till autumn, at which season they are covered with a thick tenacious juice, which defends the tender buds from the frost and rain of winter. Upon the first return of warmth in the spring, this juice melts and runs off, leaving the bud at liberty to open. The buds being always formed at the extremity of the branches, plainly indicates that they must not be shortened, as the shoots for the ensuing year would so be entirely cut off.

There are varieties of this tree in the nurseries, both with gold and with silver-striped leaves.

The scarlet Horse-Chestnut, Esculus pavia, grows about twenty feet high; it does not spread its branches to any great extent : the leaves are of a light green, opposite, and on long red foot-stalks. 'The flowers grow at the ends of the branches, also upon long and naked foot-stalks, each sustaining four or five flowers: they are much smaller than in the common species, wholly red, tubulous, without any brim; they blow in June, and are sometimes succeeded by fruit; but it seldom comes to maturity in England.

This tree is from Brazil, Carolina, and Florida; Japan, and sereral parts of the East; and was cultivated here in 1712.

Thunberg observed by the road-side near Copenhagen, " many fine arenues of Horse-Chestnut trees, the trunks of which had been wreathed, when young, into a spiral form at the bottom*." 


\section{I'TEA.}

\section{ITEA VIRGINICA.}

RHODODENDRACEE.

PENTANDRIA MONOGYNIA.

Itea is derived from the Greek, and is so named from the swiftness of its growth.

The Virginian Itea is a shrub six or seren feet high at its full growth, sending out many branches from the bottom of the stem to the top: the leaves are alternate, slightly notched at their edges, light green, and reined. At the extremity of the new shoots are produced five erect spikes of white flowers, three or four inches long, which blow in the month of July. When this shrub is in vigour, it is entirely corered with blossoms in the flowering time, and is exceedingly handsome. It is a native of North America, and was first cultivated in England by Archibald Duke of Argyle, in 1744. 


\section{IVY BUSH.}

\section{H E DERA HELIX.}

CAPRIFOLIE.⿱一𫝀.

PENTANDRIA MONOGYNIA

\section{French, lierre; Italian, ellera.}

The common Ivy is a well known plant, unjustly considered as parasitical, the stem of which will support itself by an abundance of fibres, or holdfasts against trees or walls; or, if no support be near, will creep along the ground, the stalks throwing out roots as they run; so that it is very difficult to eradicate it. While they trail upon the ground, or cling to any support, the stalks are slender and flexible, but when they have reached the top of that by which they rise, they become strong, and form large bushy heads : thus do they clothe and crown many a leafless stump with a beautiful and luxuriant verdure. The leaves of these bushy heads are larger, more of an oval shape than the lower leaves, and are not, like them, divided into lobes; this difference made some old botanists mistake them for different species. While the stalks creep, the Ivy never produces any blossom, and in this state it is called Barren or Creeping Ivy; but when they surmount the support by which they have grown, they produce flowers at the end of every shoot; these are of a yellowish or greenish white, growing in umbels or clusters, and are succeeded by berries, which become black before they are ripe. At first the 
berry is round and succulent, with a purple juice; but afterwards it becomes coriaceous, dry, and obscurely quinquangular, being divided into five cells. In this state it is called Climbing, or Berried Ivy. The trunk of an old Ivy is covered with an ash-coloured bark; that of the young branches is of a green or purple colour. The leaves are alternate, evergreen, glossy, smooth; while the plant creeps three, or five-lobed; but when it quits its support, ovate, or egg-shaped. Linnæus describes them as first spear-shaped, then five-lobed, afterwards three-lobed, and lastly ovate; in this latter state it is called Poet's Ivy, Hedera poetica. 'The leaves, particularly on the younger branches, are often streaked with veins of white, and sometimes tinctured with red.

The Ivy is free-born in every country of Europe, though in some it is not common: Linnæus says it is rare in Sweden. Kalm says that he saw Ivy but once in North America, that was against a stone building, and apparently had been brought from Europe, and planted there. The Americans have an Ivy of their own, which has been brought to this country; but it is a deciduous plant, and bears no comparison with the common Ivy of Europe. Thunberg observed it in Japan, and remarked that the leaves were not lobed.

With us, the Ivy begins to blossom in September, and being so late, affords food to bees, when there is little to be found abroad. The berries increase in size during the winter, and ripen about April, when they are eaten by wild pigeons, blackbirds, thrushes, \&c. Blackbirds and some others build their nests in the stump.

Among the many strange fancies dreamed of old with regard to trees, it has been said, that five Ivy berries 
beaten small, and made hot with some rose-water, in the rind of a pomegranate, being dropt into the ear, on the contrary side, will cure an achirg tooth.

The wood is soft and porous, so as to transmit liquids, if turned of a sufficient degree of thinness; the roots are used by leather-cutters to whet their knives upon. " $O$ Of the roots of Ivy," says Evelyn, "6 which shrub may, with small industry, be made a beautiful standard, are made curiously polished and flecked cups and boxes, and even tables of great value."

Homer describes his heroes as drinking out of a cup made of Ivy-wood.

The beechen cup of Alcimedon had a lid of Iry, carved with grapes :

"The lids are ivy ; grapes in clusters lurk

Beneath the carving of the curious work."

Dryden's Virgil, pastoral iii.

Sheep are fond of Ivy, and in severe weather it is a warm and wholesome food for them; therefore the shepherds in the winter cut down branches for their flocks to browse on. Cato directs that cattle should be fed with it, in scarcity of hay. The ancients held Ivy in great esteem ; it was consecrated to Bacchus, who is represented as crowned with it; and was often twined with the laurel in the poet's wreath. When Bacchus was seized by the pirates, his presence was made manifest by many wondrous changes that took place in different parts of the vessel :

"For first, a fountain of sweet smelling wine

Came gushing o'er the deck with sprightly shine, And odours, not of earth, their senses took.

The pallid wonder spread from look to look; 
And then a vine-tree overran the sail, Its green arms tossing to the pranksome gale: And then an ivy, with a flowering shoot, Ran up the mast in rings, and kissed the fruit, Which here and there the dripping vine let down;

On every oar there was a garland crown."

LEIGH HunT, translated from Homer.

Milton speaks of " the Ivy-crowned Bacchus."

One great charm in the Ivy is, the atiraction its berries offer to birds of song, which are constantly hovering about it with their cheerful harmony. But great as is the renown of this elegant shrub, it is charged with a most destructive and deceitful nature; for while it clings fondly to the tree by which it has risen, it kills it in the manner of the bear, by the strictness of its embrace. On this account it has often been found necessary to destroy it. There is a good paper on this subject in the Transactions of the Linnæan Society, in the eleventh volume: the author of which, Mr. Repton, is inimical to its destruction,-for he justly observes, that it is highly ornamental, and useful to the trees; and that it does not girt them nor rob them of their juices, as it derives the whole of its nourishment from its own roots in the ground, as is shown by the destruction of it, when its stem is cut through by the ignorant and prejudiced. Linnæus affirms that it does no injury to buildings, but this it is not easy to allow; for we see that the branches will make their way into a crevice or defect in the wall, and enlarge it by the gradual increase of their bulk, as by the driving in of a wedge. Robert Bloomfield tells us, that the largest Ivy he ever saw was at Ragland Castle. "In this building," says 
he, " a gigantic stem of Ivy has pushed away the fine fluted work of the kitchen window, and seems to set iron and stone at defiance*." The heavy accusations made against it have given rise to much moralising upon the subject.

"See there the envious world portrayed

In that dark look, that creeping pace!

No flower can bear the ivy's shade-

No tree support its cold embrace.

The oak that rears it from the ground,

And bears its tendrils to the skies,

Feels at his heart the rankling wound,

And in its poisonous arms he dies."

LANGHORNE.

Poets, however, more frequently take delight in lauding its beauty than in quarrelling with its vices. Few have noticed the various habits of its growth : how

" When the oak denies her stay,

The creeping ivy winds her humble way;

No more she twists her branches round,

But drags her feeble stem along the barren ground."

LLOYD.

" In a sweet solitude, beside the flood,

Is a green grove of willows, trunk-entwined

With ivies climbing to the top, whose hood

Of giossy leaves, with all its boughs combined,

So interchains and canopies the wood

That the hot sunbeams can no access find;

The water bathes the mead, the flowers around

It glads, and charms the ear with its sweet sound."

WIFFen's Garcilasso, p. 268.

* Remains of Bloomfield, vol. ii. p. 25. 


\section{Spenser plants the Ivy in the Bower of Bliss :}

"And over him, Art striving to compare

With Nature, did an arbour green dispred, Framed of wanton ivy, flow'ring fair ; Through which the fragrant eglantine did spred His pricking arms, entrailed with roses red, Which dainty odours round about them threw : And all within with flowers was garnished, That when mild Zephyrus emongst them blew, Did breathe out bounteous smells, and painted colours shew."

SPENSER.

He gives a very delightful picture of it in another passage :

"Emongst the rest, the clamb'ring yvie grew, linitting his wanton arms with grasping hold, Lest that the poplar happely should rew Her brother's strokes, whose boughs she doth enfold With her lythe twigs, till they the top survew, And paint with pallid green her buds of gold."

Spenser's Virgil's Gnat.

The Ivy has certainly a very beautiful and picturesque appearance upon old buildings, particularly where they are too old to fear any injury it might do them; where it often is seen hanging in luxuriant and heavy masses. As on the ruins of an old castle, abbey, or church :

" The little chapel with the cross above, Upholding wreaths of ivy

KeAts.

The epithet reverend is very appropriate to the Ivy, which is a slow grower, and must be old where it crowns the tree it grows by: 
"Mosses, and reverend ivies serpentine

That wreathe your odorous arms round beech and pine, And, climbing, crown their crest."

WIfFen's Garcilasso.

Virgil speaks of the black Ivy as an indication of a cold soil. Martyn observes in a note, that this poet, and many other ancient authors, speak of another plant, called White Ivy, which is quite unknown to us. Tournefort says, that in passing through the herb market at Constantinople, he bought some of the seeds of the Yellowfruited Iry, which is as common there as the common Iry is at Paris. " Pliny informs us," continues he, " that it was the Golden-fruited Iry which was consecrated to Bacchus, and destined to crown the poets: the leaves, as this author remarks, are of a livelier green than those of the common Iry, and the bunches of goldcoloured berries give it a peculiar brilliancy." In another passage he observes, that Pliny, who gave to this Ivy the name of the Golden-fruited, had not seen the plant, but obtained his information from Theophrastus and Dioscoricles. It appears to be the same which was generally called the White Ivy. " For that which they call the Iry of 'Thrace," observes 'Toumefort, "we saw several of these plants on the coast of the Black Sea ; and it is not surprising that the Bacchantes should formerly have made use of them to adorn their heads or their thyrses, since all Thrace is covered with these plants*."

Tournefort appears to consider the Iry of the ancients only as a variety of the Common Ivy.

A heavy charge indeed may be made against a poet of 
our own times, for some lines which may tend to mislead posterity as to the true poetical Ivy. And unless the matter be here explained, it were hard to say how many quartos would be necessary to make this matter clear in after times.

It has been observed that the leaves of the Poet's Ivy are egg-shaped; yet here is one poet receives an Ivy crown from another poet, and he remarks

"— How they spread

With their broad angles, like a nodding shed Over both eyes!"

Now this does not describe the poet's Ivy, yet he assures us it was with that Ivy he was crowned, and from its luxuriance we might well believe it ; probably the two kinds were intertwined:

"It is a lofty feeling, yet a kind, Thus to be topped with leaves; - to have a sense Of honour-shaded thought, - an influence As from great Nature's fingers, and be twined With her old sacred verdurous ivy-bind, As though she hallowed with that sylvan fence $A$ head that bows to her benevolence, Midst pomp of fancied trumpets in the wind."

Leigh Hunt's Sonnets*.

Let it then be made known to posterity in general, that

"Pallid ivy, building his own bower,"

is but ambitiously striving after the title poetical, which it does not attain until it has reached the top, and roofed the bower. 
We will conclude this article with the following sonnet by our "Village Minstrel," Clare:

" Dark creeping Ivy, with thy berries brown, That fondly twists' on ruins all thine own, Old spire-points studding with a leafy crown Which every minute threatens to dethrone; With fearful eye I view thy height sublime, And oft with quicker step retreat from thence Where thou, in weak defiance, striv'st with Time, And hold'st his weapons in a dread suspense. But, bloom of ruins, thou art dear to me, When, far from danger's way, thy gloomy pride Wreathes picturesque around some ancient tree That bows his branches by some fountain-side: Then sweet it is from summer suns to be, With thy green darkness overshadowing me." 


\section{JUDAS TREE.}

\section{CERCIS.}

The botanical name of this tree is from the Greek, and signifies a little sheath. The French call it gainier, which has the same signification; and arbre de Judée; as we call it Judas tree; because it is said Judas hanged himself upon this tree, which has also been reported of the elder tree. The Spaniards, on account of its beauty, or as Gerarde terms it, its "braveness," call it the tree of love, rather contradictory with the last-mentioned name.

The European Judas tree, Cercis siliquastrum, will grow twenty feet high, dividing into many irregular branches; the bark is dark brown, the leares are of a pale green on the upper, of a greyish colour on the under side; the flowers are papilionaceous, of a bright purple, and very beautiful ; they come out in the spring in large clusters on every side of the branches, and often of the stem also, and are in full blow before the leaves have attained half their size. These are succeeded by long flat pods, containing each one row of seeds; but in this country the pods are seldom seen upon the standard trees, because the birds commonly pick off the flowers as soon as they are full blown. Where they are planted against the wall, they will produce pods, which in warm seasons ripen very well. This tree deserves a place in every shrubbery or pleasure-garden, being indeed singularly handsome; when of a good size, it is so productive of flowers as to be sometimes closely covered 
with them, and the shape of the leaves, somewhat like those of the cyclamen, helps also to make a pretty variety in the summer. When planted as a standard, this tree blossoms in May, but against a wall it will be some weeks earlier. The wood is beautifully veined with black and green ; and taking a fine polish, may be converted to many uses. The flowers have an agreeable poignancy, and are eaten in salads.

There are two varieties of this tree, one with fleshcoloured, and one with white blossoms, but they cannot compare with the first in beauty. It is a native of the Levant, Spain, South of France, Italy, \&c. and was cultivated by Gerarde in this country, in 1596.

The American Judas tree, Cercis Canaden:is, grows naturally in North America, where it is called Red-bud tree, from the red flower-buds appearing in the spring before the leaves. This seldom exceeds twelve feet in height in this country, but in its native soil grows much higher. The branches are weaker than those of the former mentioned kind; the leaves are downy, and pointed at the end; the flowers smaller and not so handsome, but the tree is equally hardy.

The blossoms are eaten by the inhabitants of America in salads, and the French in Canada pickle them. The wood is similar to that of the Common Judas tree: the young branches dye wool of a fine nankin colour. This species was not introduced here till about the year 1730 . 


\title{
JUNIPER BUSH.
}

\author{
JUNIPERUS.
}

French, genevrier; Italian, ginepro, ginebro.

THERE are many species of Juniper in our plantations, though some of them are also called by other names. The Spanish Juniper, Juniperus thurifera, grows thirty feet high, and sends out branches, which form a sort of pyramid : the berries, when ripe, are very large and black. This was cultivated by Mr. Miller in 1759 .

The Bermudas Juniper, Juniperus Bermudiana, also called the Bermudas Cedar, has very short leaves, upon four-cornered branches; the berries are of a dark red colour, inclining to purple. The wood has a strong and agreeable odour, and was formerly in great esteem for wainscoting rooms and for furniture. It is of a reddish colour, and is commonly known in this country by the name of Cedar-wood. It is this which is so much in use for holding blacklead pencils. It is a lasting timber, as may be seen by the wainscoting, staircases, \&c. in many old mansions. In old times it was common to have one room wainscoted with this timber, that bore the appellation of the Cedar-room; such are often described by Mrs. Radcliffe.

This was probably the Cedar described by Homer, in the cave of Calypso, as shedding a sweet perfume when Mercury alighted there : 
"And now arriving at the isle, he springs Oblique, and landing with subsided wings, Walks to the cavern 'twixt the tall green rocks, Where dwelt the goddess with the lovely locks. He paused; and there came on him, as he stood, A smell of citron, and of cedar-wood, That threw a perfume all about the isle; And she within sat spinning all the while, And sang a lovely song, that made him hark and smile."

Odyssey, book v. translated by L. Hunt.

The Bermudas Cedar was first cultivated in England in the year 1700, by Lord Clarendon.

The Chinese Juniper, Juniperus Chinensis, is a mere shrub.

The common savine, Juniper sabina, French savinier, cedre à feuilles de cypres, Italian sabina, is a native of the Levant and of the South of Europe. In this country it is from three to five feet high at full growth. The leaves are short, the berries of the same colour as those of the common Juniper, but smaller. The whole plant has a strong unpleasant scent when handled. There is a variety with variegated leaves. Turner speaks of two kinds, a larger and a smaller, of which he had seen the latter in England, and the former in a "preacher's garden in Germany." Professor Pallas says, that in the Chersonesus Taurica it is often seen with a trunk a foot in diameter.

Tournefort says, that in some places this is burnt as common fuel: "L'isle d'Amorgos manque de bois; on n'y brule que de Lentisque, et du Cedre à feuilles de cypres, que la feu devore en un instant*." "The isle of Amorgos has little wood; they burn nothing there but Lentiscus and the common savine, which the flames de-

* Tournefort's Travels, vol. i. p. 287. 
vour in an instant." He says that the Greeks use this wood often when they are fishing: burning it at night to attract the fish by the light*. The wood does not grow on the island, but is brought from Caloyero, Cheiro, and other places in the vicinity.

The Red Cedar, Juniperus Virginiana, is a native not only of North America, but also of the West India islands, and of Japan. It is one of the largest timbertrees in Jamaica. The berry is blue; the bark thin, and breaks off in large pieces. The wood is of a reddish brown, close and firm, shining, and very odoriferous, like the Bermudas Juniper. Like that, too, it is used for wainscoting rooms, making escritoires, cabinets, \&c., cockroaches and other insects disliking the smell of it.

W. Browne, enumerating many trees, speaks of the

" Juniper, where wormes ne'er enter."

This, however, is contradicted by naturalists, who maintain that worms make great havoc with this wood.

This tree is called the Red Cedar in North America, to distinguish it from a kind of cypress (Cupressus, thyoides) which they call the White Cedar. There is a variety of this species, called the Carolina Cedar. This species was cultivated in England in 1664. This may probably be the tree described by Captain Stedman as the Surinam Cedar. He says, though it bears the name of Cedar, it is different from the cedars of Lebanon: that " the Surinam Cedar grows also to a great height, but is principally esteemed because the wood is never eaten by worms or other insects, on account of its great bitterness : it has also an agreeable smell, and is there-

* An interesting description of this mode of fishing, as practised in America, is given in "The Pioneers." 
fore used in preference to most others for making chests, cupboards, lockers, and all sorts of joinery ; besides which it is employed in making the tent-barges, and other boats. The colour of the timber is a pale orange; it is both hard and light, and from the trunk exudes a gum, not unlike the gum arabic, which is transparent, and diffuses a most agreeable odour *."

This does not, however, agree with the Virginian Juniper in the colour of the wood. This author informs us that the houses in Paramaribo are never papered or plastered, but are beautifully wainscoted with Cedar, Brazil, or Mahogany-wood $\uparrow$.

The common Juniper, Juniperus Communis, seldom exceeds three feet in height : the leaves are bright green on one side, and gray on the other: the berries which grow in the axils of the leaves are dark purple; they remain two years on the tree.

It is common in all the northern parts of Europe; in valleys, or on hills; on open sandy plains, or moist enclosed woods; in fertile or in barren soils. In England, it is chiefly found on open downs, in a chalky or a sandy soil. In the south of Europe it is less common, growing only in the more elevated situations.

Though its growth is so very humble in a wild state, it will grow fifteen or sixteen feet high if planted in a good soil. The wood is hard and durable; the bark may be made into ropes. Gin is well known as being flavoured by the berries of this shrub.

There is a variety of the common, called the Swedish Juniper, a native of Sweden, Denmark, and Norway:

* Stedman's Surinam, vol. i. p. 34.7.

$\uparrow$ Ibid. vol. ii. p. 300. 
the leaves are narrower, and not so close together, and the berries are larger than those of the common Juniper: it grows higher, too, than that does in a wild state.

The Brown-berried Juniper, Juniperus Oxycedrus, which the French call Le Cade; the Italians, Ginepro rosso, Red Juniper; is a native of Spain, Portugal, and the south of France. It grows ten or twelve feet high, and is branched all the way : the berries are of a redbrown colour, of the size of a hazel-nut, and very handsome, when in plenty. This was cultivated in England by Mr. Miller in 1739.

The Phœnician Juniper, Juniperus Phœnicia, also called the Phœnician Cedar, grows in the form of a pyramid: the leares on the upper branches are dark green; those of the lower have a greyish hue; the berries, when ripe, are of a pale yellow. This was introduced into England in 1683.

The Lycian Juniper, Juniperus Iycia, more commonly called the Lycian Cedar, is a native of the south of France, the Levant, and Siberia : it is very similar to the Savin, differing chiefly in the slenderness of the shoots, and in the leaves being less pointed, and not so clustered together. This was cultivated by Mr. Miller in 1759 .

Some think the Cedar mentioned by Virgil, in the second and third Georgics, was the Lycian Cedar, but it remains uncertain: whichever it was, he speaks of it as used for building, and as odorous :

\section{"dant utile lignum}

Narigiis pinos, domibus cedrumque cupressosque."

Georgic ii.

"The pine affords wood useful for ships, the cedar and the cypress, for houses." 
"Disce et olloratam stabulis accendere cedrum ;"

Georgic iii.

"Learn also to burn the odorous cedar in your folds."

MartYx's Translation.

Whatever the Cedar of Virgil may have been, it was certainly not the Cedar of Lebanon, and as certainly is understood to have been a species of Juniper. May translates this passage-

"But learn to burn within your sheltering rooms Sweet Juniper."

The smoke of Cedar was supposed by the Romans to drive away serpents.

Theophrastus describes a Cedar as growing in Syria, so large that three men could not encompass one: this is generally understood to mean the Phœnician Cedar, since he describes it as bearing a berry, not a cone*

The virtues of some species of the Juniper are very considerable, more particularly of the common Juniper : sugar may be obtained from the berries; the Swedes prepare a beer from them; and the Laplanders use a decoction of them as we use tea or cofiee. A wine is prepared from them also, called Juniper wine ; and they are in many cases found efficacious in medicinal preparations, as also are the young shoots, and the wood.

The Savin and the Lycian Juniper are also useful in medicine.

Martyn says that the gum-resin, called Olibanum, is supposed to be the incense formerly used by the ancients in their religious ceremonies, though not the substance known by that name in the shops. It is much em- 
ployed by the Roman Catholics in their chapels, for similar uses: when burned, it diffuses a very fragrant smell. This olibanum, or true frankincense, has been supposed to be the produce of the Lycian Juniper, but that plant does not afford any resin. The olibanum now sold in the shops is the produce of the Boswellia serrata, or Salai tree of India. The name of the gum seems to be a contraction of oleum Libani. The resin of the Norway spruce fir is sold under the name of common frankincense. Salmon says the olibanum sold a century ago was so entirely similar to the resin he had himself collected from the berry-bearing cedar, or Juniperus Phœnicea, that when mixed, they could not be separated by picking.

Dr. Clarke speaks of frankincense as the production of the Acacia Tera: "The Gum Arabic Acacia," says he, "or Mimosa Nilotica, also called the Acacia Vera, produces the frankincense. It grows in great abundance at Cairo: the gum is gathered in rast quantities from trees growing near the most northern bay of the Red Sea at the foot of Mount Sinai, and called Thus by the dealers in Egypt, from Thur and Thor, which is the name of a harbour in that bay; thereby being distinguished from the gum arabic, which comes from Suez. ' These gums,' says Hasselquist, ' differ in other particulars besides their localities; the first being limpid and colourless, the latter less pellucid, and of a brown, or dirty yellow colour. We purchased a considerable quantity of the white gum. The fragrant odour diffused in burning it is well known; but its operation as an enlivener of the spirits in persons of weak health, does not seem to have been much regarded. Perhaps the pleasing antidote it affords to the effects of foul air in crowded assembly 
rooms may possibly hereafter give it a place among the luxuries of Lonảon and Paris*.'"

Spenser alludes to the humble growth of the Juniper at the same time that he describes the lofty stature of the Cedar:

"From lowest Juniper, to Cedar tall."

Hall says that the Juniper Bush is almost everywhere to be met with about the roots of the Highland hills, and observes that it has one property of the fig tree, that it has always two crops of berries on it $\dagger$.

Captain Franklin tells us that the fruit of the Common Juniper is called by the Crees, Caw cazo quew meena, Crow-berry ${ }^{\ddagger}$.

It has been observed that the Swedes prepare a beer from the Juniper; a custom which appears common to Norway also. Brookes tells us, that while in Norway, he witnessed the peasants' method of brewing, which consists, says he, " merely in a simple infusion of barley and the young and tender shoots of the Juniper in warm water; which produces a weak, though not unpleasant, beverage §."

This author also informs us that a custom, which before the use of carpets was common in England, is still general in Norway,- -that of strewing the floor with Juniper: this has been common to many parts of Europe.

" On entering my little chamber, I was agreeably surprised to find every thing exceedingly neat and clean. The floor was strewed, as is the custom in Norway, with

* Clarke's Travels, vol iii. p. 51 .

+ Hall's Travels in Scotland, p. 433.

+ Journey to the Polar Shores.

$\S$ Brookes' Sweden and Norway, p. 131. 
tops of the Juniper, which diffused a delightful fragrance around, in the most agreeable manner inviting sleep*."

We learn both from this author and from Dr. Clarke, that the same custom prevails in Sweden.

In this country, the strewing of Juniper appears to have been confined to persons of rank or fortune, while persons of inferior consideration were content with rushes. The use of rushes for this purpose is noticed repeatedly in the works of Ben Jonson, and of Beaumont and Fletcher. Dryden, too, alludes to this custom in his version of Chaucer's Nun's Priest's Tale :

"Her parlour-window stuck with herbs around, Of savoury smell, and rushes strew'd the ground."

Fairfax gives the Juniper a bad character, in his translation of Tasso: the tree is not mentioned in this passage in the original :

"Sweet Juniper, whose shadow hurteth sore :"

Canto iii.

The poet has, nevertheless, great and ancient authority for what he says :

"Now let us rise, for hoarseness oft invades The singer's voice, who sings beneath the shades. From juniper unwholesome dews distil, That blast the sooty corn, the withering herbage kill." Dryden's Virgil, Ecl. $x$.

* Brookes' Sweden and Norway, p. 131. 


\section{LARCH TREE.}

\section{PINUS LARIX.}

CONIFERAE.

French, mélèze ; Italian, larice.

The Common or White Larch, Pinus Larix, is of quick growth, and will reach to the height of fifty feet. The leaves are long and narrow, growing in clusters from one point like tassels; and these clusters are placed alternately upon the branches; they are light green, and fall off in the autumn. In this respect, the Larch differs from all other trees of this genus, which are evergreens. The branches are slender, and droop at the end: the cones are about an inch long, shaped like an egg; their tops are sometimes tinged with bright purple, in others they are quite white; but the difference is merely accidental, and in no way affects the seeds they contain.

There are two varieties of this tree, one a native of America, the other of Siberia: the latter requires a colder climate; it is apt to die here in the summer, especially if planted in a dry soil. Of the American variety, the branches are more slender than those of the Common European Larch ; the leaves are narrower, more tender, glaucous, and the outer ones in each cluster shorter than the inner; whereas in the Common Larch, they are of equal length. The bark inclines to yellow in the American variety; in the common sort, it is an ash-coloured 
gray; the cones of the American, too, are not more than one-third the size of those of the European kind.

The Common Larch is a native of the South of Europe, and of Siberia : from Parkinson's Paradisus, it appears to have been cultivated here in 1629; but he speaks of it as "rare, and nursed up but with a few, and those only lovers of varieties." Evelyn murmurs at the neglect shown to a tree flourishing so well here: "A tree of good stature," says he, "not long since to be seen about Chelmsford in Essex, sufficiently reproaches our not cultivating so useful a material for many purposes where lasting and substantial timber is required. We read of beams of no less than an hundred and twenty feet in length made out of this goodly tree."

The Black Larch is a native of North America; it is of a darker colour than the Common Larch, and, comparatively with that, a stranger in this country: it does not grow so large as the European Larch, but it serves to increase variety, and will endure the climate boldly.

In Switzerland, where Larch trees abound, and they have little other wood, they build most of their houses, and make the chief part of their furniture, of its timber ; of which some is white, some red: the latter is most esteemed. Some suppose the redness to be occasioned by the quantity of turpentine contained in it, and to be peculiar to old trees. The boards, cut into shingles of a foot square, are often used to roof houses instead of tiles. When first laid they are very white, but in two or three years the resin being drawn out by exposure to the sun, fills up all the joints, and spreads over the surface; and, being hardened by the air, becomes a smooth, black, and shining varnish, impenetrable either by wind 
or rain. These roofs are, however, very combustible, and great damage has been done by fire in villages so built, on which account the people are obliged by law to build the houses at a certain given distance, one from the other.

Larch wood has been supposed by many persons to be impenetrable by fire; and a story is related of a castle besieged by Cæsar, which, from the liberal use of Larch, was, at least, very difficult to consume. Evelyn quotes from Cæsar the following words, which are sufficiently decisive :

"Et robusta larix, igni impenetrabile lignum."

"And the strong larch wood, which fire cannct penetrate."

There appears to be some truth in the notion that it will long resist fire, turning black long before it takes the flame. Several bridges were built of this timber by Tiberius, some think on this account. The forum of Augustus, at Rome, was built with it; and Vitruvius regretted that there was not a greater plenty of it to make joists. Evelyn says, it is so transparent, that when cabins made of the thin boards have lighted candles in them in the darkness of night, people at a distance would imagine them to be on fire. This writer also mentions a ship found some years since in the Numidian Sea, twelve fathoms under water, which was chiefly built of Larch and cypress, so hardened, as long to resist the fire or the sharpest tool. "Nor had any part of it perished," says he, "though it had lain upwards of fourteen hundred years submerged."

" Larch wood," says Dr. Anderson, " is possessed of so many valuable qualities, that to enumerate the whole would appear extravagant hyperbole. To say much in a 
few words, wherever strength and durability are required, however exposed to sun, wind, or water, the Larch will be found far superior to oak itself. But although it has been much used for ship-building, it has been found at Venice, that it is better to use it only for the lighter parts of the upper works, not where massy pieces of timber are required, on account of its weight. It takes an excellent polish, and is valuable to the turner. Among other uses, let it not be forgotten, that it has been the common material for painters' palettes, and that, before the use of canvas, it was the very substance upon which Raphael and other famous artists painted their celebrated pictures."

Mr. Martyn makes copious extracts from Dr. Anderson's account of the Larch, in his Essays on Agriculture, in which there is scarcely any purpose to which wood of any kind can be applied, for which he does not recommend Larch wood. With regard to its taking fire, he observes that where the masses are large, eren if a fire be placed on the bare wood, though it will be slowly corroded by it, yet, unless in particular circumstances, it cannot be made to flame so as to communicate it to other bodies.

Larch wood is used liberally in the buildings at Venice, " especially," says Erelyn, "about the paiaces in Piazza San Marco."

The Society for the Encouragement of Arts, Manufactures, and Commerce, in London, in the vear 1788, gave three gold medals, and a premium of $30 l$. for planting Larch, and making known the many useful purposes of its timber. They have offered both honorary and pecuniary rewards for its propagation. Of late years there have been made many plantations of Larch, and it 
is supposed that, were it cultivated in sufficient quantities, it would supersede the necessity of sending to Norway at an annual expense of many thousand pounds for timber.

In the year 1\%96, one nurseryman in Edinburgh raised above five millions of Larches, and the Duke of Athole for some years planted two hundred thousand annually.

Venice turpentine is obtained from the Larch by boring a hole with an augur about two feet above the ground, till it reaches half way to the centre of the tree; into this hole is inserted a small pipe, through which the turpentine flows into ressels placed for its reception. This process is continued from the end of May to the end of September, when the turpentine is pressed through a cloth to purify it. It is not thought worth while to begin to collect the turpentine from a tree until it has attained the size of a foot in diameter; and from that time, for forty or fifty years, if the tree continues in vigour, it will yield seven or eight pounds of turpentine annually. This turpentine is not now known in England, a composition made by dissolving yellow rosin in oil of turpentine being sold in its stead.

Old Larches produce a fungus, which is called Agaric; this is in some places used medicinally; and, with the roots of Gallium, for dying the hair of rein-deer red. It has a saponaceous quality, and women in Siberia often wash themselves and their linen with it.

The Siberian ermine-hunters carry about with them a kind of yeast or ferment for preparing the acid liquor which they call quass; this is often spoiled by the cold, in which case, they scrape off the albumen, or halfformed wood, between the wood and the bark of the Larch, which is very juicy and sweet, put it in water over the 
fire for an hour, mix it with rye-meal, bury the dough in the snow, and in twelve hours they have a ferment ready for use *.

There is also a gum and a manna obtained from the Larch. The manna is found in the south of France, and is there called Manna de Briançon : it is white, concrete and sweet, like fine new honey. It is rare, and met with only in little drops that adhere to the leaves, so that it would be difficult to collect a pound of it. This manna has been found in Russia also.

The gum is afforded only under certain circumstances; when the woods are on fire, which frequently happens in Russia, the Larches are sometimes burned next the side whence the fire came, to the height of several feet. If the wood happens to be scorched to the pith, the inner part exudes a dry reddish gum, which is called Orenburgh gum. It is used in medicine by the Russians, and the native mountaineers masticate it to fasten their teeth, as the ladies in the East use mastick. They also fasten their bows, \&c. with it.

The Larch is not much indebted to our poets for reputation, although its beauty is such as to have recommended to the frequent attention of Mrs. Radcliffe, who not only introduces it very frequently in her beautiful and romantic landscapes, but repeatedly refers to its use in wainscoting, \&c. both the White and the Black Larch. In the Mysteries of Udolpho, speaking of the Count de Villefort, she says, "He was himself going to strike upon the door, when he observed its singular beauty, and withheld the blow. It appeared on the first glance to be of ebony, so dark and close was its grain, 
and so high its polish; but it proved to be only of Larch wood of the growth of Provence, then famous for its forests of Larch. The beauty of its polished hue, and of its delicate carvings, determined the count to spare his door, and he returned to that leading from the back stair-case *."

It has been observed that the Larch is in abundance in some parts of Switzerland where there are few other trees; it is often found in places comparatively barren. Mrs. Radcliffe in the following passage gives a striking picture of one of these scenes :

" The scene of barrenness was here and there interrupted by the spreading branches of the Larch and cedar, which threw their gloom orer the cliff, or athwart the torrent that rolled in the vale. No living creature appeared, except the izard scrambling among the rocks, and often hanging upon points so dangerous that fancy shrunk from the riew of them + ."

The scene here described is among the Pyrenees, in the vicinity of some of the loveliest spots ever drawn by pen, or pencil, or even by the hand of Nature herself; so greatly does she delight to connect beauty with gloom. This union has been particularly noticed by a modern author :

" This hut was very old; that part of it which was built of stone was corered with moss, lichens, and wallflowers, whose beauty and scent appeared alien to the gloom around: But amidst desolation and horror, Nature loves to place the lorely and excellent, that man, viewing the scene, may not forget that she, the mother, dwells everywhere.$+ "$

* Vol. iii. p. 170. † Vol. i. p. 41. \$Valperga, vol. iii. p. 2. 
Ben Jonson speaks of the gum or the turpentine of the Larch, as being used in witcheraft, as Hemlock, Nightshade, \&c. :-A witch answers her companions-

"Yes, I have brought (to help your vows)

Horned-poppy, cypress-boughs,

The fig-tree wild, that grows on tombs,

And juice that from the larch-tree comes,

The basilisk's blood, and the viper's skin:

And now, our orgies let's begin *."

Lucan includes the "gummy Larch," among the articles burned to drive away serpents $\dagger$.

Larch has of late been applied to the purpose of shipbuilding, and with success. Some think that it will, in time, supersede the Norway fir. In proportion as this timber is found useful, it must become profitable, and consequently plantations of Larch will be likely still to spread; to the great annoyance, as it appears, of Mr. Wordsworth. He seems to have a strange dislike to this fine tree. "Larch and fir plantations," says he, "have been spread, not merely with a view to profit, but in many instances for the sake of ornament. To those who plant for profit, and are thrusting every other tree out of the way to make room for their favourite, the Larch, I would utter first a regret that they should have selected these lovely vales for their vegetable manufactory, when there is so much barren and irreclaimable land in the neighbouring moors, and in other parts of the island, which might have been had for this purpose at a far cheaper rate. And I would also beg leave to represent to them that they ought not to be carried away by flattering promises from the speedy growth of this tree ; be-

* Masque of Queens.

+ See Rowe's Lucan, book ix. 
cause, in rich soils and sheltered situations, the wood, though it thrives fast, is full of sap, and of little value ; and is, likewise, very subject to ravage from the attacks of insects, and from blight *."

Again, he says, "It must be acknowledged that the Larch, till it has outgrown the size of a shrub, shows, when looked at singly, some elegance in form and appearance, especially in spring, decorated, as it then is, by the pink tassels of its blossoms; but, as a tree, it is less than any other pleasing; its branches (for boughs it has none), have no variety in the youth of the tree, and little dignity even when it attains its full growth ; leaves it cannot be said to have, consequently it affords neither shade nor shelter. In spring, the Larch becomes green long before the native trees, and its green is so peculiar and vivid, that finding nothing to harmonize with it, whereever it comes forth, a disagreeable speck is produced. In summer, when all other trees are in their pride, it is of a dingy lifeless hue; in autumn, of a spiritless unvaried yellow, and in winter it is still more lamentably distinguished from every other deciduous tree of the forest, for they seem only to sleep, but the Larch appears absolutely dead †."

He still goes on for another page to make objections against the unhappy Larch tree, which is, indeed, to be pitied in having, for its enemy, a pen so powerful.

* Wordsworth's Description of the Scenery of the Lakes, p. 86. † Ibid.p. 93. 


\section{LAUREL.}

PRUNUS.

The word Prunus is supposed to be of Asiatic origin.-French, laurier-cerise ; Italian, lauro-regio.

The Laurel, commonly so called, Prunus lauro-cerasus, is too well known to need description: it is included in the same genus with the cherry-tree, and, in Johnson's edition of Gerarde's Herbal, is called the Cherry-bay, the translation of its present specific name. Johnson says, "it was sent to Clusius from Constantinople by the name of Trabison Curmasi, or the Date or Trebisond; but it hath no affinity with the date. Clusius, and most since, call it fitly Lauro-cerasus, or Cerasus folio laurino. It is now got into many of our choice English gardens, where it is well respected for the beauty of the leaves, and their lasting or continual greenness. The fruit is good to be eaten, of a sweet and pleasant taste, with a stone in it like a cherry."

This tree is a native of the Levant, Caucasus, the mountains of Persia, and the Crimea. Clusius received it in the year 15\%6, from David Ungnad, then ambassador of Germany at Constantinople, with some other rare trees and shrubs, all of which are said to have perished by the severity of the weather, and the carelessness of those who brought them, with the exception of this Laurel and a horse-chestnut. Clusius says, indeed, that the Laurel was almost dead; he put it into a stove 
exactly as it arrived, in the same tub and earth; in the April following he took it out, cut off all the withered branches, and set it in a shady place; in the autumn it began to shoot from the root; he then removed the living: part into another tub, and took great care of it : when it was sufficiently advanced, he laid down the branches, which took root; and he distributed his plants among his friends and men of eminence. Clusius's plant died without flowering; but one of those which he gave away, blossomed in the year 1583 .

Parkinson, in his Paradisus, published in 1629, speaks of it by the name of Bay-Cherry; saying he had a plant of it given him by Mr. James Cole, a merchant of London, then lately deceased, in whose garden at Highgate it was growing. It had flowered several times, and also borne ripe fruit. He describes Mr. Cole's as a fair tree, which he defended from the bitterness of the weather by throwing a blanket cver the top of it every winter. It is curious to picture to oneself these careful naturalists tenderly nursing and watching over the fate of a plant, which now is common, not only to every gentleman's garden and shrubbery, but is seen coasting every dusty garden in the suburbs. Had the plant sent to Clusius been taken less care of, and died, the tree might have been many years longer a stranger in England, and we might still have been wrapping it in blankets.

It is said that powdered Laurel-leaves will excite sneezing ; these leaves are poisonous, and have in several instances proved fatal to the human race; to brute animals they are almost instantaneously mortal : yet they have been used both in medicinal and culinary preparations.

The Portugal Laurel, Prumus Lusitanica, is a beautiful 
evergreen, with large, glossy, pointed leaves, and blossoms very similar to those of the common Laurel. It blossoms in June, and the berries ripen in October. This shrub was brought to England from Portugal; but whether a native of that, or a plant which had been introduced from some other country, is not certain. The Portuguese call it Azoureiro; the French, Azarero; the Italians, Pruno Portoghese. By these names it appears, that to whatever country it originally owed its birth, it went to France and Italy, as it came to us,-from Portugal.

The Kew Catalogue describes it as a native of Portugal and Madeira. It was cultivated in England in 1722. 


\section{LAURUSTINUS.}

\section{VIBURNUM TINUS.}

Viburnum, from viere, to bind; some of the shrubs of this genus affording twigs fit for bands. French, laurier-thym; Italian, lauro tino; English, laurustinus, laurustine; which names signify little laurel; so called by old authors, who considered it as a smaller species of the bay-tree. Gerarde and Parkinson call it the Wild Bay-tree.

There are several varieties of the Laurustinus; the Common, the Hairy, the Upright, and the Shining-leaved : the latter is by far the most ornamental; it grows higher and stronger; the bark is smoother, the leaves larger, of a thicker consistence, and of a finer green than the othe varieties. The flowers also are larger, and in larger clusters; but this is considered the least hardy. It is a native of Portugal and Spain, Mount Atlas, and Algiers.

The Hairy Laurustinus is a native of Spain, Portugal, and Nice: this is the most hardy of all.

The leaves of the Upright Laurustinus are hairy underneath, and those of the common sort are hairy at the edges: this last variety is an Italian. It was cultivated here in 1556 .

"We scarcely recollect a plant," says Mr. Curtis, "whose blossoms are so hardy as those of the Laurustinus; they brave the inclemency of our winters, and are not destroyed but in very severe seasons. The smoke of London is highly detrimental to its growth : it thrives best in a dry soil, and sheltered situation." 
The Laurustinus is one of the tasteful trees that gathered around Orpheus to listen to his lyre :

"There stood a mountain on whose towering head, Wide, void of shade, a grassy meadow spread. Here, while harmonious as his radiant sire, Orpheus reclined, and struck his golden lyre, Trees, gathering round, his godlike power bespoke; The poplar tall, the wide-expanding oak, Join the soft teil, and first the meadow reach; The brittle hazel next, the mountain beech; The wild-ash, hewn in spears when clarions stir Assembled chiefs to war; the knotless fir : The lotos red, in marshy lowlands found; The tree of heavenly Jove, with acorns crowned; The plant whose smiles Apollo sought in vain; The mottled maple, and the genial plane; The tamarisk; the willow, whose green locks Trail o'er the stream; the ever-verdant box; The flowery myrtle; the green-berried tine; The tendrill'd ivy, and the branching vine; The sable pitch-tree with expanded root; The slender cherry, red with nodding fruit : The lofty elm with creeping vines o'erspread; The bending palm that graces victory's head; And that rough tree whose branching foliage nods, Loved by the mighty mother of the gods, Since youthful Attis, to her fondness blind, slept in its core, and hardened in its rind.

Such were the trees that own'd the magic sound." DR. ORGER's Orid, book x.

Few of our poets have noticed this beautiful shrub: it is mentioned in Dodsley's Agriculture as finely contrasting with the laburnum and the daphne mezercon: 
" Now lost

Amidst a glooming wilderness of shrubs The golden orange, arbute evergreen, The early blooming almond, feathery pine, Fair opulus *, to spring, to antumn dear, And the sweet shades of varying verdure, caught From soft acacia's gently waving branch, Heedless he wanders: while the grateful scents Of sweetbriar, roses, honeysuckles wild, Regale the smell; and to the enchanted eye Mezereon's purple, laurustinus' white, And pale laburnum's pendent flowers display Their different beauties."

This shrub is so absolute in its love of the country, that it will not live in London, nor thrive near it.

* Guelder Rose. 


\section{LIME TREE.}

TILIA.

French, tilleul ; Italian, tiglio, tiglia ; English, lime, or linden, (which is the German name also), and in Lincolnshire, bast, because ropes are made from the bark. Gerarde adds line tree.

The Lime, Tilia Europcea, is a tall upright tree, with smooth spreading branches, thickly clothed with alternate heart-shaped, smooth, serrate leaves, pointed at the ends, of a very cheerful green. The flowers are of a yellowish colour, delightfully fragrant, especially at night, growing in clusters of four or five together, and blowing in July.

The Lime is a native of most parts of Europe, and of Japan. The small-leaved variety grows wild in many parts of England, in woods, and on grassy declivities. The common, and other varieties, are more commonly seen cultivated in hedges, avenues, parks, \&c. and before houses. It will bear the smoke of London tolerably well.

The Lime-trees in St. James's Park are said to have been planted at the suggesticn of Mr. Evelyn ; probably with a view to the improvement of the air, which they have been thought to effect.

The Dutch plant Limes in abundance by their canals; and during July and August the whole country is perfumed with their blossoms, overcoming the unpleasant effluvia arising from the stagnant water at that season. Miller complains that it has been much neglected, because it sheds its leaves early in the autumn, and does not put them forth till late in the spring. They begin 
to open about the twelfth of April, and are all out by the eighteenth.

Evelyn, too, complains of the "shameful negligence of our countrymen in not being better provided of a tree so choice and universally acceptable." For in his time they were imported from Holland and Flanders at a great expense, and that, too, "whilst our own woods spontaneously produce them, and though of a somewhat smaller leaf, yet altogether as good, apt to be civilised, and made more florid."

It is indeed a most beautiful tree; it grows in a handsome form, and to a large size; the foliage is elegant, and of a fine verdure; its ample leaves and spreading branches afford an admirable shade, and the fragrance of its blossoms is delightful :

"Clear was the song from Philomel's far bower;

Grateful the incense from the lime tree flower."

Moreover, it will resist wind and storm.

KeAts.

Mr. Martyn remarks, that it was highly esteemed by the Romans for its shade, and numerous uses, and quotes the following line from Pliny in praise of it :

"Tiliæ ad mille usus petendæ."

"Lime trees for a thousand uses sought."

"The flowers," says Dr. Hunter, " begin to open about the fifteenth of May, and are in full blow about the thirteenth of July, when they appear of a white colour, and have a very fragrant smell. These are very grateful to bees; for which reason Virgil, in his beautiful description of the industrious Corycian, places the Lime and the pine in the neighbourhood of his hives:"

" Ergo apibus fetis idem atque examine multo

Primus abundare, et spumantia cogere pressis

Mella favis ; illi tiliæ, atque uberrima pinus."

Georgic iv. 
" $\mathrm{He}$, therefore, was the first to abound with pregnant bees, and plentiful swarms, and to squeeze the frothing honey from the combs : he had limes and plenty of pines."

Martyn's Translation.

Martyn observes, in a note upon this passage, that Columella affurms that the Lime is hurtful to bees.

Evel-rn praises the Lime as being "6 the most proper and beautiful for walks, as producing an upright body, smooth and even bark, ample leaf, sveet blossom, the delight of bees, and a goodly shade at the distance of eighteen or twenty-five feet."

There is certainly no contradiction in what these authors say of the Lime being agreeable to bees, and Columella's assertion that it is injurious to them : but it is strange that Virgil should either not know, or that he should overlook such a circumstance, since he is very particular in warning the husbandman against such plants as will hurt the bees; and although the Lime is not intimately connected with those busy insects in the passage just quoted, yet a little further on he speaks of it expressly as affording them food:

"—_ pascuntur et arbuta passim,

Et glaucas salices, casiamque, crocumque rubentem, Et pinguem tiliam, et ferrugineos hyacinthos."

"They feed also at large on arbutes, hoary willows, cassia, and glowing saffron, and fat limes and deep-coloured hyacinths."

The Russian peasants are said to suspend their beehives in the woods purposely that the bees may have the early blossom of the Lime, which is thought to produce very fine honey. The Lime grows in Russia more abundantly than any other tree, with the exception of the birch; and what the birch is to the Swedish peasant, the Lime is to the peasant of Russia. The thick bark is made into baskets for carriages and sledges, into boxes 
and trunks; and helps to roof their cottages. Of the inner bark are made mats, many of which they export ; the rind of the young shoots they braid into shoes. "s The wood is sawn into boards, wrought up into canoes, and burned into pot-ashes, and from the blossom of the Linden tree the bees suck an excellent nourishment *."

Evelyn says, that in a rich loamy soil, which the Lime affects, "its growth will be most incredible for speed and spreading." Of the several varieties, the Red-twigged is the most desirable, from the very circumstance which gives it the name; the red twigs finely contrasting with the green foliage.

There are several Lime trees upon record remarkable for their magnitude: it will suffice to mention a few of the most considerable. Evelyn speaks of one in Switzerland forming a bower with its branches, capable of containing three hundred men sitting at ease. It has a fountain, set about with many tables, formed only of the boughs, to which they ascend by steps, all kept so accurately, and so very thick, that the sun never looks into it. "But this," continues he, "is nothing to that prodigious Lime of Neustadt, in the duchy of Wirtemberg, so famous for its monstrosity, that even the city itself receives a denomination from it, being called by the Germans ' Neustadt ander grossen Linden,'- Neustadt by the great Lime tree.' The circumference of the trunk is twenty-seven feet four fingers."

He mentions a third, the account of which he received from Sir Thomas Brown of Norwich, and gives in his own words. We will hope he speaks from his own knowledge, since whatever he heard, his "active faith" would credit. 
66 At Depeham, in Norfolk, grows an extraordinary Lime tree, the compass of which, in the least part of the body, is eight yards and a half, and about the roots, near the earth, it measures sixteen yards. This surmounts the famous Lime of Zurich in Switzerland, and uncertain it is whether in any Lime-walk abroad it be considerably exceeded."

This tree was ninety feet high.

The wood of the Lime tree is turned into light bowls, and dishes, and boxes for the apothecaries; but its chief use is for carving :

"Their beauteous veins the yew

And phillyrea lend, to surface o'er

The cabinet. Smooth linden best obeys

The carver's chisel; best his curious work

Displays in all its nicest touches."

Dodsley's Agriculture.

66 Many of Gibbons's beautiful works in Lime tree are dispersed about this country," says Martyn, "6 in the churches and palaces: as in the choir of St. Paul's; the Duke of Devonshire's at Chatsworth; Trinity College library, at Cambridge, \&c." Evelyn, speaking of these works of Gibbons, says, "Having had the honour (for so I account it) to be the first who recommended this great artist to his Majesty Charles the Second: I mention it on this occasion with much satisfaction."

"With the twigs of the Lime," observes this delightful author, "they make baskets and cradles, and of the smoother side of the bark, tablets for writing; for the ancient Philyra is but our Tilia, of which Munting affirms he saw a book made of the inward bark, written about a thousand years since. Such another was brought to the Count of St. Amant, governor of Arras, 1662, for which there were given eight thousand ducats by the 
emperor. It contained a work of Cicero, De Ordinanda Republica, et de Inveniendis Orationum Exordiis; a piece inestimable, but never published, and now in the library at Vienna, after it had formerly been the greatest rarity in that of the late Cardinal Mazarine. Other papyraceous trees are mentioned by West Indian travellers, especially in Hispaniola, Java, \&c. whose inward bark not only exceeds our largest paper for breadth and length, and may be written on both sides, but is comparable to our best vellum. Bellonius says that the Grecians made bottles of the Tilia, which they finely resined withinside." Again, speaking of the numbers of Limes planted by the Dutch, he breaks forth in a rapturous manner,_- Is there a more ravishing or delightful object than to behold some entire streets and whole towns planted with these trees, in even lines before their doors, so as they even seem like cities in a wood? This is extremely fresh, of admirable effect against the epilepsy, for which the delicately scented blossoms are held prevalent, and skreen the houses from wind, rain, and dust; than which there can be nothing more desirable where streets are much frequented*."

It has been observed that the Lime is called Bast in Lincolnshire, because ropes are made of the bark ; mats also are made of it, which are used by gardeners, and are called Bast in the north of Europe. Great numbers of them are made in Russia, and exported to other countries. The sap of the Lime, inspissated, affords a quantity of sugar.

The garlands of flowers with which the ancients crowned themselves in their convivial entertainments, were artfully bound together with slips of the inner rind of the Lime tree.

* Evelyn's Sylva. 
"Ebrius incinctis philyra conviva capillis Saltat, et imprudens utitur arte meri."

Ovid. Fast.

"A cup too much the boon companion takes, And reeling in the dance, his linden riband shakes."

" Displicent nexæ philyra coronæ." Horace, Ode xxxviii. book i.

"Ribands from the linden tree Give a wreath no charms for me*."

The character of the Lime the most frequently noticed by poets, is its smoothness: Virgil says, - "Tiliæ læves :"-" Smooth Limes." Cowper alludes to this quality in the following passage, in which he describes a beautiful character of woody scenery which has not often been touched upon :

“6 Here the gray smooth trunks

Of ash, or lime, or beech, distinctly shine, Within the twilight of their distant shades; There, lost behind a rising ground, the wood Seems sunk, and shortened to its topmost boughs."

Task, book i.

The same circumstance is noticed in the Story of Rimini, with the addition of a bright sunshine :

" Places of nestling green for poets made, Where, when the sunshine struck a yellow shade, The slender trunks to inward-peeping sight, Throng'd in dark pillars up the gold green light."

Leigh Huxt.

* This is Horace speaking. He is telling his servant not to make ostentatious preparations for the wine he is going to drink under a bower, nor to add any thing to the simple crown of myrtle for his head. 
This poet, who was the first, and has hitherto been the only mortal, who has been honoured with the sight of the Nepheliads in person, informs us that they love

"__ a leafy nook and lone,

Where the bark on the small treen

Is with moisture always green;

And lime tree bowers, and grass-edged lanes

With little ponds that hold the rains,

Where the nice-eyed wagtails glance,

Sipping 'twixt their jerking dance."

Nymphs, part ii.

According to Rapin, (whom on this account we must quote, notwithstanding the poverty of the English version,) Baucis and Philemon were transformed to Lime trees :

"The mounting limes will all their care requite,

Who take in shady walks a true delight;

While these you plant, Philemon call to mind, In love and duty with his Baucis join'd, A good old pair whom poverty had tried, Nor could their vows and nuptial faith divide; Their humble cot with sweet content was blest, And each benighted stranger was their guest : When Jove unknown they kindly entertained, This boon the hospitable pair obtained,

Laden with years, and weak through length of time, That they should each become a verdant lime."

Cowley praises the Lime tree very highly, in his poem on trees.

Sannazaro calls it "la incorrutibile Tiglia," the incorruptible Lime; for, says the editor, "non sente mai corrottione di sorte alcuna." "It never feels corruption of any sort*."

* Arcadia di M. I Sannazaro, prosa prima. 


\section{LIQUIDAMBER TREE.}

\section{LIQUIDAMBAR.}

This tree was so named by the Spaniards in America, from the liquid gum which it distils. It is familiarly called sweet-gum, and was formerly called liquid storax-tree.-French, copalme, liquidambar; Italian, liquidambra.

THE trunk of the Liquidambar styraciflua is commonly two feet in diameter at full growth, straight, and bare of branches to the height of fifteen feet; from thence the branches spread and rise in a conic form, to the height of forty feet or more from the ground. The leaves are shaped somewhat like those of the lesser maple, but are of a darker green, and glossy on their upper surface : a sweet and glutinous substance distils through their pores in warm weather, which renders them clammy to the touch. In February, before the leaves are formed, the blossoms begin to break forth from the tops of the branches, into spikes of pale red, or deep saffion-coloured globular flowers, which swell gradually, still retaining their round form, to the full maturity of the seed-vessels, which are thickset with pointed hollow protuberances: each cell contains a seed winged at one end, beside many small grains, distinct from the seed.

The wood of this tree is used in wainscoting, \&c. The grain is fine, and sometimes beautifully variegated; but is apt to shrink if not well seasoned; and to season it well is an operation of eight or ten years. From be- 
tween the wood and the bark issues a fragrant gum, which trickles from wounds made in the trees, and congeals in the heat of the sun into transparent drops; this the Indians use as a preservative to their teeth. With the bark they cover their huts.

This tree is a native of North America, in low clayey ground: it was cultivated in the garden of Compton, Bishop of London, by his gardener, George London, in 1688, and bears the severest cold of our climate without injury. 


\section{MAGNOLIA.}

Named Magnolia by Plumier, in honour of Pierre Magnol, professor of medicine, prefect of the Botanic Garden at Montpelier, and author of several botanical works. Miller calls the laurelleaved magnolia, sweet-flowering bay: the gardeners give it the appellation of tulip-tree; a name also common to the Liriodendron tulipifera.-French, magnolier; Italian, magnolia.

The Magnolias are trees; chiefly American, and none European. Their leaves are large ; their flowers axillary, very large and sweet-scented.

The Great Laurel-leaved Magnolia, Magnolia grandiflora, in the southern provinces of North America, rises with a straight trunk of two feet or more in diameter, to the height of seventy or eighty feet, or yet higher, dividing into many spreading branches that form a large regular head. The leaves are nine or ten inches long, and three broad in the middle, of a thick consistence, resembling those of the common laurel, but much larger ; they are of a lucid green on the upper surface, and often of a russet colour beneath : they continue green all the year, falling off only as new ones are produced. The flowers are large, composed of eight or ten petals, narrow at their base, but broad, rounded, and a little waved at their extremities : they spread open very wide, are of a pure white, and have an agreeable odour.

In its native country, this tree begins to blossom in May, and continues in flower for a long time, so that the woods are perfumed with it the greater part of the 
summer; but here it seldom begins to flower till the middle or end of Jume, and does not remain long in bloom. English summers are not warm enough to bring the fruit to perfection.

This fine tree is a native of Carolina and Florida, and, in common with many of the trees and plants of that country, is impatient of cold here, and difficult to keep in perfection either abroad or in the green-house. Its beauty would render it one of the greatest ornaments of our plantations. It is most liable to suffer from the early frosts of autumn, the extremities of the young shoots being then tender: this is the most tender of all the species, from the circumstance of its retaining its leaves. Miller says there were a great many young plants in England, which were destroyed by the severe winter of 1739-40: and that he had one himself, which he supposed to be dead, a pretty large one; after midsummer, he cut it down to the root, and was surprised to see it shoot up again the next year.

The Swamp Magnolia, Magnolia glauca, grows with a slender stem, about fifteen or sixteen feet high; the leaves resemble those of the bay, but that they are hoary on the under side. The flowers are composed of six concave petals, white and sweet-scented; they blow in May and June. In North America, there is a succession of flowers for two months or more; but in this country, there are seldom more than twelve or fourteen on a tree, and those are of short duration. The fruit is of a conical shape, something more than an inch long, and three quarters of an inch in diameter; it is first green, then red, and when ripe, of a brown colour.

This tree sheds its leaves early in November : the young trees will sometimes retain the leaves till new ones form; 
and this circumstance has induced some persons to divide them into two species, one deciduous, and one evergreen.

In America, it is known by the names of White Laurel, Swamp Sassafras, and Beaver tree: it has the last name from that animal being caught by means of the root, which it eats as a great dainty.

Kalm says that he has seldom found this tree north of Pennsylvania, where it begins to flower at the end of May. "These trees may then be discovered," says he, " by the scent of the blossoms, at the distance of three quarters of a mile, if the wind be favourable. It is beyond description pleasant to travel in the woods at that season, especially in the evening. 'They retain their flowers three weeks, and even longer : the berries also look very handsome when they are ripe, being of a rich red colour, and hanging in bunches on slender threads. They cure coughs and other pectoral diseases by putting these berries into brandy, and giving a draught of the liquor every morning. It is even said to have salutary effects in consumptions. For a cold, they commonly boil the branches in water ; the wood is made use of for joiners' planes *."

Dillenius says, the flowers of this tree never open in a morning; and that their scent resembles that of the lily of the valley with a mixture of aromatic.

The Blue Magnolia, Magnolia acuminata, will grow thirty feet high, with a trunk eighteen inches or more in diameter : the leaves are nearly eight inches long, and five broad; the flowers are composed of twelve blue petals; they blow early in the spring, and are succeeded by a fruit about three inches long, somewhat resembling a

* See Martyn's edition of Miller's Gardener's Dictionary. 
small cucumber; whence the inhabitants of North America call it the cucumber tree. The wood is fine-grained, and orange-coloured. This tree is not very common in the inhabited parts of America. It was cultivated here by Mr. P. Collinson in $1 \% 36$.

The Umbrella Magnolia, or Umbrella tree, Magnolia tripetala, grows from sixteen to twenty feet high, the leaves are remarkably large; from twelve to sixteen inches in length, and five or six in breadth, narrowing to a point at each end ; they are placed in a circular manner at the ends of the branches, somewhat like an umbrella; whence its name. The flowers are composed of ten, eleven, or twelve large oblong white petals; the outer ones hanging down : the wood is soft and spongy. The leaves drop off early in winter. This tree is frequent in Carolina, and is also found in Virginia, and in some parts of Pennsylvania. It was cultivated here in 1752.

Thunberg says that almost every house in Japan has a little piece of ground behind it, adorned with shrubs and flowers; and that he constantly saw the Magnolia among them.

The Magnolia is not sufficiently well known in this country to be celebrated as its beauty deserves. Wordsworth says, speaking of a traveller-

" He spoke of plants divine and strange That every hour their blossoms change, Ten thousand lovely hues! With budding, fading, faded flowers : They stand the wonder of the bowers

From morn to evening dews.

"He told of the magnolia, spread High as a cloud, high overhear!

The eypress and her spire; 
Of flowers, that with one scirlet gleam

Cover a hundred leagues, and seem

To set the hills on fire."

$$
\text { Vol. i. p. } 151 .
$$

Tighe, in his poem entitled the Rose, exalting the beauty of that floral sovereign, says

" Less prized, Gardenia drops her lucid bells, And rich magnolias close their purple robes." 


\section{MAPLE 'T'REE。}

ACER.

The etymology of the botanical name is uncertain. French, erable; Italian, acero, stucchio: the Italian maple, loppo.

THis genus consists of trees, most of which yield a saccharine juice from the trunk, branches, and leaves. The leaves are either palmate, or are divided into three or five lobes: the flowers grow in clusters, and are of a yellowish green colour, with exception of one species, of which the blossom is scarlet.

The Tartarian Maple, Acer Tataricum, differs from most of the genus in the form of its leaves, which are something similar to those of the hornbeam, having scarcely any apparent lobes. It is a native of the south of Russia; it grows about twenty feet high. The wood is white, veined with brown. This Maple was cultivated by Mr. P. Miller in $1 \% 59$.

The Scarlet-flowering Maple, Acer rubrum, is cultivated in this country for the sake of the flowers, which blow early in the spring. In Pennsylvania, where it grows in the swamps and marshes, the natives use it for almost every kind of wood-work: with the bark they dye a dark blue, and make a good ink. The Canadians tap the tree for the juice, of which they make sugar and treacle. This tree was cultivated by J. Tradescant, jun. in 1656. There are two varieties in the nurseries; 
the Virginian Scarlet-flowering, and Sir Charles Wager's Scarlet-flowering Maple. The latter produces its blossoms in larger clusters than the common kind, and is therefore more esteemed. There is a variety of this tree, called the Curled Maple: the wood being marbled, utensils made of this are considered more valuable than those of any other wood.

The American Sugar Maple, Acer saccharinum, will grow to the height of forty feet: the leaves are deeply cut, and glaucous on the under side; the flowers have no petals, but are white, and very pretty; coming out before the leaves.

From this Maple the inhabitants of North America make large quantities of sugar, by tapping the trees early in spring, and boiling the juice. It is supposed that they obtain sugar from other species of Maple also, but this yields the most juice. In its native country, large tracts of land are covered with it; and it not only yields sugar plentifully, but of a quality equal to the best prepared from the cane. The drawing off and boiling the juice may be done by women and girls; and when the tree is skilfully tapped, it will last many years. It has been said that the natives not only have enough sugar for their own consumption, but export it also. The tree is not injured by tapping; but, on the contrary, yields the more juice in proportion to the number of times it has been tapped; and a tree has been known to flourish after forty-two annual operations.

In a good season, a tree of an ordinary size yields from twenty to thirty gallons of syrup, from which are made five or six pounds of sugar. The trees that grow in exposed situations are said to yield more sap than others : a farmer of Pennsylvania, having planted a number of these trees in his meadow, obtained, twenty years 
afterwards, a pound of sugar from every three gallons of sap.

The season for tapping the trees is in February, March, and April ; from a pint to five gallons of syrup may be obtained from one tree in a day : but on the 14th of April 1789, twenty-three gallons were obtained from a single tree.

An auger is introduced three quarters of an inch deep in an ascending direction, and afterwards gradually deepened to the extent of two inches. A pipe, which is generally made of the sumach, or elder-wood, is then put into the wound, about half an inch deep, projecting from three to twelve inches. The tree is first tapped on the south side, afterwards on the north: the sap flows, from four to six weeks, according to the temperature of the weather; three or four gallon troughs are placed under the spout to receive it: this is carried every day to a large receiver, from which, after being strained, it is conveyed to the boiler.

The sugar is improved by straining the sap through a cloth; when it is about half boiled, a small lump of butter or hog's lard is put in, to prevent its boiling over, and lime, eggs, or new milk, are mixed with the sap to clarify it. The latter is reckoned the best, but clear sugar may be made without either of them. When sufficiently boiled, it is clayed and refined much in the same manner with the cane-sugar. The sap should never be kept longer than twenty-four hours before it is boiled; and that boiled in a copper vessel will be of a fairer colour than when boiled in an iron one.

For many years a great many private families in Pennsylvania have supplied themselves with this sugar in plenty. Many have made from 200 to $400 \mathrm{lbs}$. in a year. 
One man sold $600 \mathrm{lbs}$. made in one season, entirely with his own hands; another, without any assistance, and besides attending to the other business of his farm, made 640 lbs. in four weeks.

The Indians in Canada have made Maple sugar time out of mind, and obtained a pound from every gallon of sap. The French began to refine it in that country towards the close of the seventeenth century.

During the summer months, and early part of autumn, the tree yields a thinner sap, not fit for sugar; this affords a pleasant beverage in harvest-time, and is sometimes used instead of rum, by farmers in Connecticut, whose ancestors have left them here and there a Maple tree in the midst of a field, probably intended as a shade for their cattle. Mr. Bruce describes a beverage of the same kind, prepared by the inhabitants of Egypt, by infusing the sugar-cane in water; which he declares to be the most refreshing drink in the world.

Baron la Houtan gives the following account of the sap of the Sugar Maple, when used as a drink : "T 'The tree yields a sap, which has a much pleasanter taste than the best lemonade or cherry-water, and makes the wholesomest drink in the world. This liquor is drawn by cutting the tree two inches deep in the wood; the cut being made sloping to the length of ten or twelve inches; at the lower end of this gash a knife is thrust into the tree slopingly, so that the water runs along the cut, as through a gutter, and falls upon the knife, under which a vessel is placed to receive it. Some trees will yield five or six bottles of this water in a day; and some inhabitants of Canada might, in one day, draw twenty hogsheads, if they would thus cut all the Maple-trees 
in their plantations. The gash does no harm to the tree*."

The Pennsylvanian Maple, Acer Pennsylvanicum, seldom exceeds fifteen feet in height: the stem is slender, covered with a whitish bark, and sending forth several branches; the leaves are nine inches long, and nearly as wide. This species was introduced here in 1755 , by Messrs. Kennedy and Lee.

The Ash-leaved Maple, Acer negundo, is a tree of quick growth; and in Virginia and Carolina, where its growth is spontaneous, is one of the largest of the Maples: the leaves are of a pale green, not lobed., This tree is apt to split if much exposed to keen winds: the wood is soft and brittle, but is used for the same purposes as that of the Norway Maple. It was cultivated in the garden of the Bishop of London, at Fulham, in 1688.

The Italian Maple, Acer opalus, is a common tree in Italy, and one of the loftiest in that country; it is esteemed for the shade afforded by its large leaves, and frequently planted near habitations, and by the sides of the roads. It was cultivated by Mr. Miller in 1752.

The Montpelier Maple, Acer Monspessulanum, grows about twenty feet high; the leaves are of a shining green, and preserve their freshness very late in the autumn. Mr. Miller had this in his garden in the year 1739 .

The Cretan Maple, Acer Creticum, is very much like the last-mentioned, and is about the same sized tree: when young the leaves are ovate, but afterwards they take the shape of the ivy-leaf before that becomes ovate. When the trees are in a sheltered situation, the leaves continue green the greater part of the year. It is from

- See Martyn's edition of Miller's Gardening Dictionary. 
the Levant. Mr. Miller cultivated it in 1752. The tree which he describes as an evergreen Maple is supposed to be a variety of this.

The Norway Maple, Acer platanoides, grows to a large size; the leaves are of a shining green, about the size of those of the Sycamore, and it sometimes makes a handsomer appearance than that tree, owing to a sharp juice with which it abounds; which, being disliked by insects, prevents their eating or destroying the leaves as they do the sycamore leaves. The flowers, which are of a fine yellow colour, add to the beauty of the tree in spring; in summer it forms an admirable shade, and in the autumn the leaves, then of a golden yellow, make a beautiful and conspicuous figure among the rich variety of hues peculiar to that season.

Linnæus recommends this tree as yielding a sap from which sugar may be made, and as affording a white, smooth wood for gun stocks, \&c. It is a quick grower. There is a variety with variegated leaves; but the principal variety is that which is called the Cut-leaved Maple, of which the leaves are deeply jagged.

The Norway Maple was cultivated in England in 1724. In France this tree is called Platane, or Faux Sycomore; as they call the sycamore Sycomore, or Faux Platane.

The Common Maple, Acer campestre, though it does not become a large tree, "yet," says Mr. Martyn, " it should not have been degraded by Linnæus to a shrub." Evelyn says, that by shredding up the boughs to a head, he has caused it to shoot to a wonderful height in a little time. This Maple is chiefly seen in hedge-rows and coppices.

The wood of this tree was highly valued by the an- 
cients, and some of their writers have much praised it: Pliny in particular commends Maples in general, and extols some for the remarkable fineness of the grain.

"In former times," says Evelyn, "so mad were people in searching for the bruscum* of this tree, which often formed the exact representation of birds, beasts, \&c. that they spared no expense in procuring it. The timber is used for musical instruments, inlaying, \&c. and is reckoned superior to most woods for turnery ware. The flower-buds begin to open about the 6th of April, and are in full blow by the 11th of May; the leaves are out about the 18th of April."

Pliny says, "The Maple, for the elegancy and firmness of the wood, is next to the very citron itself $\%$. There are several kinds of it, especially the White, which is wonderfully beautiful; this is called the French Maple, and grows in that part of Italy that is on the other side of the Po beyond the Alps; the other has a curled grain, so curiously spotted, that from a near resemblance, it was usually called the Peacock's-tail."

Again, Pliny says, "The bruscum is wonderfully fair, but the molluscum is counted most precious; both of them knobs and swellings out of the tree: the bruscum is more intricately crisped, the molluscum not so much; and had we trees large enough to saw into planks for tables, it would be preferred before citron; but now they use it only for small table-books, and its thin boards to wainscot bed-testers with. The brus-

* The knotted parts.

+ It has been observed in the article Cypress, that the citronwood of the ancients was from a kind of wild cypress. 
cum is of a blackish kind with which they make tables *."

Of these curious woods were made the famous tables called Tigrin and Pantherine; " not so named," says Evelyn, "from being supported with figures carred like those beasts, as some conceive, and was in use in our grandfathers' days, but from the natural spots and maculations. Such a table was that of Cicero's, which cost him 10,000 sesterces; such another had Asinius Gallus. That of King Juba was sold for 15,000; and yet that of the Mauritanian Ptolomee was far richer, containing four feet and a half diameter, three inches thick, which is reported to have been sold for its weight in gold. Of that value they were, and so madly luxurious was the age, that when the men at any time reproached their wives for their wanton expensiveness in pearls, and other rich trifles, they were wont to retort, and turn the tables upon their husbands + ."

Dr. Hunter observes that from this circumstance, related by Pliny, the common expression of turning the tables, appears to have been derived.

This ancient extravagance in tables has been ridiculed by many of the poets.

The Great Maple, Acer pseudoplatanus, grows in mountainous situations in Switzerland, Germany, Italy, \&r. With us, it is commonly known by the name of sycomore or sycamore-tree; it is also called the mock plane-tree, and the wild fig-tree. In Scotland, they call it simply plane-tree. We might call it mock-sycamore, since the true sycamore is an Egyptian tree, the leaves

* See Evelyn's Sylva.

+ Ibirl. 
of which resemble those of the mulberry-tree, and the fruit that of the wild fig; whence it was named from both, sycos signifying a fig and morus a mulberrytree.

Therenot mentions a curious tradition concerning one of these trees, which has also been related by other travellers: "At Matharee," says he, "6 is a large garden surrounded by walls, in which are various trees, and, among others, a large sycamore, or Pharaoh's fig, very old, which bears fruit every year. They say that the Virgin passing that way with her son Jesus, and being pursued by a number of people, this fig-tree opened to receive her; she entered, and it closed her in, until the people had passed by, when it re-opened; and that it remained open ever after to the year 1656, when the part of the trunk that had separated itself was broken away *."

The Great Maple is called in France, as with us, Sycomore or Faux Platane, Mock-plane: the Italians call it Acero Fico, Fig-maple.

This tree grows very high with a spreading top : it is in leaf by the middle of April, and the leaves on their first appearance are of a pleasant green, but they distil a clammy juice that is agreeable to insects, and they soon perforate and disfigure them. The flowers are full blown by the end of April, but they are of too green a colour to make much show.

The sycamore is good to plant near the sea, because it is not injured by the spray. An enormous sycamore is said to have grown at Knowle, in Kent, which is represented in Badeslade's view of that seat, and is preserved

* Thevenot's Voyage de Levant, part i. p. 265. 
in Dr. Harris's history of the county. It was twelve or fourteen feet in girth.

The original plantations of Vauxhall, and Mary-lebone Gardens, were chiefly of the sycamore. It is not considered as remarkable for longevity; Martyn mentions some in Cambridge, in a flourishing state at the age of 185 years.

In spring and autumn, this tree, if wounded, will pour forth an abundance of saccharine juice from the stem, from which may be made a good wine, and a tolerable sugar. There are two varieties of it, one with broader leaves, and one of which the leaves are variegated.

Before earthen-ware came into use at the table, the wood of this tree, which is soft and white, was in great request for trenchers; it is still used by the turners for bowls, dishes, \&c. by the saddlers for saddle-trees, and is recommended by Evelyn as excellent for cart and plough timber.

The shade of the sycamore is admirable, even the sight of it is cool and refreshing. The Maple bowls so often mentioned by our poets, (and still used on some occasions, even in London; as in the celebration of Lord Mayor's Day, \&c.) seem to be the offspring of the Sycamore, or Great Maple. The Maple-wood of the Romans was our British Maple; and from a passage in Virgil, Evelyn assumes a right to insist upon the respectability of its dimensions :

" Hæc ubi dicta, dapes jubet et sublata reponi Pocula, gramineoque viros locat ipse sedili; Præcipuumque toro et villosi pelle leonis Adcipit Enean, solioque invitat acerno."

Eneid viii. 
"Thus having said, the bowls (removed for fear) The youths replaced, and soon restored the cheer.

On sods of turf he set the soldiers round; A maple throne, raised higher from the ground, Received the Trojan chief; and o'er the bed A lion's shaggy hide for ornament they spread."

Dryden's Translation.

"Surely," says Evelyn, "there were some of them of large bulk and noble shade, that Virgil should choose it for the Court of his Evander (one of his worthiest princes in his best of poems) sitting on his Maple throne."

Ovid describes the Maple as "acerque coloribus impar" -" the mottled maple," that being the character for which it was so much valued by the Romans :

"The maple famed for wood of varied grain."

RAPIN.

This author compares it to the lime-tree :

"The maple not unlike the lime-tree grows, Like her, her spreading arms abroad she throws, Well clothed with leaves; but that the maple s bole Is clad by nature with a ruder stole."

A maple-bowl generally makes a part of the scanty furniture of a hermit's cell :

"His dwelling, a recess in some rude rock, Books, beads, and maple-dish, his meagre stock."

CowPER。

“ Many a visitant

Had sat within his hospitable cave, From his maple-bowl the unpolluted spring Drunk fearless, and with him partook the bread That his pale lips most reverently had bless'd With words becoming such a holy man!"

WIISON. 
66 It seem'd a hermit's cell,

Yet void of hour-glass, skull, and maple-dish."

Mason.

Dryden introduces it in a larger form into a housewife's cottage :

"Her parlour window stuck with herbs around Of savory smell, and rushes strew'd the ground:

A maple-dresser in her hall she had,

On which full many a slender meal she made."

The old lady was probably little aware, that she was in possession of property so valuable; and that the tree which furnished her homely dresser had been sought far and wide, and bought and sold at enormous prices by men of rank and power.

Thunberg speaks of the Maples of Japan as extremely beautiful. "For beauty," says he, " nothing can exceed the Maples indigenous of this country." And Dr. Clarke, travelling in a climate totally opposite to that of Japanon the borders of Lapland, and even on a mountain in that cold climate, says, "In our way up, we were astonished by the beauty and magnitude of the trees which we passed. Here we observed what is vulgarly called sycamore in our country, Acer Platanoides, spreading its luxuriant foliage among the proudest natives of the place *."

Browne mentions the sycamore as a rural tablet:

"Ye shady siccamours! when any swaine,

To carve his name upon your rind

Doth come, where his doth stand,

* Clarke's Travels, vol. iii. p. 219. 
Shed drops, if he be so unkind

To raze it with his hand."

$$
\text { W. BROWNE* }
$$

Sannazaro celebrates its shade :

"Non trovo tra gli affanni altro ricovero, Che di sedermi solo à piè d'un acero, D'un faggio, d'un abete, over d'uno sovero, Che pensando à colei, che 'l ror m'ha lacero !"

Egloga prima, dell' Arcadia.

"I find no other solace in my griefs, than to sit alone at the foot of a maple, a beech, a fir, or a cork-tree, thinking of her who rends my heart."

\section{Massinger says,}

" Here a sure shade

Of barren sycamores, which the all-seeing sun Could not pierce through."

Duke of Florence, act iv. s. ii.

Sir Philip Sidney gives it a place in his Arcadia :

"Neare whereunto overtaking her, and sitting downe together amonge the sweet flowers, whereof that place was very plentifull, under the pleasant shade of a broad-leaved sycamor, they recounted one to another their strange pilgrimage of passions, omitting nothing which open-hearted friendship is wont to lay forth, where there is cause to communicate both joyes and sorrowes."

The largeness of its leaf is one of the chief beauties of this fine tree; and Fairfax chooses this epithet for it, in the list of trees in the third book of his Tasso :

"The shooter yew, the broad-leaved sycamore, The barren platane, and the wallnut sound."

* On the death of his frierd Mr. T. Manwood, vol. iii. p. 66. 
Wordsworth also uses a very characteristic epithet:

"The staff I yet remember that upbore The bending body of my active sire; His seat beneath the honied sycamore Where the bees humm'd ; and chair by winter-fire."

Female Vagrant.

He describes it as serving the office of the box :

"On pipes of sycamore they play The fragments of a Christrnas hymn."

Idle Shepherd Boys.

Cowper describes the changes of its leaf in autumn :

"The maple, and the beech of oily nuts

Prolific, and the lime at dewy eve

Diffusing odours; nor unnoted pass

The sycamore, capricious in attire,

Now green, now tawny, and, ere autumn yet

Have changed the woods, in scarlet honours bright."

Task, book i.

Clare says of trees in autumn :

"A russet red the hazels gain, As suited to their drear decline; While maples brightest dress retain, And in the gayest yellows shine." 


\section{MEDLAR TREE.}

\section{MESPILUS.}

French, neflier; Italian, nespolo.

The Dutch Medlar, Mespilus Germanica, is a middlesized branching tree; the leaves are of an oval shape, but turning off to a point at the extremity (what the botanists term oval lanceolate), large, and rather woolly ; the blossoms are white, and large; and the fruit is a berry of the size of a smallish apple. This tree is a native of Asia, and the south of Europe; it blossoms in June and July. Both the trunk and the branches are commonly very crooked; the branches begin not far from the ground.

The fruit of the Medlar is not agreeable to the taste until it is in a state of decay :

"The medlar, fruit delicious in decay."

J. Philips.

This fruit bears on the top the form of a crown, which gives occasion to Cowley to say, -

" the medlar tree was found

Proud of its putrid fruit, because 'twas crowned."

Philips, speaking of grafted fruits, says,-

" men have gathered from the hawthorn's branch Large medlars, imitating regal crowns." 
Captain Stedman, in his expedition to Surinam, speaks of some medlars which were of a crimson colour, and in taste resembled strawberries*.

Chaucer describes a goldfinch eating the blossoms of the medlar :

"And as I stood and cast aside mine eye,

I was ware of the fairest medler tree

That ever yet in all my life I sie,

As full of biossomes as it might be,

Therein a goldinch leaping pretile

From bough to bough; and, as him list, he eet

Here and there of buds and floures sweet."

The Flower and the Leaf.

Mr. Miller describes the Wild Medlar as a different species, a native of Sicily, where, he says, it becomes a large tree, and grows with a straight stem, and that the leaves, flowers, and fruit are smaller than those of the Dutch Medlar.

The Bastard Quince, Mespilus Chamce-mespilus, which some botanists consider as a pyrus, grows five feet high ; the leaves have a yellowish tinge; the fruit is small, and red. It is a native of the Pyrenees, the mountains of Austria, the higher parts of Jura, the neighbourhood of Geneva, \&c. It was cultivated by Mr. J. Sutherland in 1683, and blossoms in May.

The Japan Mespilus, or Loquat, M. Japonica, which some of the most modem botanists have removed out of the genus and placed by itself, under the name of Chcenomeles Japonica, is a large and lofty tree; the taste of the fruit is something like that of an apple. It blossoms in Nay and June. 
The Dwarf Mespilus, M. Cotoneaster, which is in like manner denied a place among the mespili by some botanists, is a low spreading shrub, not more than two feet high : the leaves are alternate, the upper surface, bright green and smooth; the lower, white, woolly, and finely netted. The flowers are white, tinged with purple; the fruit is first green, it then becomes orange-coloured, afterwards red, and finally black. This is a native of many parts of Europe, and of Siberia: it blossoms in April and May. Mr. J. Tradescant, junior, cultivated this species in the year 1656 .

The Quince-leaved Mespilus, M. Tomentosa, which some botanists associate with the preceding to form a genus, Cotoneaster, grows about eight feet high. Its purple blossoms open in April or May; the fruit is round and large, and red when ripe. Mr. Miller had this in his garden in 1759 . 


\title{
MOUNTAIN-ASH TREE.
}

\author{
PYRUS AUCUPARIA.
}

POMACEA.

This tree is a species of service, called the mountain service: it is also called quicken tree, witchen tree, and roan, or rowan tree. It is here placed apart from the common service, only because it is now so generally known by the name of mountain ash, that many persons would not know it under that head. In Scotland it is as commonly called the roan tree. French, sorbier des oiseleurs, bird-catcher's service; Italian, sorbo salvatico.

The Mountain Ash is an elegant tree in all seasons of the year. The leaves are pinnate, (the reader will understand that a pinnate leaf, composed of several pairs of leaflets placed opposite at regular distances, in botanical language, is, in common parlance, a spray on which are placed so many leaves in pairs, notched at the edges, without footstalks, having a channeled mid-rib, often tinged with purple.

It is a native of the colder parts of Europe, as Mount Lebanon, Siberia, and in boggy and mountainous situations in the north of England, Wales, Scotland, and Ireland. In the south of England it is seldom found of any considerable size, but in the northern counties, and in Wales, there are large trees, although the growth is slow. The blossoms are white, and sweet scented; blowing in May, in little clusters or corymbs, and are succeeded by berries which, when ripe, are of a brilliant red colour. The blackbirds and thrushes are so fond 
of them, that they will not always give them time to ripen.

In Germany, the fowlers bait springes or nooses of hair with these berries, which they hang in the woods to entice the redwings and fieldfares: whence the French name, and the Latin specific name, which has a similar meaning.

It is said that the Mountain Ash berries, dried and powdered, will make a wholesome bread; and when we consider that the Swedish peasants are often reduced to subsist on bread made of the bark of the elm, fir, or birch tree, we may easily suppose that made of these berries would be a comparative luxury. An ardent spirit also is distilled from them, small in quantity, but of fine flavour. The Scottish Highlanders and the Kamtschadales make that use of them. Infused in water, they make an acid liquor, somewhat similar to perry, which is drunk by the Welsh poor, who call it DiodGraviole, or Ciavol-drink. In the island of Jura, their juice is used as an acid for punch.

The wood is used in mill-work,-for tables, chairs, \&c. : the roots are formed into knife and spoon handles. The fletchers commend it for bows, as second only to yew, and it is an excellent fuel.

Few persons, even of the inhabitants of London, are entirely unacquainted with the Mountain Ash, its elegant foliage, and glowing fruit ; or with the light and cheerful contrast it makes with the fir, or larch trees: but only those who have travelled northwards, we are told, have seen it in all its beauty. Mr. Gilpin says, that in the Scottish Highlands it becomes a considerable tree, and that a few of them interspersed with the dark pines and the waving birch have a very fine effect.

In old times the Mountain Ash was an object of great 
veneration; and it has been observed that a stump of it is frequently found in an old burying ground, or near the circle of a Druid temple, whose rites it formerly invested with its sacred shade.

Mr. Lightfoot remarks, that in these Druidical circles so often seen in North Britain, this tree is more frequently observed than any; and that some superstitious persons still believe that a part of it carried about them will preserve them from the effects of enchantment or witchcraft. The dairy-maid never neglects to drive her cattle to the shealings or summer pastures with a rod of the roan tree, and home again with the same. In Strathspey they make a hoop of its wood on the first of May, through which they make the sheep and lambs pass morning and evening.

Evelyn says this tree is reputed so sacred in Wales, that there is not a churchyard that does not contain one; and that on a certain day every person wears a cross made of the wood. Some authors give it the name of Fraxinus Cambro-Britannica, or Welsh Ash. "It is reputed," says Evelyn, "6 to be a preservative against fascination and evil spirits, whence perhaps we call it Witchen : the boughs being stuck about the house, or used for walking staffs."

Dr. Hunter, in his notes upon this author, says:66 In former times this tree was supposed to be possessed of the property of driving away witches and evil spirits, and this property is recorded in one of the stanzas of a very ancient song, called the Laidley Worm of Spindleston Heughs :

"Their spells were vain; the hags return'i

To the qucen, in sorrowful mood,

Crying that witches have no power

Where there is roan-tree wood." 
"The last line of this stanza," continues Dr. Hunter, "leads to the true reading of a line in Shakspeare's tragedy of Macbeth. The sailor's wife, on the witch's requesting some chestnuts, hastily answers, 'A rown tree, witch!' but all the editions have it 'Aroint thee, witch !' which is nonsense, and evidently a corruption." Dr. Hunter's suggestion appears so rational as almost to carry conviction with it, did we not require further elucidations of this strange term, where this sense can scarcely be made to apply. What means Edgar in King Lear?

"Saint Withold footed thrice the wold;

He met the night-mare, and her nine-fold;

Bid her alight,

And her troth plight,

And aroint thee, witch! aroint thee !"

This is generally supposed to signify araunt; but it is found in no other author than Shakspeare. Hone, in his Religious Mysteries, has a chapter on this subject, in which he gives a fac-simile of an old drawing, called the Descent into Hell, in which Christ is represented as approaching the mouth of hell, while a dievil addresses him, "Out, out, arongt," a word supposed to be a corruption of aroint; or rather they are both said to be corrupted from the word arougt. It would be too long, and perhaps not very interesting to readers in general, to quote all that relates to this subject: those who have any curiosity to see it will find it in the sixth chapter of that curious work : but a person animated with the zeal of a favourite theory might certainly perceive that the figure intended for Christ pays this visit under the protection of a roan-trce cross, which lie bears in the left 
hand, while with the right he appears to draw a contrite spirit from the jaws of hell.

Some think it should be printed anoint thee, instead of aroint thee. A witch, in Ben Jonson's Masque of Queens, exclaims,

"Sisters, stay, we want our dame;

Call upon her by her name,

And the charms we use to say;

That she quickly anoint, and come away."

Anoint would carry nearly the same meaning as avaunt: it would, at least, signify a preparation for departure; for it is understood of that amiable sisterhood, that when they wished to transport themselves from one place to another, they always anointed themselres, and sometimes the thing they rode on, whatever that might be. Some have inquired so deeply into this subject, as to know all the ingredients of the witch's ointment.

This is supposed to be the tree designed by Virgil, in the second Georgic, where he mentions sereral trees as being capable of grafting with others:

"Castaneæ fagus, ornusque incanuit albo

Flore pyri, glandemque sues fregere sub ulmis."

"Thus mastful beech the bristly chestnut bears, And the wild ash is white with blooming pears; And greedy swine from grafted elms are fed With falling acorns, that on oaks are bred."

Dexdex's Translation.

Modern gardeners, however, do not approve of grafting where there is no affinity.

A poet of our own times, and one whom all admirers 
of fine poetry have so much reason to regret, has noticed the height of this tree, and the freshness of its berries:

“ he was withal

A man of elegance, and stature tall :

So that the waving of his plumes would be High as the berries of a wild ash tree, Or as the winged cap of Mercury."

Keats's Early Poems, p. 25.

"But what is higher beyond thought than thee? Fresher than berries of a mountain tree?"

Keats's Sleep and Poetry. 


\title{
MULBERRY TREE.
}

\author{
MORUS.
}

The derivation of the word Morus is uncertain : some derive it from Mora, a delay, or impediment, the tree putting forth its leaves very late in the season; but it is more commonly derived from the Greek; - as referring to the redness of its juice, the blackness of its fruit, or, which is rather an odd notion, from a Greek word, signifying foclish; - by a kind of contradiction; the Mulberry being reputed the wisest of trees in not budding till the severe weather has entirely gone by: hence Pliny gives it the epithet sapientissima. After all these ingenious surmises, it seems the name may, with at least equal propriety, be derived from the Greek name for the tree itself. What character the Greeks intended to express by that name must be decided by the learned.

$$
\text { French, murier; Italian, moro. }
$$

THere are five species of the Mulberry-tree sufficiently hardy to bear our climate without protection; yet, notwithstanding their great beauty and utility, and the pains that have been taken to promote their cultivation in this country, they are rarely seen among us.

The White Mulberry, Morus alba, a native of China, Cochin-china, Japan, and Persia, was cultivated by Gerarde in 1596.

This species is cultivated for its leaves only, for the purpose of feeding silk-worms. It is in leaf a fortnight earlier than the next species.

The Common, or Black Mulberry, Morus Nigra, is a larger and stronger tree than the former, and is much 
esteemed for its dark juicy fruit. Evelyn says, the fruit of this tree, with the juice of cider-apples, makes an excellent and agreeable beverage. Old trees not only bear more fruit than young ones, but it is larger and better flavoured.

This tree is a native of Persia, whence it was brought to the south of Europe, and has been cultivated in every part of our continent, where the climate is not too serere. It will not live in the open air, in the northern parts of Sweden; and in some parts of Germany, it is trained against walls as we train peaches and other tender fruits. This species was brought to England in the same year as the White Mulberry.

Mrs. Holderness speaks of this tree as growing to a larger size in the Crimea than it is known to attain in any other country; and as being remarkable there for its luxuriance, and the perfection of its fruit*

The Red Mulberry of Virginia, Morus Rubra, is of quicker growth in this country than the two former, but is described by Martyn as not so easily propagated. Parkinson, in 1629, says it grows quickly to a great size; that the fruit is longer and redder than the common Mulberry, and of a very pleasant taste.

The Tartarian Mulberry, Morns Tatarica, is a shrub of which the trunk is seldom so large as the human arm : the fruit is small and insipid; it is, nevertheless, eaten fresh, in a conserve, or dried; and in Russia, a wine and a spirit are made from it.

All these species are used in feeding silk-worms, for which purpose nothing appears yet to have been dis-

* Mrs. Holderness's Manners and Customs of the Crim-Tartars. 
covered so valuable as Mulberry-leaves. In France, Italy, and some parts of Spain, the White Mulberry is chiefly cultivated for this use; in Granada, the leaves of the Black Mulberry are preferred. The Persians generally make use of the latter. Mr. Miller was assured by a gentleman who had tried both, that the worms fed with the Black Mulberry produced much the best silk.

James the First, excited by the success of Henry the Fourth of France, was very earnest to introduce the culture of silk into this country; and in the year 1608 caused a circular letter of his own writing to be sent to the Lord Lieutenant of every county, holding forth the example of France, observing that, from the experience of many private persons who had bred silk-worms for amusement, there appeared no reason to doubt but that they might be nourished and reared in England, if provision was made for planting Mulberry trees; and desiring those whom he addressed to "persuade and require" such persons as were able, to buy and distribute in the country mulberry plants, to the number of 10,000 , which were to be delivered in Eondon at the rate of three farthings each.

He likewise caused printed instructions to be published for planting and propagating Mulberry trees, and for rearing silk-worms. His Majesty's endeavours did not, however, succeed to any extent; nor was he much more fortunate in a similar attempt in the American colonies.

Evelyn, speaking of James's ill success, and of the revenue arising to the government of France from the culture of silk, ascribes its progress in that country, not to Henry the Fourth, but to the "indefatigable dili- 
gence of Monsieur Colbert, who so successfully revived it," continues he, "that it is prodigious to consider what an happy progress they have made in it; to our shame be it spoken, who have no other discouragements whatever but our sloth and want of industry ; since wherever these trees will grow and prosper, there the silk-worms will do so also. It is demonstrable that Mulberries, in four or five years, may be made to spread all over this land, and when the indigent and young daughters in proud families are as willing to gain three or four shillings a day for gathering silk, and busying themselves in this sweet and easy employment, as some do to get fourpence a day for hard work at hemp, flax, and wool, the reputation of Mulberries will spread in England and our plantations *."

The Paper Mulberry, Morns Papyrifera, is a native of China, Japan, and the South Sea islands; it was cultivated by Hugh, Duke of Northumberland, about the middle of the eighteenth century.

This tree takes its specific name from the use made of the bark by the Japanese. In December, after the leaves have fallen, they cut down the young shoots; these being divided into rods three feet in length, are gathered into bundles to be boiled; they are placed erect and close in a large copper, properly closed; and the boiling is continued till the separation of the bark shows the naked wood; after which, by a longitudinal incision, the bark is stripped off and dried, the wood being rejected.

* This amiable writer speaks with great disapprobation of the education of young women in his time.-See Sylva, Hunter's ed. vol. ii. p. 53. 
To purify the bark, they keep it three or four hours in water; and when it is sufficiently softened, the cuticle, which is of a dark colour, together with the greenish surface of the inner bark, is pared off; at the same time the stronger bark is separated from the more tender, the former making the best and whitest paper; the latter a dark and inferior kind.

A cloth also is made from this bark, which is worn by the principal people in Otaheite, and the Sandwich islands, and is the finest and whitest they have. Sometimes they dye it red.

They have an inferior kind of cloth made from the bread-fruit tree, which is chiefly worn by the lower orders; and a coarse and harsh kind from a tree resembling the wild fig tree of the West Indies; this is as dark as the darkest brown paper, but it is the most valuable cloth they have, because it resists water. This cloth is perfumed and worn by the chiefs in Otaheite, as a morning dress*.

The Mulberry tree is an excellent guide to the gardener, since the appearance of its leaves is an infallible sign that the severity of the season is over; there is no longer any danger from frost. "When the leaf of the Mulberry bursts forth," says Evelyn, " the gardener may safely expose his green-house plants." Pliny recommends the gardener to pay attention to this circumstance, as a guide on various occasions.

Horace recommends ripe Mulberries as a wholesome fruit :

* See Cook's Voyages, vol. ii.; or Martyn's edition of Miller's Gardener's Dictionary. 
« Ille salubres

Fistates peraget, qui nigris prandia moris Finiet, ante gravem quæ legerit arbore solem."

Satire iv. lib. 2.

"He shall with vigour bear the summer's heat, Who after dinner shall be sure to eat His mulberries, of blackest, ripest dyes, And gathered ere the morning sun arise."

Francis's Horace.

M. Dacier remarks upon this passage, that it has not been well understood: "The ancients," says he, " made but one meal, and those who could not stay till supper without eating, took some dry bread, raisins, figs, or mulberries, in the morning, and this repast was called prandium, gustus, \&c."

This remark is not mentioned with any intention of discussing the point here; but from a conscientious fear of misleading the reader in another important point, for M. Dacier proceeds to say, that however wholesome this fine fruit may be when eaten in the morning, it is by no means advisable to eat it after a variety of meats; and this assertion is supported by an authority no less than that of Galen*.

Dr. Clarke tells us, that he saw some Greeks in the Crimea employed in distilling brandy from mulberries; which he describes as "a weak but palatable spirit, as clear as water $\dagger . "$

We learn from Ovid that the Mulberry derives its fine colour from the blood of the two unfortunate lovers, Pyramus and Thisbe. He tells us that it was originally snow-white, but that when Pyramus, in despair upon the supposed death of his mistress, killed himself with

* See Dacicr's Horace.

$\uparrow$ Travels, Vol. i. p. 529. 
his own sword, he fell under the shade of this tree; Thisbe, finding him in this situation, followed his example, and their blood, flowing about the roots of the tree, was absorbed by them, and gave colour to the fruit:

"Arborei fœtus aspergine cædis in atram

Vertuntur faciem : madefactaque sanguine radix

Puniceo tingit pendentia mora colore."

$$
\text { Oviv, lib. iv. }
$$

"Dark in the rising tide the berries grew, And, white no longer, took a sable hue;

But brighter crimson springing from the root, Shot through the black, and purpled o'er the fruit."

\section{Orger's 'Translation.}

Cowley has spoken of the Mulberry tree at some length, and gives so correct an account of it, that, poorly as his poem has been translated, the reader will probably not object to the quotation of the passage :

"But cautiously the Mulberry did move, And first the temper of the skies would prove; What sign the sun was in, and if she might Give credit yet to winter's seeming flight: She dares not venture on his first retreat, Nor trusts her fruit or leaves to doubtful heat, Her ready sap within her bark confines, Till she of settled warmth has certain signs! Then, making rich amends for the delay, With sudden haste she dons her green array; In two short months, her purple fruit appears, And of two lovers slain the tincture wears. Her fruit is rich, but she doth leaves produce Of far-surpassing worth, and noble use.

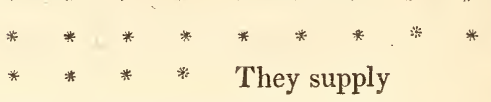

The ornaments of royal luxury: 
The beautiful they make more beautecus seem, The charming sex owe half their charms to them;

To them effeminate men their vestments owe; How vain that pride which insect worms bestow !"

Cow Ley on Plants, book v.

In the mind of an Englishman, the Mulberry tree will ever be intimately associated with the memory of our Shakespeare- of the world's Shakespeare-of Nature's Shakespeare. It is generally known that about the year 1609, when King James so zealously recommended the cultivation of Mulberry trees, Shakespeare, a loyal subject of nature and the king, planted one in his garden at New Place, Stratford. Mr. Drake mentions a person, the son of an alderman of Stratford, who in his youth remembered to have frequently eaten of the fruit of that tree, some of its branches hanging over the wall which divided that garden from his father's.

In the year 1\%42, Garrick, Macklin, and Dr. Delany were entertained under the shade of that noble tree, by Sir Hugh Clopton, at that time proprietor of New Place. By the executor of that gentleman, it was afterwards sold to the Rer. Francis Gastrell, Vicar of Frodsham in Cheshire. Why would this man fix such an ugly blot upon his own memory? This man, who was in possession of the house and garden of Shakespeare, of the very tree which he planted with his own hand; could he, is it possible he could, be so wholly destitute of common feeling as to destroy them? Surely he must have been utterly devoid of all soul, that such a neighbourhood did not inspire him with something like natural sensibility, even though he had it not before! It has been said that Pope's Willow was destroyed to relieve the lady to whom 
it belonged from the trouble of answering frequent applications for permission to see it: that was bad enough, quite lamentable enough, but that for such a paltry consideration, the world should have been deprived of Shakespeare's Mulberry tree, is monstrous indeed! This vicar, it seems, took a dislike to the tree, because it subjected him to the frequent importunities of trarellers, whose zeal might prompt them to risit it, and, " in an evil hour," says Mr. Drake, " the sacrilegious priest ordered the tree, then remarkably large, and at its full growth, to be cut down, which was no sooner done than it was cleft to pieces for firewood."

Could this Mr. Gastrell so strangely deceive himself as to believe that such a tree could be his property exclusively? Did he not know that it was the property of all England, that posterity had a share in it? How many years longer might that tree have lived and flourished; how long might art have preserved it, eren in decay; and who but Mr. Gastrell would have remored even the last lifeless rugged stump? who but would have cherished it while the least splinter remained! Some little solace it is, that the greater part of the wood was saved from the fire. It was purchased by Mr. Thomas Sharp, watchmaker, of Stratford, who, well knowing the value set upon it by the world, turned it much to his own advantage, by converting every fragment into little boxes, tooth-pick cases, tobacco-stoppers, \&c. which were sought after with aridity.

Having in 1756 destroyed the tree, it was not long before Mr. Gastrell completed the sacrilege by destroying the house also. Compelled to pay the monthly assessments towards the maintenance of the poor, (some part 
of which he hoped to escape by residing a part of the year at Lichfield; his servants, however, still living at New Place in his absence; ) he declared, in the violence of his anger, that that house should never be assessed again, "and," says Mr. Drake, "wishing, as it seems, to be damned to everlasting fame, the demolition of the New Place soon followed; for, in I759, he rased the building to the ground, disposed of the materials, and left Stratford amidst the rage and the curses of its inhabitants *."

* Drake's Shakespeare, vol. ii. p. 384. 


\section{MYRICA.}

The derivation of this name is uncertain; some consider it as of Greek origin, and bearing allusion to its growth near streams, others suppose it to be named from Myrrha, the daughter of Cynaras; Fable having converted her into this plant.

Tue Candleberry Myrtle, Myrica Gale, is also called Sweet Gale, Goule, Gaule, Sweet Willow, Wild Myrtle, Dutch Myrtle; and in Scotland, Gaal; in French, Le Gale Odorant, Le Piment Royal, Myrthe Bâtard, Myrthe du Brabant, Piment de Marais. It has many shrubby stalks which rise from two to four feet high; the blossoms appear before the leaves, with us in May : the leaves are an inch and a half long, and half an inch wide in the middle; they are alternate, of a cheerful green, rather stiff, and covered over with little resinous points, which being crushed, emit a fragrant odour. The catkins are yellowish-brown, sprinkled over with resinous particles, shining like gold. The bark is rust-coloured, dotted with white: the fruit is a coriaceous berry.

This shrub grows spontaneously in the northern parts of Europe, and in the bogs of North America : it is not uncommon in England, more particularly in the northern and western counties, and is also a native of Ireland, Scotland, and Wales. The leaves have a bitter taste, and are used in some parts of the Highlands, and in some 
of the Western Isles, instead of hops: a practice formerly common in many parts of the north of Europe.

The catkins being boiled in water, throw up a scum resembling bees-wax, which, gathered in sufficient quantity, would make good candles.

This shrub is used to tan calf-skin, and to dye wool yellow : the Welsh lay branches of it upon and under their beds, to keep off fleas and moths. In Jura the inhabitants garnish their dishes with it, and lay it among their linen to gire it a fine scent, and to drive away moths. When it grows within reach of a port, the sailors make besoms of it to sweep their ships. In the Isle of Ely, it is made into faggots, to heat orens. The leares, dried and powdered, are used as spice, as signified by some of the French names of the plant.

Before the tea shrub was so well known as it now is, it was asserted by Simon Pauli, that it was the same with our Sweet Gale*.

The American Candleberry Myrtle, Myrica cerifera, is a tree thirty feet high: the leaves are twice the size of the last, and evergreen; like the former giving out a grateful odour when bruised. The berry is often corered with a sort of meal. It flowers in May and June. This species was cultirated by the Duchess of Beaufort, in 1699.

In North America, candles are madie from the berries of this tree, whence it is called Tallow shrub; by some, more elegantly, the Candleberry tree. Others name it the Bay-berry bush. Like the former, it affects a wet soil, and agrees with the true myrtle in its love of the seashore. 
The candles made from these berries do not so easily bend or melt, in summer, as the tallow candles do ; they burn better and slower, cause no smoke, and yield rather a pleasant smell when extinguished.

A soap also is made from this wax, which has a pleasant scent, and is reckoned excellent for shaving: it is sometimes used as an ointment by surgeons. In Carolina, sealing-wax is made from these berries, and the root is considered as specific in the tooth-ache.

There are several other species from warm countries. Thunberg mentions one, a native of the Cape of Good Hope, which also is used for making candles. He gives a hasty sketch of the way in which they are made. It is there called the Wax shrub.

"The branches of the Wax shrub," says he "(Myrica cordifolia), the berries of which are covered with a fat substance resembling bees-wax, were put whole into a pot of boiling water, in order to melt and skim off the wax. It resembles grey impure wax, is harder than tallow, and somewhat softer than wax. The farmers use it for candles, and the Hottentots eat it like a piece of bread, either with or without meat *."

A little farther on he expresses himself nearly to the same effect. " "The berries," says he, "are quite round, full of knobs, soft, and of the size of a pea. The berries themselves are quite black, but covered with a farina of a whitish-grey colour. They are gathered in their ripe state in the month of March, and boiled in water till all the white powder is melted off, and floats on the surface of the water like fat; this, when skimmed off, and 
cooled, grows hard almost like wax, and is of a greenishgrey, or ash-colour. The farmers use it for candles, and the Hottentots eat it like so much cheese *.

This last shrub has been cultivated in England since 1759 .

* Thunberg's Travels, vol. i. p. 249. 


\section{NE'TLE TREE.}

\section{CELTIS.}

Called also the lote, or lotus tree. French, micocoulier; Italian, loto.

The European Nettle tree, Celtis Australis, or Blackfruited Lote tree, grows with an erect stem, forty or fifty feet high, with many slender branches: the leaves are alternate, about four inches long, and two broad in the middle. The flowers make no show ; the fruit is black, of the size of a pea.

It grows in the south of Europe to a great size: D'Asso mentions some in Spain prodigiously large and high. Martyn remarks, that "its fine regular spreading. head, and cheerful green colour, render this tree extremely proper for clumps in parks, groves, single trees, or avenues."

Cask-hoops and fishing-rods are made of the branches, and the berries are eaten by birds and boys.

The American Nettle tree, Celtis Occidentalis, has broader and shorter leaves than the former, and smaller fruit, which, when ripe, is dark purple. Where the soil is moist and rich, this tree grows very large. It blossoms in May, and the seed ripens in October. The leaves come out late in the spring, but it is the latest in fading of any deciduous tree. There is little beauty in the 
flowers or fruit; but the branches being well clothed with leaves, and the leaves of a fine green, the tree makes an agreeable variety in plantations.

The wood being tough and pliable, is esteemed by coach-makers for carriage-frames. In America, the fruit of this tree, which is generally called sugar-nut, is thought very pleasant eating. It is a favourite food with many American birds.

The Oriental Nettle tree, Celtis Orientalis, is a native of the Levant; it seldom grows higher than twelve feet, and divides into many branches, which spread horizontally on every side. The leaves are about an inch long, inclining to a heart shape; they are of a thicker texture, and a lighter green than those of the former kinds: the fruit is yellow, becoming darker as it ripens; the wood remarkably white.

Some have erroneously supposed the Celtis to be Homer's lotus :

"They went and found an hospitable race :

Not prone to ill, nor strange to foreign guest,

They eat, they drink, and nature gives the feast;

The trees around them all their food produce,

Lotus the name; divine, nectareous juice!

(Thence called Lotophagi) which whoso tastes,

Insatiate riots in the sweet repasts;

Nor other home, nor other care attends,

But quits his house, his country, and his friends."

Pope's Homer.

Evelyn says of it, that " it yields an admirable shade, and timber immortal, growing to a vast tree where it grows spontaneously, but its fruit seems not so tempting as it was storied it was to the companions of Ulysses." 
"And them amongst the wicked lotos grew, Wicked, for holding guilefully away

Ulysses' men, whom rapt with sweetness new,

Taking to host, it quite from him did stay."

SPENSER.

It is now pretty well ascertained, and generally believed, that Homer's lotus is a species of the rhamnus, a native of Barbary. Dr. Shaw, in his travels in that country, had frequent opportunities of examining this tree: he found it on the very borders of the country of the Lotophagi : others have found it in various parts; and it is supposed to be disseminated over the edge of the Great Desert, from the coast of Cyrene, round by Tripoli and Africa proper, to the borders of the Atlantic, the Senegal, and the Niger. Major Rennell saw it in Bengal, where it is called byre, and in dry places on the banks of the Ganges. The people there eat the fruit, as we do sloes and wild berries.

Pliny describes the fruit of the size of a bean, of a yellow colour, sweet, and pleasant-tasted: he says that it was bruised, made into a paste, and then stored up for food. A sort of wine was also made from it, resembling mead, but it would not keep many days. Pliny adds, armies in marching through that part of Africa have subsisted on the lotus.

Polybius, who was employed by Scipio Africanus to explore the coasts of Africa, says that the fruit is produced by a shrub which is rough and armed with spires, resembling the rhamnus in foliage; that when ripe, it is of the size of a round olive, is tinged with purple, and contains a hard stone : that being pounded, it is laid by for use; and that its flavour approaches to that of figs or dates : finally, that a kind of wine is made of it, by ex- 
pression, and diluted with water; that it affords a good beverage, but will not keep more than ten days.

Mr. Park describes the fruit as a small farinaceous yellow berry, of a delicious taste: the natives, he says, convert them into a sort of bread, by exposing them some days to the sun, and afterwards pounding them gently in a wooden mortar, until the farinaceous part is separated from the stone.

This meal is mixed with water and formed into cakes, which, when dried in the sun, resemble in colour and flavour the sweetest gingerbread. The stones afterwards being put into a vessel of water, are shaken about to separate the meal which may still adhere to them: this communicates to the water a sweet and agreeable taste, and, with the addition of a little powdered millet, makes a pleasant gruel, called fendi, which is the common breakfast in many parts of Ludomar, during the months of February and March.

Mr. Brown, also, says that the natives eat the fruit fresh, or dry; that when dry it is formed into a paste of pleasant flavour, and is a portable provision on journeys.

The wood of the Lotus tree was used by the ancients for flutes and other musical instruments.

Besides the tree Lotus, now called the Rhamnus Lotus, the ancients mention a herb of that name: Homer describes it as a food given to the horses of Achilles, and Virgil recommends it for sheep :

"At cui lactis amor, cytisum, lotosque frequentis Ipse manu, salsasque ferat præsepibus herbas."

Georgic. iii.

"But those who desire to have milk must give them with their own hands plenty of water-lilies, and lay salt herbs in their cribs."

MaRTyN's Translation. 
The word Lotus is here translated water-lily, for it is generally supposed to have been the plant now called Nymphæa Lotus, a kind of white water-lily. There is a genus now bearing the name of Lotus, which has no connexion with either Lotus of the ancients; -it is called in English the bird's-foot-trefoil. 


\section{NEW JERSEY TEA TREE.}

\section{CEANOTHUS AMERICANUS.}

RHAMNE尺.

PENTANDRIA MONOFYNIA.

French, ceanothe; Italian, ceanoto.

The American Ceanothus, or New Jersey Tea Tree, seldom grows higher than four feet in England, but being much branched, from the ground upwards, and well clothed with oval leaves of a light cheerful green, it makes a pretty variety, more especially in July, when it is in blossom. The flowers, though small, are of a clear white, and so numerous, that the whole shrub appears covered with them. In mild seasons this shrub will flower again in October.

The Ceanothus affords a dye for wool, of a fine nankeen cinnamon colour; its leaves are dried, and used in America as tea.

This shrub was cultivated in the episcopal garden at Fulham, in 1713, but was afterwards lost in England for many years, and again introduced from America. It is now not uncommon in our gardens and nurseries.

There is an evergreen species of Ceanothus, which is a native of the Cape, and has been cultivated here since 1712. It seldom produces flowers in this country, but its bright green leaves make a pretty variety in the green-house during the winter; for this last species must have winter protection; the former will bear this climate very well. 


\section{OAK TREE.}

QUERCUS.

French, chêne; Italian, quercia.

There are many species of Oak, which to describe, with their uses ancient and modern, and all the fables or histories connected with them, would be to write a volume upon that subject only,-and a volume of considerable magnitude. For the present purpose it will suffice to notice a few of the more important.

Among the American Oaks are several species which are evergreen. Of those which are natives of Europe, there is but one properly so called, though others are sometimes termed so, because they generally retain their leaves until the shooting of new ones drives off the old. It has been observed of the Oak, that the foliage is

"Tenacious of the stem, and firm against the wind."

The Kermes Oak, Quercus coccifera, is of humble growth, and chiefly mentioned on account of a red gall collected from it, occasioned by the puncture of an insect called the coccus ilicis. This furnished the ancients with a scarlet dye, called coccus, or coccineus, which superseded the purpura obtained by the Phœnicians from the shellfish murex, and supported its reputation until the dis. covery of America, when it yielded to the cochineal, an 
insect found upon the cactus, or Indian fig, in the woods of Mexico.

This species is a native of the Levant, and of the south of Europe, and was cultivated here in 1683, by Mr. J. Sutherland.

The Italian Oak, Quercus Esculus, is by some persons supposed to be the Esculus of the Romans; others suppose the Esculus to have been a variety of our Common Oak, called the Sessile-fruited. Authors are by no means agreed upon this subject, which still remains a question with those who are curious in these things.

The Italian Oak has been named Esculus, from the esculent quality of the acorns, which, in times of scarcity, are frequently eaten by the poor in the south of France, ground, and made into bread: some eat them fresh like nuts; they are sweet, and very different from our English acorns.

This Oak was cultivated by Mr. Miller in 1739 .

The Red Oak, Quercus rubra, is a North American, and in its native land grows very large; the leaves are of a bright green, which they preserve until very late in the autumn. This species was cultivated by Bishop Compton in 1691. There are several varieties; the Champion, the Scarlet, and the Mountain Red Oak.

The Common Oak, or as some call it, the English Oak, Quercus Robur, is too well known to need description : of this species there are usually enumerated three varieties*, the Stalk-fruited, the Sessile-fruited, and the Dwarf: but the most modern botanists consider them as separate species, and name them Quereus pedunculata, Q. robur, and Q. nana. 
The wood of this Oak is hard, tough, tolerably flexible, and not easily admitting water; it is strong, without being too heavy, and not apt to splinter. For these qualities, it is valued for building ships. 6 "There is a kind of it," says Evelyn, "so tough and compact, that our hardest tools will hardly enter it."

"The most valued qualities of the Oak," remarks Mr. Gilpin, "are hardness and toughness. Box and ebony are harder, yew and ash are tougher than the oak, but no timber is possessed of both these qualities together in so great a degree as the British Oak."

The sawdust is an ingredient in many brown and drabcoloured dyes; the Oak apples, also, are used in dyeing, as a substitute for galls. The bark is used in tanning leather, and afterwards is valuable to the gardeners in raising many tender plants. A blue dye for wool is prepared by infusing Oak bark with a little copperas; it is not particularly brilliant, but is very lasting.

The leaves are often dried and used for litter; these, too, are serviceable to the gardeners; there is a honeydew upon them, in which bees take great delight. The aphis of the Oak extracts the juice from the leaves, which is afterwards passed through her horns, and forms the honey-dew so grateful to flies and bees. Linnæus has given to this aphis the name of the ant's milch-cow, because that interesting little creature is said to drink the juice from its horns.

Roucel, in his Flora du Nord de France, says that "6 these acorns, roasted, ground, and made into bread, have been eaten in times of scarcity; that they may be used as coffee, which they resemble in flavour, and that so used they have the property of strengthening the nerves: he says the fresh fruit has an agreeable taste, and may 
be eaten like nuts, or chestnuts*." They must be considerably improved by the soil and climate of France.

The Ilex, Evergreen, or Holm Oak, Quercus ilex, is a native of the south of Europe, Cochinchina, and Barbary. Gerarde speaks of it, in 159\%, as a stranger in Engyland; "notwithstanding there is here and there a tree thereof that has been brought from beyond seas." The French call this tree Chêne vert; the Italians, Elice, or Leccio. It is not easy to describe the leaf, for one individual will often be clothed with foliage of different kinds : some are sinuated, and set with prickles; others are smaller, and neither sinuated nor prickled; they are of a lucid green, and their length is commonly from three to four inches; the under side is rather downy. The acorn is of the same shape as that of the Common Oak, but smaller.

There is a variety of this, by some called the Spanish Oak, of which the acorns are eaten either raw or roasted. This may be the Ilex to which the Spanish poet alludes in these lines:

" hast thou forgotten, too,

Childhood's sweet sports, whence first my passion grew, When from the bowery ilex I shook down

Its autumn fruit, which on the craig's high crown

We tasted, sitting, chattering, side by side?

Who climbed trees swincing o'er the hoarse deep tide, And poured into thy lap, or at thy feet Their kernelled nuts, the sweetest of the sweet? When did I ever place my foot within The flowery vale, brown wooci, or dingle green, And culled not thousand odorous flowers, to crest Thy golden curls, or breathe upon thy breast?"

WIFFEN"S Garcilasso, p. 215.

* Vol. ii. p. 338. 
The fruit must, indeed, be very superior to that of our oaks, for no English lover would pride himself upon feeding his mistress with acorns, and call them the sweetest of sweet kernels. This must be the tree of which the poet speaks : it would be yet more strange to feed her with holly-berries than with English acorns; and it has been observed that in France, Spain, \&c. acorns are eaten as nuts. They are described as really sweet and pleasant; and, were they not so, tastes differ no less than fruits; and we are told that in old times the beech-nut was thought preferable to the sweet chestnut; and some writers passed their jokes upon the singular care with which so useless and undesirable a kernel as the latter was defended from injury by its armed shell. Gerarde, too, calls the horse-chestnut a sweet and pleasant food : if he spoke this from experience, and not from mere conjecture or hearsay, we need not wonder that acorns of any kind should be considered as a luxury.

Strabo says, that in the mountainous parts of Spain, the inhabitants ground their acorns into meal ; and Pliny affirms, that in his time acorns were brought to table with the dessert, in Spain. Cervantes, too, describes 'Theresa as collecting the best acorns she could find, to send as a present to the duchess.

Garcilasso again mentions the Ilex, in company with the Oak commonly so called:

"But in calm idlesse laid,

Supine in the cool shade

Of oak, or ilex, beech, or pendant pine,

Sees his flocks feeding stray

Whitening a length of way,

Or numbers up his homeward-tending kine."

P. 198. 
'The ilex grows much quicker than the Common Oak, and the wood is tougher. It was not brought into general cultivation here till the beginning of the eighteenth century. There is a variety called the Holly-leaved Oak, which some botanists consider as a different species, under the name of Quercus Gramuntia.

There is a species called the Chestnut-leaved Oak, Quercus prinus, of which the foliage is so similar to that of the chestnut tree, that it is not immediately to be distinguished from it.

The Velani Oak, Quercus Agilops, is a very fine tree; a native of the Levant, and of the south of Europe. The acorns are brought from the Levant for dyeing : they are called Valonia, from the Romaic name of the tree : they are very large, and have scaly cups, nearly the length of the fruit.

An Englishman claims a right to the Oak, as though no other country possessed such a tree, or no other Oak were to be compared with the British. Virgil has praised the Esculus, and the Esculus is understood to be an Oak; surely then it must be ours! Pliny has praised the Phagus, and that is supposed to be an Oak; then that, too, must be ours. It is an awkward fact that the Oak is generous enough to bestow itself upon any tolerably temperate climate; it is not fastidious in soil, but will not bear a very cold, or a very warm climate. America boasts of very fine Oaks, of many species, especially one called the Live Oak: it were a dangerous temerity to say that the British Oak is not the sovereign of them all, nay, of all trees whatsoever : it were a temerity not to be feared from one of British birth; and Britain, at least, may boast of having turned it to the best account, and, paid it the most grateful homage. The Romans only 
can compare with the English in the value they have set upon this noble tree.

England has borne some magnificent Oaks. Evelyn mentions two that grew in Suffolk, which were of immense size, and were used in building the Royal Sovereign; another, that shaded a circumference of five hundred and sixty yards; under which two thousand four hundred and twenty men could find convenient shelter; and a yet larger, near the gate of the water walk at Magdalen College, of which the branches stretched sixteen yards from the stem. Of this last, Dr. Hunter tells us, that it was blown down on the 29 th of June 1\%89, after having stood on classic ground nearly five hundred years. It was generally known by the name of Addison's Oak, Addison having shown a regard for it by placing a bench under its shade, on which he frequently reposed himself after walking.

In Lord Norris's Park, at Rycote, was an Oak, of which Evelyn says "it extended its arms fifty-four feet, under which three hundred and four horses, or four thousand three hundred and serenty-four men may sufficiently stand."

Martyn speaks of three Oaks planted by Chaucer in Dennington Park, which grew to a great size; one was called the King's, the second the Queen's, and the third, Chaucer's Oak.

At Morley, in Cheshire, grew an Oak, supposed when measured to be eight hundred years old; the trunk, which was hollow, was forty-two feet in circumference; it had for many years been used for housing cattle. Tradition says that Edward the Black Prince once dined - under its shade.

The boughs of an Oak in Worksop Park measured, 
from one extremity to the other, a hundred and eighty feet.

Another, measuring but half this width, is remarkable for uniting under its shade the counties of York, Derby, and Nottingham, whence it is called Shire Oak.

The Cowthorpe Oak, in Yorkshire, of which there are prints in Hunter's Evelyn, was eighty-five feet high, and the trunk seventy-eight feet round.

The Boddington Oak, in the Vale of Gloucester, measured fifty-four feet in the circumference of the trunk.

An Oak in Shropshire measured sixty-eight feet round, and one in Welbeck Park, Nottinghamshire, called the Duke's Walking-stick, was a hundred and eleven feet high.

The Greendale Oak, in Nottinghamshire, of which there are several views in Hunter's Evelyn, was eightyeight feet high, the trunk thirty-three feet one inch round; and it was, when measured, above seven hundred years old. Carriages have been driven through the hollow trunk of this tree, but it is now fenced round by the care of the Duke of Portland, to protect it from the ravages of wanton or curious visiters.

At Fairlop, in Essex, grew an Oak, of which the trunk measured thirty-six feet round, the circumference of the boughs at their extent was three hundred feet. It was a custom for the blockmakers of Wapping to hold an annual meeting under its shade on the first Friday in July, which festival was founded by Mr. Daniel Day, a blockmaker of that place, who always dined under it on that day with a select party of friends. The visitants proceeded there in boats, placed on carriages, and ornamented with flags, which collecting much idle rabble, this oak is now cut down, and the pulpit and 
reading-desk of Saint Pancras church, Euston Square, have been made from its timber.

The trunk of Damory's Oak, in Dorsetshire, measured sixty-eight feet round; as this large trunk decayed, it formed a carity fifteen feet wide, and seventeen high, capable of containing twenty men. During the civil wars after the Restoration, this was inhabited by an old man who sold ale in it. By the storm of 1703, it lost some of its noblest limbs. In 1755 , when fit for nothing but firewood, it was sold for $14 l$.

In Suffolk is, or was very lately, an Oak of which the trunk measured thirty-five feet round. It was hollow in the time of Queen Elizabeth, of whom it is reported that, in her youth, she would often take her stand under it to shoot at the deer as they passed. It is hence called Queen Elizabeth's Oak. This does not appear an occupation worthy of Elizabeth.

Of Fisher's Oak, a tree of immense bulk, about $1 \tau$ miles from London, in the way to Tunbridge, it is said that when King James the First travelled that way, a schoolmaster of the neighbourhood, and all his scholars, decked with oaken garlands, came out of the tree in great numbers, and entertained the king with an oration. They have a tradition at Tunbridge that thirteen men on horseback were once sheltered within that Oak.

In Stirling are the ruins of an old Oak supposed to have been the largest tree that erer grew in Scotland; around which are the restiges of one of those circles attributed to the Druids. When William Wallace roused the Scotch to oppose Edward, he often assembled his army at Torwood, and this Oak is said to have been his head-quarters. Hence it has ever since borne the title of Wallace's Oak. 
There is an Oak in the New Forest; near Cadenham, and called the Cadenham Oak, which is remarkable for budding every year in the depth of winter, like the Glastonbury Thorn; it is said by the country people to produce its buds always on Christmas-day. These premature buds, after unfolding themselves, make no further progress, but wither away, and the tree again regetates in the usual season, in the same manner as others of its species.

An Oak was planted at Penshurst, on the day of Sir Philip Sidney's birth, of which Martyn speaks as standing in his time, and measuring twenty-two feet round. This tree has since been felled, it is said by mistake: would it be impossible to make a similar mistake with regard to the mistaker?

Several of our poets have celebrated this tree; Ben Jonson, in his lines to Penshurst, says

"Thou hast thy walks for health as well as sport;

Thy mount to which thy Dryads do resort,

Where Pan and Bacchus their high seats have made,

Beneath the broad beech and the chestnut shade.

That taller tree which of a nut was set,

At his great birth where all the muses met.

There in the writhed bark are cut the names

Of many a sylvan taken with his flames."

It is mentioned by Waller :

"Go, boy, and carve this passion on the bark

Of yonder tree, which stands the sacred mark

Of noble Sidney's birth."

Southey says, speaking of Penshurst :

" Sidney here was born,

Sidncy, than whom no gentler, braver man, 
His own delightful genius ever feigned, Illustrating the vales of Arcady

With courteous courage, and with loyal loves.

Upon his natal day the acorn here

Was planted; it grew up a stately Oak, And in the beauty of its strength it stood And flourished, when his perishable part Had mouldered dust to dust. That stately Oak Itself hath mouldered now, but Sidney's name Endureth in his own immortal works."

This tree was frequently called the Bare Oak, by the people of the neighbourhood, from a resemblance it was supposed to bear to the Oak which gave name to the county of Berkshire. Tradition says that when the tenants went to the Park-gates, as it was their custom to do, to meet the Earls of Leicester when they visited that castle, they used to adorn their hats with boughs from this tree. Within the hollow of its trunk, was a seat which contained five or six persons with ease and convenience.

The Oak at Boscobel which sheltered Charles the Second after the battle of Worcester, was in great repute in the last century; and many trees were raised from its acorns. The king visiting the spot some time after, took some of the acorns away, which he set in St. James's Park, and used to tend and watch their growth himself. It is said that one of those trees was removed from thence at the building of Marlborough House. It is still customary, on the 29th of May, the Restoration of Charles the Second, for the common people to wear Oak leaves or Oak apples in their hats; some adorn them with leafgold; but the custom is gradually declining.

"I have been told," says Evelyn, "that there was an intention to institute an Order of the Royal Oak; and 
truly I should think it would become a green ribbon, next to that of St. George, superior to any of the romantic badges to which such veneration is paid abroad; deservedly to be worn by such as have signalized themselves by their conduct and courage in the defence and preservation of their country."

At Worthorpe, in Lincolnshire, is an Oak, in the hollow trunk of which six calves are fattened every season.

" A tree is still shown in Windsor Forest, as Herne's Oak," says Martyn, but from its size and vigour he doubts whether it could have been a proper tree for Herne the hunter to have danced round more than two centuries ago. Whether the tree be actually standing or not, its memory will live, while there lives a man to cherish it.

"_ The fairies from their nightly haunt In copse, or dell, or round the trunk revered Of Herne's moon-silvered oak, shall chase away Each fog, each blight, and dedicate to peace Thy classic shade."

W. Tighe.

Many places in England take their names from the Oak tree, as Berkshire from a bare Oak-

"An aged oak, of leaves and branches bare,"

at which the people of that county used to assemble: Oakingham, Oakhampton, Oakington, Aukland, Baldock, Hatfield Broad-oak, Acca in Somersetshire, Greenock in Scotland, Seven Oaks, \&c.

Virgil has, as Mr. Gilpin observes, in a few words brought together the most obvious qualities of this noble tree; its firmness, the stoutness of its limbs, the twisting of its branches, their wide-spreading, and its longevity, 
which he supposes to exceed that of every other tree, except, perhaps, the yew.

" Esculus in primis, quæ, quantum vertice ad auras Etherias, tantum radice in Tartara tendit. Ergo non hiemes illam, non flabra, neque imbres Convellunt: immota manet, multosque nepotes, Multa virum volvens durando sæcula, vincit; Tum fortis late ramos et brachia tendens Huc illuc, media ipsa ingentem sustinet umbram."

Georgic ii.

66 Jove's own tree

That holds the woods in awful sovereignty, Requires a depth of lodging in the ground; And, next the lower skies, a bed profound. High as his topmost boughs to heaven ascend, So low his roots to hell's dominion tend. Therefore nor winds, nor winter's rage o'erthrows His bulky body but unmoved he grows. For length of ages lasts his happy reign, And lives of mortal men contend in vain : Full in the midst of his own strength he stands, Stretching his brawny arms, and leafy hands; His shade protects the plains, his head the hills commands."

DRYDEN.

In the Eneid, speaking of the Oak by the name of Quercus, the poet uses the same expression with regard to the depth of its roots :

"Ac velut, annoso validam quum robore quercum Alpini Boreæ nunc hine nunc flatibus illine Eruere inter se certant; it stridor, et alte Consternunt terram concusso stipite frondes: Ipsa hæret scopulis : et quantum vertice ad auras Etherias, tantum radice in Tartara tendit." 
"As when the winds their airy quarrel try, Jostling from every quarter of the sky, This way and that the mountain oak they bend, His boughs they shatter, and his branches rend; With leaves and falling mast they spread the ground, The hollow valleys echo to the sound:

Unmoved the royal plant their fury mocks, Or shaken, clings more closely to the rocks; Far as he shoots his towering head on high, So deep in earth his fixed foundations lie."

Dryden's Virgil.

"T The Oak," observes Mr. Gilpin, "6 is confessedly the most picturesque tree in itself, and the most accommodating in composition. It refuses no subject, either in natural, or in artificial landscape. It is suited to the grandest, and may with propriety be introduced into the most pastoral. It adds new dignity to the ruined tower, and Gothic arch; it throws its arms with propriety over the mantling pool, and may be happily introduced even in the lowest scene."

"Imperial oak, a cottage in thy shade Finds safety, or a monarch in thy arms :

Respectful generations see thee spread,

Careless of centuries, even in decay

Majestic : thy far-shadowing boughs contend

With time; the obsequious winds shall visit thee,

To scatter round the children of thy age,

And eternize thy latest benefits."

\section{W. Tighe.}

"It is remarkable," says Dr. Hunter, "6 that the Oak was held sacred by the Greeks, the Romans, the Gauls, and the Britons."

It is frequently mentioned by the Roman poets as the tree of Jove, to whom it was dedicated. Near to Chaonia 
(a mountainous part of Epirus, so called from Chaon, one of the sons of Priam), was a forest of Oaks, called the Chaonian, or Dodonean Forest, where oracles were given, as some say, by the trees themselves; according to others, by the winds of the forest that whispered through them; and others maintain that they were pronounced by sacred doves. Virgil sometimes applies the epithet Chaonian to Jove himself, from this forest, which was consecrated to him :

" Chaoniique patris glandes :"

"The acorns of our Chaonian father."

Ovid distinguishes the Chaonian Oak from the Esculus. Among the trees assembled to hear the lyre of Orpheus, he mentions the Chaonian tree:

"Chaonis abfuit arbos."

And afterwards the Esculus :

"___ non frondibus esculis altis."

Speaking of the simple food of the ancients; as the fruit of the Arbutus, \&c. he adds,

" Et quæ deciderant patula Jovis arbore glandes."

"And acorns dropping from the tree of Jove."

Dr. Orger's Ovid.

Lucan, speaking of trees felled in a sacred wood, says,

"Then Jove's Dodonean tree was forced to bow."

Rowe's Lucan.

Wordsworth alludes to the oracle of Jupiter: 
"Oak of Guernica! Tree of holier power

Than that which in Dodona did enshrine, (So faith too fondly deemed) a voice divine, Heard from the depths of its aerial bower, How canst thou flourish at this blighting hour? What hope, what joy can sunshine bring to thee, Or the soft breezes from the Atlantic sea, The dews of morn, or April's tender shower?

Stroke merciful and welcome would that be Which would extend thy branches on the ground, If never more within their shady round Those lofty-minded lawgivers shall meet, Peasant, and lord, in their appointed seat; Guardians of Biscay's ancient liberty."

In Ford's play of the Sun's Darling, Winter thus reproves the clowns:

"Yet you, wild fools, possessed with giant rage,

Dare, in your lawless fury, think to wage

War against heaven; and from his shining throne

Pull Jove himself, for you to tread upon;

Were your heads circled with his own green oak,

Yet they are subject to his thunder-stroke."

It is well known that in the early ages, acorns were an importan $\uparrow$ species of food: the substitution of corn, in ancient Rome, was attributed to the bounty of Ceres, who, by means of Triptolemus, taught them its use and cultivation :

"Liber, et alma Ceres; vestro si munere tellus

Chaoniam pingui glandem mutavit arista, Poculaque inventis Acheloïa miscuit uvis."

Virgit, Georgic i.

"Bacchus, and fostering Ceres, powers divine, Who gave us corn for mast, for water wine."

DRYDEN̦'s Virgil. 
Martyn observes, that Virgil poetically speaks of Chaonian or Dodonean acorns for acorns in general, those being the most celebrated. It appears that, when speaking merely of the trees or acorns, the word Chaonian is commonly used, but in such passages as relate to Jove, or to the sacred oracles, directly or indirectly, we generally find the word Dodonean. This, however, is by no means invariable: witness the following passage from Virgil ; yet this bears some reference to the sacred nature of the place:

"Prima Ceres ferro mortalis vertere terram Instituit: quum jam glandes atque arbuta sacræe Deficerent silvæ, et victum Dodona negaret."

Georgic i.

"Ceres first taught mankind to plough the ground, when mast and arbutes began to fail in the sacred wood, and Dodona denied them sustenance."

\section{MarTyN's Translation.}

Spenser also alludes to this circumstance: the goddess was supposed to have instructed Triptolemus in agriculture, and to have lent him her chariot, in which he travelled all over the earth, distributing corn to the inhabitants :

"The oak, whose acorns were our food, before That Ceres' seed of mortal man was known, Which first Triptoleme taught how to be sown."

In gratitude and commemoration of this gift, the Oak was worn in the festivals in honour of Ceres, as also by the husbandmen in general, at the commencement of the harvest. There is an old Greek proverb, in which a man's age and experience are expressed by saying that he had eaten of Jove's acorns. 
A Roman, who saved the life of another, was crowned with a chaplet of Oak. There is an allusion to this custom in Shakespeare's Coriolanus; Cominius, speaking of him, says,

" At sixteen years,

When Tarquin made a head from Rome, he fought

Beyond the mark of others; our then dictator,

Whom with all praise I point at, saw him fight,

When with his Amazonian chin, he drove

The bristled lips before him: he bestrid

An o'erpressed Roman, and i' the consul's view

Slew three opposers: Tarquin's self he met,

And struck him on his lance: in that day's feats,

When he might act the woman on the scene,

He proved best man i' the field, and for his meed

Was brow-bound with the oak."

Act ii. Scene 2,

Lucan also refers to it :

"Straight Lelius from amidst the rest stood forth, An old centurion of distinguished worth;

The oaken wreath his hardy temples wore, Mark of a citizen preserved he bore."

Rowe's Lucan, book i.

Boughs of Oak were carried in nuptial ceremonies:

"With boughs of oak was graced the nuptial train."

The religious ceremonies of the druids were performed under the shade of the Oak, which they venerated; and the cutting of the misletoe was an important ceremony with them. They called this plant All-heal, from the healing power it was supposed to possess in their hands. They cut it at Christmas, with brazen hatchets : misletoe is a parasite of other trees as well as of the Oak; but it 
was only that which grew on the Oak that was cut by the druids, or possessed healing powers.

Though tributary to Jupiter, the Oak is itself a sovereign, as may be gathered from undoubted authorities :

"And like the oke, the sovran of the woode ;"

says Chatterton. He speaks of its majestic appearance; calls it

$$
\text { "_ The oke, of lordly look." }
$$

And again, he compares it to a majestic woman :

"Majestic as the grove of okes that stoode

Before the abbie built by Oswalde, kinge ;

Majestic as Hybernie's holy woode,

Where saintes and soules departed masses synge ;

Such awe from her sweete looke forthe issuynge

At once for reveraunce and love did calle."

Dodsley, in his poem on agriculture, after naming many other noble trees, proceeds :

"And last the oak, king of Britannia's woods, And guardian of her isle."

Cowper terms it

"Lord of the woods, the long-surviving oak."

Spenser gives it very extensive dominions :

“ The builder oak, the king of forests all."

And Fairfax even vouches for its coronation :

"Oak, the king of forests crowned."

Churchill goes so far as to affirm that, after death, it is but translated to another sovereignty : 
"The oak, when living, monarch of the wood, The English oak which, dead, commands the flood."

Montgomery speaks of the longevity of this sturdy tree :

" As some triumphal oak, whose boughs have spread Their changing foliage through a thousand years, Bows to the rushing wind its glorious head."

These lines present us with a fine and stately picture of the Oak. Mason puts it in a venerable point of view :

" Hie thee, poor pilgrim, to yon neighbouring bower, O'er which an old oak spreads his aweful arms, Mantled in brownest foliage : and beneath, The ivy, gadding from the untwisted stem, Curtains each verdant side."

\section{ELFRIDA.}

“ Happy foresters,

Ye wave your bold heads in the liberal air:

* $\quad * \quad * \quad * \quad * \quad * \quad *$

Ye with your tough and intertwisted roots,

Grasp the firm rocks ye sprung from, and erect

In knotty hardihood, still proudly spread

Your leafy banners 'gainst the tyrannous north."

Caractaces.

Metastasio celebrates it for its sturdy defiance of the winds :

" Sprezza il furor del vento

Robusta quercia avezza

Di cento verni e cento

L'injurie a tollerar.

E se pur cade al suolo, Spiega per l'onde il volo, E con quel vento istesso

Va contrastando in mar." 
These lines are translated by Montgomery:

" The tall oak, towering to the skies, The fury of the wind defies, From age to age in virtue strong, Inured to stand and suffer wrong.

O'erwhelmed at length upon the plain, It puts forth wings, and sweeps the main; The self-same foe undaunted braves, And fights the wind upon the waves."

Wordsworth speaks of the Oak's fine broad shade :

"Beneath that large old oak, which near their door Stood, and, from its enormous breadth of shade, Chosen for the shearer's covert from the sun, Thence, in our rustic dialect was called The Clipping-tree; a name which yet it bears."

The poet adds a note to explain that clipping is a word used in the north of England for shearing.

Spenser compares a grey-headed old man to an old Oak tree covered with frost :

"There they do find that godly aged sire, With snowy locks adown his shoulders shed, As hoary frost with spangles doth attire The mossy branches of an oak half dead."

Age, borne up by mental strength to a stout defiance of misfortune or danger, has frequently afforded a simile with the oak tree past its prime:

"Silent and tall he seemed as an oak on the banks of Lugar, which had its branches blasted of old by the lightning of heaven. It bends over the stream; the grey moss whistles in the wind. So stood the king." 
Chatterton repeatedly compares the deach of a warrior, in battle, to the fall of an oak:

"In his dere hartes bloude his longe launce was wett, And from his courser down he tumbled dede. So have I sene a mountayne oak that longe Has caste his shadowe to the mountayne syde, Brave all the wyndes, tho' ever they so stronge, And view the briers below with self-taught pride;

But when throwne downe by mightie thunder-stroke, He'd rather bee a brier than an oke."

Cowley compares the death of the gigantic Philistine slain by David to a tree destroyed by thunder:

" Down, down, he falls, and bites in vain the ground;

Blood, brain, and soul crowd mingled through the wound!

So a strong oak which many years had stood

With fair and flourishing boughs, itself a wood-

'Though it might iong the axe's violence bear, And played with winds that other trees would tearYet by the thunder's stroke from the root is rent: So sure the blows that from high heaven are sent."

The Oak is not so much used for ship-building as it was formerly ; it was, in a great measure, superseded by the fir; and latterly larch-wood has been much in use for this purpose. It has also fallen comparatively into disuse for the building of houses and churches; in some old buildings where it yet remains, it has a handsome and venerable appearance. It is styled, both by Chaucer and Spenser, "the builder Oak ;" but the epithet now may be as properly applied to many other trees. The Oak, however, has furnished many superb vessels, and the sailor will still maintain that his ship is " heart of Oak."

Pope thus addresses the Thames: 
"Thou, too, great father of the British floods, With joyful pride survey'st our lofty woods, Where towering oaks their growing honours rear, And future navies on thy shores appear."

Again, he says-

"Let India boast her plants, nor envy we The weeping amber, and the balmy tree, While by our oaks the precious loads are borne, And realms commanded which those trees adorn."

Windsor Forest.

This king of trees has been described by some of our finest poets :

" And to a pleasant grove 1 gan passe, Long er the bright sunne uprisen was :

In which were okes great, streight as a line, Under the which the grasse so freshe of hew, Was newly sprong, and an eight foot or nine Every tree well fro his fellow grew, With branches brode, laden with leves new, That sprongen out agen the sunne-shene, Some very red, and some a glad light green."

Chaucer.

Shakespeare, who ever says a great deal in a few words, has told us how the melancholy Jacques lay along-

"Under an oak, whose antique root peeps out Upon the brook that brawls along this wood."

In a future scene he sends Oliver to give us the remainder of the tree :

"And, mark what object did present itself! Under an oak, whose boughs were mossed with age, And high top bald with dry antiquity, 
A wretched ragged man, o'ergrown with hair, Lay sleeping on his back."

'Twere strange indeed, had Spenser neglected such a tree :

"There grew an aged tree on the green, A goodly oak sometime had it been, With arms full strong, and largely displayed, But of their leaves they were disarrayed: The body big, and mightily pight Throughly rooted, and of wondrous height: Whylom had been the king of the field, And mochel mast to the husband did yield, And with his nuts larded many swine. But now the gray moss marred his rine; His bared boughs were beaten with storms, His top was bald, and wasted with worms, His honor decayed, his braunches sere;

* $\quad * \quad * \quad * \quad * \quad * \quad * \quad * \quad * \quad * \quad *$

For it had been an antient tree, Sacred with many a mystery."

Shepherd's Calendar, February.

Lucan compares Cato in age to a withered Oak :

"Careless of future ills that might betide, No aid he sought to prop his failing side, But on his former fortune much relied. Still seemed he to possess and fill his place; But stood the shadow of what once he was. So, in the field with Ceres' bounty spread, Uprears some ancient oak his reverend head : Chaplets, and sacred gifts his boughs adorn, And spoils of war by mighty heroes worn. But the first vigor of his root now gone, He stands dependent on his weight alone; All bare his naked branches are displayed, And with his lcafless trunk he forms no shade: 
Yet though the winds his ruin daily threat, As every blast would heave him from his seat; Though thousand fairer trees the field supplies, That rich in youthful verdure round him rise, Fixed in his ancient seat, he yields to none, And wears the honours of the grove alone."

Rowe's Lucan, book i.

Cowper's poem of Yardley Oak is too long to insert altogether, yet it will scarcely bear curtailment.

"Survivor sole, and hardly such, of all

That once lived here, my brethren, at my birth, (Since which I number threescore winters past,) A shattered veteran, hollow-trunked, perhaps, As now, and with excoriate forks deform, Relic of ages! could a mind imbued With truth from Heaven, created thing adore, I might with reverence kneel, and worship thee.

Thou wert a bauble once, a cup and ball, Which babes might play with; and the thievish jay, Seeking her food, with ease might have purloined The auburn nut that held thee, swallowing down Thy yet close-folded latitude of boughs, And all thine embryo vastness, at a gulp.

But fate thy growth decreed, autumnal rains Beneath thy parent tree mellowed the soil, Designed thy cradle.

*

two lobes, protruding, paired exact ;

A leaf succeeded, and another leaf, And, all the elements thy puny growth

Fostering propitious, thou becam'st a twig.

Time made thee what thou wast, king of the woods;

And Time hath made thee what thou art, - a cave

For owls to roost in. Once thy spreading boughs

Oerhung the champaign; and the numerous flocks 
That grazed it, stood beneath that ample cope Uncrowded, yet safe sheltered ftom the storm.

While thus through all the stages thou hast pushed Of treeship_first a seedling, hid in grass; Then twig; then sapling, and as century rolled Slow after century, a giant bulk

Of girth enormous, with moss-cushioned root Upheaved abore the soil, and sides embossed With prominent wens globose-till at the last The rottenness, which time is charged to inflict On other mighty ones, found also thee.

Embowelled now, and of thy ancient self Possessing nought but the scooped rind, that seems An huge throat calling to the clouds for drink, Which it would give in rirulets to thy root, Thou temptest none, but rather much forbid'st The feller's toil, which thou could'st ill requite. Yet is thy root sincere, sound as the rock, A quarry oî stout spurs, and knotted fangs, Which, crooked into a thousand whimsies, clasp The stubborn soil, and hold thee still erect.

Thine arms have left thee. Winds have rent them off Long since; and rovers of the forest wild With bow and shaft, have burnt them. Some have left A splintered stump, bleached to a snowy white; And some memorial none where once they grew. Yet life still lingers in thee, and puts forth Proof not contemptible of what she can, Even where death predominates. The spring Finds thee not less alive to her sweet force, Than yonder upstarts of the neighbouring wood, So much thy juniors, who their birth received Half a millenium since the date of thine." 
The Cork-tree, commonly so called, is the corkbarked Oak, Quercus suber. Evelyn tells us it is -called by the Germans Pantoffel-holtz, which signifies slipperwood, because they are in the habit of using the bark for the soles of their shoes; that it was first applied to that purpose by the Grecian ladies, whence they were called light-footed: "from them," continues he, "it is likely the Venetian dames took it up for their monstrous chappines; affecting or usurping an artificial eminency above men which nature had denied them." The poor people in Spain lay broad planks of it by their bedside to tread on, as great persons use Turkey and Persian carpets, to defend them from the floor; and frequently line the walls and inside of their houses built of stone with this bark, which renders them very warm, and corrects the moisture of the air.

The Cork-bark, under the simple name of cork, is known to every one; and it is a very useful substance, as will be admitted even by the little school-boy, who first ventures into the water under its protection, as well as his father, who enjoys his bottle of port after the fatigues of business; or his mother, who, by the adoption of the German fashion, ventures out to market in rainy weather, without fear of wetting her feet. These are among its commonest uses, but they are much more extensive: it is valuable to the collector of insects; and in many places is employed in the construction of beehives. It is true there are some other trees which have a fungous bark that will answer some of the purposes of cork, but none is so good in quality or so plentiful in quantity as that of the Cork-barked Oak. The tree is 
barked every nine or ten years; it has an inner bark, which protects it from the cold; and the removal of the cork or exterior bark is so far from injuring, that it appears to be necessary to the strength and health of the tree. Trees not barked seldom continue in health longer than sixty years; whereas those which are regularly barked will retain their vigour for an hundred and fifty years, or more. The best cork is from the oldest trees; that of very young trees is porous, and of little value; it is however necessary to bark trees of twelve or fifteen years, for the improvement of their bark; this is repeated eight or ten years after; and after these two first peelings, the bark obtained from the tree is in perfection. $1 \mathrm{t}$ is taken off in the month of July. The acorn of this tree is very like that of the Common Oak.

The Cork-tree is a native of the south of Europe, Barbary, \&c. The leaves are not sinuate like those of the Common Oak; they are about two inches long, and one inch and a quarter wide, with a little down on the under side.

"The cork-trees hoar that clothe the shaggy steep."

BYRON.

There are several varieties, of which some shed their leaves in autumn, but the most common are those which are called evergreen: they do not shed them till May, just before the new leaves shoot; but at that time the trees are for a short time nearly bare.

Southey describes the appearance of Cork-trees in the gleam of a traveller's fire : 
"Bright rose the flame replenished; it illumed The cork-tree's furrowed rind, its rifts and swells, And redder scars, - and where its aged boughs O'erbowered the travellers, cast upon the leares A floating, grey, unrealising gleam."

RODERICK. 


\section{PHILLYREA.}

OLEINEE.

DIANDRIA MONOGYNIA.

From Phyllyra, the mother of Chiron: from whom Ovid calls him Phyllyrius.-French, filaria; Italian, lillatro.

There are several species of Phillyrea; natives of the south of Europe: they are evergreen shrubs, and are frequently confounded with the alaternus, a shrub belonging to a different family. They may be readily distinguished by the situation of the leaves, which are alternate in that plant, and opposite in the Phillyrea.

It is chiefly the Broad-leaved, Phillyrea latifolia, which is confused with the alaternus; and as many gardeners call the latter shrub by the name of Phillyrea, for the sake of distinction the former is styled the True Phillyrea. It is a hardy shrub; Evelyn says as hardy as the holly itself. It will sometimes grow as high as twenty feet.

The name of this shrub seems to have been a favourite with gardeners and botanists. It has been observed that some insist on bestowing it upon the alaternus; it also extends to a species of the cassine. Cowley speaks of the evergreen privet by the same title; and Philyra was formerly the appellation of the limetree. 


\title{
PINE TREE.
}

\author{
PINUS.
}

CONIFERE。

MONECIA MONADELFHIA.

French, pin ; Italian, pino.

The Wild Pine Tree, Pinus sylvestris, is commonly called the Scotch Pine, or Scotch Fir, from its plentiful growth in the mountains of Scotland; but it is common in most parts of Europe, particularly the northern parts. The leaves are of a grayish colour, and twisted: the cones are small and pyramidal. In a favourable soil this tree will grow eighty feet high, with a straight trunk : its timber varies in colour, and according to that variation bears the name of white, red, or yellow deal; it is resinous, and durable, and applied to purposes innumerable: the tallest afford masts for our navy. Pitch, tar, turpentine, \&c. is obtained from most of the trees of this genus.

In many parts of the Highlands the roots are dug up, and being divided into small splinters, used instead of candles. Evelyn says this is done in New England also, and in Virginia, and among the Dutch planters in their villages, and that it is there called candlewood. Being somewhat offensive by the quantity of smoke which issues from it, they commonly burn it in the chimney-corner, upon a flat stone or iron; except upon occasions when they want to carry it from one place to another, when they carry a single stick in the hand.

Hard necessity has taught the Kamschatdales and I.aplanders to convert the bark of these trees into bread: 
to effect this, they carefully strip off the outer bark from the finest trees in the spring, and collect the soft white interior bark, which they dry in the shade. When they are ready to use it, they first toast it at the fire, then grind it, and after steeping the flour in warm water to take off the resinous taste, they make it into thin cakes and bake them. Linnæus says that the Swedish boys will often peel off this inner bark, and eat it raw, with a greedy appetite; and that the bark cakes fatten swine. These hard-faring peasants of the north are often reduced to such food, and use the bark of the birch tree for the same purpose.

Lightfoot says that the farina of the flowers is sometimes carried away in such quantities by the winds in the spring, as to alarm the ignorant and superstitious peasants in Scotland with the notion of its raining brimstone.

The Mountain Pine is a variety of this : it is a native of the Swiss mountains, where it is called the Torch Pine. It is very full of resin : the wood is of a reddish colour when fresh cut.

Churchill, in reference to the growth of the Scotch fir, in various soils and situations, says-

"__ the pine of mountain race,

The fir, the Scotch fir, never out of place."

The Pineaster, or Cluster Pine, Pinus pinaster, grows very large, and extends its branches to a considerable distance: the young trees are well clothed, but as they advance in age, the branches have a naked appearance, the leaves are much larger and longer than those of the Scotch Pine, and of a darker green; the cones also are larger. It grows on the mountains of Italy and the 
south of France. In Switzerland it is frequently cut into shingles for the roofs of houses; in the south of France, the young trees are cut for stakes to support vines.

The Weymouth Pine, Pinus strobus, called in North America, its native country, the White Pine tree, is one of the tallest species, often attaining the height of an hundred feet in its native soil. The bark, especially when young, is very smooth and delicate; the leares are long and slender, and close set; the cones long, slender, and very loose, so that if the seeds be not gathered in winter, they open and let them out with the first warmth of spring. The wood is esteemed for masts of ships ; and in the reign of Queen Anne laws were passed for the preservation of these trees, and to encourage their cultivation in America. It is called the Weymouth Pine, and was formerly called Lord Weymouth's Pine, from the first trees of this species in England having been planted in the grounds of Lord Weymouth. It was once called the New England Pine.

The Stone Pine, Pinus pinea, not being so resinous as most of the other species, is but little cultivated for timber: this Pine will grow to a considerable height with a straight stem, and a rough bark; it makes a variety among others of the genus, from the difference of the foliage, both in colour and in its arrangement on the branches. The cones are very large, and make a handsome appearance; and upon close observation, the beautiful arrangement of the scales will be found truly admirable. It is chiefly cultivated for its beauty, and for the kernels of the cones, which, though slightly flaroured with turpentine, are as sweet as almonds. In Italy and the south of France they are frequently served up in 
desserts in the winter season. Sir George Staunton says, too, that they are much relished by the Chinese. They were formerly used here as a medicine, but have been superseded by the almond, of which alone emulsions are now made.

This Pine is a native of the south of Europe; very common in Italy, especially about Ravenna.

The beautiful grove of Pines on Hampstead Heath is said to have been raised from seeds of this species, brought from Ravenna; but if that be the case, the cones vary considerably, from the difference of soil or climate; they bear no comparison with the cones growing in Italy. The following is a beautiful description of the Ravenna Pine :

"Various the trees and passing foliage there,Wild pear, and oak, and dusky juniper, With briony between in trails of white, And ivy, and the suckle's streaky light, And moss warm gleaming with a sudden mark, Like flings of sunshine left upon the bark, And still the pine long-haired, and dark, and tall, In lordly right, predominant o'er all.

Much they admire that old religious tree With shaft above the rest up-shooting free, And shaking, when its dark locks feel the wind, Its wealthy fruit with rough Mosaic rind."

LEIGH HuNT.

The Siberian Stone Pine, Pinus cembra, is lofty and straight; the leaves are very like those of the Pinus pinea, but the cones are longer, and their scales looser. It grows higher up the Alps than any other Pine, even higher than the larch will grow. The timber of this tree 
is soft, and reckoned very fit for the carver. The peasants of the Tyrol, where it abounds, make of it curious carved works, which they dispose of among the common people in Switzerland, who are fond of the resinous smell which exhales from the wood. This Pine is a native of Switzerland and Siberia.

Some botanists make a distinction between the Siberian Stone Pine and the Swiss, saying that the latter is of lower growth, and not so straight, and that the cones are different. The kernels are good to eat, and sometimes form a part of a Swiss dessert; they yield an abundance of oil. The wood is finer grained than deal, more beautifully variegated, and has a pleasing scent. A white odoriferous resin is extracted from it.

Some persons call the Pinus cembra the Evergreen Larch. Harte speaks of the fragrance of this tree; and Mr. Chalmers, in a note upon the passage, says this beautiful tree grows on the Spanish Appennines :

"The cembran pine trees form an awful shade, And their rich balm perfumes the neighbouring glade."

Schmidtmeyer, in his travels into Chili, speaks of a Pine which he met with in the woods of Brazil, the Araucana Pine, of which he says that the cones are as large as a small human head, that the seeds contained in them are like elongated chestnuts, and are sold in the market-places of Rio de Janeiro. He describes the tree as resembling in some degree the silver fir, in its general appearance at some distance; but it must have a different character when near, for, he says, the leaves are more than half an inch broad, and about an inch and a half long, drawn or curled in, and prickly. "The earliest travellers in Paraguay," proceeds he, "and in 
the south of Brazil, describe this tree as growing there to a considerable height and size, affording food to the Indians with its fruits: they call it the Stone Pine, probably from the tree of that name which grows in the south of Spain, and bears nuts also, but different in quality and size*."

Dr. Hunter quotes a passage from Martial, in which he represents it as dangerous to stand under the Stone Pine, on account of the magnitude of its cones :

"Poma sumus Cybeles; procul hine discede, viator, Ne cadat in miserum nostra ruina caput $\uparrow . "$

"High and mighty fruit are we, Apples of great Cybele. Speed thee, traveller, or thy crown Brings the pelting ruin down."

The Pine was sacred to Cybele, who turned Atys into that tree :

"Et succincta comas, hirsutaque vertice pinus; Grata Deuin matri ; siquidem Cybeleius Attis Exuit hac hominem, truncoque induruit illo." Orin, Met. lib. x.

"And that rough tree whose branching foliage nods, Loved by the mighty Mother of the gods, Since youthful Attis, to her fondness blind, Slept in its cone, and hardened in its rind."

Dr. Orger's Ovid.

The Pine is an exceedingly hardy tree, growing upon cold and mountainous places: "It is pretty," says Pliny,

* Travels into Chili, over the Andes, p. 52.

+ The word pomum, in the Latin tongue, is applied to the fruit of all sorts of trees. In English, fir cones are still called fir apples. 
" to consider that those trees that are so much sought after for shipping, should most delight in the highest mountains, as if they fled from the sea on purpose, and were afraid to descend into the water." Dr. Clarke, however, met with pines of a less timid spirit.

"On all sides of the cataract, close to its fall, and high above it, and far below it, and in the midst of the turbulent flood, tall pines waved their shadowy branches, wet with the rising dews. Some of these trees were actually thriving upon naked rocks, from which the dashing foam of the torrent was spreading in wide sheets of spray*."

Travellers tell us, that in the large Pine forests in Norway, \&c. there are frequent fires, which sometimes spread far. (See Fir.) Some have supposed these fires to have been kindled by lightning, but it is very clearly and simply accounted for by the custom the peasants have of throwing out among the trees the contents of an old pipe, which rekindles in the air, and quickly catches these resinous trees.

"Advancing a mile or two," says Dallaway, "we entered a grove of Pine and silver fir, and the greater part having been lately burnt, exhibited a very sombre appearance $\uparrow . "$

A late poet refers to one of these forest fires:

"As the Norway woodman quells, In the depth of piny dells, One light flame among the brakes, While the boundless forest shakes,

* Clarke's 'Travels, vol. iii. p. 181.

+ Dallaway's Constantinople, p. 180. 
And its mighty trunks are torn

By the fire thus lowly born:

The spark beneath his feet is dead;

He starts to see the flames it fed

Howling through the darkened sky

With a myriad tongues victoriously."

Shelley.

Some of the Pines have been celebrated for their use in ship-building. Lucan says--

"From fair Thessalia's Pegasæan shore,

The first bold pine the daring warriors bore,

And taught the sons of earth wide ocean to explore."

$$
\text { Rowe's Lucan, b. vi. }
$$

W. Browne writes-

"The pine with whom men through the ocean renture."

Chaucer speaks of

"The sailing firre ;"

Spenser of

" The sailing pine ;"

And a little farther on, says-

"The firr that weepeth still."

It is curious that in Harte's translation of Statius this distinction is just reversed :

"The advent'rous fir that sails the vast profound, And pine, fresh bleeding from the odorous wound."

The Scotch Pine, which is most in use for shipping, is as frequently called the Scotch Fir, and all the trees of this genus are, more or less, lachrymose. Other firs, 
however, are used in ship-building; indeed most of the trees of this genus.

Sannazaro speaks of " il diritissimo Abete, nato a sostenere pericoli del mare:" - the straight fir tree, formed to sustain the dangers of the sea.

The Pine is particularly noted for its height and straightness. The Faithful Shepherdess, in lamenting the death of her lover, says-

"Ny meat shall be what these wild woods afford, Berries, and chestnuts, plantains, on whose cheeks The sun sits smiling, and the lofty fruit

Pulled from the fair head of the straight-grown pine."

Again, Perigort says to Amoret-

"Oh, you are fairer far Than the chaste blushing morn, or that fair star That guides the wandering seaman o'er the deep, Straighter than straightest pine upon the steep Head of an aged mountain."

"Here also grew the rougher-rinded pine, The great Angoan ships' brave ornament, Whom golden fleece did make an heavenly sign ; Which coveting, with his high top's extent, To make the mountains touch the stars dirine, Decks all the forest with embellishment."

Spexser, Virgil's Gnat.

"Nod the cloud-piercing pines their troubled heads." Wordsworth's Sketches in the Alps.

"On thy white altar we

Lavish in fond idolatry,

Herbs and rich flowers such as the summor uses:

Some that in wheaten fields

Lift their red bells amidst the golden grain : 
Some that the moist earth yields, Beneath the shadows of those pine trees high, Which, branching, shield the far Thessalian plains From the fierce anger of Apollo's eye ;

And some that Delphic swains Pluck by the silver springs of Castaly."

B. Connwall's Worship of Dian.

These straight dark pines have a grand and imposing appearance in the mountainous situations to which they naturally belong. This is frequently noticed by trarellers :

" Tall straight Pines, in rising order, lined the rugged sides, and by their darkening gloom heightened the grandeur of the scene*".

* $\quad * \quad$ * $\quad * \quad * \quad * \quad * \quad * \quad *$

"On looking down, the landscape below was a perfect miniature, to such a height had we attained: the tall pines rising one above another in wild succession under our feet, presented the appearance of a dark-green sea, by the waving of their pliant tops, strongly agitated by the blast that blew around us f."

Mr. Drummond, in his First Steps to Botany, observes, that what is called the needle-leaf of the Pines is necessary to them on account of the northern or Alpine regions they inhabit; for that with any other they could not have been evergreens, "for in winter they would be overpowered with a weight of snow, and blown down by the hurricanes. The acerose leaf enables them to evade both; the snow falls through, and the wind penetrates the interstices. The winds struggling through the boughs

* Brooke's Travels in Norway, \&c. p. 112.

+ Itid.p. 114. 
meet with such innumerable points and edges as, even when gentle, to cause a deep murmur or sighing, and when the breeze is strong, or the storm is abroad, the sounds produced are like the murmuring of the ocean, or the roar of billows among rocks."

"The loud wind through the forest wakes With sound like ocean's roaring, wild and deep, And in yon gloomy pines strange music makes,

Like symphonies unearthly heard in sleep; The sobbing waters dash their waves and weep :

Where moans the blast its dreary path along, The bending firs a mournful cadence keep, And mountain rocks re-echo to the song, As fitful raves the wind, the hills and woods among *."

This murmuring of the winds in the Pine trees has been noticed repeatedly: Lucan compares it to many united roices :

"He said ; the ready legions vow to join Their chief beloved, in every bold design; All lift their well-approving heads on high, And rend with peals of loud applause the sky. Such is the sound when Thracian Boreas spreads His weighty wing o'er Ossa's piny heads : At once the noisy groves are all inclined, And bending roar beneath the sweeping wind: At once their rattling branches all they rear, And drive the leafy clamour through the air. Rowe's Lucan, book i.

Wordsworth describes them as influenced by gentler winds :

"An idle voice the sabbath region fills

Of Deep that calls to Deep across the hills, 
Broke only by the melancholy sound

Of drowsy bells for ever tinkling round;

Faint wail of eagle melting into blue

Beneath the cliffs, and pine-roods' steady sugh *."

Barry Cornwall makes frequent allusions to this poetical language of the woods:

"And when the tempest of November blew The winter trumpet, till its failing breath Went moaning into silence, erery green And loose leaf of the piny boughs did tell Some trembling story of that mountain dell."

Sicilian Story.

Speaking of Polypheme, he says-

๙6 mighty tears then filled

His solitary eye, and with such noise

As the rough winds of autumn make, when they

Pass o'er a forest, and bend down the pines, The giant sighed."

Death of Acis.

66

There dark trees

Funereal, (cypress, yew, and shadowy pine, And spicy cedar), clustered, and at night Shook from their melancholy branches sounds And sighs like death."

And a little farther on-

" and when the rising moon Flames down the arenue of pines, and looks Red and dilated through the evening mists, And chequered as the heary branches sway

* The reader will most probably remember that this word, sugh, so expressive of this whispering of leaves in the wind, is a Scotch word. 
To and fro with the wind, I stay to listen, And fancy to myself that a sad voice, Praying, comes moaning through the leaves, as 'twere For some misdeed."

Marcelia.

This music is celebrated by Moschus in a beautiful little piece translated by L. Hunt :

"But when the deeps are moved, and the waves come Shuddering along, and tumbling into foam, I turn to earth, which trusty seems, and staid, And love to get into a greenwood shade ; In which the pines, although the winds be strong, Can turn the bluster to a sylvan song*."

Mr. Hunt praises the voice of the Pine in an original poem also :

"And then there fled by me a rush of air That stirred up all the other foliage there, Filling the solitude with panting tongues; At which the pines woke up into their songs, Shaking their choral locks; and on the place There fell a shade as on an awe-struck face; And overhead, like a portentous rim Pulled over the wide world, to make all dim, A grave gigantic cloud came hugely uplifting him."

Nymphs $\uparrow . "$

Ovid represents the Cyclops, who lived on the coast of Sicily as carrying a lofty Pine-tree by way of walkingstick; and tells us that Ceres bore a flaming pine, plucked from Mount Etna, in each hand, to assist her

* Hunt's Foliage-Evergreens, p. 78.

+ Ibid. p. 24. 
during the night in the search of her daughter Proserpine.

Orid speaks of the Pine by the name of Teda. Brydone observes, that Teda is still the name of a tree growing on Mount Etna, which produces a great quantity of resin, and was surely the most proper tree that Ceres could have chosen for her purpose *. From the use of the Pine for torchwood, Teda has also been used to signify a torch, and has extended to our own language :

"At which a bushy teade a grcom did light, And sacred lamp in secret chamber hide, Where it should not be quenched day nor night

For fear of eril Fates, but burnen ever bright."

SPENGER.

Homer thus describes the part of the Sicilian coast where the Cyclops dwelt :

"When to the nearest verge of land we drew,

Fast by the sea a lonely care we riew,

High, and with darkening laurels covered o'er;

Where sheep and goats lay slumbering round the shore.

Near this a fence of marble from the rock,

Brown with o'erarching pine, and spreading oak.

A giant shepherd here his flock maintains

Far from the rest, and solitary reigns,

In shelter thick of horrid shade reclined;

And gloomy mischiefs labour in his mind."

Pope's Homer's Odyssey, Book ix.

Sir Philip Sidney gives an inviting description of a wood of Pines:

"They lighted downe in a faire thicke wood, which did entice them with the pleasantnesse of it to take their

* Brydone's Tour through Sicily and Malta, Letter XI. p. 164. 
rest there. It was all of Pine-trees, whose broad heads meeting together, yeelded a perfecte shade to the grounde where their bodies gave a spacious and pleasant room to walke in: they were set in so perfect an order, that every way the eye being full, yet no ways stopped. And even in the middest of them, were many sweet springs, which did loose themselves upon the face of the earth. Here Musidorus drew out such provisions of fruits and other cates, as hee had brought for that daies repaste, and laide it downe upon the faire carpet of the greene grasse. But Pamela had much more pleasure to walke under those trees, making in their barkes pretty knots, that tyed together the names of Musidorus and Pamela, sometimes intermixedly changing them to Pammidorus and Musimela, with twenty other flowers of her travelling fancies, which had bound themselves to a greater restraint than they coulde, without much paine, well endure; and to one tree, more beholding to her than the rest, she entrusted the treasure of her thoughts in these verses*."

As the verses of Sir Philip Sidney are generally the least poetical part of his writings, the reader will not perhaps be anxious to be entrusted with the treasure; let the pine therefore retain its charge. The brilliancy of water seen through the dark shafts of Pine-trees, is beautifully represented in these few lines:

"And midst the flowers, turfed round beneath a shade Of circling pines, a babbiing fountain played, And 'twixt their shafts you saw the water bright, Which through the darksome tops glimmered with showering light." .

Leigh Hunt $\dagger$.

* Sidney's Arcadia. + Story of Rimini, Canto iii. 
Sannazaro speaks of "Pini si grandi, e si spatiosi, che ogn 'un per se havrebbe quasi bastato ad ombrare un selva." Pines so large and spreading, that any one of them might almost have sufficed to shade a wood.

He says that the shadow of the Pine kills every plant that is under it: he alludes perhaps to some particular species; certainly grass will grow luxuriantly under Pines.

A modern writer expresses a similar notion.

Shepherdess. "Help me, drive my sheep Under yon lentisk hedge, while you and I Beneath these shady pines can take our seat."

Shepherd. Here is no turf, and all is rough and deep, With scattered cones that will not let us lie."

H. Sмiтh。 


\section{PISTACIA.}

TEREBINTACEE.

DIOEIA YENTANDRIA.

The derivation of this name is not known.

French, pistachier; Italian, pistacchio.

The Pistacia, or Pistachio-nut tree, called by our old writers the Fisticke-nut tree, is a native of the Levant, where it grows twenty-five or thirty feet high; the bark of the stem, and of the old branches, is russet-coloured, but that of the young branches is of a light brown.

There are three kinds distinguished as different species, which some writers consider only as varieties: the officinatis, the narbonensis, and the vera: in the latter, the leares are composed of two or three pairs of leaflets, terminated by an odd one; they are nearly egg-shaped, and turn back at the edges. The leares of the $P$. officinalis, or Common Pistacia, have generally three, but sometimes four leaflets, of a dark green colour; the P. Narbonensis has three or five roundish leaflets, of a light green.

In all these, the leaves, when bruised, emit an odour like that of the nut itself.

Although one of these species has been named Narbonensis, and Linnæus affirms that the Common Pistacia is a native of Sicily, they are generally supposed to have been brought to Europe originally from the East. Pliny says that the Emperor Vitellius introduced the Pistacia into Italy from Syria, when he was legate in that prorince $*$.

* See Martyn's Miller. 
The Pistacia tree was cultivated in England in 15\%0. It flowers in April and May. It produces its nuts in this country; but our summers are not warm enough to ripen them. In the Levant, the nut ripens in September. The kernel is of a pale green colour, sweet, and not unpleasant to the taste; it is covered with a gray, or more commonly a red skin, and enclosed within a double shell, of which the outermost is dry, membraneous, and red; the inner, brittle, smooth, and white.

These nuts, taken in wine, were supposed in old times to be a preservative against the bite of all manner of wild beasts. It is probably to this notion Cowley refers in the following couplet:

"The firm pistachio next appeared in view,

Proud of her fruit, that serpents can subdue."

Plants, book 5.

The reader will remember the lamb fed with pistachio nuts, which formed a part of the Barmecide's feast.

An oil is extracted from the nut of the Pistacia vera, which, having neither taste nor smell, is used in the East as a menstruum for the extraction of the perfume of flowers, as jasmines, roses, \&c.

The Pistacia terebinthus, or Common Turpentine tree, French, Terebinthe; Italian, Terebinto, is a native of Barbary and the south of Europe; it has been cultivated here since 1730, and flowers in June and July. Cyprus, or Chio turpentine is obtained from this tree, by wounding the bark in several places in the month of July. A space of about three inches is left between the wounds; from these the turpentine drops upon stones placed underneath, upon which it becomes so much condensed by the coldness of the night, as to admit of being scraped off with a knife, which is always 
done before sunrise. In order to free it from all extraneous matter, it is again liquified by the sun's heat, and passed through a strainer; it is then fit for use. The quantity produced is very small, a large tree yielding little better than a pound or eighteen ounces. In the eastern part of the islands, the trees afford somewhat more, but still so little as to render it very costly, and on this account it is generally adulterated.

Tournefort says, the peasants of Chios gather it from the flat stones placed under the trees to receive it, by means of little sticks, from which they drop it into bottles; and that they sell at thirty or thirty-five parats the oque*.

"The island," he says, "furnishes but three hundred oques.$+ "$

The best Chio turpentine is about the consistence of thick honey; very tenacious, clear, and almost transparent. It is of a yellowish white; the smell is fragrant, it is moderately warm to the taste, and entirely free from acrimony and bitterness.

According to Dr. Geddes and other learned writers, the turpentine tree is frequently mentioned in the old Testament, where the translators have rendered it incorrectly: in some cases it has been made to signify an oak $\ddagger$, sometimes a plane $\S, \& c$. Dr. Geddes expresses a doubt whether the original word ever signifies a plane, "whereas," continues he, "it certainly signifies a tree of some sort or other; and it is my fixed opinion, that it

* An oque weighs three pounds and nine ounces.

+ Tournefort's Levant, vol. ii. p. 70.

*. See Genesis, chap. xxxv. 4; Joshua, chap. xxiv. 26.

$\S$ Genesis, chap. xii. 6. 
is that species called terebinthus, which lives to a very great age; and seems to have been held in as great veneration in the East, as the common oak was among the Greeks, Romans, Germans, Gauls, and Britons."

The Pistacia lentiscus, or Common Mastick tree, French, Lentisque; Italian, Sondro, is a native of the Levant and the south of Europe: it grows about eighteen or twenty feet high; the trunk is covered with a gray bark; it sends out many branches, of which the bark is of a reddish-brown colour; the leaves are composed of three or four pairs of small leaflets, of a lucid green on their upper, but pale on their under side; the mid-rib, or common foot-stalk, has two narrow borders or wings running from one leaflet to another. The fruit is small, and black when ripe; it has a stone in the middle, which contains a white kernel; and from these kernels an oil is extracted, fit both for the lamp and the table.

This tree is chiefly valuable for the resinous substance obtained from it, called gum mastick. In the isle of Chios, the gathering of mastiok usually begins on the first of August. Incisions are made in several parts of the bark of the trunk with large knives; the next morning the resin is seen to distil from these incisions in small tears, which are suffered to fall to the ground, and hardening there become grains of mastick; they are about the size of pearl barley, yellow, slightly transparent, and brittle. The ground is carefully swept under the trees; and this gathering is generally continued till the middle of August, provided the weather be dry. Towards the end of September, the resin again exudes from the same incisions, but in much smaller quantities than before. The grains are sifted to separate them 
from all extraneous matter; and the dust which flies from them adheres so strongly to the faces of those who work at it, that they are obliged to wash their faces with oil. Mastick is consumed chiefly by the ladies of the seraglio, who masticate it, not only to sweeten the breath, but also to strengthen the gums and to whiten the teeth. They put a few grains of it into their perfuming pans, and into the bread before it goes into the oven.

The Grand Seignior has a claim upon all the mastick trees cultivated by his subjects; and the trees cannot be sold but upon condition that the same portion shall be paid by the purchaser as was paid by the former owner. Sometimes an aga is sent from Constantinople to receive the mastick due to the Grand Seignior; sometimes this is done by the officers of the custom-house of Chios. An officer goes into three or four of the principal villages, and gives notice to the inhabitants to bring in their respective portions. All the villages together pay two hundred and eighty-six chests of mastick, weighing each a hundred and twenty-five oques. The cadi of Chios receives three chests, each weighing eighty oques: a chest goes to the clerk of the villages, who keeps the registers of the persons who pay the mastick; and the custom-house officer who weighs it takes a handful from each chest, for his own portion.

If any one is surprised carrying mastick to the city, or to those villages where it is not cultivated, he is condemned to the galleys, and his goods are confiscated. The peasants who do not gather mastick enough to pay the required portion, buy or borrow it of their neighbours; and those who have more than enough, either sell it secretly, or save it for the following year. Some- 
times they agree with the custom-house officer, who consents to take it of them at a certain price, and sells it again, with a profit of a hundred, or a hundred and fifty per cent.

The Greeks who cultivate mastick pay but half of the capitation, or poll-tax, and wear a white linen band round their turbans, like the Turks.

In former times, mastick was supposed to be a remedy for a variety of diseases and accidents both real and imaginary. Among other uses, it was considered as powerfully exciting the appetite. Infused in rose-water, Gerarde tells us it is excellent to wash the mouth with to fasten loose teeth, "and to comfort the jaws." He tells us, too, that, spread upon a piece of leather or velvet, and laid on the temples as a plaster, it relieves pains of the jaws and teeth. At present it is scarce ever used as a medicine, but enters as an ingredient into many kinds of varnish. It is also used by the apothecaries and druggists, when dissolved in spirit of wine, to give a milky appearance to spirit of sal ammoniac, ayua ammonice purce, previously scented with different oils, as those of lavender, rosemary, or amber, to which is sometimes added musk. This compound is sold by the French name of eau de luce, as an agreeable perfume; but the original eau de luce véritable is scented with the unrectified fetid oil of amber only, and has of course a disagreeable odour, being intended as a medicine in hysteric fits. Some use Chio turpentine instead of mastick to give this milky appearance.

The wood of this tree yields an aromatic smell in burning. Evelyn recommends it as making "the best tooth-pickers in the world;" and Dr. Hunter quotes an epigram from Martial, giving it the same character : 
"Lentiscum melius; sed si tibi frondea cuspis Defuerit, dentes penna levare potest.

L. xiv. Ep. 22.

"Lentisk is best, but if you've none, why then E'en take a pen."

An excrescence is found among the leaves of the turpentine and mastick trees, which is produced by the puncture of an insect, and when opened is found full of little worms.

The Lentiscus is considered a beautiful evergreen, but it is rather tender. In this climate, the Pistacia nut and the turpentine trees both require a warm situation: they are generally planted against a warm wall, where our common winters will not injure them. In very severe winters, they have some little protection, but the Lentiscus requires some shelter in seasons less serere. It was cultivated in this country in 1664. It blossoms in May.

There is, in Barbary, another species of Pistacia which yields mastick, though of an inferior kind, Pistacia Atlantica. It is not, however, readily distinguished from the oriental mastick, and both bear the same name among the Moors, Heulc. The Arabs collect this gum, and make the same use of it as of the mastick from Chios. The fruit of this tree is eaten by the Moors, who sometimes bruise it and mix it with their dates. 


\section{PLANE TREE。}

PLATANUS.

Platanus is supposed to be derived from a Greek word signifying wide; in reference either to the broad leaves, or spreading branches of the tree. French, platane; Italian, platano.

The Eastern Plane-tree, Platanus Orientalis, is a native of Asia, where it grows very large : the stem is tall, erect, and corered with a smooth bark, which annually falls off in scales. The ieaves are alternate, about seven inches long, and eight broad, deeply cut into five segments, and the two outer ones again slightly cut in the middle: the segments have many acute indentures on their borciers, and have each a strong midrib, with many lateral veins. The upper side of the leaf is a deep green, the under side paler: the flowers are so small as scarcely to be distinguished one from the other without glasses; they grow upon long-foot stalks, hanging downwards, in balls, four or five together ; some of the larger balls are four inches in circumference. They blow late in May, or early in June, a little before the leaves come out. If the seeds are left upon the trees, they will remain till spring, when they will fall off, the balls dropping to pieces; and the wind will often carry these seeds (which are surrounded with a bristly down) to a great distance.

The size of the Plane varies much in different countries: in Persia there are some of these trees four yards 
in circumference, whereas on Mount Caucasus it takes the appearance of a large shrub; as does the American Plane in the gardens at St. Petersburgh.

The Plane is highly esteemed for its beruty and shade. It is said to have been brought from Asia first, for the purpose of making a monument to Diomedes; then to have passed into Sicily, and from thence spread over Europe. It was in great favour with the Romans; they planted it near their houses, and in long avenues to walk in, and even nourished it with wine. Pliny remarks that there is no tree whatsoever that so well defends us from the heat of the sun, or that admits it more kindly in winter; for the branches being at a distance proportionable to the size of the leaves, when they have fallen, the branches easily admit the rays of the sun. This observation, as Martyn observes, holds good with all trees; nevertheless some trees more clothed than others will better shut out the summer sun. Spenser describes a shady grove

" Whose lofty trees, yclad with summer's pride, Did spread so broad, they heaven's light did hide, Nor perceable with power of any star."

Whatever Pliny or Spenser may think upon this subject, Sannazaro pronounces it a want of courtesy entirely to shut out the sun:

"Ne sono le dette piante si discortesi, che del tutto con le loro ombre vietino i raggi del sole entrare nel dilettoso boschetto, anzi per diverse parti si gratiosamente gli ricevono, che rara è quella herbetta, che da quelli non prenda grandissima recreatione, e come che d'ogni tempo piacevole estanza vi sia, ne la fiorita primavero piu che in tutto il restante anno piacevolissima vi si ritrova." 
"These plants are not so discourteous as entirely to shut out the rays of the sun from this delightful grove, but in various parts graciously received them, so that there was scarcely a spot of grass that did not take pleasure in them; and this retreat is at all times beautiful, though more lovely in the flowery spring than in any other season."

Evelyn supposes this tree to have been introduced here by Lord Bacon, who had a fine plantation of them at Verulam; but this Mr. Martyn has proved to be a mistake, since, according to Turner's Herbal, it was cultivated here as early as 1562, but one year after Lord Bacon was born. Heallows, however, that the plantations at Verulam might be the first of any note or consideration.

With us it is considered merely as an ornamental tree, and as affording an agreeable shade; but it is recorded that the Turks formerly built their ships with its timber. It is rather late in producing its leaves, and too quick in parting with them.

Pausanias mentions a tree of extraordinary size and beauty in Arcadia, supposed to have been planted by Menelaus. If this were the case, the tree must have been thirteen hundred years old; and it is thought a Plane tree of that age could not be in a state of vigour and beauty.

It is said that the Plane was held sacred to Helen, the wife of Menelaus.

Pliny mentions a Plane tree in Lycia, which mouldered away into an immense cave, eighty feet round. Licinius Mutianus, governor of that province, with eighteen others, dined commodiously on the benches of pumice placed round the body of it. He speaks of another that belonged to Caligula, growing at his villa, near Velitræ, the hollow trunk of which held fifteen persons at dinner, 
with their proper suite of attendants. Evelyn gives a curious account of the adoration Xerxes is said to have paid to a Plane tree.

"6 This beautiful and precious tree, anciently sacred to Helena (and with which she crowned the lar and genius of the place), was so doted on by Xerxes, that AElian and other authors tell us he made halt, and stopped his prodigious army of $1, \% 00,000$ soldiers, which even covered the sea, exhausted rivers, and thrust Mount Athos from the continent, to admire the pulchritude and procerity of one of them; and became so fond of it, that spoiling both himself, his concubines, and great persons of all their jewels, he covered it with gold, gems, necklaces, scarfs, bracelets, and infinite riches. In sum, was so enamoured of it, that for some days neither the concernment of his grand expedition, nor interest of honour, nor the necessary motion of his portentous army, could persuade him from it: he styled it his mistress, his minion, his goddess; and when he was forced to part from it, he caused the figure of it to be stamped on a medal of gold, which he continually wore about him."

He tells us that the Romans first brought it out of the Levant, "6 and cultivated it with so much care and industry for their proud and stately heads, that the great orators and statesmen, Cicero and Hortensius, would exchange now and then a turn at the bar, that they might have the pleasure to step to their villas, and refresh their Platans, which they would often irrigate with wine instead of water."

In another passage, he says that when this tree was removed into France, a tribute was exacted of any person who should presume to put his head under it; and that he had been informed by a worthy knight, that since the 
number of Planes had been increased about Ispahan, in Persia, the plague had not come near the place.

"In the school of Plato," says Dr. Hunter, "6 the philosophers used to walk and converse together under the shade of these delightful trees."

"And broad-leaved plane trees in long colonnades

O'erarched delightful walks,

Where round their trunks the thousand-tendrill'd vine

Wound up, and hung the boughs with greener wreaths, And clusters not their own."

Southey's Thalaba.

Ovid calls it the genial Plane, "platanus genialis."Sannazaro uses a similar epithet : "amenissimo piatano." The Greeks seem to have liked it as well as the Romans. Moschus says-

"I love a sleep under a leafiy plane*"

One of our English poets gives good reason for such a taste :

"The heavy-headed plane tree, by whose share The grape grows thickest, men are fresher made."

W. BROWNE。

Moore speaks of it by its Persian name of Chenar tree :

"While some, for war's more terrible attacks, Wield the huge mace and ponderous battle-axe; And as they wave aloft in morning's beam The milk-white plumage of their helms, they seem

* Hunt's Foliage, Evergreens, p. 78. 
Like a chenar tree grove, when winter throws

O'er all its tufted heads his feathering snows *."

He gives a quotation from Forster, in which that author says there are numerous small islands rising from the Lake of Cashmere, and that one is called Char Chenaur, from the Plane trees upon it.

"Though sunny the lake of cool Cashmere, With its plane tree isle reflected clear t."

"6 'The Chenar is a delightful tree; its bole has a fine white and smooth bark; and its foliage, which grows in a tuft at the summit, is of a bright green+."

'The American Plane tree, Platanus Occidentalis, is called by the English Americans Button-wood, or Waterbeech : it is remarkable for its quick growth. There are such numbers of them in the low meadows between Philadelphia and the ferry of Gloucester, that in summer it is a shady walk all the way.

'Ihis Plane was introduced here early in the seventeenth century. Johnson, in his edition of Gerarde's Herbal, in 1633, mentions two young ones at that time growing in the garden of Mr. Tradescant. It does not bear the severer frosts of this country; in that of 1812 the greater number of the Planes in England perished.

* Veiled Prophet of Khorassan.

\& Moore's Paradise and the Peri. $\quad$ \% Morier's Travels. 


\title{
POMEGRANATE TREE.
}

\author{
PUNICA GRANATUM.
}

MYRTEE. ICOSANDRIA MONOGYNIA.

French, grenadier; Italian, melagrano, pomogranato.

The Common Pomegranate tree grows eighteen or twenty feet high, sending out branches all the way, which also are garnished with many slender twigs, making it altogether very thick and bushy. The leaves are about three inches long, and half an inch broad in the middle, drawing to a point at each end; they are of a lucid green, and opposite in pairs. The flowers are of the most brilliant scarlet colour, and it is chiefly on their account that the tree is cultivated in English nurseries, for the fruit seldom comes to perfection in this country. The Double-flowered variety is therefore the most desirable, and this is often covered with its large beautiful scarlet blossoms for two or three months.

It is a native of Spain, Portugal, Italy, Barbary, Persia, Japan, China, \&c. In the West Indies, where it is supposed to have been introduced from Europe, the fruit is larger, and better flaroured than elsewhere.

The Dwarf Pomegranate, Punica nana, is a native of the West Indies, and requires a green-house, winter and summer, in this country.

We no sooner cut open a Pomegranate, than we perceive how descriptively appropriate is the name-Pomegranate, seeded fruit; and so beautiful are these scarlet 
grains, bathing and sparkling in their own wine, that it seems a pity to destroy so much beauty; though we do not long hesitate, particularly on a summer's day.

Andrew Marvell, referring the beauties of a garden to the benevolent Deity, by whom they were given to mankind, says-

"He hangs in shades the orange bright,

Like golden lamps in a green night;

And does in the pomegranate close

Jewels more rich than Ormus shows."

Yet Thomson, comparing it with the palm, the cedar, and the vine, mentions it with a comparative disrespect:

"Give me to drain the cocoa's milky bowl, And from the palm to draw its freshening wine, More bounteous far than all the frantic juice Which Bacchus pours. Nor, on its slender twigs Low-bending, be the full pomegranate scorned."

There may, indeed, be reasons for scorning, or rather for shunning this fine fruit, when we consider that it is one of the fair temptations of the garden of Pluto. The reader will remember the disappointment of Ceres, who after long search of her lost daughter Proserpine, having learned that she had been conveyed by Pluto to the shores of Styx, hastens to implore aid of Jove, the father of Proserpine, who tells her that

"On one condition she may yet elude Her spouse, her lips must ne'er have tasted food; So will the fates."

Ceres flies eagerly to recover her child, when Ascalaphus, a mischievous prying Acheronian. betrays the 
fact that the young beauty, when wandering in Pluto's garden, plucked

"A ripe pomegranate, from whose pallid core

To her red lips seven seeds the damsel bore."

Proserpine returned the civilities of her babbling foe by transforming him to an owl, and poor Ceres was compelled to accept of Pluto for a son-in-law.

Harte compares its blossom to the rose:

"The punic-granate opes its rose-like flowers."

And Lord Byron promotes it to the rose's dwellingplace:

" On her fair cheek's unfading hue

The young pomegranate's blossoins strew

Their bloom, in blushes ever new."

Rapin compares the interior of the fruit to a honeycomb :

"Succeeding fruits attend the blossom's fali, Each represents a crown upon a ball;

A thousand seeds with Tyrian scarlet dyed, And ranged by Nature's art in cells they hide.

As when industrious bees, with frugal care, A waxen kingdom for their stock prepare, On twigs first lay foundations for their combs, Then mark the shining fabric into rooms:

For every seed his cell and order holds, Whilst a thick rind the juicy fruit enfolds : Grateful to taste, their mingled flavours meet, Nor rudely sharp nor yet too luscious sweet."

Rapin proceeds to tell a story of the origin of this fruit, which was formerly, he says, an ambitious beauty, who being anxious to learn her future destiny, was an- 
swered by the priest, that she should wear a crown and the regal purple: but all her royalty ineant no more than the figure and colour of the Pomegranate, into which she was transformed by Bacchus :

"Pomegranates full

Of melting sweetness."

T. MOORE.

Chaucer mentions this fruit as grateful to the sick:

"There were, and that wote I full wele,

Of pomegranettes a full great dele,

That is a fruit full well to like,

Namely to folke when they ben sike."

Romance of the Rose.

The Pomegranate appears to have been highly esteemed by the children of Israel; it was held out as one of the great blessings of the land of promise, that this fruit grew there. They quarrelled with Moses, that he brought them to a place where they could not find grapes, figs, and pomegranates; and when he sent the elders of the different tribes to examine the land of Canaan, and see what it yielded, they brought to him from Eshcol these three fruits*.

They adorned the robe of the high-priest with Pomegranates :

"And upon the hem of it thou shalt make pomegranates of blue, and of purple, and of scarlet, round about the hem thereof; and bells of gold between them round about.

"A golden bell and a pomegranate, a golden bell and a pomegranate upon the hem of the robe round about."

Exodus, xxviii. 33, 34 .

* See Numbers xiii. 23 ; xx. 5 ; Deut. viii. 8. 
The Canticles speak of the wine of Pomegranates; and according to Sir John Chardin, considerable quantities of wine are still made of the juice of Pomegranates, in the East, particularly in Persia*. The Turks about Aleppo frequently flavour their wine with the juice of this fine fruit $\dagger$.

* See Harris's Nat. Hist. of the Bible, p. 314.

+ Russell's Nat. Hist. of Aleppo, p. 107. 


\title{
POPLAR TREE.
}

\author{
POPULUS.
}

SALICINEE.

DIECIA OCTANDRIA.

French, peuplier ; Italian, pioppo.

The White Poplar, Populus alba, in Italian, Gattico, grows very tall, with a straight trunk, and a smooth pale bark; the leaves are of a dead green above, but underneath white and downy; they are about three inches long, on a footstalk of about an inch, flattened, and grooved on each side.

It is a native of Europe, from Sweden to Italy, of Siberia and Barbary; it grows in woods and hedges, and takes delight in the neighbourhoods of rivers and brooks. There is a variety of this, called the Great White Poplar, or Abele tree, of which the leaves are nearly twice the size, and are less round in figure; the young shoots are of a paler colour, and its growth is much quicker. The finest of these trees are natives of Holland and Flanders, and are called by some the Dutch Beech.

Hartlib, in his Compleat Husbandman (1659), says that, some years ago, ten thousand Abeles were brought from Flanders at one time, and transplanted into several English counties. "This timber," says he, " is incomparable for all sorts of wooden vessels, especially trays, 
and butcher's trays cannot well be made without it, being so exceeding light and tough."

Evelyn, speaking of the quick growth of this tree, says, "A specimen of this advance we have had of an Abele tree, at Sion, which being lopped in February, 1651, did, by the end of October, 1652, produce branches as big as a man's wrist, and seventeen feet in height."

He tells us that Sir Richard Weston made a plantation of them near Richmond, calculating that thirty pounds laid out in this way would, in eighteen years, return at least ten thousand.

The Dutch consider a plantation of them as an ample portion for a daughter.

Martyn says, that floors which he had seen, made of planks of the Abele, were extremely beautiful.

"The wood of the White Poplar," says Evelyn, " is sought of the sculptor. In sword and buckler days, they made shields of this material : it is soft, white, and stringy, and makes good wainscotting, being little subject to swell, or shrink."

The Black Poplar, Populus nigra, has a long naked trunk, and a handsome regular head; the bark is ashcoloured : the leaves are smooth on both sides, of a light green colour, and slightly notched at their edges. It is of quick growth, and in moist situations will rise to a great height, throwing out innumerable suckers from the roots. The bark being light, like cork, serves to support the nets of fishermen. The wood is light, soft, and not apt to splinter; is used by the turner, and in particular by the bellows-maker, being very close, yet light. It is considered as excellent for flooring, on account of its 
slowness in taking fire, which is such, that it is said that the flames of a house on fire were stopped when they came to that part where this timber had been used. It smokes long before it flames, and is consequently a bad fuel.

Brooms are made of the twigs, and in some places sheep are fed upon the dried leaves in winter.

The foliage of this tree is of a glittering brightness, and its shade is esteemed wholesome. It will flourish in almost any soil, and the large thick leaves, full of juice, which fall in such abundance in the autumn, are thought to improve the ground they grow in: thus tracts of waste land, not dry, may in a few years be rendered fertile.

In Kamschatka, the poor natives are sometimes reduced to the necessity of making bread from the inner bark of this tree, as they do also of the fir, and as the peasants of Norway do both of that and the birch. Paper has been made from the cottony down of the seeds. In Flanders a prodigious quantity of shoes are made of Poplar wood, with which they supnly all Holland. The Black Poplar grows in the same countries as the White.

The Lombardy, Turin, or Po Poplar, Populus di'atata, differs from the Black, chiefy in its close conical growth, in which it much resembles the cypress: the leaves too are broader than they are long, whereas those of the Black Poplar are the reverse. Some persons consider it only as a variety of that species. The wood of this tree is used for packing dry goods, as bales of woollen ; and for folding pieces of silk upon ; its lightness saving much expense in carriage. In Lombardy the 
carts in which the grapes are carried from the vineyard, are of these planks, cut about two inches thick, and in them the grapes are squeezed.

In Essex this tree is called the Rochford, because it is said to have been first introduced into this country by the Earl of Rochford, who planted some in that county about the year 1758 .

The Tacamahaca Poplar, Poputus balsamifera, is a native of Canada, and some other parts of North America, and of Siberia. The scaly coverings of the buds abound with a tenacious balsam in the spring, which becomes liquid by exposure to the sun; it is yellow, and has a fragrant scent.

From Canada this tree was taken to the Isle of Jersey, from whence six of the plants were sent to Caroline, the Queen of George the Second, in 1731, by the name of Arbre de la Reine. One of these was given by the Queen to Sir Hans Sloane, and was planted in the Botanic Garden at Chelsea.

It is said that grouse, and other birds of that family, acquire a fine flavour by feeding on the buds during the winter in Siberia.

There are several American Poplars: the Carolina Poplar, Populus angulata, has very strong shoots, which are generally sharply cornered, and covered with a light green bark: as they advance in age, the bark becomes of a pale gray colour. It is a large tree in Carolina : it was cultivated in England in 1759 by Mr. Miller.

The Athenian Poplar, Populus Graca, was brought to England by Hugh, Duke of Northumberland, in 1779 .

The aspen has been noticed by that name.

The Poplar is well known as being sacred to Hercules: 
"The poplar to Alcides consecrate."

He crowned his head with it from the banks of Acheron, when he returned from the infernal regions; His crown was of the White Poplar:

"The poplar that with silver lines his leaf."

In Virgil's ninth Eclogue, the shepherd inviting Galatea, mentions, among other recommendations, that the White Poplar grows near his dwelling:

" _ - hic candida populus antro

Imminet, et lentæ texunt umbracula vites."

"Near to my grot the silver poplar grows, Its shade inwoven with the leafy vine."

When any ceremonies or sacrifices were performed to Hercules, his worshippers wreathed their heads with the leaves and young shoots of this Poplar :

" Tum Salii ad cantus, incensa altaria circum, Populeis adsunt evincti tempora ramis :"

Eneid, viii.

Translated by Dryden-

"The Salii sing, and cense his altars round

With Sabine smoke, their heads with poplar bound."

The poets tell us that the Heliades, on account of their great affliction at the death of their brother Phaeton, were changed into Poplars, their tears being converted into amber. They do not, indeed, altogether agree upon this subject: Ovid only says they were changed to trees; and this having happened on the banks of the Po, he has been supposed to mean poplars, with which those banks are covered. 
Some have conferred this honour upon the larch; but if there be a doubt, it lies between the Poplar and the alder.

Sannazaro tells us this illustrious origin belongs to the Poplar: our countryman Cowley attributes it to the alder :

"The Phaetonian alder next took place,

Still sensible of the burnt youth's disgrace;

She loves the purling streams, and often laves

Beneath the floods, and wantons with the waves."

Book v.

Rapin is for the Poplar :

"Nor must the Heliad's fate in silence pass, Whose sorrow first produced the poplar race;

Their tears, while at a brother's grave they mourn,

To golden drops of fragrant amber turn."

Book ii.

Still more to add confusion to sylvan genealogy, Virgil, who (his birth being the most ancient) was most likely to know the truth of the affair, takes both sides of the question : in the sixth Eclogue, he says-

"Tum Phaëthontiadas musco circumdat amaræ Corticis, atque solo proceras erigit alnos."

Rendered by Dryden-

"The sisters mourning for their brother's loss ; Their bodies hid in barks, and furred with moss, How each a rising alder now appears, And o'er the Po distils her gummy tears."

In the tenth Eneid- 
"Namque ferunt, luctu Cycnum Phaëthontis amati, Populeas inter frondes umbramque sororum Dum canit, et mœstum Musa solatur amorem."

"For Cycnus loved unhappy Phaeton, And sung his loss in poplar groves, alone, Beneath the sister shades to soothe his grief."

DRYDEN's Virgil.

Spenser alludes to the circumstance, without naming the tree :

"And eke those trees in whose transformed hue, The sun's sad daughters wailed the rash decay Of Phaeton, whose limbs with lightning rent, They gathering up, with sweet tears did lament."

It is pretty generally understood, however, to be the Poplar tree that is so nearly related to the sun; and the Black Poplar : and it is certain that there is no tree upon which the sun shines more brightly.

The Lombardy Poplar also has its own peculiar merits, as well as the White and the Black : all the Poplars, indeed, have an elegant effect when mingled with trees of broader growth :

"Gracing each other like the trees in spring, The tufted by the tall."

But that of Lombardy has this great and peculiar beauty, that its fine spiral form, when agitated by the wind, moves in one sweep from the top to the bottom, forming a beautiful waving line, which Martyn aptly compares to an ostrich feather waving on a lady's head. All the branches, as he observes, coincide in the motion, and the least breeze will stir it, when other trees are at 
rest. This circumstance has been noticed by one of our living poets :

"And there the alder was with its bright green, And the broad chesnut, and the poplar's shoot, Thar like a feather waves from head to foot."

LEIGH Hun's.

The following lively picture we may suppose to design the Black Poplar, as that which most reflects the sunshine :

"___ The poplar there

Shoots up its spire, and shakes its leaves i' the sun

Fantastical, while round its slender base

Rambles the sweet-breathed woodbine."

B. Cornwall。

Here we have the White Poplar:

"The greenwoods moved, and the light poplar shook

Its silver pyramid of leaves."

B. Cornwall.

In the Odyssey, the busy motion of the Poplar leaves is compared to that of a woman's fingers when spinning :

"Full fifty handmaids form the household train,

Some turn the mill, or sift the golden grain;

Some ply the loom; their busy fingers move

Like poplar leaves when Zephyr fans the grove."

Book vii.

Garcilasso, the Spanish poet, likens it to a lady's hair, playing in the wind:

"Each wind that breathes, gallantly here and there

Waves the fine gold of her disordered hair,

As a green poplar leaf in wanton play

Dances for joy at rosy break of day."

WIFFEN's Garcilasso. 
It has been observed, that the Poplar is not dainty as to soil: it will grow in any but a very dry soil, but it most delights to coast the rills and brooks;

"The poplar trembling o'er the silver flood,"

will grow more luxuriantly than in a wood, or park, where it has no water near:

"The poplar never dry,"

says Spenser. The following is a beautiful miniature:

"It was a shallow dell, set in a mound Of sloping shrubs, that mounted by degrees, The birch and poplar mixed with heavier trees; From under which, sent through a marble spout, Betwixt the dark wet green a rill gushed out, Whose low sweet talking seemed as if it said Something eternal to that happy shade.'

Leigh Hunt.

Cowper has addressed some verses to a field of Poplars under which he had been accustomed to sit, which were afterwards felled, much to the poet's regret. 


\title{
PSEUDO-ACACIA.
}

\author{
ROBINIA.
}

This tree is commonly called simply, the Acacia. French, robinier, caragan; Italian, caragana.

The foliage of the Robinia Pseudacacia, or Locust tree, is of a singularly beautiful green, the blossoms peashaped and white (except that which, from the colour of the blossom, is styled the Rose Acacia), and droop like the flowers of the Laburnum. They are very elegant, but of so short duration, that they are scarcely in beauty so long as a week. They blow in June, are very numerous, and sweet-scented. These are succeeded by an oblong pod, which, in mild seasons, will ripen in this country, but not till late in the autumn.

In a farourable soil, this tree has been known to shoot six feet in one year; and, being well furnished with leaves, it is very handsome while young; but if it is exposed to high winds, it is apt to be torn by them, and then it makes rather an unsightly appearance as it advances in age.

Evelyn says, that both these Acacias are apt to exhaust the soil; and another circumstance which renders the Robinia less desirable than otherwise it would be, is, that they do not put out their leaves till late in the spring, yet shed them early in the autumn. 
Extraordinary things have been said of the value and duration of the wood of the Robinia. Evelyn quotes the opinion of a shipwright who was sent over to Virginia to build two large ships, and used often to say that, if a sufficient quantity could be had, it would be the best timber he had ever met with for building of ships. This man, after completing his engagements with his employers, built a vessel for himself, and not having the iron necessary for some important parts of it, had recourse to the hazardous experiment of substituting the wood of the Locust tree. When he arrived in Liverpool, he thought it prudent to remove this wood from some parts, and replace it with iron, but it was found in very excellent cordition. The parts for which it was used were what the shipwrights term trenails, a kind of wooden pins, generally used in building vessels; but, in this case, they suppied the place of iron bolts. This wood has since been used frequentily for trenails, and found superior to the best oak in strength and duration; but it is sufficiently plentiful to be used for other parts of ships.

The leares afford an excellent and grateful fodder to cattle; and its cultivation has been much encouraged for this pu:pose in New England, where the grass is frequently dried up by summer droughts. 


\section{PYRACANTHA.}

\section{CRAT AGUS PYRACANTHA.}

POMACE压.

ICOSANDRIA DIGYNIA,

French, buisson ardent.

The Pyracantha is a species of the Mespilus, placed apart only because it is best known by its specific name. Some call it the Evergreen 'Thorn, a name common to many shrubs; and it was formerly known by the appellation of the Prickly Coral. The great beauty of this shrub is its fruit; the glossy bunches of beautiful scarlet berries, with which it is covered in the winter. It is generally trained against a wall, that these berries may be seen to greater advantage; and on a white, or palecoloured wall, the bunches of red berries, intermingled with the green leaves, form a fine and pleasing contrast. The leaves fall only as the new ones dispossess them. The blossoms are white and small.

The Pyracantha is a native of the south of Europe, and very abundant on Mount Caucasus, and in China. It was cultivated in England in 1629: with us it flowers in May. The berries are eaten by birds.

66. Phillyrea here and pyracantha spread

Their verdant foliage, and berries red,

In glowing clusters; beauteous food; unmeet

For man, but to the welcome birds most sweet; And every song that made their summer merry

The shrubs repay in winter with a berry."

Cowley, book vi. 


\title{
SERVICE TREE.
}

\author{
SORBUS.
}

POMACEE.

ICOSANDRIA TRIGYNIA.

French, sorbier ; Italian, sorbo.

The Service tree, Sorbus Domestica, is called in French, Alizerer, in Italian, Bagolaro, Loto. From which last name it is suspected to be the Lotus of the Romans, especially as it seems to agree with the description given by Pliny (Hist. Nat. 13, 1\%, ) of that tree. It is of a middle size; its growth is very slow, and it attains a great age before it produces any blossom. The leaves are pinnate, and alternate; the leaflets of which they are composed are opposite, and vary in number from six to nine pairs, with an odd one at the extremity. The blossoms are of the colour of country cream; the fruit pearshaped, of a reddish hue, and spotted; it is harsh to the taste, and not fit for eating until mellowed by frost or time, when it becomes brown and very soft.

This tree has been found wild in some parts of England, and is a native generally of the warmer parts of Europe, where it becomes a much larger and loftier tree than it is here. It flowers in May. The wood is very hard, and is much esteemed for mathematical rules.

The Wild, or Maple-leaved Service, Sorbus Torminatis, French, Alisier Torminale, Italian, Ciavandello, is a rative of England, and many other parts of Europe, 
chiefly in strong soils; it grows forty or fifty feet high, with a large trunk, spreading at the top into a broad head. The blossom is white, and shaped like that of the pear-tree, but smaller. The fruit is shaped like the common haw, but is much larger; it ripens in autumn, and if kept till it is brown and soft has an agreeable flavour. It is sold in the London markets.

The wood is hard, and useful for many purposes.

Like many other plants, their place or name is not determined by botanists; some placing one or other of these trees in the genus Pyrus, some in the genus Cratægus; and others, as Allioni, place the first in the genus Mespilus. The Linnæan botanists do not agree even in what order of the class Icosandria they are to be ranked; some placing one in Icosandria Digynia, the other in Icosandria Pentagynia: others place both in Icosandria Pentagynia. The vacillation thus exhibited by the botanists of the artificial Linnæan school as to the proper place of these plants is an admirable example of the superior merit of the Natural System; as the botanists of that school have constantly placed them in the family of the Pomaceæ. 


\section{SHRUBBY SYRIAN MALLOW.}

\section{HIBISCUS SYRIACUS.}

This shrub is better known among gardeners and nurserymen by its old name of Althæa Frutex. French, ketmie; Italian, chetmia.

This elegant shrub grows six or seven feet high, with many branches. The leaves are large, deeply cut into several divisions, of a cheerful green, and delicate texture. In August appear the flowers, which are mallowshaped, large, and numerous. There are several varieties, differing in the colour of their flowers; one has white flowers, with a purple centre; another has yellow; some have several shades of purple, with white, and a black centre; some of rose colour and white, with a purple centre; and others are finely variegated with all these colours. In mild seasons, there is a succession of flowers till near the end of September.

This shrub is singularly beautiful; it is a native of Syria; is much cultivated in Cochin China; and, for hedges, in Japan. According to Parkinson, it was cultivated in England in 1529; and Martyn observes, that it was probably a new shrub at that time, as he sets it down as tender, to be kept in a large tub or pot, in the house or a warm cellar. Gerarde, in 159\%, speaks of it as a stranger in England; adding, that he has sown the seeds in his garden, and is expecting their success. 


\title{
SPINDLE TREE.
}

\author{
EUONYMUS.
}

"Euonymus," says Martyn, "from the Greek for good name, because the shrub has a had reputation as a poison." French, fusain, or bonnet du prêtre ; Italian, fusaria. We are told that, in Wales, it bears a name which signifies that it is the tree on which the black king of Tartarus undutifully hanged his mother. Why, his black majesty must have been as great a rogue as Nero!

This genus consists of trees and shrubs, of which the younger branches are four-cornered, and the leaves are opposite.

The Common Spindle, or Skewer-wood tree, Euonymus Europaus, when growing in hedges, is a mere shrub; but planted singly, will rise, with a strong woody stem, to the height of twenty feet, or more. The leaves are of a deep green, about three inches long, and one and a quarter broad. About the end of May, or early in June, come out the flowers in bunches, from the sides of the branches; the petals are nearly white, and spread in form of a cross. The fruit ripens in October, at which time the seed-vessels spread open, and expose the seeds, which, being of a beautiful rose-colour, make a fine show.

With the country people this partakes of some of the familiar names of the cornel-tree. The wood is said to be most tough when the shrub is in blossom; and, cut at that time, is used by the watchmakers for cleaning 
watches. It takes the name of bonnet du prêtre, from the form of the seed-vessel; and the seed is peculiar for its being covered with a beautiful scarlet cover, like mace; it is called an arillus by botanists; and when the fruit is nearly ripe becomes exposed by the opening of the outer cover.

The Broad-leaved Spindle tree, Euonymus latifolius, is a native of Austria, Hungary, and most of the southern parts of Europe. It has a stronger stem than the first, and grows to a larger size. The blossoms open white, and afterwards become purple.

The Warted Spindle-tree, Euonymus verrucosus, a native of Austria and Carniola, was cultivated here in 1765 , by Mr. J. Gordon. It flowers in May and June. The stem and branches are warted, whence its specific name.

The Purple-flowered Spindle-tree, Euonymus atropurpureus, is a native of the northern parts of Asia, and is a shrub of six feet. The footstalks and edges of the leaves are tinged with purple. This species was introduced here by Messrs. Kennedy and Lee, in 1756.

The Evergreen Spindle-tree, Euonymus Americanus, was cultivated here by Bishop Compton, in 1713. It grows eight or ten feet high, with many branches, which come out opposite, from the joints of the stem. The leaves are about two inches long, and three-fourths of an inch broad, ending in acute points; they are, as the name implies, green all the year. It flowers in July, but seldom produces ripe fruit in England. 


\title{
SUMACH.
}

\author{
RHUS.
}

Cassuvia.

PENTANDRIA TRIGYNIA.

French, sumac; Italian, sumacho.

There are several species of Sumach in our English plantations, of which the principal are the following.

The Elm-leaved Sumach, Rhus coriaria, French, Sumac d'Europe, Redoul, Roudou, Rouvre des Corroyeurs; Le Vinagrier; Italian, Sommaco, grows about ten feet high; the flowers grow in spikes; they are of a greenish white, and blow in July. This species is a native of the Levant, Italy, Spain, the south of France, \&c. : it was cultivated in the Botanic Garden at Oxford in 1648. The branches are used for tanning leather; and it has been said that Turkey leather is all tanned with this shrub. Ground in a mill, sumach is also used in dyeing, instead of galls. The Tripoli merchants sell the seeds at Aleppo, where they are in common use, to provoke appetite.

The Venice Red, or Silken Sumach, Rhus cotinus, French, Fustet, Coquesigrue; Italian, Scotamo, grows about twelve feet high : the leaves are simple, (in which respect it differs from most of the species, the leaves being generally pinnate,) about two inches long, and the same in width; the flowers are white and numerous; they blow in July. It is a native of many parts of Europe, the Levant and Siberia, and was cultivated by 
Mr. J. Tradescant, junior, in 1656 . 'The wood is used under the name of fustec, young fustick, (to distinguish it from the yellow wood of the Morus tinctoria, or old fustick, for which it is used as a substitute,) as an orange dye,-but the colour is not durable. The bark is used as a substitute for the Peruvian bark in intermittent fever. The leaves are said to fetch a high price in the markets of Spain and Italy, where they are sold to dress Spanish skins, for which they are accounted excellent.

The Virginian Sumach, Rhus typhinum, is a native of North America: the young branches are covered with a soft velvet-like down, resembling that of a stag's horm, both in colour and texture, whence it has vulgarly the name of Stag's-horn tree. The flowers are produced in close tufts at the ends of the branches, in July; and are succeeded by seeds enclosed in purple, woolly, succulent covers, so that these bunches are of a beautiful colour in the autumn.

This species also is used for tanning leather. It was cultivated here in 1629 .

The Scarlet Sumach, Rhus glabrum, is also a North American: it grows in woods, high glades, and old corn-fields. The fruit remains on the shrub all the winter, but the leaves fall early in the autumn. Its height is about nine feet; the blossoms are deep red, as also are the berries, which are used for dyeing that colour: they are very sour; but children eat them with impunity. On cutting the stem, a yellow juice flows from between the bark and the wood; one or two of the outer circles of the stem are white, the innermost of a yellowish green; in the middle is a pith, half an inch or more in diameter, of a brown colour, and so loose that it is easily pushed out with a stick. The branches and berries, 
boiled together, afford a black ink-like tincture. This Sumach was cultivated here in 1726 .

In the same year Mr. Catesby brought from South Carolina the Carolina Sumach, Rhus elegans, of which the blossoms are very numerous, and of a bright red colour; they begin to blow in July, and continue till autumn. The leaves of this species are not pinnate, but are cut into irregular lobes.

Some of the Sumachs are of a poisonous nature, particularly the Rooting Sumach, or Poison Oak, Rhus radicans, and the Varnish Sumach, Rhus vernix, called also the Swamp Sumach, Poison-wood, Poison-tree, or Poison Ash. 'The latter grows in North America, and in Japan; it was cultivated here in 1\%13. The whole shrub is a violent poison, and the poison is communicated by touching or smelling to any part of it. It acts differently upon different persons; indeed some few are not affected by it at all: those who are of an irritable habit, are the most liable to injury from it. It is said that a swarm of bees alighting upon the branches of this $\mathrm{Su}$ mach, were destroyed by the effluvia.

It contains a yellow juice between the wood and bark, which stains linens a dark brown.

Thunberg affirms that the very best Japan varnish is prepared from the Rhus vernix, which grows in great abundance in that country, and is also frequently cultivated for the great profit arising from it. This varnish, which oozes out of the stem when wounded, is obtained from trees of three years old; when it first flows, it is of a lightish colour, and of the consistence of cream, but thickens and blackens on exposure to the air. With this varnish the Japanese cover the posts of their doors and windows, their drawers, chests, cabinets, scimitars, 
fans, cups, soup-dishes, portable-stools, and most articles of their household furniture which are made of wood.

Thunberg tells us also that the candles in that country are made of an oil pressed from the seeds of a species of Sumach. "This oil," says he, "becomes", when concrete, of the consistence of tallow, and is not so hard as wax. The province of Tetsingo more particularly produces this tree, and consequently supplies the greatest quantity of oil. Amongst the presents which the prince from this province brings to the Imperial Court, are one hundred candles of a foot in length, and as thick as a man's arm, with a wick in proportion. These gala candles are burned only twice a-year at court, on particular occasions*."

* Thunberg's Travels in Japan, vol. iii. p. 188. 


\title{
TAMARISK.
}

\author{
TAMARIX.
}

TAMARICINEE.

PENTANDRIA TRIGYNIA.

The French Tamarisk, Tamarix Gallica, is a native of many parts of Europe, of Barbary, Japan, \&c. and naturally grows to a middle-sized tree; here it is seldom more than fifteen or sixteen feet high. The bark is dark brown; the leaves are very narrow, smooth, and bright green; the flowers are produced in taper spikes at the ends of the branches, several growing on one branch; they are about an inch long; the flowers of which they are composed are very small, and closely set; they are of a pale flesh-colour, enlivened by the anthers of bright red; they open in July.

This is an elegant tree, growing generally on the banks of rivers. Dr. Smith observed it growing abundantly in the hedges in Italy, near to the sea; and remarked that the sheep preferred it to any other food, and would touch nothing else while that remained. It has been found wild in some parts of England.

The Tartars and Russians make whip-handles of the wood.

The German Tamarisk, Tamarix Germanica, has many stalks growing from the root; the foliage is more of a grey colour than that of the French Tamarisk; the bark is first a pale green, and then turns to yellow; the flowers are larger than the former, and not so close set. It is a native of many parts of Europe. It was first 
brought into England by Grindall, archbishop of Canterbury, about the year 1558, and at that time was highly esteemed for medicinal purposes.

Evelyn tells us that it was considered of old as one of the unfortunate trees, and under malediction, and therefore used for wreaths to be put round the heads of malefactors. He says, too, that drinking-cans were made of the wood: and it is spoken of as affording brooms to the housewife:

"Amongst the rest the tamariske there stood, For huswives' besomes onely knowne most good."

W, Browne. 


\title{
TRUMPET FLOWER.
}

\author{
BIGNONIA.
}

BIGNONEIE.

WIDYNAMIA ANGIOSPERMIA.

French, bignone; Italian, bignonia.

TH1s genus is superlatively beautiful; it contains trees and shrubs which inhabit the warm climates of the East and West Indies; the flowers are large and handsome, varying in colour according to the species.

The Catalpa tree has already been noticed by its Indian appellation, by which it is best known in the English nurseries.

The Bignonia unguis is from the West Indies; the stems are slender, and require support, to obtain which they stretch forth their tendrils to whatever may grow nearest to them, and by their means fasten themselves firmly. The flowers grow in the wings of the leaves, and are shaped like the fox-glove.

Bignonia Aquinoctialis, like the former, clings to its neighbour by its clasping tendrils. The leaves are of a brilliant green, and remain on all the year. Where they have room, the branches will ramble to a great distance : the flowers are yellow; they are produced at the joints of the stalks. Mr. Miller received this from La Vera Cruz, in New Spain. 
Bignonia rubescens, the Rooting, or Ash-leaved Trumpet flower, French, Jasmin de la Virginie; Italian, Bignonia Florida, grows in the same manner. In Europe, where it is generally planted against walls, it strikes into the mortar, and, so supported, rises to the height of forty or firty feet. The leaves are pinnate, composed of four pairs of leaflets, terminated by an odd one; these are placed in pairs at every joint of the stalks. The flowers are produced at the ends of the shoots of the year, in large bunches; they have long swelling tubes, shaped somewhat like a trumpet, are orange-coloured, and open early in August: this species was cultivated here in 1640 .

The Bignonia sempervirens, or Carolina Yellow Jasmine, which the later botanists call Gelscminum sempervirens, climbs in the same manner as the others. The leaves are green throughout the year; the flowers are trumpet-shaped, and stand erect; they are of a golden yellow, and extremely fragrant. In South Carolina, its native land, it spreads over the hedges, and in the flowering season perfumes the air to a great distance. It grows, but less plentifully, in Virginia also, where it is called Yellow Jasmine.

All the species here mentioned will grow abroad in this country, when they have acquired strength, being protected by mats in frosty weather, and having a little old tanners' bark laid over the roots. The Ash-leaved Bignonia will live without this tender care: this sends out a great many suckers, which may be taken off and planted: these will flower in two or three years. When raised from seed, it will be seven or eight years before it produces flowers. These plants are of long duration: 
Miller speaks of some in full vigour, and producing an abundance of flowers every season, which he knew to be upwards of sixty years old.

The green-house and hot-house boast of many other species of this splendid genus.

Maximilian mentions a variety of Bignonias growing luxuriantly in the woods of Brazil, enlivening them with every variety of colour.

"Several Bignonias overhung the river; they were loaded with large beautiful violet-coloured flowers, which appear before the leaves, and were just opening,-pinkblossomed ones also.

"The Bougainvillæa Brasiliensis twined round the tops of the trees, which were partly without leaves, and covered them all over with its rose-coloured flowers: numerous varieties, also, of Trumpet flowers, some rising high, some creeping on the ground, were growing in the greatest luxuriance; adorned with every variety of rosecoloured, violet, white, and yellow blossoms.

"This beautiful Bougainvillæa, and Bignonias, covered with a profusion of gold-coloured blossoms the dark tops of the loftiest trees."

Again, he describes " a forest of old colossal trees, as Mimosas, Lignum Vitæ, and Bignonias, \&c., with parasite plants, as Passiflora, Bauhinia, Banisteria, \&c.; the climbing stems of which were rooted in the ground, while their leaves and flowers occupy only the highest summits of their supporters; so that they cannot be examined without cutting down one of those gigantic monarchs of the forest*."

* Maximilian's Brazil. 
Trees are sometimes so strongly fastened, and, as it were, netted in these twining shrubs, that they will not fall, though a number of them should be cut. Sometimes they bind the trees so tightly as to destroy them; but oftentimes they will give protection to the trees that support them; and, as Mr. Drummond observes, it is probable they may on many occasions prevent their being overthrown by storms*.

" Pale blue, and bright violet bindweeds grow luxuriantly and interlace each other. We were particularly struck with a splendid shrub which has a very close affinity with the Trumpet flower, with large bright red blossoms, which glowed like fire in the dark shade. We soon came to a large forest : lofty, slender, white-barked mimosas, cecropias, cocoas, and other trees, were here so closely interwoven with innumerable creeping plants, that the whole seemed to form one impenetrable mass. In the dark summits of the trees, the flowers of the Bignonia Bellas (so called after the Marchioness de Bellas, who first discovered this beautiful plant) glowed like firet."

Mr. Drummond quotes a passage from Cook's Voyages, which well exemplifies the support returned to the trees by these slender parasites.

" On the $1 \%$ th we spent the forenoon in cutting down a number of very tall trees, of which we wished to gather the flowers, but all our efforts were in vain. We had no sooner cut a tree, than it hung in a thousand bindweeds

* Drummond's First Steps to Botany.

+ Maximilian's Brazil. 
and climbers from top to bottom, from which it was not in our power to disengage it*."

Had the Bignonias been Europeans, we should, doubtless, have found their beauty celebrated in various tongues.

* Forster's Voyages, vol. i. p. 506. (New Zealand.) 


\section{TULIP TREE.}

\section{LIRIODENDRUM.}

The botanical name signifies lily tree; the tree bearing liliaceous flowers. It is called by our English gardeners tulip tree. French, tulipier ; Italian, tulipifero.

THE Tulip tree, Liriodendrum tulipifera, is a native of North America, where it grows to a great size, and is generally known in the English settlements by the title of Poplar. When it was first brought to this country, and for some time afterwards, it was planted in pots, and housed in winter with myrtles, oranges, \&c. from a notion that it could not bear the open air ; and thus treated, it grew but slowly: the first tree of the kind which bore flowers here was in the gardens of the Earl of Peterborough, at Parson's Green, near Fulham. It was there planted among other trees in a wilderness; and by the great progress it made, soon convinced the gardeners of their mistake in treating it so tenderly. From that time, they have been planted abroad, where they grow to a considerable size, especially where the soil is rather moist. This tree at Parson's Green has afforded much knowledge to the gardeners, as well in its death as in its life; for though planted in the open air, the neighbouring trees were suffered to overhang it, to shelter it from the wind; these trees robbed it of its nourishment, and in the end destroyed it. 
The leaves of the Tulip tree are of a singular form, being divided into three lobes, of which the middle one is blunt, and hollowed at the point, as if cut with scissars ; the leaf is about four inches long, and about the same width near the base; the foot-stalk is of much the same length. A strong midrib runs from the footstalk along the leaf, from which branch several smaller veins, and these again break into more minute ramifications. The upper surface of the leaf is smooth, and of a fine lucid green ; beneath, their colour is much paler. The fiowers, which are produced at the ends of the branches, are composed of six petals, three without, and three within, forming a sort of bell-shaped flower; whence the inhabitants of North America gave it the title of Tulip. These flowers are marked with green, yellow, and red spots, and when the trees are in full flower, they have a very handsome appearance. The blossoms open in July, and when they fall, are succeeded by a kind of cone, which does not ripen in England.

Kalm observes, that it is very pleasant at the end of May to see one of these large trees with its singular leaves, covered for a fortnight together with flowers which have the shape, size, and partly the colour of Tulips. The wood is used for canoes (whence the Swedes resident in North America call it Canoe tree), for bowls, dishes, and spoons. This author mentions a barn which he saw, of considerable size, the sides and roof of which were formed of one Tulip tree, split into boards : but he says this wood is subject to one great inconvenience, for that it contracts and expands itself more than any other. The bark is pounded, and given as a medicine to horses. The roots are supposed to be a good substitute for jesuits' bark in cases of ague. 
Mr. Marshall describes this tree as seventy or eighty feet high; and Catesby says some of them are thirty feet in circumference in America, and that the timber is used in New England for periagues; the trunk being large enough to be hollowed out into those boats, which are made of one piece, and will carry a number of men.

"This is," says Martyn, " a tree of extraordinary beauty and stateliness, and highly deserves a place in all noble and elegant plantations."

The Oriental Tulip tree, L. lilifera, is a smaller tree, with a blossom of nine petals, a native of China. 


\title{
TUPELO TREE.
}

\author{
NYSSA.
}

Named Nyssa, from a water nymph, on account of its growing in the water.

The Mountain Tupelo tree, or Sour Gum, a native of Pennsylvania, was cultivated in this country by the Duke of Argyll, in 1750. It will grow as high as forty feet, with a trunk two feet in diameter. The leaves are of a dark lucid green on the upper surface; paler, and somewhat hairy underneath; those of the male tree are generally much narrower than those of the female, or fruit-bearing tree. The timber is close-grained and curled, so that it will not split: it is useful in making carriage-wheels.

The Virginian, or Water Tupelo tree, is a native of the wet swamps of Virginia, Carolina, Florida, \&c. and will grow to the height of an hundred feet. There is a beautiful variety in the foliage of this tree, produced by the downy whiteness of the lower side of the leaves, contrasted by the deep green of the upper side, and the long slender foot-stalks which keep them in continual play. The berries are about the shape and size of small olives; and are preserved, like that fruit, by the French in the neighbourhood of the Mississippi, where the tree 
greatly abounds, and is called the olive tree. The wood, when dry, is light and compact. This species was introduced here by Peter Collinson, Esq. in the year 1735.

These trees will not thrive but in very moist ground. 


\title{
WALNUT TREE.
}

\author{
JUGLANS.
}

JUGLANDE卮.

MONCCIA POLYANDRIA.

Juglans, from Jovis glans, Jove's acorn. French, noyer ; Italian, noce.

The Common IValnut tree, Juglans regia, is not an aboriginal of Europe, nor is its native country accurately known. It has been thought to have come originally from Persia; first to Greece, thence to Italy. It has been found wild in some parts of China. The English name is a corruption of Gaul-nut.

It is a large and lofty tree, with strong spreading branches. The leaves are pinnate, large, smooth, and shining. The blossoms begin to open about the middle of April, and are in full bloom by the middle of May, by which time the leaves are entirely spread. The fruit needs no description. There are several varieties, as the large, the thin-shelled, \&c.

This fruit, unripe, is well known as a pickle ; and it is not likely that the reader should be unacquainted with its ripe kernel.

An oil is obtained from these nuts, which is very useful to artists in white or other delicate colours, and which answers the same medicinal purposes as oil of almonds. In many places, it is used instead of butter, both to eat, and for frying, and is also burned in lamps. The green busks boiled furnish a good dark yellow dye. 
The tree, wounded in the spring, yields a juice, of which a kind of wine is made. Evelyn speaks of one of the sorereigns of Europe in his time, who was said to drink a great quantity of this juice daily, and to derive great benefit from it.

Dr. Clarke tells us that the Tartars pierce the Walnut trees in the spring, when the sap is rising, and put in a spigot for some time; and that when that is withdrawn, a clear sweet liquor flows out, which, when coagulated, they use as sugar*.

In some parts of Italy, France, Germany, and Switzerland, the Walnut is very much cultivated. Burgundy abounds with it; and whenever they fell a tree, says Evelyn, which is only the old and decayed, they always plant a young one near.

In several places in Germany, he tells us, that " no young farmer is permitted to marry till he bring proof that he has planted a stated number of Walnut trees. And the law is inviolably observed to this day, for the extraordinary benefit which this tree affords the inhabitants."

In France and Switzerland, the wood of the Walnut is still in use for furniture, as it was in England until it was superseded by the use of mahogany. At present the Walnut wood is all bought up by the gummakers, for gun-stocks. The latter years of the late convulsions of Europe were peculiarly fatal to the Walnut trees of England. As a good sized tree would produce 600l. and upwards when cut out into stocks, few landholders about London resisted the temptation of this high price, and every tree that was not protected by some legal barrier, 
of a lease or otherwise, fell before the strokes of the axe. The Black Virginian Walnut, however (so called from the black colour of the timber), is far superior for furniture.

" Had we store of this material," says Evelyn, "especially of the Virginian, we should find an incredible improvement in the more stable furniture of our houses. In truth, were this timber in greater plenty among us, we should have far better utensils of all sorts for our houses, as chairs, stools, bedsteads, tables, wainscots, cabinets, \&c. instead of the vulgar beech, subject to the worm, weak, and unsightly."

The shade of the Walnut tree was held by the Romans to be particularly unwholesome. The Black Walnut will not let any thing grow under it; and if planted in an orchard, will kill all the apple trees in its neighbourhood; but the common walnut is more hospitable, and will grow innocently in the midst of corn without hurting the crop. So Evelyn affirms; but Philips does not give it so good a character :

"Or Walnut, whose malignant touch impairs All generous fruits."

The Romans esteemed the wood of the Walnut tree as highly as Evelyn himself could wish. He tells us that he learns from Strabo that tables of it were once even of higher price than those of citron; and that he had seen some planks of it, than which nothing could be more beautiful. It is famed no less for its soundness than the beauty of its grain.

Fairfax speaks of

"The barren platane, and the Walnut sound *."

* Fairfdx's 'Tasso, book 3. st. 76. 
Dodsley, in his poem on Agriculture, refers to the beauty of its grain :

" The sweet-leaved Walnut's undulated grain, Polished with care, adds to the workman's art Its varying beauties."

Evelyn says, that some of the Walnut timber which comes to us from Virginia "is very black of colour, and so admirably streaked, as to represent natural flowers, landscapes, and other fancies."

Cowley has a very curious passage, in which he compares the Walnut to the brain of man. He tells us that its oil nourishes the hair. Indeed he enumerates a variety of uses; and badly as it is translated, its oddity will, perhaps, render it not altogether uninteresting:

"The Walnut, then, approached, more large and tall His fruit, which we a nut, the gods an acorn call :

Jove's acorn, which does no small praise confess To 've called it man's ambrosia had been less.

Nor can this head-like nut, shaped like the brain Within, be said that form by change to gain, Or Caryon called by learned Greeks in vain : For membranes soft as silk her kernel bind, Whereof the inmost is of tenderest kind, Like those which on the brain of man we find; All which are in a seam-joined shell enclosed; Which of this brain the skull may be supposed: This very skull envelop'd is again In a green coat, his pericranium: Lastly, that no objection may remain To thwart her near alliance to the brain, She nourishes the hair, remembering how Herself, deformed, without her leaves does show ; On barren scalps she makes fresh honours grow. 
Her timber is for various uses good;

The carver she supplies with lasting wood:

She makes the painter's fading colours last:

A table she affords us, and repast;

E'en while we feast, her oil our lamp supplies;

The rankest poison by her virtue dies,

The mad dog's foam, and taint of raging skies.

The Pontic king who lived where poisons grew,

Skilful in antidotes, her virtues knew ;

Yet envious fates, that still with merit strive,

And man, ungrateful, from the orchard drive

This sovereign plant; excluded from the field,

Unless some useless nook a station yicld,

Defenceless in the common road she stands,

Exposed to restless war of vulgar hands :

By neighbouring clowns and passing rabble torn,

Battered with stones by boys, and left forlorn."

Cowley's Plants, book v.

Evelyn, speaking of the virtues of the Walnut here recounted by Cowley, goes so far as to say, that if the kernel, being a little masticated, be laid to the bite of a mad dog for three hours, and then cast to poultry, they will die if they eat of it. Of its shade he says, that it has been causelessly defamed; that the scent of the fallen leaves may have proved noxious to some persons, but while fresh, and on the tree, never.

Virgil forms a judgment of the future harvest by the appearance of the Walnut tree in the spring.

"Contemplator item, quum se nux plurima silvis

Induet in florem, et ramos curvabit olentes :

Si superant fœtus, pariter frumenta sequentur.

Magnaque cum magno veniet tritura calore.

At si luxuria foliorum exuberat umbra,

Nequicquam pingues palea teret area culmos."

Georg. i. 
"Observe also when the walnut tree shall put on its bloom plentifully in the woods, and bend down its strong smelling branches: if it abounds in fruit, you will have a like quantity of corn, and a great threshing, with much heat. But if it abounds with a luxuriant shade of leaves, in vain shall your floor thresh the corn, which abounds with nothing but chaff."-(MARTYN's Translation.)

Most of the translators have rendered nux the almond tree; but Martyn has very clearly made it out to be the Walnut tree. If it might be allowed to change two words of Dryden's version, it would remove the error ;

"Mark well the flowering Wainuts in the wood;

If numerous blooms the bearing branches load

The glebe will answer to the sylvan reign,

Great heats will follow, and large crops of grain,

But if a wood of leaves o'ershade the tree,

Such, and so barren will thy harvest be ;

In vain the hind shall vex the threshing floor,

For empty chaff and straw will be thy store."

Walnuts were commonly strewed at the Roman weddings. "This ceremony," says Dr. Hunter, "was to show that the bridegroom had left off all boyish amusements."

Horace speaks of some game played with nuts by the Roman boys, - with nuts and little bones*.

"Postquam te talos, Aule, nucesque

Ferre sinu laxo, donare et ludere vidi."

Satire iii. book 2 .

" You, Aulus, during your childhood, I have observed to carry your bones and nuts carelessly in your bosom, to play them boldly, and make presents of them to your companions."

* A game is still played by schoolboys in France, which they eall osselets, (little bones, in which are used the ankle-bones of sheep, ground square. 
Allusions are frequently made to this nuptial sport, by the poets:

"Let the air with Hymen ring, Hymen, Io Hymen, sing.

Soon the nuts will now be flung:

Soon the wanton verses sung;

Soon the bridegroom will be told

Of the tricks he played of old.

License then his love had got,

But a husband has it not:

Let the air with Hymen ring, IJymen, Io Hymen, sing."

Leigh Hunt, from Catullus.

Herrick has introduced this custom in his Epithalamium on Sir Thomas Southwell and his lady:

"Now bar the door, the bridegroom puts

The eager boys to gather nuts."

A note on this passage says- " The ceremony of throwing nuts at a wedding, for which boys scrambled, was of Athenian origin."

Virgil has an allusion to it in his eighth pastoral:

" tibi ducitur uxor :

Sparge, marite, nuces

" prepare the lights,

O Mopsus! and perform the bridal rites;

Scatter thy nuts among the scrambling boys."

Dryden's Virgil.

Nuts of various kinds made an important figure in the country festivals at Christmas some years back: Spenser alludes to these games in the Shepherd's Calendar for December : 
"I wont to range amid the mazy thicket, And gather nuts to make me Christmas-game. And joyed oft to chase the trembling pricket, Or hunt the heartless hare till she were tame.

What wrecked I of wintry age's wast, Tho' deemed I my spring would ever last.

How of ten have I scaled the craggy oak, All to dislodge the raven of her nest!

How have I wearied with many a stroke The stately walnut tree, the while the rest Under the tree fell all for nuts at strife! For like to me was liberty and life."

Collinson, in his History of Somersetshire, speaking of the Glastonbury thorn, of which it has been said that it always buds on Christmas day, says that there grew also "6 in the abbey churchyard on the north side of St. Joseph's chapel, a miraculous Walnut tree, which never budded forth before the feast of St. Barnabas (that is, the eleventh of June), and on that very day shot forth leaves, and flourished like its usual species. (This tree is gone, and in the place thereof, stands a very fine Walnut tree of the common sort.) It is strange to say how much this tree was sought after by the credulous; and though not an uncommon Walnut, Queen Anne, King James, and many of the nobility of the realm, even when the times of monkish superstition had ceased, gave large sums of money for small cuttings from the original*."

'There is something in the walnut which excites pleasing associations; it makes its appearance, with the wine, after the removal of grosser food; and many an interesting argument, social conversation, and volley of wit and 
laughter, has been carried on with the accompaniment of the nut-crackers. The merely dipping it into the salt, too, gives time to form the joke, prepare the repartee, or parry an adversary's argument.

This delicate nut is enclosed with a care it well deserves.

"Walnut, in rough furrowed coat secure."

Philips.

Evelyn says it is thought better to beat the nuts off, than to gather them from the tree by hand. "In Italy," says he, "they arm the tops of long poles with nails and iron for the purpose, and believe the beating improves the tree, which I no more believe than I do that discipline would reform a shrew."

The Spaniards peel Walnuts that are stale and hard, and grate them over their tarts, cakes, \&c. One bushel of nuts is supposed to yield fifteen pounds of clear, peeled kernels; and from these are obtained half the weight of oil ; the oil is more plentiful when drawn from the fresh nut, but of finer quality if the nut be drier.

Evelyn affirms that an Italian peasant, when he has a pain in the side, drinks a pint of this fresh oil, and finds immediate relief from it. In France, the kernels are cut out of the shells before they are hardened, with a short broad brass knife: these, from the manner of scooping them out, are called cerneaux, and are eaten with wine and salt.

Mrs. Holderness says the Walnut tree is among the most remarkable fruit-trees of the Crimea; that in the valleys of the south coast, it attains to a prodigious size, and forms a most delightful shade around some of the Tartar villages. "I have been confidentially assured," 
continues she, "that a single tree has been known to produce sixty thousand walnuts yearly; and a respectable proprietor of Sudac told me that a tree in his possession bears annually forty thousand*."

Mr. Sass tells us that the road from Milan to the Simplon is bordered, for some distance, with walnut and chestnut trees, and continues through vineyards and plantations of mulberries, to Sesto + " "The Bergstras," says Evelyn, " (which extends from Heidelberg to Darmstadt) is all planted with Walnuts, so as that a man may ride for many miles under a continued arbour, or close walk, refreshed both by their fruit and their shade."

66 How would such public plantations improve the glory and wealth of a nation!" proceeds he: "But where shall we find the spirit among our countrymen? Yes, I will adventure to instance in those plantations of Sir Richard Stidolph, upon the Downs, near Leatherhead, in Surrey, Sir Robert Clayton, at Morden, near Godstone (once belonging to Sir John Evelyn), and so about Cassoulton; where many thousands of these trees do celebrate the industry of the owners, and will certainly reward it with infinite improvement, as I am assured they do already, and that very considerably+."

Although the Walnut is not very dainty in its soil or situation, it is said to prefer the vale to the hill, because better sheltered from keen winds :

"The walnut loving vales says Browne.

* Mrs. Holderness's New Russia, p. 285.

+ Sass's Journey to Rome and Naples, p. 308.

¥ Sylva, vol. i. p. 169 . 


\section{WAYFARING TREE.}

\section{VIBURNUM LANTANA.}

Also called wild Guelder rose. French, camara, mancienne; Italian, lentaggine.

The Lantana is a shrub or small tree, with round, pliant, mealy twigs, whence by some it is called Pliant Mealy tree. The leaves are placed opposite in pairs; they are of a dark-red colour in the autumn, before they fall: the flowers grow in clusters, in botanical language cymes; they are white, and are succeeded by berries which, when young, are red on one side, and yellow on the other; when ripe, they are entirely black.

This tree is a native of all but the most northern parts of Europe; with us, it grows chiefly in woods and hedges, flowering in May. Dr. Withering says, that the bark of the root is used to make bird-lime.

This is generally supposed to be the Viburnum of Virgil, but this is not easily ascertained; his is supposed to be a low shrub, because he contrasts it with the tall cypress. Martyn supposes Viburna, in the plural, to have been used by ancient writers, for any shrubs which were used for binding or tying.

This tree growing plentifully in every corner, affords pins for the yokes of oxen; and superstitious people, thinking that it protects their cattle from being bewitched, place the shrub about their stalls. According to Evelyn, a decoction of the leaves will not only dye the hair black, but will fasten the roots also. 


\title{
WHITE-BEAM TREE.
}

\author{
PYRUS ARIA.
}

YOMACEX.

ICOSANDRIA DIGYNIA.

French, alizier; Italian, aria, sorbo peloso.

THIs tree will grow forty feet high, with a large trunk; the leaves are about three inches long, and half that width; of a light green on the upper surface, but very white on the lower. The flowers grow at the ends of the branches, in bunches or corymbs, two inches or more in diameter: they are white, and are succeeded by red berries.

The White Beam is a native of most parts of Europe, chiefly on dry hills, and sandy exposures, in gravel, clay, or chalk, or from the fissures of limestone rock. With us, it grows in all but the eastern counties.

The wood being hard, tough, and smooth, is made into axle-trees, wheels, walking sticks, and tool handles. The fruit is eatable when mellowed by frost, and an ardent spirit may be distilled from it.

The straight handsome growth of this tree. the smoothness of the bark, the extreme whiteness of the under surface of the leaves, and the handsome bunches of white flowers, succeeded by red berries, render it very desirable as a variety in ornamental plantations.

In Worcestershire, Stafiordshire, Lancashire, and Westmoreland, it is called Red Chess Apple, and Sea Owler; in Derbyshire, Wild Pear tree. Gerarde calls it Cumberland Hawthorn. In some places it is known by the name of White Leaf tree. 


\section{WIDOW-WAIL.}

\section{CNEORUM TRICOCCUM.}

French, camelee : Italian, gneoro : Called also spurge olive.

The Cneorum is a humble shrub, growing in hot, dry, and rocky soils in the south of France, Italy, and Spain. It was cultivated in this country by Gerarde in 1596.

Although of low growth, yet as it is evergreen, bushy, and well furnished with leaves, this shrub is both ornamental and useful in filling up vacancies left near the earth by taller shrubs. The leaves are about an inch and a half long, and a quarter of an inch in the middle; of a dark green, with a strong vein or rib down the middle. The flowers grow from the wings of the leaves, near the extremity of the branches; their colour is a pale yellow; they begin to blow in May, and continue, in mild seasons, even to the end of October. The fruit, which is composed of three seeds joined together like those of euphorbia, is at first green, afterwards brown, and when fully ripe, is quite black.

This shrub was formerly preserved in greenhouses, but has now long sustained our climate in the open ground, and is found to bear it very well, even in the severest seasons, if it be planted in a poor dry soil; but if the ground be moist and rich, the shoots become more luxuriant, and are often injured by hard frosts. 


\title{
WILD CHERRY TREE.
}

\author{
PRUNUS AVIUM.
}

French, merisier; Italian, ciliegio.

The Wild, or Black Cherry, is a native of England ; it grows to a large timber tree, and is very proper to plant in parks, since it is also very beautiful. In spring, when in full blossom, it is particularly ornamental. Birds are as well pleased with the fruit as we are with the blossom ; and while there is fruit to be found, they convert it into a musical bower, where, as long as the sun shines, their cheerful notes are unceasing.

About Polstead, in Suffolk, it grows in abundance, and is there called the Polstead Cherry. In Buckinghamshire, this tree is very much cultivated. In some of the southern counties, the Wild Cherries are called Merries, from the French Merise. The Corone, or Crown, which is an improved variety of this species, is very common in Hertfordshire, and in some parts of Norfolk.

The wood is used for chairs, cabinets, tables, \&c. and for musical instruments, especially the redder sort, which will polish well.

Herrick has a pretty little address to the Cherry blossoms :

"Ye may simper, blush and smile, And perfume the air awhile; 
But, sweet things, ye must begone;

Fruit, ye know, is coming on ;

Then, ah then! where is your grace,

When as cherries come in place?"

Sir W. Ouseley says, that the Turks have the tubes of their pipes, which are from five to seven feet long, made of Cherry wood. 


\title{
WILLOW TRHE.
}

\author{
SALIX.
}

SALICINEA.

DIECIA DIANDRIA.

The word salix expresses quick growth. French, saule; Italian, salcio.

Sort, climate, and situation so greatly influence the Willow, that varieties are multiplied beyond number; many which are but varieties, too, have been divided into distinct species, so that their number is very great. According to some botanists, there are more than fifty British Willows only.

The general appearance of the Willow is well known; and it will suffice to notice such things as are of interest in a few of the species.

The Sweet, or Bay-leaved Willow, Salix pentandria, is much used in Yorkshire for making baskets ; its leaves afford a yellow dye.

Baskets are made from many of the Willows, as well as the Osier, which belongs to this genus; but of the Willows, the Bitter Purple Willow, Salix purpurea, is the best adapted for that purpose, and is used for the finest work.

The Yellow Willow, Salix vitellina, is very common in Russia, and is used at Easter, instead of Palms, in the Greek churches. The down will make tolerable paper, and serve some of the purposes of genuine cotton.

The Common, or White Willow, Salix alba, takes its 
specific name from the white silken surface of the leaves on the under side. The bark is used to tan leather, and to dye yarn of a cinnamon colour. It is one of the trees to which the necessitous Kamtschatdales are often obliged to recur for their daily bread, which they make of the inner bark, ground into flour.

The bark of this Willow has in some cases been found a good substitute for the Peruvian bark.

The Grey Willow, or Sallow, Salix cinerea, grows from six to twelve feet high. In many parts of England, children gather the flowering branches of this tree on Palm Sunday, and call them Palms. With the bark, the inhabitants of the Highlands and the Hebrides tan leather. The wood, which is soft, white, and flexible, is made into handles for hatchets, spades, \&c. It also furnishes shoemakers with their cutting-boards, and whetting-boards to smooth the edges of their knives upon.

The species hitherto mentioned are all Britons; the Weeping Willow, Salix Babylonica, is a native of the Levant ; and, according to horticultural records, was not cultivated in this country till 1790 .

This tree, with its long, slender, pendulous branches, is surely one of the most elegant ornaments of English scenery. The situation which it affects, also, on the margins of brooks or rivers, increases its beauty, of which, like Narcissus, it often seems to bend over the water for the purpose of admiring the reflection:

$$
\text { "___ Shadowy trees, that lean }
$$

So elegantly o'er the water's brim."

The Willows are in general quick of growth; and if the accounts be correct, of the time of the introduction

$$
\text { c } \mathrm{c} 2
$$


of this species into England, this must grow particularly fast, since there are some very fine trees in this country, even in the neighbourhood of London. There is a fine Weeping Willow in a garden near the Paddington end of the New Road, and a most magnificent one, also, in a garden on the banks of the Thames, just beyond Richmond Bridge, on the Richmond side of the river. Several of the arms of this tree are so large, that one of them would in itself form a fine tree. They are propped by a number of stout poles; and the tree appears in a flourishing condition. If that tree be no more than ninety-five years old, the quickness of its growth is indeed astonishing.

Martyn relates an interesting anecdote, which he gives on the authority of the St. James's Chronicle for August 1801 :-

"The famous and admired Weeping Willow planted by Pope, which has lately been felled to the ground, came from Spain, enclosing a present for Lady Suffolk. Mr. Pope was in company when the covering was taken off; he observed that the pieces of stick appeared as if they had some regetation; and added, 'Perhaps they may produce something we have not in England.' Under this idea he planted it in his garden, and it produced the Willow tree that has given birth to so many others."

According to the account before-mentioned, this tree could not have been more than fourteen years old when Pope died. It is said, with what truth the reader must judge, that the destruction of this tree was caused by the eager curiosity of the admirers of the poet, who, by their numbers, so disturbed the quiet, and fatigued the patience of the possessor, with applications to be permitted 
to see this precious relic, that to put an end to the trouble at once and for ever, she gave orders that it should be felled to the ground.

The Weeping Willow is most appropriately named, for, in addition to the pensive drooping appearance of its branches, it is common to see little drops of water, which stand like fallen tears upon the leaves. The willow will grow in any but a dry soil, but most delights and best thrives in the immediate neighbourhood of water. The Willow, in poetical language, commonly introduces a stream, or a forsaken lover :

"Fluminibus salices, crassisque paludibus alni Nascuntur ;"-

says Virgil.

"Willows grow about rivers, and alders in muddy marshes."

"We pass a gulf, in which the willows dip Their pendent boughs, stooping as if to drink."

CoWPER.

Chatterton describes

"The willow, shadowing the bubbling brook."

"Poplars and willows trembling o'er the floods,"

says Pope, in his translation of Homer's Odyssey. It would be pleasant to imagine him sitting under his own Willow as he wrote the line, but that, unfortunately, the Odyssey was published before the tree was planted.

Churchill mentions, among other trees,

"The willow weeping o'er the fatal wave, Where many a lover finds a watery grave; The cypress, sacred held when lovers mourn Their true love snatched away"- 
"Concava vallis erat: qua se demittere rivi Assuerant pluvialis aquæ. Tenet ima lacunæ Lenta salix, ulvæque leves, juncique palustres, Viminaque, et longà parvæ sub arundine cannæ."

Ovid, Met. lib. viii.

"A hollow vale, where watery torrents gush, Sinks in the plain; the osier, and the rush, The marshy sedge, and bending willow nod Their trailing foliage o'er its oozy sod."

Dr. Orger's Ovid.

"Through all, a streamlet from its mountain source, Seen but by stealth, pursued its willowy course."

MONTGOMERY.

"Odours abroad the winds of morning breathe, And fresh with dew the herbage sprang beneath : Down from the hills that gently sloped away To the broad river shining into day, They passed; along the brink the path they kept Where high aloof o'erarching willows wept: Whose silvery foliage glistened in the beam, And floating shadows fringed the chequered stream."

Montgomery.

Virgil remarks the hoary leaf of the Willow :

"Populus, et glauca canentia fronde salicta."

Georgic ii.

Which Martyn renders-

"The poplar, and the willow with hoary bluish leaves."

Shakespeare beautifully describes the scene of Ophelia's death :

"There is a willow grows ascant the brook,

That shows his hoar leaves in the grassy stream;

There with fantastic garlands did she make,

Of crow-flowers, nettles, daisies, and long purples,

That liberal shepherds give a grosser name, 
But our cold maids do deadmen's fingers call them:

There on the pendent boughs her coronet weeds

Clambering to hang, an envious sliver broke;

When down her weedy trophies and herself

Fell in the weeping brook *."

Cowper, speaking of the different hues of trees, says they are

"___ paler some,

And of a wannish gray; the willow such, And poplar that with silver lines his leaf."

"Nor undelightful is the ceaseless hum,

To him who muses through the woods at noon;

Or drowsy shepherd, as he lies reclined,

With half-shut eyes, beneath the floating shade

Of willows grey, close-crowding o'er the brook."

THOMSON.

There are several songs in which despairing lovers call upon the Willow tree :

"Ah, willow! willow !

The willow shall be

A garland for me,

Ah, willow! willow!"

Chatterton has one, of which the burthen runs-

"Mie love ys dedde,

Gon to hys deathe-bedde,

Al under the wyllowe tree."

In the Two Noble Kinsmen, said to have been written by Shakespeare and Fletcher, a young girl, who loses her wit with hopeless love for Palamon,--

"____ She sung

Nothing but 'Willow! willow! willow !' and between Ever was 'Palamon, fair Palamon!"

* Hamlet, Act iv. Scene 7 . 
Shakespeare, in allusion to Dido's being forsaken by Eneas, says-

"In such a night, Stocd Dido, with a willow in her hand,

Upon the wild sea-banks, and waved her love 'To come again to Carthage."

Spenser designates it as

"The willow worn of forlorn paramours."

Herrick thus addresses the Willow tree:

"Thou art to all lost love the best, The only true plant found;

Wherewith young men and maids distrest, And left of love, are crowned.

When once the lover's rose is dead, Or laid aside forlorn ;

Then willow garlands 'bout the head, Bedewed with tears, are worn.

When with neglect, the lover's bane,

Poor maids rewarded be

For their love lost, their only gain

Is but a wreath from thee.

And underneath thy cooling shade,

When weary of the light,

The love-spent youth and love-sick maid

Come to weep out the night."

This poet has some lines addressed to a Willow garland also, which, as his poems are not very readily at hand, may be added :

"A willow garland thou didst send

Perfumed, last day, to me ;

Which did but only this portend,

I was forsook by thee. 
Since so it is, I'll tell thee what:

To-morrow thou shalt see

Me wear the willow, after that

To die upon the tree.

As beasts unto the altars go

With garlands dressed, so I

Will with my willow wreath also

Come forth, and sweetly die."

The Willow seems, from the oldest times, to have been dedicated to grief: under them the children of Israel seem to have lamented their captivity :

"By the rivers of Babylon, there we sat down, yea we wept when we remembered Zion : we hanged our harps upon the willows in the midst thereof."

Psalms.

The ancient Britons used boats made of wicker covered with skins, for passing rivers and arms of the sea :

"Primum cana salix madefacto vimine parvam Texitur in puppim, cæsaque induta juvenca, Vectoris patiens, tumidam superemicat amnem. Sic Venetus, stagnante Pado, fusoque Britannus Navigat oceano."

Lecax, book iv.

"The bending willow into barks they twine, Then line the work with spoils of slaughtered kine; Such are the floats Venetian fishers know, Where in dull marshes stands the settling Po. On such to neighbouring Gaul, allured by gain, The bolder Britons cross the swelling main."

\section{Rowe's Lucall.}

Wicker baskets were made by our forefathers in very early times, for Martial speaks of them :

"Barbara de pictis veni Bascauda Britannis . Sed me jam mavult dicere Roma suam." 
"From Britain's painted sons I came, And basket is my barbarous name. Yet now I am so modish grown, That Rome would claim me for her own*."

The Romans used twigs of Willow to bind their vines: this, and their being used for various sorts of wickerwork, gives occasion to Virgil to notice the twigs it affords, as he speaks of the leaves of the elm with which cattle were fed:

"Viminibus salices foecundæ, frondibus ulmi :"

Georgic ii.

"The willows abound with twigs, the elm with leaves."

MARTYN.

The Spanish poet, Garcilasso, dedicates the Willow to his mistress, which appears rather an equivocal compliment :

"For Daphne's laurel Phœbus gave his voice,

The towering poplar charmed stern Hercules;

The myrtle sweet, whose gifted flowers rejoice

Young hearts in love, did most warm Venus please;

The little green willow is my Flerid's choice,

She gathers it amidst a thousand trees:

Thus laurcl, poplar, and sweet myrtle now, Where'er it grows, shall to the willow bow."

WIFFEN's Garcilasso.

Some of the smallest trees known are Willows; nay, the smallest tree known, without any exception. Several of the species do not exceed a foot in height; but the Herbaceous Willow, Salix herbacea, is seldom higher than three inches, sometimes not more than two; and

* This is a curious instance of the antiquity of the word basket, which may fairly be derived from bascauda. 
yet it is in every respect a tree, notwithstanding the name herbaceous, which, as it has been observed, is inappropriate. Dr. Clarke says, in his Travels in Norway,"6 TVe soon recognised some of our old Lapland acquaintances, such as Betula nana, with its minute leaves, like silver pennies; mountain-birch; and the dwarf alpine species of willow : of which half a dozen trees, with all their branches, leaves, fiowers, and roots, might be compressed within two of the pages of a lady's pocketbook, without coming into contact with each other.

"After our return to England, specimens of the Salix herbacea were given to our friends, which, when framed and glazed, had the appearance of miniature drawings. The author, in collecting them for his herbary, has frequently compressed twenty of these trees between two of the pages of a duodecimo volume. ' Minima', says Linnæus, ' inter omnes arbores est hæc salix.'-6'This willow is the least of all trees*."

The same author observes, that in the great northern forests, he found a species of willow, " that would make a splendid crnament in our English shrubberies, owing to its quick growth, and beautiful appearance. It had much more the appearance of an orange than of a willow tree, its large luxuriant leaves being of the most vivid green colour, splendidly shining. We believed it to be a variety of Salix amygdalina, but it may be a distinct species: it principally flourishes in Westro Bothnia, and we never saw it elsewhere + ."

* Clarke's 'Travels, vol. iii. p. 691.

+ Ibid.p. 254. 


\section{YEW TREE.}

\section{TAXUS BACCATA.}

French, if ; Italian, tasso, libo.

THE Yew tree is a native of Europe, North America, and Japan, particularly in mountainous woods, or the clefts of high calcareous rocks. It is indigenous of England and Scotland, and is supposed formerly to have grown wild in Ireland also, by the numbers found there in a fossil state; but at present there are none but planted Yews growing in that country.

It was a custom with our ancestors to plant Yews near their houses and churches. Dr. Aikin supposes it to have been planted near houses, merely for the absurd purpose of forming it into grotesque figures; the yew being particularly submissive to such treatment. Dr. Hunter says they were placed there, to be at hand for the sturdy bows of our warlike ancestors; "Who drew,

And almost joined the horns of the tough yew."

Both may be right in some degree; they may have furnished bows while bows were in fashion with our warriors, and afterwards have been converted into the figures of which Dr. Aikin speaks. That both these fashions reigned at once, it would be painful to conceive: how grievous, on the eve of a new war, for all the green eagles to be shorn of their wings, the green bulls of their horns, \&c. ! 
Again, for the custom of planting the Yew in churchyards, Dr. Aikin thinks it probable that it was from its being an evergreen, and furnishing boughs for the decoration of churches at Christmas. Yew, however, does not appear to have been commonly used for that purpose. In Brand's Popular Antiquities, the plants chiefly mentioned as adorning churches at the Christmas season are bay, rosemary, holly, ivy, and mistletoe. Cypress is added upon one occasion; and Mr. Brand observes, "In this account, the Cypress is quite a new article; indeed I should as soon have expected to have seen the Yew as the Cypress used on this joyful occasion." The editor gives a note upon this passage, saying that Coles, in his Art of Simpling, affirms that "in some places, the setting up of holly, ivy, rosemary, bays, yew, \&c. in churches at Christmas, is still in use;" and that Parkinson speaks of houses being adorned with box and yew *."

This passage makes it appear that Yew was not very generally used at the Christmas festival; and had a tree been planted in churchyards for that use, it would more probably have been the holly, which was never omitted.

Sir Thomas Browne supposes the planting of Yews in churchyards to derive its origin from ancient funeral rites, being, on account of its perpetual verdure, used as a symbol of the resurrection. Evelyn is of the same opinion.

Dr. Hunter thinks that the best reason to be given for it is, that the branches were often carried in procession on Palm Sunday instead of Palm, and gives an extract

* Brand's Popular Antiquities, 4to. vol. i. p. 408. 
from Caxton's Directions for keeping all the feasts of the year (printed in 1483) as decisive on this point.

"Wherfor holy church this day maketh solemn procession, in mind of the procession that Christ made this day; but for encheson that we have none olive that beareth green leaf, algate therefore we take Yew instead of palm and olive, and bear about in procession; and so is this day called Palm-Sunday."

"As a confirmation of this fact," adds Dr. Hunter, " the Yew trees in the churchyards of East Kent are to this day called palms."

Dr. Trussler supposes the Yew to have been planted in churchyards for the purpose of making bows, and such places particularly chosen, because fenced from cattle. But to this Mr. Brand very justly objects, that other plantations also are fenced from cattle, adding, "Why, too, should there usually be but one Yew tree in each churchyard*?

These were evidently placed near the church for some religious purpose, from the great value set upon a consecrated Yew, in comparison with another Yew tree, in the following list of the comparative value of trees, taken, as Martyn tells us, from the ancient laws of Wales.

$\begin{array}{lllllll}\text { A Consecrated Yew } & - & - & - & £ 1 & 0 & 0 \\ \text { An oak - - } & - & - & - & 0 & 10 & 0 \\ \text { A mistletoe branch - } & - & - & 0 & 5 & 0 \\ \text { A principal oak branch } & - & - & 0 & 2 & 6 \\ \text { A sweet apple tree } & - & - & - & 0 & 5 & 0 \\ \text { A sour apple tree } & - & - & - & 0 & 2 & 6 \\ \text { A Wood Yew Tree } & - & - & - & 0 & 1 & 3 \\ \text { A thorn tree - } & - & - & - & 0 & 0 & 7 \frac{1}{2} \\ \text { Every tree after that - } & - & - & 0 & 0 & 4\end{array}$

* Brand’s Popular Antiquities. 
"Our forefathers," says Martyn, "were particularly careful to preserve this funereal tree, whose branches it was usual to carry in solemn procession to the grave, and afterwards to deposit therein under the bodies of their departed friends. Our learned Ray says, that our ancestors planted the Yew in churchyards, because it was an evergreen tree, as a symbol of that immortality which they hoped and expected for the persons there deposited. For the same reason this and other evergreen trees are even yet carried in funerals, and thrown into the grave with the body; in some parts of England, and in Wales, planted with flowers upon the grave itself *."

Sir Thomas Browne observes, that the Christian custom of decking the coffin with bay is an elegant emblem, because this tree, when apparently dead, has often been known to revive from the root, and to resume its wonted verdure.

From a passage in Shakespeare we might suppose that sprigs of Yew were put within the coffin also.

"My shroud of white, stuck all with yew

O prepare it!"

Blair says, addressing himself to the grave,

"Well do I know thee by thy trusty yew,

Cheerless, unsocial plant, that loves to dwell

'Midst skulls and coffins, epitaphs and worms;

Where light-heeled ghosts, and visionary shades,

Beneath the wan cold moon, (so fame reports),

Embody'd, thick, perform their mystic rounds.

No other merriment, dull tree, is thine."

"The yew, which, in the place of sculptured stone,

Marks out the resting-place of men unknown."

Churchill.

* Martyn's Miller's Dictionary. 
Harte very appropriately places the yew and cypress in the same avenue, leading to the palace of death:

" Dark cypresses the skirting sides adorned, And gloomy yew-trees, which for ever mourned."

Vision of Death.

Sir Walter Scott describes the melancholy appearance of the yew tree:-

"But here 'twixt rock and river grew

A dismal grove of sable yew, With whose sad tints were mingled seen The blighted fir's sepulchral green :

Seemed that the trees their shadows cast The earth that nourished them to blast, For never knew that swarthy grove The verdant hue that fairies love;

Nor wilding green nor woodland flower, Arose within its baleful bower :

The dank and sable earth receives

Its only carpet from the leaves

That, from the withering branches cast, Bestrewed the ground with every blast."

Rokeby, canto ii.

Clorin, in the Faithful Shepherdess, having retired from the world upon the loss of her lover, says .

"___ Yon same dell

O'ertopped with mourning cypress and sad yew, Shall be my cabin; where I'll early rue, Before the sun has kissed this dew away, The hard uncertain chance which fate doth lay Upon this head."

The uncommon pliancy of the Yew, together with its toughness, made it particularly proper for bows; and 
those made of Yew were esteemed superior to every other. The flexibility of this tree is such, that it was considered without a rival for topiary works. Spenser terms it

"The eugh obedient to the bender's will."

In the days of archery, the wood was in such request, that not finding at home a sufficient supply for the bowyers, the merchants were obliged by law to import four staves of it for every ton of goods coming from places whence bow-staves had formerly been brought.

By the fifth of Edward the Fourth, it was directed that every Englishman in Ireland, and Irishman dwelling with Englishmen, should have an English bow of his own height, made of Yew, wych, hazel, ash, or awburne, (supposed to be the alder).

"Formerly," says Mr. Gilpin, "the yew was what the oak is now, the basis of our strength. Of it, the English yeoman made his long-bow, which he vaunted nobody but an Englishman could bend. In shooting, he did not, as in other nations, keep his left hand steady, and draw his bow with the right, but, keeping his hand at rest upon the nerve, he pressed the whole weight of his body into the horns of his bow. Hence arose the English phrase of bending a bow, and the French of drawing one."

The Yew bow was not by any means confined to our ancestors however, though the English bow could be bent only by an Englishman. (Ulysses probably never made the attempt). It is mentioned by Virgil, in his second Georgic :

"Ityræos taxi torquentur in arcus."

". The yews were bent into Ityræan bows."

Martyn observes in a note, that the Ityræi were a people of Cœlo-Syria, famous for shooting with a bow. 
In Harte's Statius, the extraordinary celerity of two youths in the race is expressed by a comparison with the flight of an arrow from a bow of yew :

"Each, like an arrow from the Parthian yew, Sent with full force, along the circus flew."

Spenser tells us that when St. George fought with the dragon, the monster pounced upon, snatched him and his horse from the ground, and

"Long he them bore above the subject plain,

So far as yewen bow a shaft may send;

Till struggling strong, did him at last constrain

'To let them down before his flightes end."

W. Browne describes it as

" The warlike yewgh by which, more than the lance, The strong-armed English spirits conquer'd France."

Fairfax poetically designates the tree as

"The shooter yew."

Chaucer uses the same epithet.

The Yew has the reputation of being poisonous. Authors differ as to the degree; and so, probably, do the trees themselves. Evelyn endeavours to persuade himself that there is no foundation for this ill opinion of the tree; but he relates some instances recorded of its sins in this way.

Mr. White, in his History of Selbourne, gives several instances in which it has proved fatal to animals; and Dr. Hunter mentions others, equally fatal, of its effects upon the human species. Many others have been told by various writers, ancient and modern. Cæsar, in his Gallic War, relates that Cativulcus, king of the Eburones, killed himself by drinking a draught of Yew. 
Dioscorides says, that a decoction of Yew leaves occasions death.

Old Gerarde says, "The Yew-tree, as Galen reporteth, is of a venomous quality, and against man's nature. Dioscorides writeth, and generally all that heretofore have dealt in the facultie of herbarisme, that the Yew tree is very venomous to be taken inwardly; and that if any doe sleepe under the shadowe thereof, it causeth sicknesse, and oftentimes death. Moreover, they say that the fruit thereof being eaten, is not only dangerous and deadly unto man, but if birds do eat thereof, it causeth them to cast their feathers, and many times to die. All which I dare boldly affirm is altogether untrue; for when I was young and went to schoole, divers of my schcole-fellowes, and likewise myselfe, did eat our fils of the berries of this tree, and have not only slept under the shadow thereof, but among the branches also, without any hurt at all; and that not one time, but many times.

"Daily experience shows it to be true, that the Yew tree in England is not poisonous; yet divers affirme that in Provence in France, and in most hot countries, it hath such a maligne qualitie, that it is not safe to sleepe, or long to rest under the shadowe thereof."

Some believe the leaf to be poisonous, and not the berry. Southey speaks of it in this manner: of the berries he speaks as having eaten them. Regretting some trees that had been felled, he says-

"If he had played about here when a child In that fore-court, and eat the yew berries, And sate in the porch threading the jessamine flowers, Which fell so thick, he had not had the heart To mar all thus."

Of the leaves he gives a different character: 
“6 Sure this is better

Than a great hedge of yew that makes it look All the year round like winter, and for ever Dropping its poisonous leaves from the under boughs, Withered and bare !"

So he takes the opportunity of affording a reasonable argument, both to the friend and the enemy of the tree.

Martyn, in his notes on Virgil, says, "The berries of the yew are said by Pliny to be poisonous. The leaves also, are said by the ancients to be destructive to horses, which we find to be true in England. The berries have been eaten by myself and many others with impunity : but this may be owing to the difference of climate; for Dioscorides, who says it is not alike poisonous in all places, affirms that the berries are poisonous in Italy, and the shade hurtful in Narbonne. Perhaps the species may be different, for there is mention of a sort of Yew in the Pisa garden, which is more bushy than the common, and has leaves more like a fir; and sends forth such a poisonous smell when it is clipped, that the gardeners cannot work at it above half an hour at a time*."

Virgil calls it noxious :

\section{" Taxique nocentes."}

The honey of Corsica is notoriously unwholesome, which Virgil apparently attributes to the bees feeding upon the Yew. He seems to think the Corsican Yew particularly hurtful :

"Sic tua Cyrneas fugiant examina taxos."

Georgic iv.

"So may thy bees avoid the yews of Corsica." 
In the fourth Georgic he desires that there be no Yew trees near their hives:

"Neu propius tectis taxum sine."

Wordsworth speaks of the Yew as rather disagreeable to bees than injurious :

"Nay, traveller! rest. This lovely yew-tree stands

Far from all human dwelling: what if here

No sparkling rivulet spread the verdant herb?

What if these barren boughs the bees not love?

Yet if the wind breathe soft, the curling waves

That break against the shore, shall lull thy mind

By one soft impulse saved from vacancy *."

"Louring in the groves of death,

Yew trees breathe funereal breath."

Harte.

"The resin soft, and solitary yew

For ever dropping with unwholesome dew."

Harte's Statius.

It may be worthy the attention of the humane to consider how far the melancholy character of the Yew may proceed from its solitary life. Dean Swift throws out a hint on this subject which might be turned to advantage. The story of Baucis and Philemon is, doubtless, familiar to the reader. Some writers have affirmed that the hospitable couple were transformed to limes, but the Dean contradicts this assertion :-

" Description would but tire my muse :

In short, they both were turned to yews.

Old Goodman Dobson of the green

* Lines left on a seat in a yew tree, near the Lake of Esthwaite on a desolate part of the shore. 
Remeinbers he the trees has seen;

He'll talk of them from noon till night, And goes with folks to show the sight.

On Sundays, after evening prayer, He gathers all the parish there;

Points out the place of either yew, Here Baucis, there Philemon grew :

Till once a parson of our town,

To mend his barn, cut Baucis down ;

At which 'tis hard to be believed

How much the other tree was grieved, Grew scrubbed, died a-top, was stunted; So the next parson stubbed and burnt it."

It was rather an extravagance, surely, in the pareon to cut down Baucis merely to mend his barn, since the Yew affords a veined wood, very hard and smooth, and valued by turners, inlayers, and cabinet-makers:

" Their beauteous veins the yew

And phyllerea lend, to surface o'er The cabinet."

Mr. Gilpin is a great admirer of the Yew tree, and bitterly resents the manner in which it was so frequently shorn and shivered into all sorts of odd forms. "In a state of nature," says he, "except in exposed situations, it is perhaps one of the most beautiful evergreens we have*".

It is one of the trees mentioned by Virgil as indicating a cold and barren soil.

Although the Yew is of very slow growth, it is a long liver, and some have accordingly grown to an immense bulk. Sereral have been recorded as measuring twenty- 
six feet round the largest part of the trunk. We will pass on to a few of less common magnitude.

Mr. Pennant mentions one in Fotheringal churchyard, in the Highlands, the ruins of which measured fifty-six feet and a half in circumference. Mr. Evelyn speaks of one in the churchyard of Crowhurst, in Surrey, ten yards in circumference; and of another, a superannuated Yew tree in Braburne churchyard in Kent, measuring fifty-eight feet, and eleven inches round; giving a diameter of about six yards and a half.

This author tells an odd story, quoted from Camden, relating to the Yew tree, and the origin of the name of Halifax, that may not be uninteresting.

"One thing more, while I am speaking of this tree: It reminds me of that very odd story I find related by Ir. Camden, of a certain amorous clergyman, that falling in love with a pretty maid, who refused his addresses, cut off her head, which being hung upon a Yew tree till it was quite decayed, the tree was reputed as sacred, not only while the virgin's head hung on it, but as long as the tree itself lasted: to which the people went in pilgrimage, plucking and bearing away branches of it, as an holy relique, whilst there remained any of the trunk; persuading themselves that those small reins and filaments, resembling hairs, between the bark and body of the tree, were the hairs of the rirgin. But what is yet stranger, the resort to this place, then called Houton, a despicable village, occasioned the building of the now famous town of Halifax in Yorkshire, which imports holy hair."

Wordsworth gives an admirable description of some Yews of large size, in which he mentions the extreme slowness of their growth: 
" There is a yew tree, pride of Lorton Vale, Which to this day stands single in the midst Of its own darkness, as it stood of yore, Not loth to furnish weapons in the hands Of Umfraville or Percy, ere they marched To Scotland's heaths, or those that crossed the sfa And drew their sounding bows at Azincour: Perhaps at earlier Cressy, or Poictiers. Of vast circumference, and gloom profound, This solitary tree! a living thing Produced too slowly ever to decay; Of form and aspect too magnificent To be destroyed. But worthier still of note Are those fraternal four of Borrowdale, Joined in one solemn and capacious grove; Huge trunks! and each particular trunk a growth Of intertwisted fibres serpentine, Upcoiling, and inveterately convolved: Nor uninformed with phantasy, and looks That threaten the profane; a pillared shade, Upon whose grassless floor of red-brown hue, By sheddings from the pining umbrage tinged Perennially; - beneath whose sable roof of boughs, as if for festal purpose, decked With unrejoicing berries, ghostly shapes May meet at noon-tide : Fear, and trembling hope, Silence and foresight-death the skeleton, And time the shadow, there to celebrate, As in a natural temple, scattered o'er With altars undisturbed of mossy stone, United worship ; or in mute repose To lie, and listen to the mountain-flood Murmuring from Gleramara's inmost caves."

We cannot do better than conclude with this fine passage from one of the finest poets of our time.

THE END.

Printed by T. Davison, Lombard-street, Whitefriars, London. 


\section{BOOKS JUST PUBLISHED,}

OR

PREPARING FOR PUBIICATION,

By TAYLOR AND HESSEY,

93, FLEET-STREeT, AND 13, WATERLOO-PLACE, PALL MALL.

I.

NEW SERIES OF THE LONDON MAGAZINE.

THE LONDON MAGAZINE and REVIEW, puklished in Monthly Number price $3 s .6 d$. each. The First mber Nuwas published January 1, 1825.

II.

FLCRA DOMESTICA; or the Portable Flower Garden, with Directions for the Treatment of Plants in Pots, and Illustrations from the Works of the Poets. Bro. price $12 s$.

" We are disposed to bestow our warmest commendations on works which, like the Flora Domestica, are adapted to excite an interest in the study of botany, by showing that flowers, as well as quadrupeds and insects, have their biography,their literary as well as their natural history, - their moral character and local attachments, and physical habits, as well as their medicinal virtues. The charm of this rolume lies, however, in the rich poetical illustrations with which the horticultural and botanical remarks are enlirened. These will please all lovers of flowers and lovers of poetry, whether residing in town or country; and the author has shown both taste and industry in selecting and arranging them."'

Eclectic Reriew, October, 1823.

III.

WALLADMOR, "freely translated into German from the English of Sir WaLter Scott," and now freely translated from the German into English. In 2 Vols. post 8ro. Price $16 s$.

IV.

A SHOR'T EXTRACT from the LIFE of GENERAL MINA, Published by Himself. 8ro. $5 s$.

V.

IMAGINARY CONVERSATIONS of LITERARY NEN and STATESHEN. By Walter Savage Landor, Esq. 2 Vols. 8 ro. $1.4 s$.

VI.

A Third Volume of IMAGINARY CONVERSATIONS of LITERARY MEN and S'TATESMEN. By Walter Savage Landor, Esq.

VII.

MEMOIRS of the LIFE of FREDERICH SCHILLER: comprehending an Examination of his Works. 1 Vol. 8vo. with a Pertrait. $10 s .6 d$.

VIII.

SCOTTISH SONGS, ANCIENT and MODERN; illustrated with Notes, a Critical Introduction, and Characters of the most eminent Lyric Poets of Scotland. By Allan Cunninguar. 4 Vols. Post 8 ro.

IX.

The ELEMENTS of the DIFFERENTIAL and INTEGRAL CALCULUS. By the Rev. Dionysius Lardner, of the University of Dublin. 8ro.

$\mathrm{X}$.

An ANALY'TICAL TREATISE on PLANE and SPHERICAL TRIGONGMETRY. By the Rev. Dionysius Lardner, of the University of Dublii. 8vo. $\mathrm{XI}$.

The ITINERARY of a TRAVFLLER in the IVILDERNESS ; addressed to those who are performing the same Journey. By Mrs. TAYLor, of Ongar. 
XII.

A SERIES of PLATES, carefully etched after the PAINTINGs and SCULP TURES of the most EMINENT MASTERS of the FLORENTINE SCHOOL, inteuded to illustrate the gradual Advancement of the Arts of Design from the Bcgimning of the 13th to the Close of the 15th Century. By William Yudng Otrley, Esq.

The Work will be published in Imperial Folio, in Monthly Numbers, each containing Six Plates. Price $1 l$. $1 s$.

A very few Copies will be printed on Colombier Paper, to correspond with the large Paper Copies of Mr. OTTLEY'S ITALIAN SCHOOL OF DESIGN. Price 1l. $7 s$. -These, and the smaller Impressions, the first 150 of which will be proofs, will be delivered strictly in the Order of Subscription. No. I. was published on the First of January, 1825. Subscriber's' Names are received by 'Taylor and Hessey.

XIII.

The ITALIAN SCHOOL of DESIGN (containing 84 Plates); being a Series of Nac-Similes of ORIGINAL DRAWINGS, by the most eminent Painters and Sculptors of Italy; with Biographical Notices of the Artists, and Observations on their Works. By William Young Ottuey, Esq. I Vol. super-royal folio, Price 12l. $12 s$. in boards.

A few complete large Paper Copies, in 1 Vol. Colombier folio, may still be had, Price 18 Guineas; or with Proof Impressions of Plates, 24 Guineas.

XIV.

JOURNAL of LLEWELLYN PENROSE, a Seaman. New Edition, will Engravings. 1 Vol. $12 \mathrm{mo}$.

$\mathrm{XV}$.

AIDS to REFLECTION, in a Series of Prudential, Moral, and Spiritual Aphorisms, extracted from the Works of Archbishop Leighton, with Notes and Interpolated Remarks. By S.'T. Coleridge, Esq.

XVI.

ESSAYS and SKETCHES of CHARACTER. By the late Richakd Ayton, Esq. With a Memoir of his Life, and a fine Portrait, engraved by F. C. LEwis, from a Drawing by R. Westall, Esq. R. A.

\section{XVII.}

THE NEW SHEPHERD'S CALENDAR. A Volume of Poems. By JoHN Clare.

\section{XVIII.}

THE PRINCIPAL ROO'TS of the LATIN LANGUAGE, simplified by a Display of their Incorporation into the English 'Tongue, with copious Notes ; forming Part of Mr. Hall's Intellectual System of Education (as explained in a Public Lecture delivereā at Willis's Rooins, on Saturday, 8th of May, 1824), whereby an Adult, previously unacquainted in the slightest Degree with Latin, was enabled, in the short space of only Seven Days, to acquire so considerable a Knowledge of the Latin Language, as to translate, parse, and scan, the whole of the First Book of Virgil's Eneid.

$$
\text { XIX. }
$$

PRECEPT ENFORCED BY EXAMPLE, in the Instructive Letters of Emineut Men to their Youngei Frieuds; interspersed with short Biographs of the Writers. Foolscap Bro.

$$
\text { XX. }
$$

A CRITICAL DISSERTATION on the GOSPEL of St. LUKE, translated from the German of Dr. Frederick Schleiermacher, with an Introduction by the Translator, containing an Account of the Controversy respecting the Origin of the Three First Gospels since Bishop Marsh's Dissertation. 1 Vol. 8vo.

\section{$\mathrm{XXI}$.}

The VISION, or HELL, PURGATORY, and PARADISE, of DANTE ALIGHIERI. Translated hy the Rev. H.F. CARY, A.M. With additional Notes, a Life of Dante, and an lndex. In 3 Vols. 8*o. Price $1 l, 16 s$. in boards. Second Edition. 


\section{Books lately Published by Taylor and Hessey. \\ XXIII.}

The AGAMEMNON of ASCHYLUS, Translated, with Notes, Critical ant Explamitory. By John Symuons, Esq. A.M. of Christ Church, Oxford. 8ro. 8s.

XXIV.

The STAR in the EAST, and other Poems. By Josian Conder. Price 6 .

\section{$\mathrm{XXV}$.}

BATAIIAN ANTHOLOGY, or Specimens of the Dutch Poets, with Remarks on the Poetical Literature and Language of the Netherlands. By JoHn Bowrna, Fisq. and Harny S. Van Drk, Esq. Foolscap 8ro. Price $7 s .6 d$.

XXVI.

The HUMAN HEART, a Series of Tales. By the Author of May You like it. Post 8ro. Price $10 s$. $6 d$.

\section{XXVII.}

LETTERS from MECKLENBURGH and HOLSTEIN, comprising an Accoint of the Free Cities of Hamburgh and Lubeck. Written in the Summer of 1820. By George Downes, A.B. late of Trinity College, Dublin. In 1 Vol 8ro. with three Engravings. Price $10 s .6 d$.

\section{XXVIII.}

SKETCHES of the PRINCIPAL PICTURE GALLERIES in ENGLAND. Foolscap 8ro. Price šs.

\section{XXIX.}

ANCIENT POETRY and ROMANCES of SPAIN. Selected and Translated by John Bowring, Esq. Post 8vo. Price 10 s. $6 d$.

$$
\mathrm{XXX} \text {. }
$$

TOURS to the BRITISH MOUNTAINS, with the Descriptive Poems of Lowther and Emont Vale. By Thomas Wilkinson, of Yanwath, Westmorland. Price8s.6d.

XXXI.

ELIA: ESSAYS which have appeared under that Signature in the LoNDON Magazine. Post 8vo. Price 9.6d.

\section{XXXII.}

CONFESSIONS of an ENGLISH OPIUM EATER. Third Edition. Price $5 s$. XXXIII.

JOURNAL of a TOUR in FRANCE, in the Years 1816 and 1817. By Frances Jane Carey. Zo. Price 14s.

\section{XXXIV.}

POEMS, descriptive of Rural Life and Scenery. By JoHn Clare, a North. amptonshire Peasant. Foolscap 8vo. The Fourth Edition. Price 5s. 6d.

$$
\text { XXXV. }
$$

The VILlage MINSTREL, and other POEMS. By John Clare, with a Fine Portrait of the Author from a Painting by W. Hilton, R.A., and a Slietch of the Author's Cottage. In 2 Vols. foolscap bro. Second Edition. Price $12 s$.

\section{XXXVI.}

TRADITIONAL TALES of the ENGLISH and SCOT'TISH PEASANTRY. By Allan Cunningham. 2 Vols. 12 mo. Price $12 s$.

\section{XXXVII.}

SIR MARMADUKE MAXWELL, a Dramatic Poem: The LEGEND of RICHARD FAULDER, The MERMAID of GALLOWAY, and TWENTY SCOTTISH SONGS. By Allan Cunningham. Second Edition, with Corrections and Additions. 3vo. Price 8s. $6 d$.

\section{XXXVIII.}

A COURSE of PRACTICAL SERMONS, expressly adapted to be read in Families. By the Rev. Harvey MarriotT, Rector of Claverton, and Chaplain to the Right Hon. Lord Kenyon. 3vo. Price 10s. 6d. boards. Third Edition.

\section{XXXIX.}

A SECOND and a THIRD COURSE of PRACTICAL SERNIONS. By the Rev. Harvey Marriott. 8ro. Price 10s.6d. each. 
XL.

HOMILIES for the YOUNG, and more especially for Children of the National Schools. By the Rer. Harvey Marriotr. 12mo. Price $5 s .6 d$. boards.

XLI.

LETTERS on the IIPORTANCE, DLTY, and ADVANTAGES of EARLY RISING. Addressed to Heads of Families, the Man of Business, the Lorer of Nature, the Student, and the Christian. By A. C. Buckland. The Fifth Edition, with an additional Letter and a Preface. In foolscap 8\%o. with a beautiful Frontispiece. Price 6s. boards.

XLII.

IETTERS to au ATTORNEY'S CLERK, containing Directions for his Studies and General Conduct. Designed and Commenced by the late A. C. BuckLand, Author of Letters on Early Rising, and completed by W. H. Bucklavd. Foolscap 8vo. Price $7 s$.

\section{XLIII.}

A LETTER of ADVICE to his GRAND-CHILDREN, Matthew, Gabriel, Anne, Mary, and Frances Hale. By Sir Matthew Hale, Lord Chief Justice in the reign of Charles II. The Second Edition. Printed from an Original Nianuscript, and collated with the Copy in the British Museum. In foolscap 8vo. With a Portrait. Price 5s, boards.

XLIV.

THE COUNSELS of a FATHER, in FOUR LETTERS of SIR MATTHEW HALE to his CHILDREN. In foolscap Evo. with a New Memoir of the Autior, and a fine Portrait. Price $5 s$, in boards. Third Edition.

$$
\text { XLT. }
$$

MA'TERNAL SOLICITUDE for a DAUGHTER'S BEST INTERESTS. By Mrs. TAYlok, of Ongar, with a Frontispiece. Price šs. in buards. Elerenth Edition.

\section{XLVI.}

PRACTICAL HINTS to YOUNG FEMALES, on the Duties of a Wife, a Mother, and a Mistress of a Family. By Mrs. TAYLor, with a Frontispiece. Price $5 s$. in boards. Eleventh Edition.

XLVII.

RECIPROCAL DUTIES of PARENTS and CHILDREN. By Mrs. TAYLOR. With a Frontispiece. Price $5 s$. in boards. Fourth Edition.

\section{XLVIII.}

RETROSPECTION : a Tale. By Mrs. TAy Lor. Foolscap 8vo. with a Frontispiece. Price $6 s$, in boards. Third Edition.

$$
\text { XLIX. }
$$

The FAMILY MANSION: a Tale. By Mrs. TAYLor. With a Frontispiece. Price 5s.6d, in boards. Fourth Edition.

L.

The PRESEN'T of a MISTRESS to a YOUNG SERVANT, consisting of friendly Advice and real Histories. By Mrs. Taylor. With a Frontispiece. Price $3 s .6 \dot{d}$. in boards. Seventh Edition.

LI.

CORRESPONDENCE between a MOTHER and her DAUGHTER at SCHOOL. By Mrs. TAY lor and Miss Taylor. With a Frontispiece. Price $5 s$. in boards. Fifth Edition.

LII.

DISPlaY : a Tale. By Jane Taylor, one of the Author's of Original Poems for Lufant Minds. With a Frontispiece. Price $6 s$, in boards. Tenth Edition.

LiII.

ESSAYS in RHYME, On MORALS and MANNERS. BY JANE TAYLOR, Aithor of Display, \&c. In foolscap 8ro. Price $6 s$. in boards. Fourth Edition. 



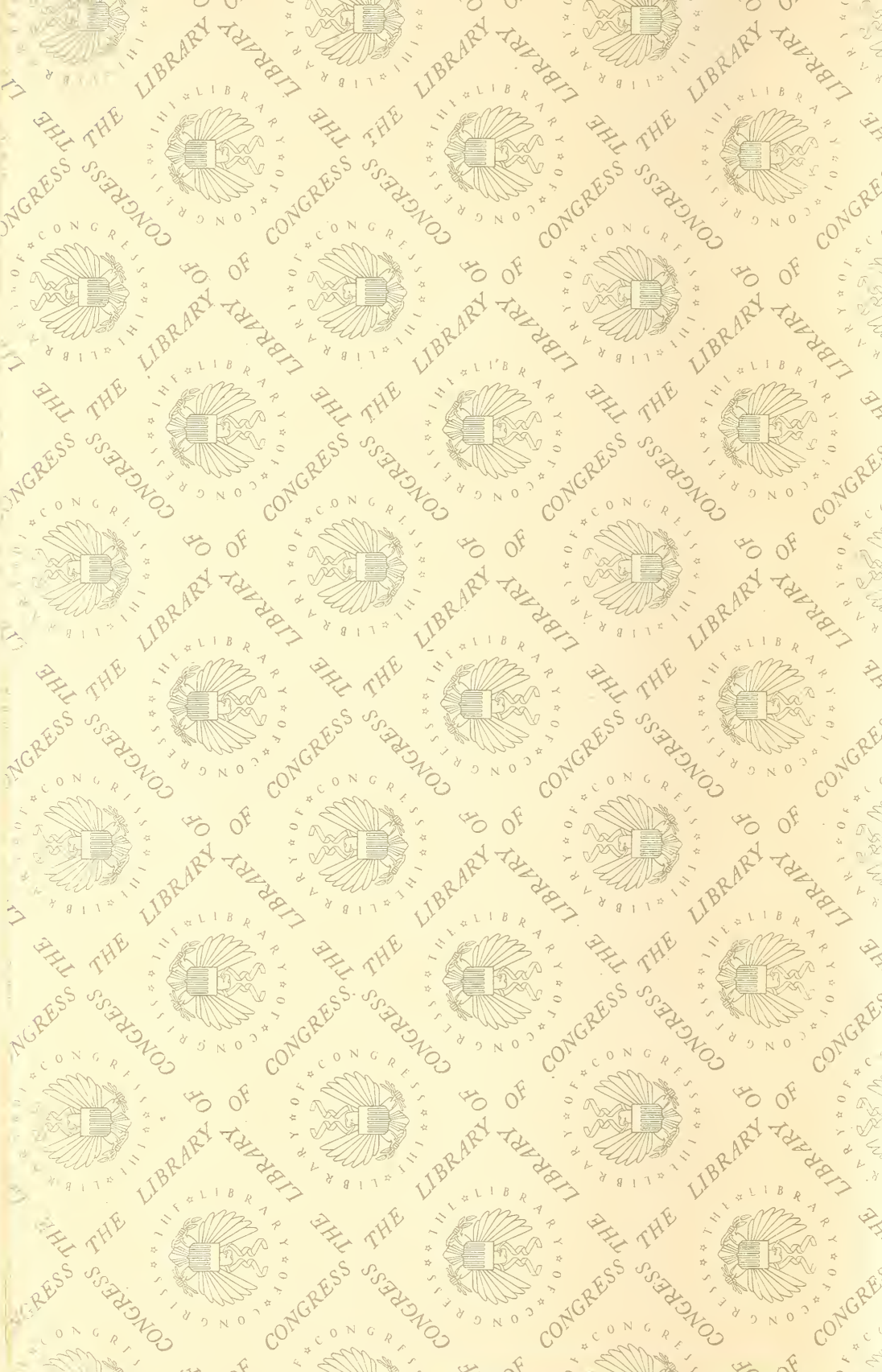


rit

(t)

A

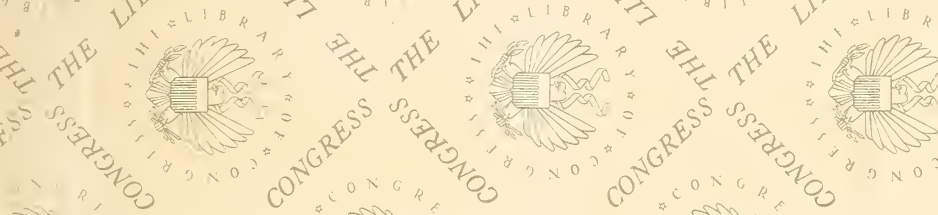

कo of 党 $0^{0}=10^{2}$ की

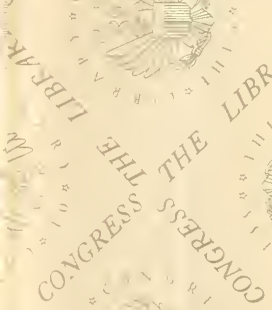<smiles>C1CC2CCC1C2</smiles>

Nen

य० of

$\therefore$ "

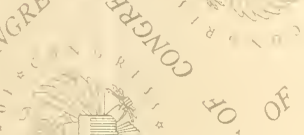

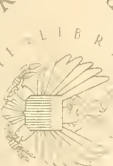<smiles>c1ccccc1</smiles><smiles>[C+]1CC[C@H]2CC[C@H]1C2</smiles>
1 tation $00^{\circ}, \frac{3}{2}$

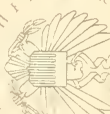

an $c^{\circ}$ o

(n)

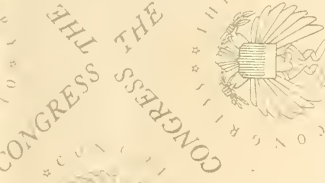

to of<smiles>C1=Cc2cccc1c2</smiles>
(1)

(1)<smiles>c1ccsc1</smiles>

so of

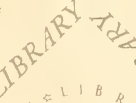
$\frac{0}{20}$ 20 a<smiles>c1ccsc1</smiles>
tyo of पat (a) 供 $\cos ^{5} \mathrm{~s}_{3}$ 
LIBRARY OF CONGRESS

\section{3}

